University of Tennessee Health Science Center

UTHSC Digital Commons

$12-2008$

\title{
Manipulation of the Moloney Murine Leukemia Virus Envelope Protein in an Effort to Develop Directly and Indirectly Targeted Retroviral Vectors for Use in Human Gene Therapy
}

Geneva M. Vasser

University of Tennessee Health Science Center

Follow this and additional works at: https://dc.uthsc.edu/dissertations

Part of the Amino Acids, Peptides, and Proteins Commons, Neoplasms Commons, and the Viruses Commons

\section{Recommended Citation}

Vasser, Geneva M. , "Manipulation of the Moloney Murine Leukemia Virus Envelope Protein in an Effort to Develop Directly and Indirectly Targeted Retroviral Vectors for Use in Human Gene Therapy" (2008).

Theses and Dissertations (ETD). Paper 287. http://dx.doi.org/10.21007/etd.cghs.2008.0336.

This Thesis is brought to you for free and open access by the College of Graduate Health Sciences at UTHSC Digital Commons. It has been accepted for inclusion in Theses and Dissertations (ETD) by an authorized administrator of UTHSC Digital Commons. For more information, please contact jwelch30@uthsc.edu. 


\title{
Manipulation of the Moloney Murine Leukemia Virus Envelope Protein in an Effort to Develop Directly and Indirectly Targeted Retroviral Vectors for Use in Human Gene Therapy
}

\begin{abstract}
Highly effective, targeted therapies against cancer would revolutionize the way people recover from this devastating illness. Gone would be the lingering side effects of the current non-specific treatments and in their place would be faster recovery times, better quality of life both during and after treatment, and less ambiguity about whether or not treatment was effective. This concept will elude modern medicine until treatments can be tailored to the patient's individual and unique disease. This concept of a transient, targeted, and tailored vehicle aimed at cancer cells lends itself to the use of replication deficient retroviral gene therapy vectors with interchangeable receptor binding sites. These vectors may be used separately or in combination with each other to ensure maximum delivery of a suicide gene only to cancerous cells involved with the primary tumor as well as those equally dangerous metastatic cells.
\end{abstract}

Recently, a prototype retroviral vector incorporating the short peptide Somatostatin in place of its natural receptor binding site has been developed. The design of this chimeric envelope protein has the potential to make the insertion of varied receptor binding sites a simple and efficient process. The goal of my studies was to learn more about the potential of this design by taking steps towards challenging its ligand capacity, both in size and secondary structure, and improving its interaction with the target cell.

My studies indicate that the peptide ligand Stromal Derived Factor- $1 \alpha$ (lysine 22 through lysine 89 ) is not a good candidate for use with this chimeric design. They also show that only certain modifications within the Moloney Murine Leukemia Virus heparin binding motif can be tolerated. Supplemental studies point out that (1) the removal of an Mlul site at the CMV promoter N-terminus may enhance promoter function, (2) TransIT (Mirus) is an effective reagent for transfection of DNA into the MDA-MB-231 breast cancer cell line, and (3) a eukaryotic $\alpha$-complementation assay is not sensitive enough to detect cell-cell fusion at levels below that of the wild type MoMLV envelope with its natural receptor. While much investigation remains to be done, these observations will help pave the way to the development of effective retroviral vectors for cancer therapy.

\section{Document Type}

Thesis

Degree Name

Master of Science (MS)

Program

Biomedical Sciences

Research Advisor

Lorraine M. Albritton, Ph.D.

\section{Keywords}

Gene Therepy; Moloney Murine Lukemia Virus; Targeting; Human Breast Cancer; Heparan Binding Site; Mutagenesis

\section{Subject Categories}

Amino Acids, Peptides, and Proteins | Chemicals and Drugs | Diseases | Medicine and Health Sciences | 
Neoplasms | Viruses

This thesis is available at UTHSC Digital Commons: https://dc.uthsc.edu/dissertations/287 
Manipulation of the Moloney Murine Leukemia Virus Envelope Protein in an Effort to Develop Directly and Indirectly Targeted Retroviral Vectors for Use in Human Gene Therapy

\author{
A Thesis \\ Presented for \\ The Graduate Studies Council \\ The University of Tennessee \\ Health Science Center \\ In Partial Fulfillment \\ Of the Requirements for the Degree \\ Master of Science \\ From The University of Tennessee
}

By

Geneva M. Vasser

December 2008 
Copyright (C) 2008 by Geneva M. Vasser

All rights reserved 
For my husband, Stephen W. Dummer, Esq., and our life together...finally. 


\section{Acknowledgements}

Lorraine, thank you for your guidance and friendship. The lessons I've learned under your tutelage will last a lifetime.

Tim, thank you for helping me realize that sometimes it's ok to deviate from the plan. Good luck. You have unlimited free consultations remaining.

Martha and Tiffany, thank you for helping me maintain my perspective.

Family, thank you for your love and support.

The research in this thesis was funded by the following grants to Lorraine M. Albritton: PHS NIH CA81171 and PHS NIH AI33410.

All structural representations were created using the MBT Protein Workshop [1].

All DNA molecule maps were designed using Vector NTI TM Advance 10 Software (Invitrogen, Carlsbad, CA). 


\begin{abstract}
Highly effective, targeted therapies against cancer would revolutionize the way people recover from this devastating illness. Gone would be the lingering side effects of the current non-specific treatments and in their place would be faster recovery times, better quality of life both during and after treatment, and less ambiguity about whether or not treatment was effective. This concept will elude modern medicine until treatments can be tailored to the patient's individual and unique disease. This concept of a transient, targeted, and tailored vehicle aimed at cancer cells lends itself to the use of replication deficient retroviral gene therapy vectors with interchangeable receptor binding sites. These vectors may be used separately or in combination with each other to ensure maximum delivery of a suicide gene only to cancerous cells involved with the primary tumor as well as those equally dangerous metastatic cells.
\end{abstract}

Recently, a prototype retroviral vector incorporating the short peptide Somatostatin in place of its natural receptor binding site has been developed. The design of this chimeric envelope protein has the potential to make the insertion of varied receptor binding sites a simple and efficient process. The goal of my studies was to learn more about the potential of this design by taking steps towards challenging its ligand capacity, both in size and secondary structure, and improving its interaction with the target cell.

My studies indicate that the peptide ligand Stromal Derived Factor-1 $\alpha$ (lysine 22 through lysine 89) is not a good candidate for use with this chimeric design. They also show that only certain modifications within the Moloney Murine Leukemia Virus heparin binding motif can be tolerated. Supplemental studies point out that (1) the removal of an MluI site at the CMV promoter N-terminus may enhance promoter function, (2) TransIT (Mirus) is an effective reagent for transfection of DNA into the MDA-MB-231 breast cancer cell line, and (3) a eukaryotic $\alpha$-complementation assay is not sensitive enough to detect cell-cell fusion at levels below that of the wild type MoMLV envelope with its natural receptor. While much investigation remains to be done, these observations will help pave the way to the development of effective retroviral vectors for cancer therapy. 


\section{Table of Contents}

Chapter 1. Introduction........................................................................................................ 1

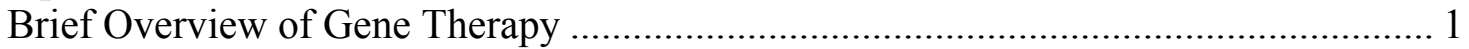

Moloney Murine Leukemia Virus as a Retroviral Vector ............................................... 2

Gene Therapy as Treatment for Cancer .................................................................... 6

Chapter 2. Materials and Methods..................................................................... 7

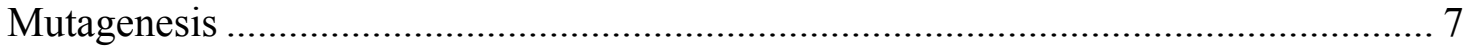

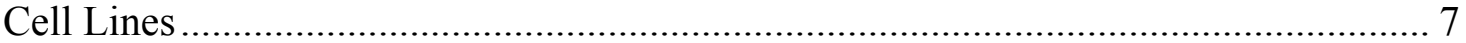

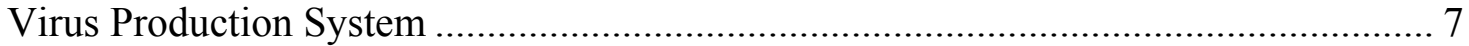

Two-Plasmid System of Retroviral Virus Production.............................................. 9

Three-Plasmid System of Retroviral Virus Production............................................... 9

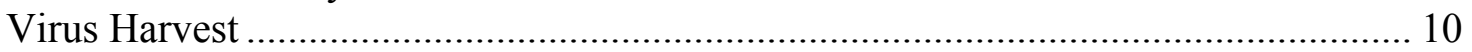

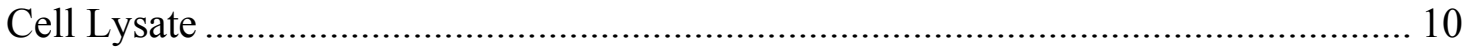

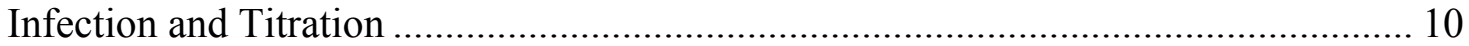

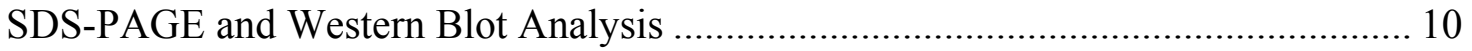

\section{Chapter 3. Investigation of the Impact Replacing the Putative MoMLV Receptor} Binding Site with a Large Ligand Has on Envelope Expression and Infection ........ 12

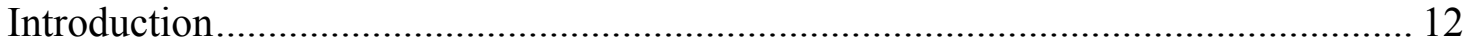

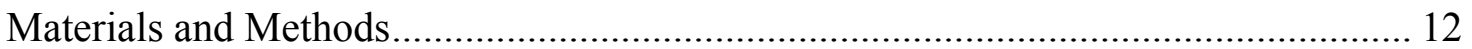

Construction of Plasmids for SDF-1 $\alpha$ /RBS Chimeras.............................................. 12

Cell Lines and Receptor Plasmid Construction. ................................................... 15

Flow Cytometry. ....................................................................................... 15

Virus Production, Infection, and Titration......................................................... 15

SDS-PAGE and Western Blot Analysis. ........................................................... 17

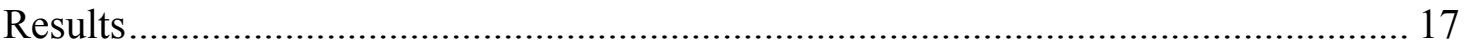

Design of SDF-1 $\alpha$ Constructs. ............................................................................. 17

The Chimeric SDF-1 $\alpha /$ RBS Proteins Were Not Expressed Well on Viral Particles. 18 SDF-1 $\alpha /$ RBS Virus Did Not Effectively Transduce 293 Cells Transiently

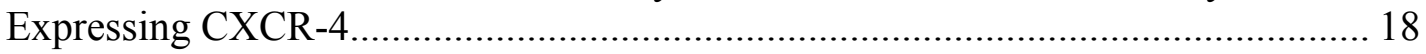

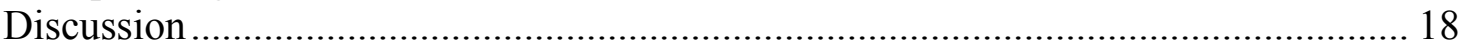

Chapter 4. Mutational Analysis of the MoMLV Heparin Binding Site....................... 25

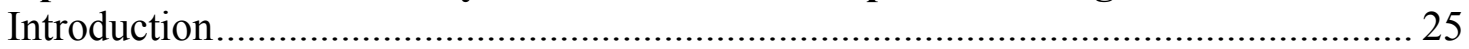

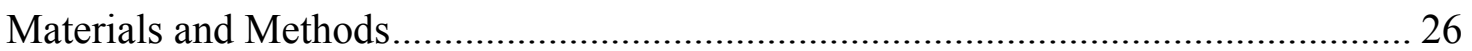

Construction of Heparin Binding Site Mutant Plasmids......................................... 26

Cell Lines, Virus Production, Infection, and Titration........................................... 26

SDS-PAGE and Western Blot Analysis. ............................................................ 29

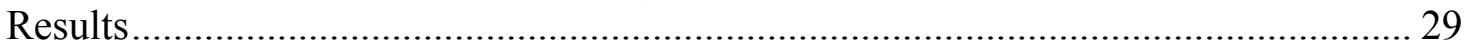

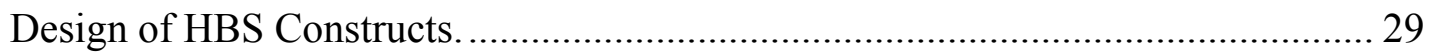

HBS Mutations 4, 5, 7, and 8 Impede MoMLV Envelope Cleavage. ....................... 31

HBS Mutant Envelope Proteins 1, 2, 3, and 6 Influence Syncytia Formation.......... 31

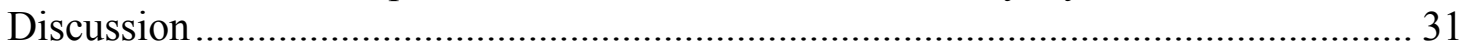


Chapter 5. Discussion ............................................................................................................ 37

List of References ................................................................................................................... 40

Appendix A. Supplemental Plasmids ................................................................................ 49

GV-1 through 5. Sst/RBS Stabilization .............................................................. 49

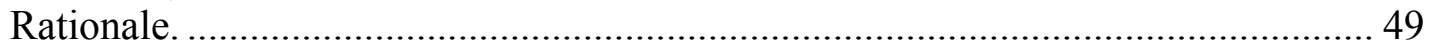

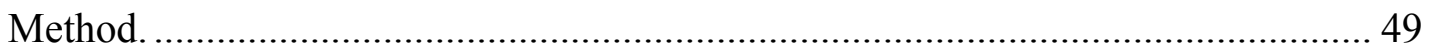

GV-6. 3240 Plasmid Envelope Protein Reduction ………........................................ 49

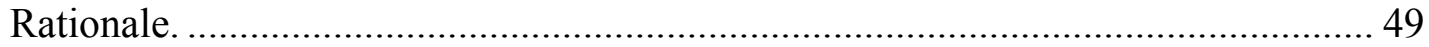

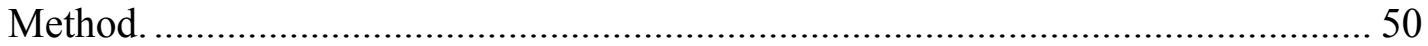

GVTS45 and GV752. Removal of the MluI Site in the pcDNA3_delNeo Plasmid

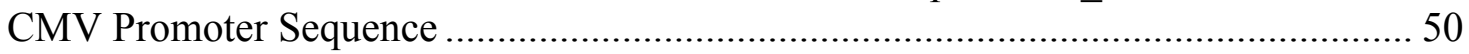

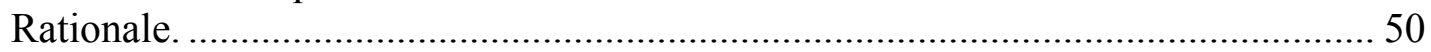

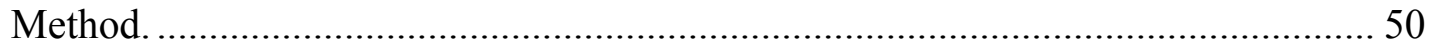

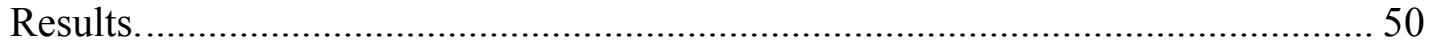

Appendix B. Fusion Assay........................................................................................... 52

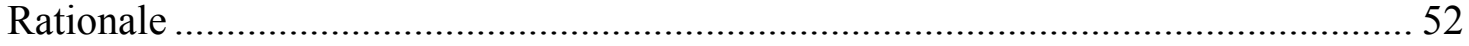

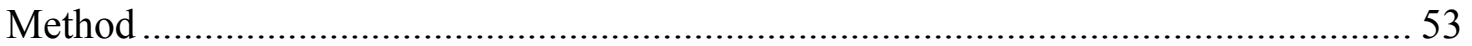

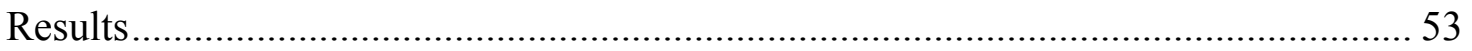

Appendix C. Plasmids............................................................................................................... 60

Vita 


\section{List of Tables}

Table 3-1. Table of Oligos Used to Produce and Identify SDF-1a/RBS and Related Constructs. .......................................................................................... 13

Table 3-2. PCR Mutagenesis Parameters Used to Create SDF-1 $\alpha$ Vectors and Amplify the SDF-1 $\alpha$ Insert. .................................................................. 14

Table 3-3. Alignment of SDF-1 $\alpha$ and SDF-1 $\alpha /$ RBS Protein Sequences ..................... 16

Table 4-1. Table of Oligonucleotides Used in the Production of HBS Mutation Constructs 1 through 8 ........................................................................ 27

Table 4-2. $\quad$ PCR Mutagenesis Parameters Used to Create SDF- $1 \alpha$ Vectors and Amplify the SDF-1 $\alpha$ Insert. .................................................................... 28

Table 4-3. Alignment of the Amino Acid Sequence of the Putative Heparin Binding Sites in Wild Type and Mutant Envelope Proteins................................. 30

Table B-1. Transfection Optimization......................................................................... 54

Table C-1. Plasmids Constructed and Used. ............................................................... 60 


\section{List of Figures}

Figure 1-1. Schematic Representation of the MLV Envelope Protein. ......................... 4

Figure 1-2. Structural Representation of FrMLV RBD.......................................... 5

Figure 2-1. Schematic Representation of ExSite Mutagenesis Oligonucleotides.......... 8

Figure 3-1. Western Blot Analysis of Viral Pellets Produced in BES-buffered DMEM and $\beta$-Me DMEM. .

Figure 3-2. SDF-1 $\alpha /$ RBS Infection in Unaltered DMEM and BES-buffered DMEM. 20

Figure 3-3. Western Blot Analysis of Viral Pellets Produced in DMEM and BESbuffered DMEM. ............................................................................... 21

Figure 3-4. Double Envelope SDF-1 $\alpha /$ RBS Infection in DMEM............................... 22

Figure 3-5. Effect of Doubling the SDF-1 $\alpha /$ RBD Plasmid Mass during Virus Production. ..................................................................................... 23

Figure 4-1. Western Blot Analysis of HBS Mutant Proteins................................... 32

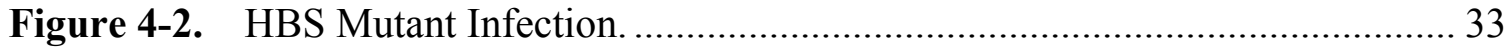

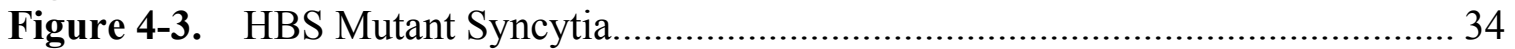

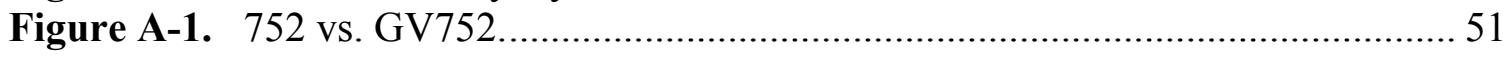

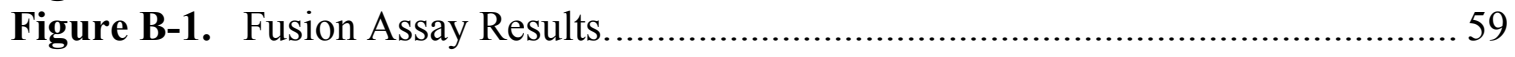

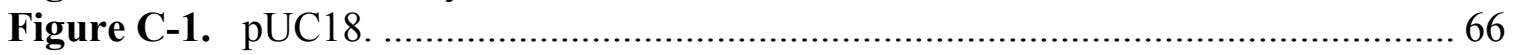

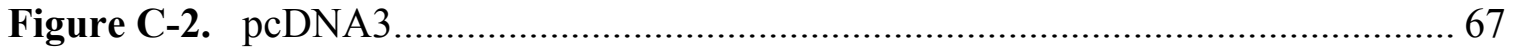

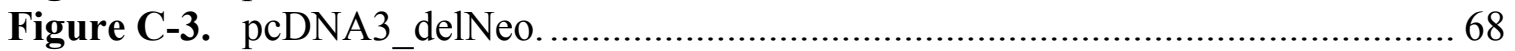

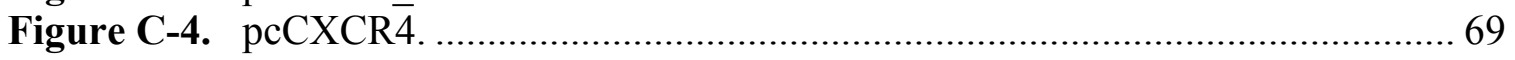

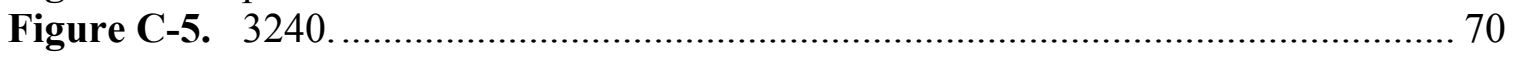

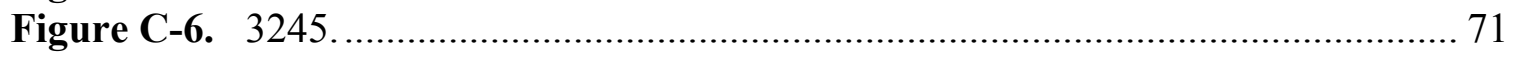

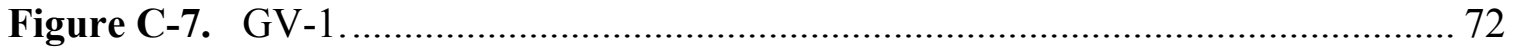

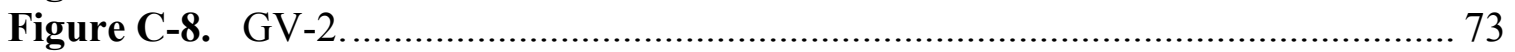

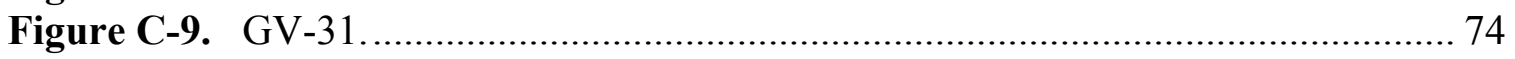

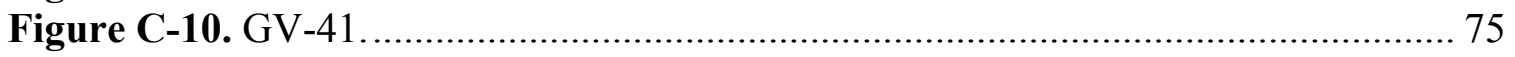

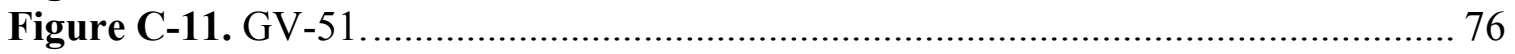

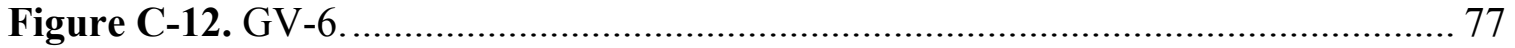

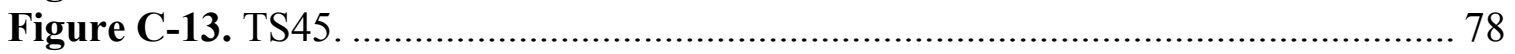

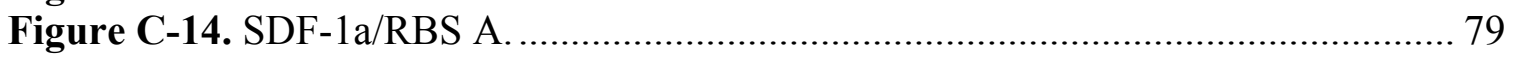

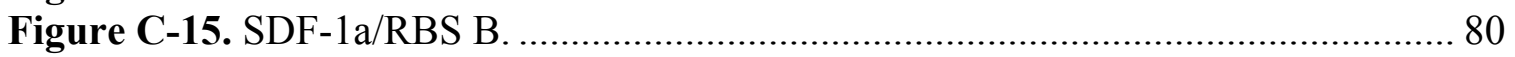

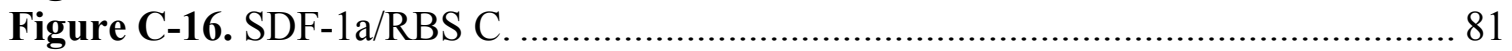

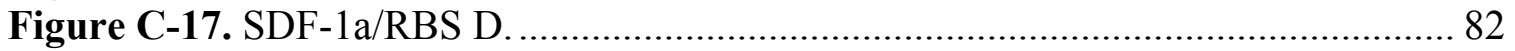

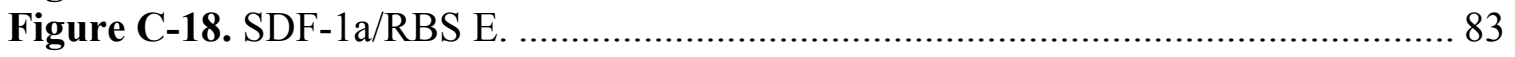

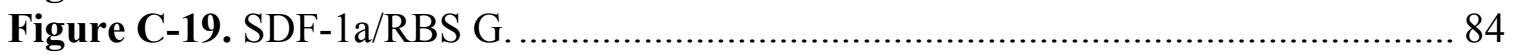

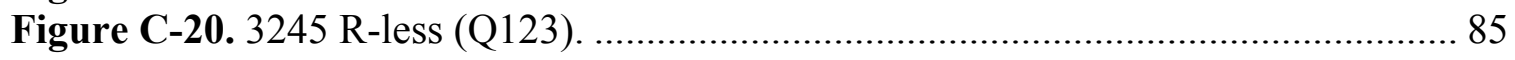

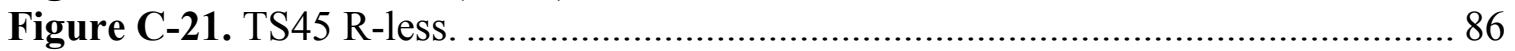

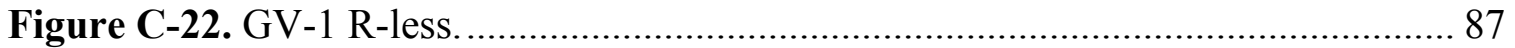

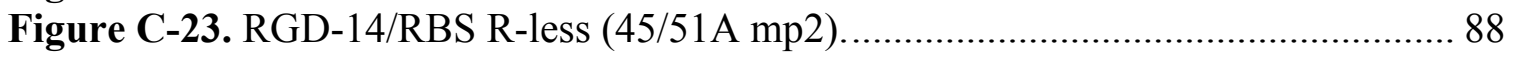

Figure C-24. Cys-Bombesin-1/RBS R-less (45/67 mp2). ..................................... 89

Figure C-25. Cys-Bombesin-2/RBS R-less (45/68 mp2). ........................................ 90

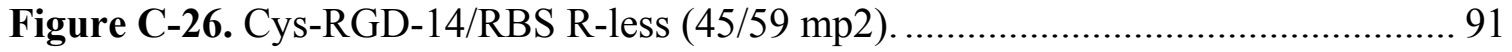

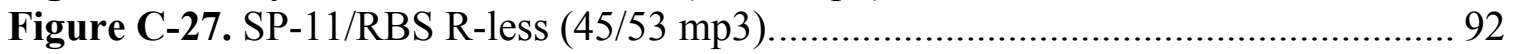


Figure C-28. Neurotensin/RBS R-less (45/54 mp3) ………................................... 93

Figure C-29. Oxytocin/RBS R-less (45/49 mp3)................................................. 94

Figure C-30. Bombesin/RBS R-less (45/56-5 mp3) ............................................. 95

Figure C-31. Endothelin-1/RBS R-less (45/50 mp3). ............................................ 96

Figure C-32. TS45_delRBS R-less (45/39-4b mp2) ................................................. 97

Figure C-33. TS45_delRBS............................................................................ 98

Figure C-34. GVTS45

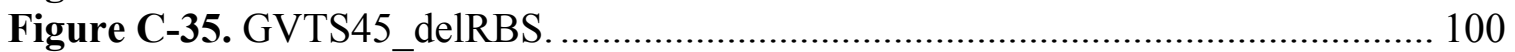

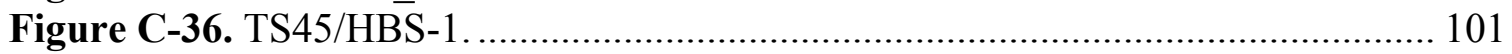

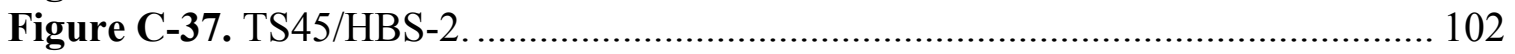

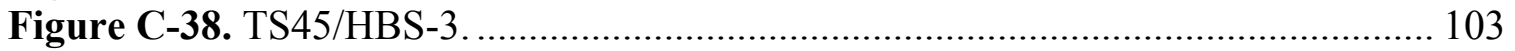

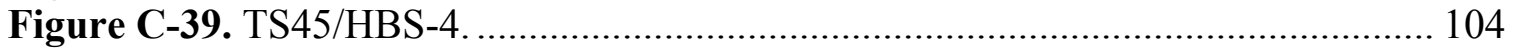

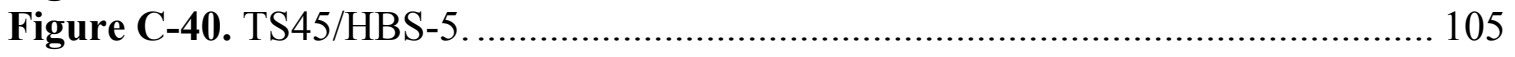

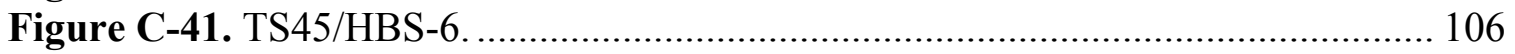

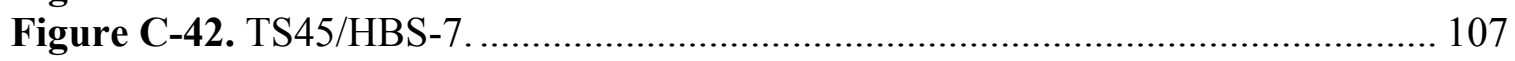

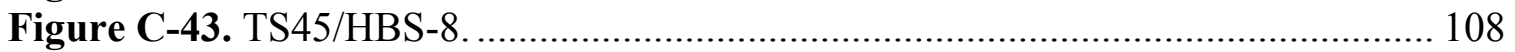

Figure C-44. 752 .

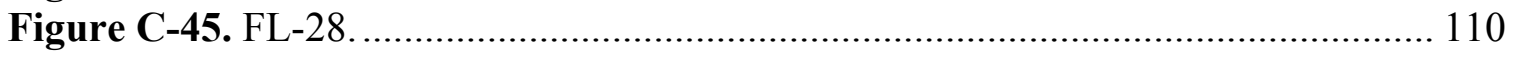

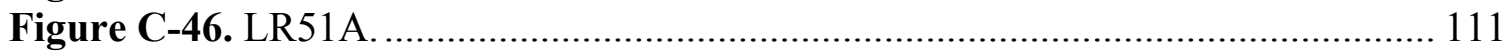

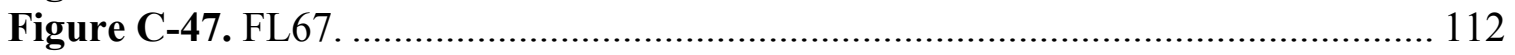

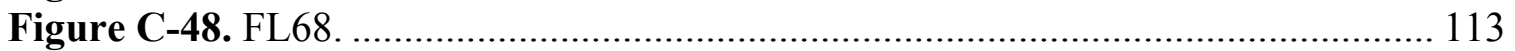

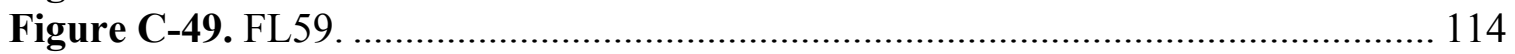

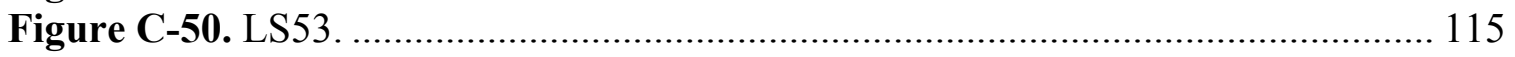

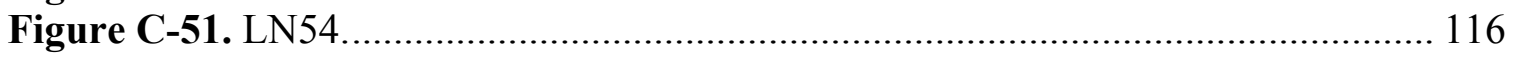

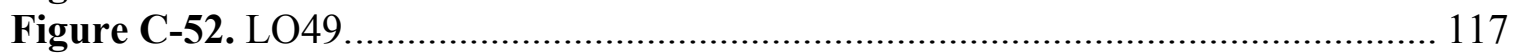

Figure C-53. LB56-5

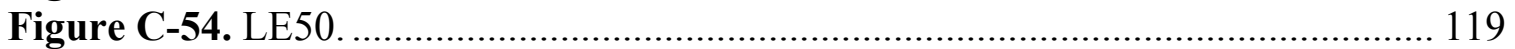

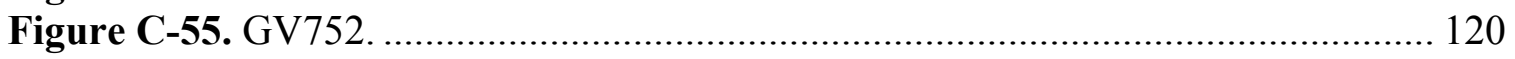

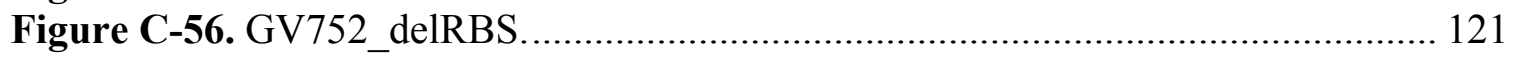

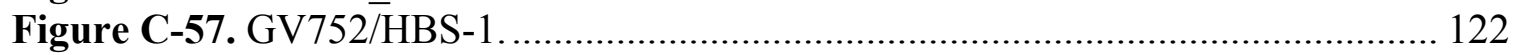

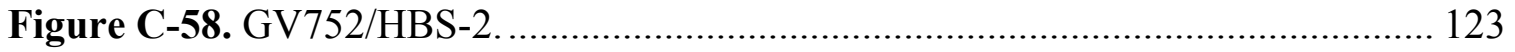

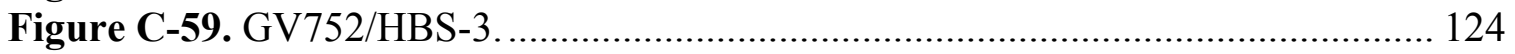

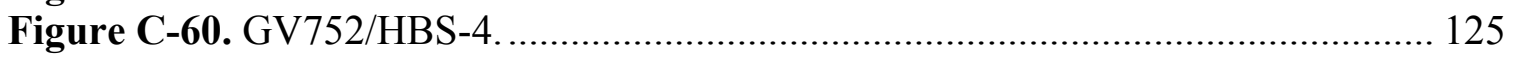

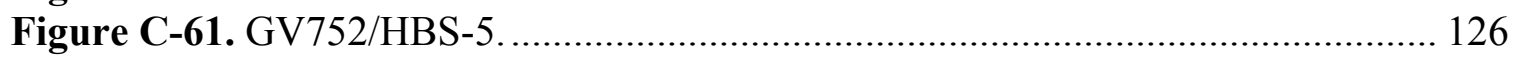

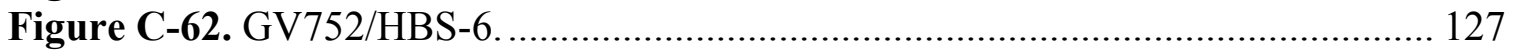

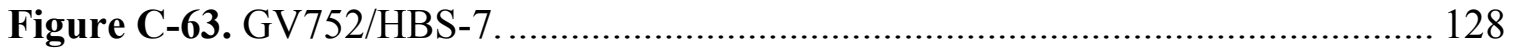

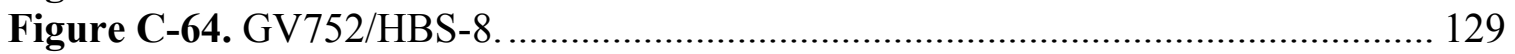

Figure C-65. GV752_delRBS/HBS-1 .......................................................... 130

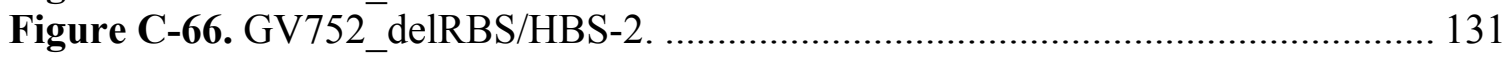

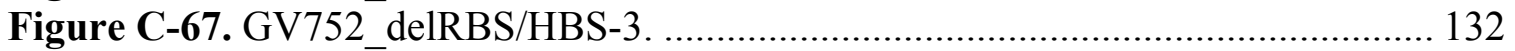

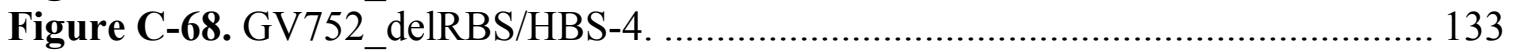

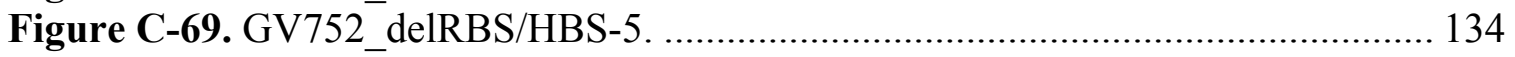

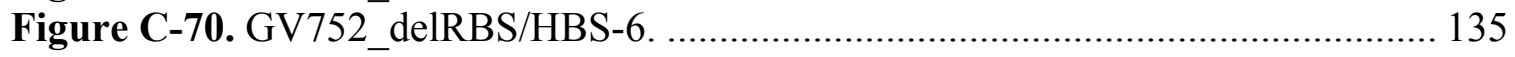

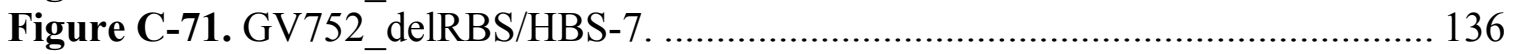

Figure C-72. GV752_delRBS/HBS-8. ................................................................. 137 


\section{Chapter 1. Introduction}

\section{Brief Overview of Gene Therapy}

It has long been conceived that genetic defects may be repaired by the delivery of a gene that can effectively produce a protein allowing cells to function normally or, as in the case of cancer therapies, results in tumor cell death. This concept is known as gene therapy and faces several hindrances that must be considered before any gene may successfully be delivered. First, the host immune system presents several barriers occurring at different stages of gene delivery. Not only will the vehicle or vector itself likely be immunogenic, but any new gene product may also elicit an unfavorable immune response. Further challenges are presented by the need to deliver a gene into a specific cell and expression of this new protein at levels required to produce a therapeutic effect.

Although several methods have successfully been utilized to deliver genes to cells ex vivo, there are very few viable options for in vivo gene therapy. Gene therapy using retroviral vectors was conceived in the early 1980's and has demonstrated a considerable success rate in clinical trials of ex vivo gene delivery to progenitor cells of the bone marrow [2-5]. The family Retroviridae is divided into two subfamilies, Orthoretrovirinae and Spumavirinae. The subfamily Orthoretrovirinae is further broken down into six types: Alpharetrovirus (prototypically represented by the Avian Leukosis Virus, ALV), Betaretrovirus (Mouse Mammary Tumor Virus, MMTV), Gammaretrovirus (Murine Leukemia Virus, MLV), Deltaretrovirus (Bovine Leukemia Virus, BLV), Epislonretrovirus (Walleye Dermal Sarcoma Virus, WDSV), and Lentivirus (Human Immunodeficiency Virus Type I, HIV-1), which are defined by their method of host cell entry.

The retroviral genome consists of two positively oriented, single strands of RNA. The alpha-, beta-, and gammaretroviruses have simple genomes coding for only the main structural and enzymatic genes gag, pol, and env while the others have complex genomes which include non-structural accessory genes which affect pathogenesis and/or gene expression of viral proteins. Retroviruses attach to their host cell using their surface protein which undergoes conformational changes that mediate host cell and virion membrane fusion thus allowing transfer of the viral core to the host cell cytoplasm. It is from within this viral core that the viral reverse transcriptase transcribes the genome from RNA to DNA. These two strands of DNA come together end to end and are coupled with the viral integrase to form a linear preintegration complex which either traverses the nuclear membrane, as in the case of lentiviruses, or takes advantage of the nuclear breakdown during cell division to be inserted into the host cell genome. This integrated genome is called the provirus and consists of the viral genome flanked by long terminal repeats (LTRs) made up of unique 3' and 5' regions and a repeat region duplicated during the reverse transcription process. This provirus is then transcribed by the host cell RNA polymerase II into full length RNA transcripts which are either transported as messenger RNA (mRNA) into the cytoplasm or spliced within the nucleus to create mRNA for the envelope polyprotein and then transported into the cytoplasm. In the cytoplasm, the full 
length mRNA are first translated into precursor polyproteins, Gag and Gag-Pol, which are cleaved into the various structural (capsid, matrix, nucleocapsid) and enzymatic (protease, reverse transcriptase, integrase) proteins necessary for particle production and then, as particles become available, are packaged as viral genomes with the protease, reverse transcriptase, and integrase proteins. The envelope mRNA is directed to the endoplasmic reticulium where it is translated and processed. This process will be further discussed in the next section.

\section{Moloney Murine Leukemia Virus as a Retroviral Vector}

The MLV group or viruses consists of several subtypes which differ in host range: amphotropic, ecotropic, polytropic, xenotropic, and 10A1, based on their receptor preference [6]. Moloney Murine Leukemia Virus (MoMLV), an ecotropic MLV, has been a key player in the quest to develop an effective vector for gene therapy [7] and has been studied extensively in an effort to overcome the difficulty presented in targeting these vectors to specific cell types. MoMLV offers a unique starting point in the sense that its host range does not extend beyond the rodent cells which express its receptor, a cationic amino acid transporter known by several different names (Slc7a1, ATRC-1, mCAT-1, Rec-1, and Rev-1). Homologs of this receptor are present in other species, but do not serve as ecotropic MLV receptors due to sequence variation in the virus binding site [8-11]. Three receptor residues have been shown to provide the most critical contribution to virus binding: lysine 234, tyrosine 235 and glutamic acid 237, only the first residue of which is conserved in the amino acid transporter of non-rodent species $[10,12]$. Therefore it is unlikely humans will have previously been exposed to this virus and have developed defenses against it.

Although many attempts at targeting using chimeric MoMLV virions have been made in the past and some reports of success have been made, none of these claims have been substantiated by other investigators and this goal remains unachieved [13]. Many of these attempts have, however, answered critical questions. First and foremost, the question of MoMLV host range expansion was addressed and it was discovered that expansions are possible through mutations and insertions made in the surface (SU) subunit of the MoMLV envelope protein [14-21]. Furthermore, any mutations or additions in this region must be made in such a way as not to disturb the structural integrity and thus the function of this protein [22-31].

Retroviral envelope mRNA is derived from an alternative splicing event which removes the gag and pol genes as discussed earlier. The resulting mRNA is translated in the endoplasmic reticulum where the resulting proteins associate as trimers which are transported to the Golgi for glycosylation and furin-like protease cleavage into two portions: the SU subunit mentioned in the above paragraph and the transmembrane (TM) subunit which are linked by disulfide bonds [32]. Cleavage of SU from TM is not a prerequisite for the production of infectious viral particles [33]. TM is further cleaved by the viral protease to activate fusion after budding occurs [34-37]. The MLV SU consists of a receptor binding domain $(\mathrm{RBD})$, a hypervariable proline rich region (PRR), and a C- 
terminal domain (CTD). The MLV RBD has been determined to include three variable regions responsible for its variance in receptor tropism, termed variable regions $A, B$, and $\mathrm{C}$ (VRA, VRB, and VRC); within those regions are hydrophilic loops created by disulfide bonds that also affect receptor binding [38-43]. Once SU binds its receptor, it undergoes conformational changes which expose the fusion peptide and allow transfer of the viral genome from the endosome into the host cell cytoplasm [44]. Figure 1-1 shows a schematic representation of the MLV envelope protein.

Extensive genetic analysis of the MoMLV RBD has revealed the receptor binding sequences within it. Aspartic acid $84\left(\mathrm{D}_{84}\right)$ is the most important residue involved in virus binding to its natural receptor and the fourteen residue disulphide-bonded loop containing $\mathrm{D}_{84}$ is thought to be the receptor binding sequence (RBS). A $\mathrm{D}_{84}$ changed to lysine $\left(\mathrm{D}_{84} \mathrm{~K}\right)$ mutation is the only known single change in the envelope protein that completely abrogates virus binding to the natural receptor $[42,45]$. Virions bearing a $\mathrm{D}_{84} \mathrm{~K}$ mutated envelope are non-infectious [42], but infection can be rescued fully by using a receptor with a complementary lysine 234 to aspartic acid $\left(\mathrm{K}_{234} \mathrm{D}\right)$ change [12], supporting the thought that the RBS lies within the disulfide-bonded loop from residues 72 - 85 (numbered from the mature N-terminus of the MoMLV envelope protein).

In our research group, Ryu and coworkers showed that while insertion of the peptide ligand IL-13 sequence into the amino-terminus (N-terminus) or the PRR of SU did not give infection, the reason for loss of function differed with the position of the insertion [31]. Insertion in the $\mathrm{N}$-terminus blocked entry immediately after virus binding whereas the PRR insertion blocked entry after membrane fusion began, after exposure of the fusion peptide but before stable fusion pores were formed. These authors proposed that one way to overcome these blocks to entry would be to use a new design for modifying the MoMLV envelope protein in which the natural RBS, those specific residues that contact the natural receptor during virus attachment, was replaced by a peptide ligand sequence.

To test their proposal, two of these authors (L. Albritton and F. Li) replaced the RBS with somatostatin (Sst), a short peptide structurally homologous to the RBS sequence [46]. To accomplish this, amino acids 72 through 85 were first replaced by a RBS deletion sequence consisting of a tyrosine-alanine-serine (YAS) linker sequence termed del RBS which encodes at its center an MluI site. The Sst peptide was synthesized with flanking MluI linkers and inserted into the del RBS sequence. This chimeric virus infected human 293 cells expressing the type 2 somatostatin receptor (SstR2), a Gcoupled protein receptor, at titers greater than $2 \times 10^{4}$ lac $Z$ transducing units per milliliter (TU/ml) while control 293 cells lacking the SstR2 cDNA were not infected and murine $\mathrm{NIH} 3 \mathrm{~T} 3$ cells were infected at titers of less than $10 \mathrm{TU} / \mathrm{ml}$ (unpublished observation). Thus, their data supported their hypothesis that virions carrying the chimeric Sst/RBS envelope protein are the first truly targeted MoMLV-based vector.

It is commonly accepted that the readily available crystal structure of the Friend Murine Leukemia Virus (FrMLV) RBD (RBD (Protein Database (PDB) accession number 1AOL) [43,47] (Figure 1-2) accurately represents the MoMLV RBD, the 
SU

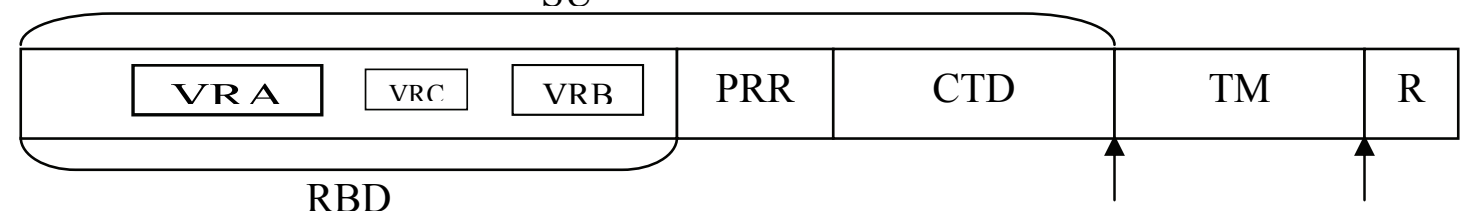

Figure 1-1. Schematic Representation of the MLV Envelope Protein. The Murine Leukemia Virus (MLV) envelope protein is made up of two parts, a surface (SU) and a transmembrane (TM) subunit, which are separated by furin-like protease cleavage during their transit through the host cell Golgi. The TM domain is further cleaved by the viral protease after budding has occurred removing the small p2E or R-peptide and allowing for fusion peptide activation. The SU subunit is made up of three domains: the receptor binding domain or RBD, the proline rich region or PRR, and the C-terminal domain or $\mathrm{CTD}$. The RBD has been empirically determined to consist of three regions influencing virus receptor binding and attachment: variable regions (VR) A, B, and C. 


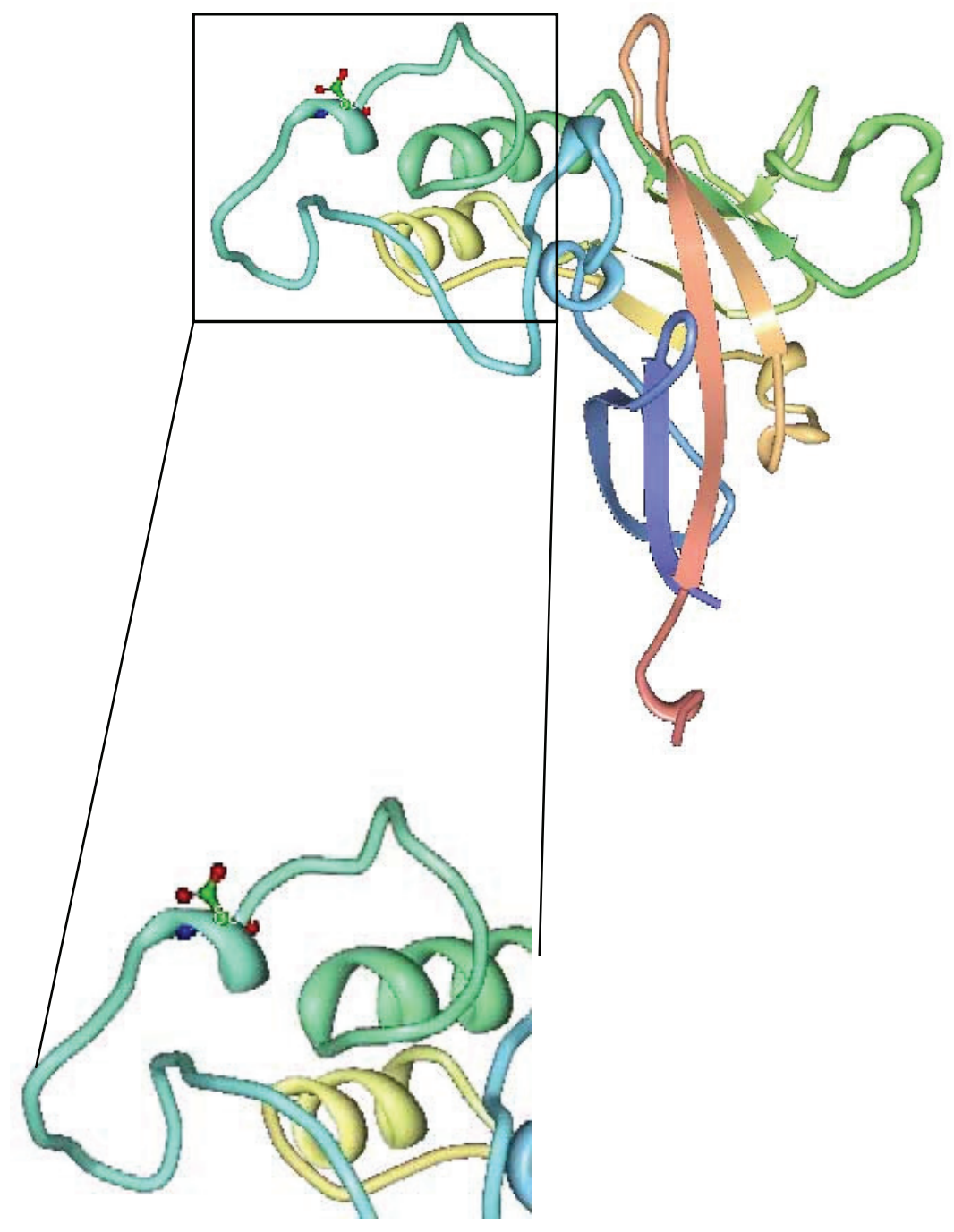

Figure 1-2. Structural Representation of FrMLV RBD. Ribbon diagram of the FrMLV RBD (Protein Database (PDB) accession number 1AOL) and an enlarged view of the portion of RBD containing the fourteen amino acid residues replaced in the Sst chimera. This representation was interpreted by the Molecular Biology Toolkit (MBT) Protein Workshop. The FrMLV D ${ }_{86}$ amino acid which corresponds to MoMLV $\mathrm{D}_{84}$ is indicated in both panels as a ball and stick model. 
rationale being that both MoMLV and FrMLV utilize the same receptor for binding and to trigger entry as well as having highly homologous amino acid sequences. All structural considerations during these studies were based on this assumption.

\section{Gene Therapy as Treatment for Cancer}

In addition to its usefulness as a therapeutic vehicle for genetic diseases, gene therapy may also be used to destroy cancerous cells via delivery of suicide genes designed to either increase cell susceptibility to radiation [48], activate cell death upon encountering a particular drug [49], or repair damaged cell death mechanisms [50]. The efficacy of gene therapy as cancer treatment depends on several factors, but importantly on the ability to target cancerous cells for gene delivery. Without targeting, the concept of treating cancer in this way would be no less destructive to the human body than the current treatments of radiation, chemotherapy, and surgery [51] which damage normal tissues throughout the body to different extents. For example, radiation and chemotherapy affect actively dividing cells and cause side effects such as hair loss, gastrointestinal distress, and fatigue $[52,53]$. Additionally, excision boundaries extended into known normal tissue during surgical removal of tumors could potentially be made more exact through visualization of cancerous cells using fluorescent or luminescent protein expression. There is room for improvement in the area of cancer treatment and targeted therapies are one way to achieve this goal.

The phenotypic diversity of breast tumors continues to present a formidable challenge in identifying the most effective therapeutic combination for each patient and mortality remains unacceptably high despite many advances in the field. Viral vectors designed using the method employed to create the Sst/RBS chimera have the potential benefit of rapid interchangeability between peptide ligands allowing for a more patient-specific approach to treatment as well as the added ability to deliver a combination of virions targeting different receptors on the same breast cancer cells, thus enhancing delivery while avoiding competition. Because the pre-integration complex of integase and the reverse transcribed viral cDNA requires breakdown of the nuclear envelope to access the host genome, use of the parent virus MoMLV as an anti-cancer agent would afford similar levels of specificity to chemotherapy and radiation. We hope to improve upon this current limitation of MoMLV by developing vectors that mediate infection in a cancer-specific fashion directly through the use of receptors that are known to be upregulated on cancer cells and indirectly through increased attachment to the heparan coats cancer cells produce. It is our belief that the combination of these two attributes will serve to increase specificity towards cancerous cells and lessen normal tissue damage during treatment. 


\section{Chapter 2. Materials and Methods}

\section{Mutagenesis}

Mutations were generated using QuikChange (Stratagene) to introduce mutations that encompassed one or two nucleotide changes or ExSite (Stratagene) to introduce large stretches (up to approximately seventy nucleotides) of mutated sequence.

Oligonucleotides for mutagenesis using the QuikChange protocol were homologous to at least eighteen nucleotides of the flanking sequence on either side of the mutation site. Oligonucleotides for mutagenesis using ExSite oligos were designed as indicated in Figure 2-1. The forward oligonucleotide consisted of sequence both homologous (directly following the sequence to be mutated) and non homologous (spanning the sequence to be mutated) to the template. The reverse oligonucleotide was entirely homologous to the template sequence immediately preceding the sequence to be mutated. However, one chimeric envelope protein described in Chapter 3 (SDF-1 $\alpha /$ RBS G) was constructed using a modification of the protocol in which both the forward and reverse oligonucleotides were designed to introduce a collective sixty-four nucleotides of mutated sequence. Polymerase Chain Reaction (PCR) parameters are outlined in Chapters 3 and 4 for each construct. Following PCR mutagenesis and amplification, all products were self-ligated by addition of T4 DNA ligase (New England Biolabs), and individual products were propagated in either the E. coli Top $10 \mathrm{~F}^{\prime}$ or DH5- $\alpha$ strain.

\section{Cell Lines}

The NIH 3 T3 mouse fibroblast cell line was maintained in Dulbecco's Modified Eagle's Medium (DMEM) supplemented with 8\% donor calf serum (DCS). The 293 human embryonic kidney cell line and all cell lines derived from 293 cells were maintained in DMEM supplemented with $8 \%$ fetal bovine serum (FBS) during the receptor binding site (RBS) studies. During the heparin binding site (HBS) studies, the H1-BAG cell line was maintained in DMEM supplemented with 8\% Fetalplex Animal Serum Complex (Gemini BioProducts). H1-BAG is a stable packaging cell line developed via calcium phosphate co-precipitation transfection of 293 cells with the pBAG plasmid that contains the $E$. coli lac $Z$ gene, which codes for the $\beta$-galactosidase ( $\beta$-gal) protein, and the viral packaging sequence [33]. All cell lines were cultured at 37 ${ }^{\circ} \mathrm{C}$ in $9 \% \mathrm{CO}_{2}$.

\section{Virus Production System}

H1-BAG cells have integrated an unknown number of copies of the pBAG plasmid containing the viral packaging or psi sequence from the Gag polyprotein and the lac $Z$ gene under the control of the viral 5' LTR. All other plasmids used to create viral particles contain DNA for the structural and enzymatic components required for particle production under the commonly used cytomegalovirus (CMV) promoter and do not 
A.

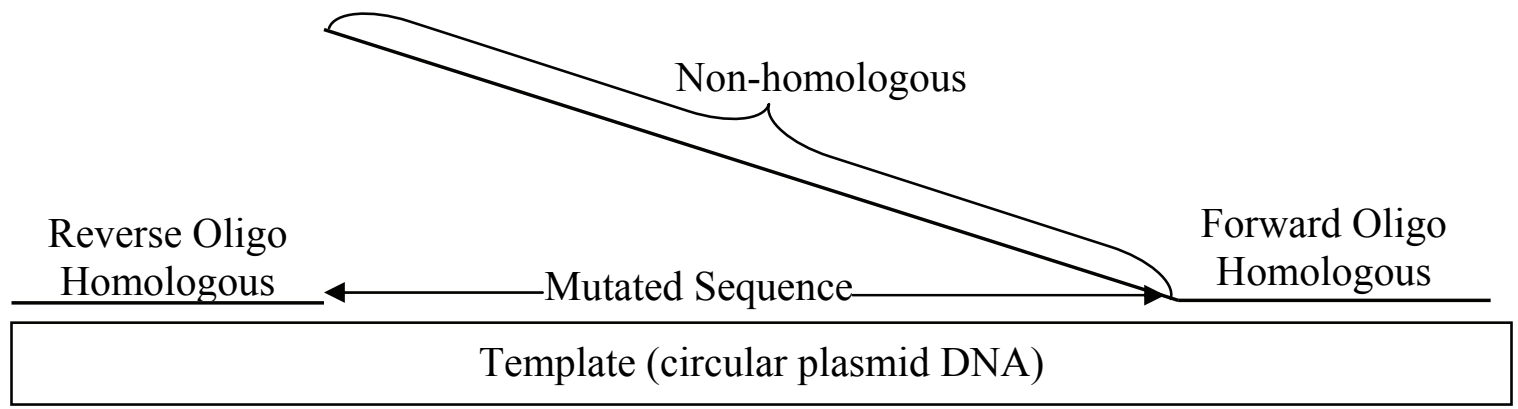

B.

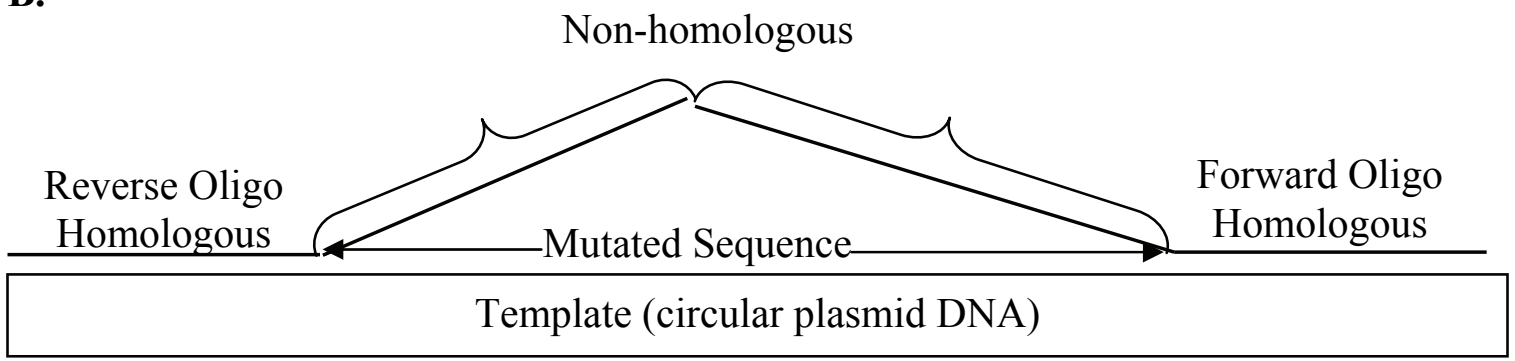

Figure 2-1. Schematic Representation of ExSite Mutagenesis Oligonucleotides. ExSite oligonucleotides were designed using either of two methods: Mutated sequence located on (A) the forward oligonucleotide only or (B) both the forward and reverse oligonucleotides. There are no gaps in sequence between the forward and reverse oligonucleotides using either primer design method, thus the mutations are incorporated as the DNA sequence is copied by DNA polymerase and amplified during each round of PCR. The number of nucleotides altered by any primer designed using this method is extremely variable. 
contain the packaging sequence. These plasmids are therefore only transiently available for use in the producer cells and are not incorporated into virions. As a result, the virus is replication deficient. When it enters a host cell, be it through interactions with the endogenous or a targeted receptor, its genomic material consisting only of that which codes for the packaging sequence and lac $Z$ is integrated into the host cell genome. No structural or enzymatic genes are present, thus no particles can be produced as a result of host cell infection; the only genes transcribed are our reporter gene, lacZ, and any selection gene present (e.g. neomycin). Ultimately, these genes will either be replaced by or coupled with the gene of interest required for gene therapy.

Two-Plasmid System of Retroviral Virus Production. One plasmid coding for the viral genome (5' and 3' LTRs, gag, pol, and env genes) minus the packaging sequence in pcDNA3 (plasmid number 719, created by former graduate student T. Zavorotinskaya) was transiently transfected into H1-BAG cells using the calcium phosphate coprecipitation method. The 719 plasmid was later modified by T. Zavorotinskaya as she sought to improve virus production by reducing the size of the plasmid by removing the neomycin gene from the pcDNA3 portion consequently creating the 752 plasmid mentioned in Chapter 4. The second plasmid required for viral production is the provirus within the H1-BAG genome.

Three-Plasmid System of Retroviral Virus Production. In an effort to reduce the probability of a homologous recombination event between the 5' and 3' portions of the structural plasmid and the viral DNA present in the H1-BAG cell genome that might result in generation of replication competent recombinant virus, 752 was split into two portions by T. Zavorotinskaya; the first, 3240, contained gag, pol, and a truncated env within pcDNA3_del Neo. The second, 3245, contained the env gene and the necessary splice donor and splice acceptor sequences from gag and pol respectively. The 3245 plasmid was further modified by T. Sullivan who improved the splice donor and splice acceptor sequences which enhanced viral envelope production considerably (unpublished observation). This plasmid was termed TS45. Sequence analysis performed during the course of these thesis studies revealed that the 3240 plasmid had more of the env sequence than anticipated. This extraneous sequence was subsequently removed to create the GV-6 plasmid described in Appendix A.

The three-plasmid system required the use of pristine DNA. Any contaminants present in the preparation of these plasmids resulted in reduced particle production. This phenomenon became more pronounced when the level of purity between the transfected plasmid preparations varied. The use of the three-plasmid system was determined to be unnecessary after it was determined that no replication competent virus was detected after performing a replication competent retrovirus (RCR) marker rescue assay on five independent virus productions made using the two plasmid system (200 $\mathrm{ml}$ each). Briefly, NIH 3T3 cells were infected with a minimum of $1 / 100^{\text {th }}$ of virus stock volume and passaged for three weeks to amplify the amount of virus present. The harvested supernatant was then applied (after filtration and the addition of polybrene, see below) to 
naïve NIH 3T3-BAG (NIH 3T3 cells containing pBAG in their genome) cells overnight in an effort to encourage incorporation of the pBAG genome into viral particles being produced. These freshly infected cells were fed and allowed to produce virus for 48 hours. Supernatant from these cells was then applied (again after filtration and the addition of ploybrene) to naïve NIH 3 T3 cells which were fixed and stained with X-gal after 48 hours. Any cells expressing $\beta$-gal activity would indicate transduction of the rescued viral genome by RCR.

\section{Virus Harvest}

The 24 and 48 hour viral supernatants were filtered through a $0.45 \mu \mathrm{m}$ filter to remove any contaminating cells. The filtered supernatant was then either pelleted $\left(4^{\circ} \mathrm{C}\right.$, $30,000 \mathrm{rpm}, 1 \mathrm{hr} .30$ min., Beckman SW-40 rotor), resuspended in $1 \mathrm{x}$ PBS at 1/225 ${ }^{\text {th }}$ its

original volume, and stored at $-80{ }^{\circ} \mathrm{C}$ prior to Western blot analysis or titer determination.

\section{Cell Lysate}

Immediately after the 48 hour viral supernatent was harvested from the transfected H1-BAG cells, approximately $1 \times 10^{6}$ cells were incubated with NP-40 lysis buffer (1\% NP-40, $50 \mathrm{mM}$ Tris [pH 8.8], $150 \mathrm{mM} \mathrm{NaCl})$ containing protease inhibitor cocktail $(1: 25$; Sigma P-8340) for 20 minutes at $4{ }^{\circ} \mathrm{C}$ and pelleted to remove nuclei and cell debris $\left(4{ }^{\circ} \mathrm{C}\right.$, $14,000 \mathrm{rpm}, 10 \mathrm{~min}$., Eppendorf $5415 \mathrm{C}$ centrifuge). Lysates were treated with $10 \% \mathrm{SDS}$ $(0.1 \%$ [final] $)$ and stored at $-80{ }^{\circ} \mathrm{C}$ prior to SDS-PAGE separation.

\section{Infection and Titration}

Several 24-well plates were seeded at approximately $1.5 \times 10^{5}$ cells per well if using NIH 3 T3 cells or $2.3 \times 10^{5}$ cells per well if using 293 or 293 progeny cells and were exposed in quadruplicate to 10 -fold serial dilutions of viral supernatant containing 8 $\mu \mathrm{g} / \mu \mathrm{l}$ Polybrene (1,5-Dimethyl-1,5-diazaundecamethylene polymethobromide, Sigma). Cells were fixed 48 hours post exposure with $0.5 \%$ Gluteraldehyde (Sigma) and stained with X-gal (5-bromo-4-chloro-3-indolyl $\beta$-D-galactopyranoside, Invitrogen). This process allowed for the identification of infected cells able to use their acquired $\beta$-gal activity to break this substrate down into its constituent components, galactose and 5bromo-4-chloro-3-hydroxyindole the latter of which is oxidized to become an insoluble blue molecule known as 5,5'-dibromo-4,4'-dichloro-indigo. Titers were determined by endpoint dilution unless otherwise noted.

\section{SDS-PAGE and Western Blot Analysis}

Viral pellet resuspensions $(10 \mu \mathrm{l})$ were diluted 1:1 in $2 \times$ SDS loading buffer, denatured by boiling for 5 minutes, and run on either an $8 \%$ or $10-20 \%$ gradient SDS- 
PAGE gel (BioRad). 8\% SDS-PAGE gels were cast from a 30\% Acrylamide-Bis Solution, 29:1 (Bio-Rad) during the SDF-1 $\alpha /$ RBS studies and pre-cast (BioRad) during the HBS studies. The separated proteins were then transferred to nitrocellulose (Protran, Schleicher \& Schuell) and incubated with goat anti-Rauscher-gp70 (1:100, Quality Biotech, Inc.) or goat anti-Rauscher-p30 (1:10,000, Quality Biotech, Inc.) antibody for one hour followed by horseradish peroxidase (HRP) conjugated mouse anti-goat (1:5000; Sigma) antibody for one hour.

Cell lysates $(10 \mu \mathrm{l})$ were diluted 1:1 in 2 x SDS loading buffer, boiled for 5 minutes, and separated on an $8 \%$ SDS-PAGE gel. The proteins were then transferred to nitrocellulose and incubated with goat anti-Rauscher-gp70 followed by mouse antigoat/HRP (1:5000, Sigma) as described previously or rabbit anti-actin (1:500, Sigma) antibody for one hour followed by goat anti-rabbit/HRP (1:5000, Sigma) antibody for one hour. Blots were developed using a chemiluminescent substrate (SuperSignal, Pierce). 


\section{Chapter 3. Investigation of the Impact Replacing the Putative MoMLV Receptor Binding Site with a Large Ligand Has on Envelope Expression and Infection}

\section{Introduction}

With the success of the Sst/RBS chimeric envelope still fresh in our minds, we set out to explore some logical boundaries of the design. What other ligands might be candidates for replacement of this putative MoMLV receptor binding site (RBS)? What constraints might exist? Would we be limited to ligands of a certain size and/or structure? How large a ligand could we use and how much secondary structure might be too much?

Previous studies had shown that insertion of a fifteen amino acid integrin-binding peptide or a single chain antibody fragment between serine $78\left(\mathrm{~S}_{78}\right)$ and proline $79\left(\mathrm{P}_{79}\right)$ (numbering relative to the amino- or N-terminus) of the MoMLV mature envelope protein resulted in exposure of the inserted sequences at the surface of the envelope protein and did not interfere with assembly of the chimeric proteins onto virions [20, 21]. Subsequently, the insertion amino acids lysine $22\left(\mathrm{~K}_{22}\right)$ through lysine $89\left(\mathrm{~K}_{89}\right)$ of the cystine-any amino acid-cystine (CXC) ligand CXCL-12, also known as stromal derived factor 1-alpha (SDF-1 $\alpha$ ), into the MoMLV envelope protein at $\mathrm{P}_{79}$ resulted in the production of a virus able to transduce cells expressing the CXCR-4 receptor [54]. Based on this information, we designed five chimeric envelope proteins with SDF- $1 \alpha$ replacing the RBS each with varying degrees of flexible flanking sequence and differences in the number of residues replaced within the envelope protein.

SDF-1 $\alpha$ is a CXC chemokine originally associated with bone marrow cell movement that has been shown to bind its receptor as a monomer [55-58]. SDF-1 $\alpha$ and its Gcoupled protein receptor, CXCR-4 (formerly known as HUMSTER [59], LESTR [60], and fusin [61]), have been linked to highly metastatic cancers as well as the migration of cancer cells to specific tissues or organs, particularly movement of breast cancer cells to the lung and lymph nodes [62-64]. Primary breast tumor cells have been shown to express significantly higher levels of CXCR-4 than normal breast epithelial cells [64, 65]. It is our belief that vectors targeted to breast cancer cells expressing this receptor would be an effective tool against primary tumors as well as metastatic cells that have moved to other locations in the body such as the brain, bone marrow, and lymphatic system.

\section{Materials and Methods}

Construction of Plasmids for SDF-1a/RBS Chimeras. Due to the larger size of the SDF-1 $\alpha$ gene with respect to the limits imposed by oligonucleotide synthesis, the SDF$1 \alpha /$ RBS plasmids were made in three steps. All oligonucleotides used to construct and amplify these plasmids are listed in Table 3-1. Table 3-2 lists the PCR parameters used to create each vector and amplify the SDF-1 $\alpha$ insert. 
Table 3-1. Table of Oligos Used to Produce and Identify SDF-1a/RBS and Related Constructs.

\begin{tabular}{|c|c|}
\hline Name & Sequence \\
\hline Fwd A & $\begin{array}{l}5 \text { ' - agcggtggtggctactggggattggagtactctggtggaggaaagcctgtaagcttaagtggattcaggagtacctcgagttaacctcctc } \\
\text { acccetc }-3 \text {, }\end{array}$ \\
\hline Fwd B & 5 '- tctggtgggggaaagcctgtaagcttaagtggattcaggagtacctcgagaaggctttaaacaaggaacctttaacctccctcacc -3' \\
\hline Fwd C & 5 ' - tctggtggaaagcctgtaagcttaagtggattcaggagtacctcgagttaacctccetcaccctc-3' \\
\hline Fwd D & $\begin{array}{l}5 \text { ' - agcggtggtggctactggggattggagtactctggtggaggaaaacctgtaagcttaagtggattcaggagtacgaacctttaacctccetc } \\
\text { acc }-3 \text {, }\end{array}$ \\
\hline Fwd E & 5 '- tctggtggaaagcctgtaagcttaagtggatccaggagtacgaacctttaacctccctcacc -3 ' \\
\hline Fwd G & 5 ' - ctcgagaaggcattgaacaaatccagaggctgttccagagactgcgaagaac -3 ' \\
\hline Rev A, D & 5 '- gtgggctaacatacataaatctgggg -3 ' \\
\hline Rev B & 5 '- atattctageccccaataagatggtccatggtgggc -3 , \\
\hline Rev C, E & 5' - tagcccccaataagatggtccatggtgggctaacatacataaatctgggg -3 ' \\
\hline Rev G & 5 ' - gtactcttggatccacttaagcttacgggcttaccgcggctgctgccccetgagcaacaag -3 ' \\
\hline Fwd Ins 1 & 5 '- agcttgagctacagatgcccetgcagattcttcgaaagccatgttgccagagccaacgtcaagcatctcaaaattctcaacactc -3 , \\
\hline Fwd Ins 2 & 5' - caaactgtgcccttcagattgtagcccggctgaagaacaacaacagacaagtgtgcattgacccga -3 ' \\
\hline Rev Ins 1 & 5 ' - agcttcgggtcaatgcagacttgtctgttgttgttcttcagccggg -3 ' \\
\hline Rev Ins 2 & 5 ' - ctacaatctgaagggcacagtttggagtgttgagaattttgagatgcttgac -3 , \\
\hline Rev Ins 3 & 5 ' - gttggctctggcaacatggctttcgaagaatctgcaggggcatctgtagctca -3 ' \\
\hline SDF-1a Insert Amp Sense & 5 ' - agtctgtaagcttgagctacagatgec -3 , \\
\hline SDF-1a Insert Amp & 5 '- acacttaagcttcgggtcaatgcacac -3 ' \\
\hline CXCR4 as & 5'- ggctactggagcactcag -3' \\
\hline
\end{tabular}


Table 3-2. PCR Mutagenesis Parameters Used to Create SDF-1a Vectors and Amplify the SDF-1 $\alpha$ Insert.

\begin{tabular}{|c|c|}
\hline Product Name & Parameters \\
\hline SDF-1 $\alpha$ vector $\mathrm{A}$ & 1 cycle: $95{ }^{\circ} \mathrm{C}$ for 2 min.; 18 cycles: $95^{\circ} \mathrm{C}$ for $30 \mathrm{sec} ., 55^{\circ} \mathrm{C}$ for 1 min., $68^{\circ} \mathrm{C}$ for $10 \mathrm{~min} . ; 4{ }^{\circ} \mathrm{C}$ Hold \\
\hline SDF-1 $\alpha$ vector B & $\begin{array}{l}1 \text { cycle: } 95^{\circ} \mathrm{C} \text { for } 2 \mathrm{~min} . ; 5 \text { cycles: } 95^{\circ} \mathrm{C} \text { for } 30 \mathrm{sec} ., 50^{\circ} \mathrm{C} \text { for } 1 \mathrm{~min} ., 68^{\circ} \mathrm{C} \text { for } 10 \mathrm{~min} \text {; } \\
20 \text { cycles: } 95^{\circ} \mathrm{C} \text { for } 30 \mathrm{sec} ., 55^{\circ} \mathrm{C} \text { for } 1 \text { min., } 68^{\circ} \mathrm{C} \text { for } 10 \text { min.; } 4^{\circ} \mathrm{C} \text { Hold }\end{array}$ \\
\hline SDF-1 $\alpha$ vector $\mathrm{C}$ & $\begin{array}{l}1 \text { cycle: } 95^{\circ} \mathrm{C} \text { for } 2 \text { min.; } 5 \text { cycles: } 95^{\circ} \mathrm{C} \text { for } 30 \mathrm{sec} ., 50^{\circ} \mathrm{C} \text { for } 1 \text { min., } 68^{\circ} \mathrm{C} \text { for } 10 \mathrm{~min} \text {; } \\
20 \text { cycles: } 95^{\circ} \mathrm{C} \text { for } 30 \mathrm{sec} ., 55^{\circ} \mathrm{C} \text { for } 1 \text { min., } 68^{\circ} \mathrm{C} \text { for } 10 \text { min.; } 4^{\circ} \mathrm{C} \text { Hold }\end{array}$ \\
\hline SDF-1 $\alpha$ vector $\mathrm{D}$ & 1 cycle: $95^{\circ} \mathrm{C}$ for 2 min.; 18 cycles: $95^{\circ} \mathrm{C}$ for $30 \mathrm{sec} ., 55^{\circ} \mathrm{C}$ for 1 min., $68^{\circ} \mathrm{C}$ for $10 \mathrm{~min} . ;{ }^{\circ} \mathrm{C}$ Hold \\
\hline $\mathrm{SDF}-1 \alpha$ vector $\mathrm{E}$ & $\begin{array}{l}1 \text { cycle: } 95^{\circ} \mathrm{C} \text { for } 2 \mathrm{~min} \text {; } 5 \text { cycles: } 95^{\circ} \mathrm{C} \text { for } 30 \mathrm{sec} \text {., } 50^{\circ} \mathrm{C} \text { for } 1 \mathrm{~min} ., 68^{\circ} \mathrm{C} \text { for } 10 \mathrm{~min} \text {; } \\
20 \text { cycles: } 95^{\circ} \mathrm{C} \text { for } 30 \mathrm{sec} ., 55^{\circ} \mathrm{C} \text { for } 1 \text { min., } 68^{\circ} \mathrm{C} \text { for } 10 \text { min.; } 4^{\circ} \mathrm{C} \text { Hold }\end{array}$ \\
\hline SDF-1 $\alpha$ vector $\mathrm{G}$ & $\begin{array}{l}\text { Round } 1 \text { - } 1 \text { cycle: } 94^{\circ} \mathrm{C} \text { for } 2 \mathrm{~min} . ; 5 \text { cycles: } 94^{\circ} \mathrm{C} \text { for } 30 \mathrm{sec} ., 62^{\circ} \mathrm{C} \text { for } 1 \text { min., } 68^{\circ} \mathrm{C} \text { for } 10 \mathrm{~min} \text {; } \\
20 \text { cycles: } 94^{\circ} \mathrm{C} \text { for } 30 \mathrm{sec} \text {., } 67^{\circ} \mathrm{C} \text { for } 1 \mathrm{~min} \text {., } 68^{\circ} \mathrm{C} \text { for } 15 \mathrm{~min} \text {.; } 4^{\circ} \mathrm{C} \text { Hold } \\
\text { Round } 2-95^{\circ} \mathrm{C} \text { for } 2 \mathrm{~min} . ; 25 \text { cycles: } 95^{\circ} \mathrm{C} \text { for } 30 \mathrm{sec} .68^{\circ} \mathrm{C} \text { for } 16 \text { min.; } 4{ }^{\circ} \mathrm{C} \text { hold }\end{array}$ \\
\hline SDF-1 $\alpha$ Insert & $\begin{array}{l}1 \text { cycle: } 96{ }^{\circ} \mathrm{C} \text { for } 4 \text { min.; } 5 \text { cycles: } 96^{\circ} \mathrm{C} \text { for } 1 \text { min., } 52^{\circ} \mathrm{C} \text { for } 1 \text { min., } 72^{\circ} \mathrm{C} \text { for } 20 \text { min.; } \\
25 \text { cycles: } 96{ }^{\circ} \mathrm{C} \text { for } 1 \text { min., } 60{ }^{\circ} \mathrm{C} \text { for } 1 \text { min., } 72^{\circ} \mathrm{C} \text { for } 10 \text { min.; } 4{ }^{\circ} \mathrm{C} \text { hold }\end{array}$ \\
\hline
\end{tabular}


First, vectors were created using the slightly modified ExSite mutagenesis protocol described in Chapter 2 and the oligonucleotides listed in Table 3-1. For plasmids SDF$1 \alpha /$ RBS vector A through E, oligonucleotides were designed to introduce mutations using the forward primer. The SDF- $\alpha /$ RBS vector G oligonucleotides were designed to introduce mutations using both the forward and reverse primers. Primers were applied to a 3245 plasmid DNA template (described in Chapter 2), and PCR mutagenesis products were purified from randomly picked $E$. coli strain Top-10F' colonies, analyzed by restriction enzyme digestion for the acquisition of a HindIII site introduced into all the vectors during mutagenesis, and verified by DNA sequence analysis.

Second, amino acids 25 through 75 of SDF-1 $\alpha$ (GenBank accession number BC039893) [66] were recapitulated by annealing and ligating the two forward and three reverse oligonucleotides Fwd Ins 1 and 2 and Rev Ins 1, 2, and 3 listed in Table 3-1. This DNA fragment was PCR amplified using the SDF-1 $\alpha$ Insert Amp Sense and Antisense oligonucleotides, the product was digested with HindIII, and the resulting, approximately 200 base pair (bp) fragment, was ligated into the pUC18 HindIII site. The correct sequence was verified by DNA sequence analysis.

Finally, plasmids SDF-1 $\alpha /$ RBS vector A through E and the pUC18-based plasmid carrying the SDF-1 $\alpha$ insert were digested with HindIII. The SDF-1 $\alpha$ insert was then ligated to the vector plasmids to form the SDF-1 $\alpha /$ RBS constructs. All constructs were verified by DNA sequence analysis and the final protein sequences of SDF-1 $\alpha$ and SDF$1 \alpha /$ RBS constructs A through $\mathrm{G}$ are listed in Table 3-3.

Cell Lines and Receptor Plasmid Construction. The NIH 3T3 and 293 cell lines were maintained as described in Chapter 2. The pcCXCR4 plasmid was constructed by subcloning the approximately $2000 \mathrm{bp}$ CXCR-4 cDNA EcoRI fragment from pBABECXCR4-puro (gift from N. Landau) [67] into the EcoRI site of pcDNA3 (Invitrogen) under the control of the CMV promoter. Correct sequence was verified by DNA sequence analysis. Human 293 cells were transiently transfected with the pcCXCR4 plasmid using FuGene 6 (Roche) lipid transfection reagent at a 6:1 ratio of FuGene $6(\mu \mathrm{l})$ to plasmid DNA $(\mu \mathrm{g})$ and seeded on 24-well plates as described in Chapter 2 at 24 hours post transfection. These cells were referred to as 293/CXCR4 cells.

Flow Cytometry. Approximately 1 x $10^{6}$ cells were incubated with phycoerythrin (PE) conjugated mouse anti-human CXCR-4 (1:25; BD Biosciences) diluted in $1 \mathrm{x}$ PBA for 1 hour at room temperature. Calcein AM $(0.1 \mu \mathrm{M}$ [final]; Invitrogen), a live/dead stain with similar absorbance and emission wavelengths to FITC, was added during the final 5 minutes of incubation. 1 x $10^{5}$ live (Calcein AM positive) cells were analyzed using a BD FACScalibur Flow Cytometer.

Virus Production, Infection, and Titration. Virus production was as per the three plasmid system described in Chapter 2, using $25 \mu \mathrm{g}$ of the gag-pol encoding plasmid, 
Table 3-3. Alignment of SDF-1 $\alpha$ and SDF-1 $\alpha /$ RBS Protein Sequences.

\begin{tabular}{|c|c|c|c|}
\hline \multirow[b]{2}{*}{ Name } & \multicolumn{3}{|c|}{ Sequence } \\
\hline & MoMLV + flexible linkers & SDF-1 $\alpha$ & MoMLV \\
\hline SDF-1 $1 \alpha /$ RBS A & $\ldots \mathrm{H}_{50} \mathbf{S}^{1} \mathbf{G G G Y}{ }_{55} \mathrm{~W} \mathrm{GLEY}_{60} \mathbf{S G G G}$ & $\mathrm{K}_{22} \mathrm{P} V^{2} \ldots{ }^{3} L_{76} \mathrm{KWIQEYLE} 84$ & $\mathrm{~L}_{89}$ TSLTPR.. \\
\hline SDF-1 $1 \alpha /$ RBS B & $\ldots \mathrm{H}_{50} \mathrm{HGPSY}_{55} \mathrm{~W} \mathrm{GLEY}_{60} \mathbf{S G G G}$ & $\mathrm{K}_{22} \mathrm{P} V \ldots L_{76} \mathrm{KWIQEYLEKALNK}{ }_{89}$ & $\mathrm{E}_{87} \mathrm{PLTSLTPR} \ldots$ \\
\hline SDF-1 $1 \alpha /$ RBS C & $\ldots \mathrm{H}_{50} \mathrm{HGPS}_{5}{ }_{5} \mathrm{WGL}_{58} \mathbf{S G G}$ & $\mathrm{K}_{22} \mathrm{P} V \ldots L_{76} \mathrm{KWIQEYLE} 84$ & $\mathrm{~L}_{89} \mathrm{~T} \mathrm{SLTPR} \ldots$ \\
\hline SDF-1 $1 \alpha /$ RBS D & $\ldots \mathrm{H}_{50} \mathbf{S G G G} \mathrm{Y}_{5}{ }_{5} \mathrm{~W} \mathrm{GLE}{ }_{60}$ SGGG & $\mathrm{K}_{22} \mathrm{P} V \ldots L_{76} \mathrm{KWIQEY}{ }_{82}$ & $\mathrm{E}_{87} \mathrm{PLTSLTPR} .$. \\
\hline SDF-1 $1 \alpha /$ RBS E & $\ldots \mathrm{H}_{50} \mathrm{HGPSY}_{55} \mathrm{WGL}_{58} \mathbf{S G G}$ & $\mathrm{K}_{22} \mathrm{P} V \ldots L_{76} \mathrm{KWIQEY}{ }_{82}$ & $\mathrm{E}_{87} \mathrm{PLTSLTPR} \ldots$ \\
\hline SDF-1 $1 \alpha /$ RBS G & $\mathbf{P}_{71} \mathrm{CCSGGSS}_{78} \mathbf{R G}$ & $\mathrm{K}_{22} \mathrm{P} V \ldots L_{76} \mathrm{KWIQEYLEKALNK}{ }_{89}$ & 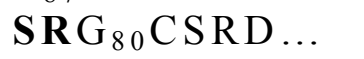 \\
\hline SDF-1 $\alpha$ Insert & $S_{25}$ LSYRCPCRFFESHVAR & NVKHLKILNTPNCALQIVARLKNNNRQ & $\mathrm{CIDP}_{75}$ \\
\hline
\end{tabular}

${ }^{1}$ Amino acids added to MoMLV protein sequence are in bold face type. ${ }^{2}$ Italicized letters signify amino acids participating in HindIII digestion. ${ }^{3}$ Residues $25-75$ of SDF-1alpha are represented by a short dotted line. Their amino acid sequence appears in the SDF-1 $\alpha$ Insert entry. 
3240, and either $40 \mu \mathrm{g}$ of each SDF-1a/RBS envelope plasmid as in the final production or $20 \mu \mathrm{g}$ as in all preceding productions. Wild type (WT) MoMLV was produced using $25 \mu \mathrm{g}$ of plasmid 3240 and $20 \mu \mathrm{g}$ of the wild type envelope protein encoding plasmid, 3245 , throughout all experiments. In experiments where different media are used during virus production, transfections were performed in DMEM supplemented with 8\% FBS.

Twenty-four hours post-transfection, producer cells were fed with the appropriate media variation and virus was harvested 24 hours later. After each harvest, cells were fed with the next appropriate media variation and virus was harvested after 24 hours.

SDS-PAGE and Western Blot Analysis. Viral pellets and producer cell lysates were collected as described in Chapter 2. Proteins were separated on an 8\% SDS-PAGE gel, transferred to nitrocellulose, detected, and developed as described in Chapter 2.

\section{Results}

Design of SDF-1a Constructs. Due to the difference in size between the fourteen amino acid Sst and that of SDF-1 $\alpha$, a slightly modified design concept based on the Sst/RBS chimera was applied. Using structural representations of FrMLV and SDF-1 $\alpha$ (PDB accession number 1VMC) [68] we used the Swiss-Model [69] and RasMol [70, 71] protein modeling programs in an attempt to position SDF-1 $\alpha$ in such a way as to replace the endogenous receptor binding site and have the least amount of impact on the natural structure of MoMLV envelope, thus maintaining proper folding and function of the envelope protein.

This modeling indicated that the least obtrusive way to incorporate SDF-1 $\alpha$ in place of the putative RBS would be to replace the segment of SU beginning at amino acids at leucine $58\left(\mathrm{~L}_{58}\right)$ or tyrosine $60\left(\mathrm{Y}_{60}\right)$ and ending at leucine $89\left(\mathrm{~L}_{89}\right)$ or glutamic acid 87 $\left(\mathrm{E}_{87}\right)$. Previous studies had shown that the C-terminal end of SDF- $1 \alpha$ has little to no bearing on its ability to bind to or activate the CXCR-4 receptor $[68,72]$, therefore we were comfortable experimenting with varying lengths of SDF- $1 \alpha$ in the hope that slightly reducing its size might be more conducive to proper folding.

We also wanted to determine if the addition of flexible linkers preceding SDF-1 $\alpha$ would help preserve its natural structure and activity within the context of the MoMLV envelope as well as that of the envelope itself. Serine-glycine linkers were introduced in two different locations, the first location being directly upstream of the MoMLV/SDF-1 $\alpha$ junction and the second slightly more upstream at histidine $50\left(\mathrm{H}_{50}\right)$. Two different forms of the linker, each potentially offering slightly different levels of flexibility, were also introduced at the origin of the junction between these two proteins.

As a positive control, the SDF- $1 \alpha /$ RBS-G chimera containing an insertion of the SDF- $1 \alpha$ amino acids 22 through 89 at MoMLV residue 79 was generated as previously described [54]. This construct was reported to have maintained the ability to infect cells 
expressing the ecotropic MLV receptor as effectively as the wild type MoMLV and to have gained the ability to infect cells expressing the CXCR-4 receptor [54].

The Chimeric SDF-1a/RBS Proteins Were Not Expressed Well on Viral Particles. Initial attempts to produce virions expressing the SDF-1 $\alpha /$ RBS envelope resulted in very low envelope expression. To combat potential folding issues we took two different approaches. First, in the event that SDF-1 $\alpha$ folding might require a less acidic environment, we produced virus in BES-buffered DMEM (pH 7.2). Secondly, to correct misfolding due to the misplacement of cystine bonds, we added a low level $(1 \mu \mathrm{g} / \mathrm{L})$ of $\beta$ mercaptoethanol (2-mercaptoethanol, Sigma; $\beta$-Me) to the producer cell media duringvirus production. Neither method produced chimeras with levels of SU comparable to MoMLV. In fact, $\beta$-Me demonstrated the ability to reduce more than just disulfide bonds by diminishing MoMLV envelope expression as well (Figure 3-1). There was no producer cell death associated with either method.

\section{SDF-1a/RBS Virus Did Not Effectively Transduce 293 Cells Transiently Expressing} $\boldsymbol{C X C R}$-4. Neither virions produced in untreated DMEM nor those produced in BESbuffered DMEM demonstrated the ability to infect cells expressing CXCR-4 (Figure 3-2). Western blot analysis of the virions (Figure 3-3) revealed an enhanced accumulation of the precursor envelope protein (gp75) which consisted of uncleaved SU and TM. This phenomenon has been seen in both infectious and noninfectious virus in the past and has no bearing on whether or not virions are able to transduce their genetic material [33]. An accumulation of precursor in this case correlated with a slightly increased ability to transduce NIH 3T3 cells which is an undesirable trait in a vector designed for mouse studies.

In an effort to increase expression of mature chimeric SU, we doubled the mass of envelope plasmid used in transfecting the H1-BAG producer cells. These chimeric viruses also showed a negligibly low level of transduction on 293/CXCR4 cells while continuing to demonstrate the ability to transduce NIH 3T3 cells (Figure 3-4) even though the level of chimeric SU on these virions was slightly increased (Figure 3-5). Analysis of the cell lysates (Figure 3-5) indicated that there may be a cleavage defect as evidenced by the lack of cleaved SU present in A, B, D, and E. The C and G envelopes appeared more amenable to cleavage by the host cell furin-like protease.

\section{Discussion}

Together these results suggest that the sheer size of SDF-1 $\alpha$ restricts its usefulness in this particular design. However, we believe there are other factors beyond size involved that may bear further experimentation. Our constructs incorporated residues $\mathrm{K}_{22}$ through $\mathrm{K}_{89}$. The SDF-1 $\alpha$ binding site has been determined to encompass $\mathrm{N}$-terminal residues 1 through 9 [72] while activation of the CXCR-4 receptor required amino acids 1-17 [68]. An SDF-1 $\alpha /$ RBS chimera in which this smaller fragment of the ligand is substituted for 

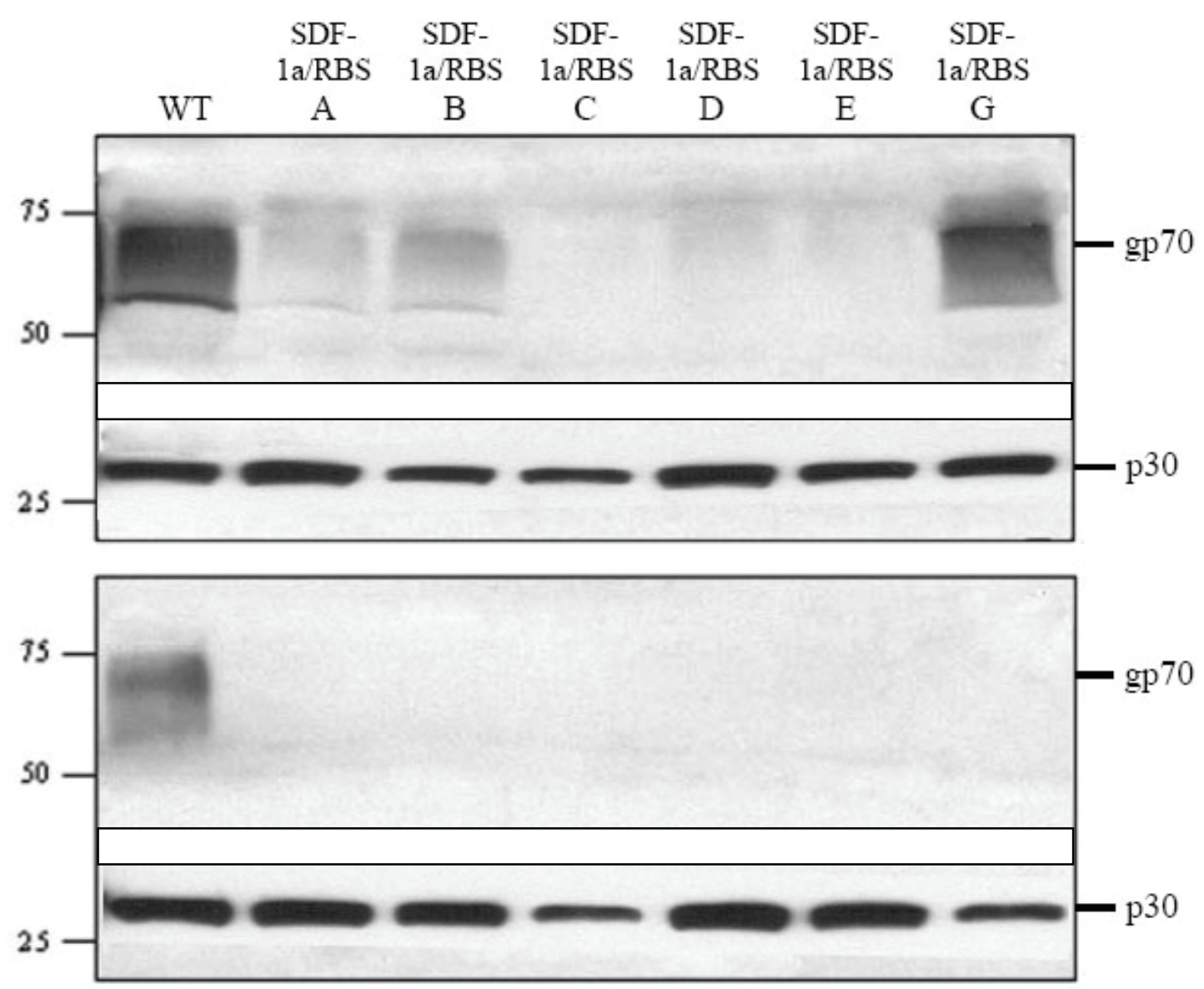

Figure 3-1. Western Blot Analysis of Viral Pellets Produced in BES-buffered DMEM and $\beta$-Me DMEM. SDF- $1 \alpha /$ RBS viruses $A$ through $G$ and wild type (WT) MoMLV were produced in BES-buffered media (top) or media containing $\beta$ mercaptoethanol [1 $\mu \mathrm{g} / \mathrm{L}]$ (bottom). The viral supernatant was pelleted and analyzed by SDS-PAGE and Western blot using antibody to the surface (gp70) protein of MoMLV envelope. Antibody to MoMLV capsid (p30) was used as a loading control. 
A.

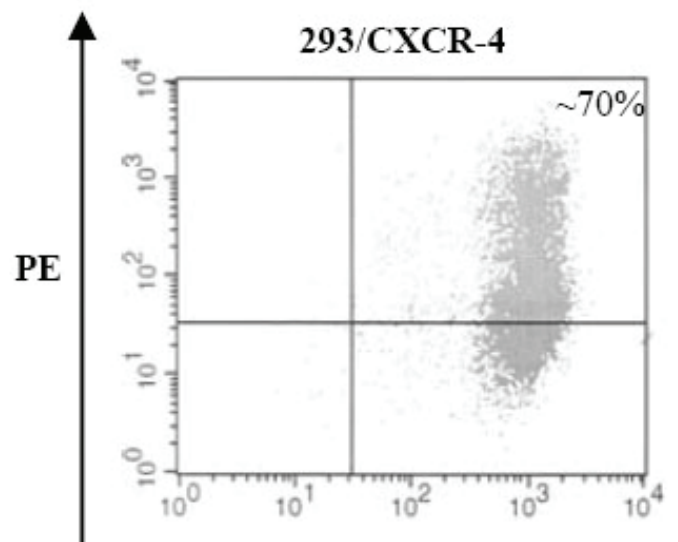

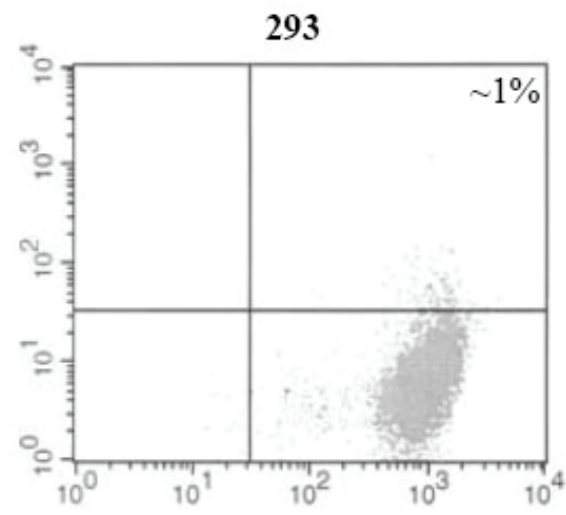

FITC

B.

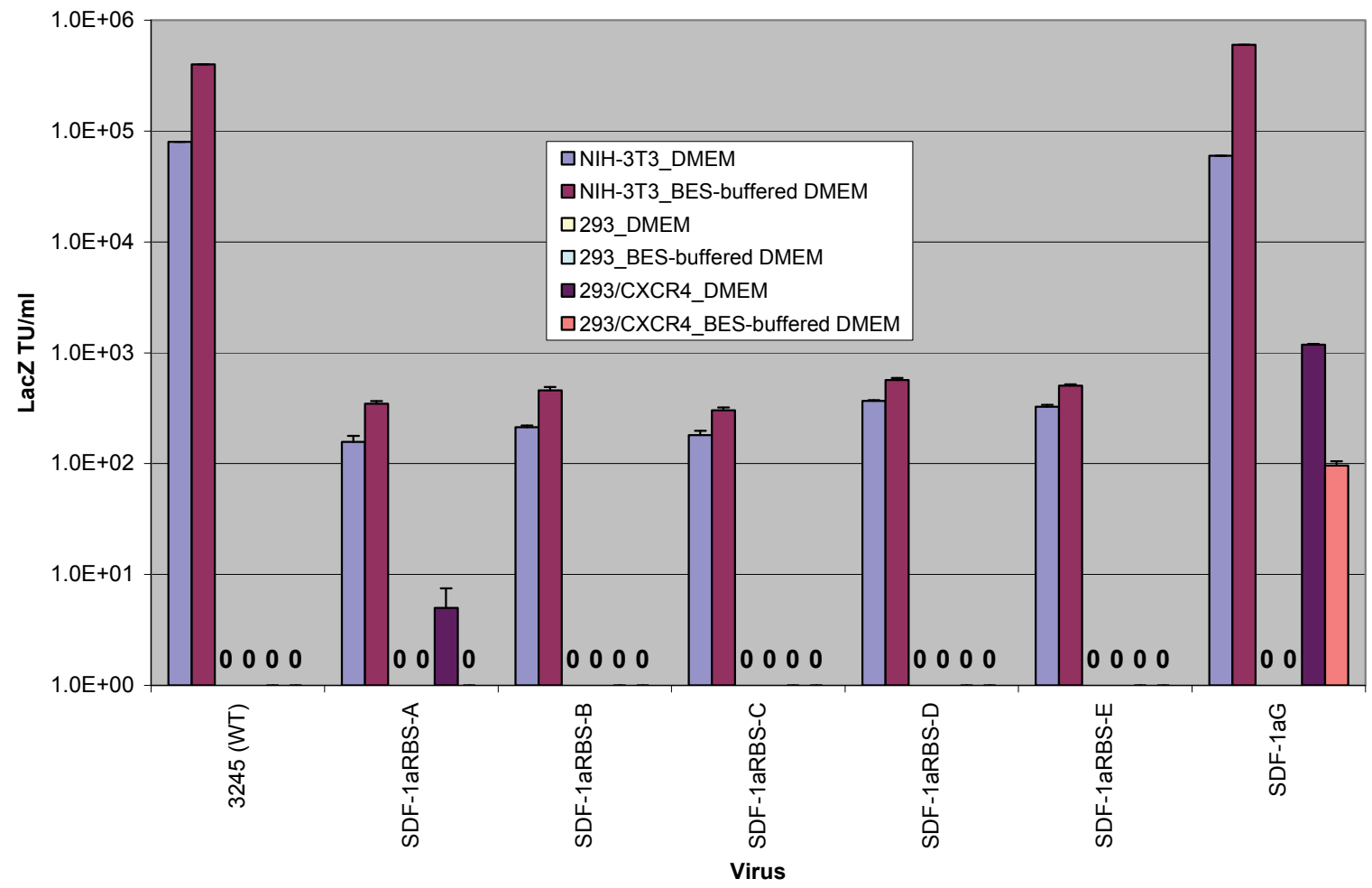

Figure 3-2. SDF-1 $\alpha /$ RBS Infection in Unaltered DMEM and BES-buffered DMEM. (A) The level of CXCR-4 expressed on the surface of the 293 cells was quantified using flow cytometry the same day as the cells were exposed to the viral supernatants. (B) NIH $3 \mathrm{~T} 3$ cells, 293 cells, and 293 cells transiently expressing the CXCR-4 receptor were exposed to viral supernatants and the resulting infection was quantitated by end-point dilution (WT MoMLV and SDF-1 $\alpha /$ RBS G) or by counting individual cells (SDF$1 \alpha /$ RBS B through E) transduced with the lac $Z$ gene. 


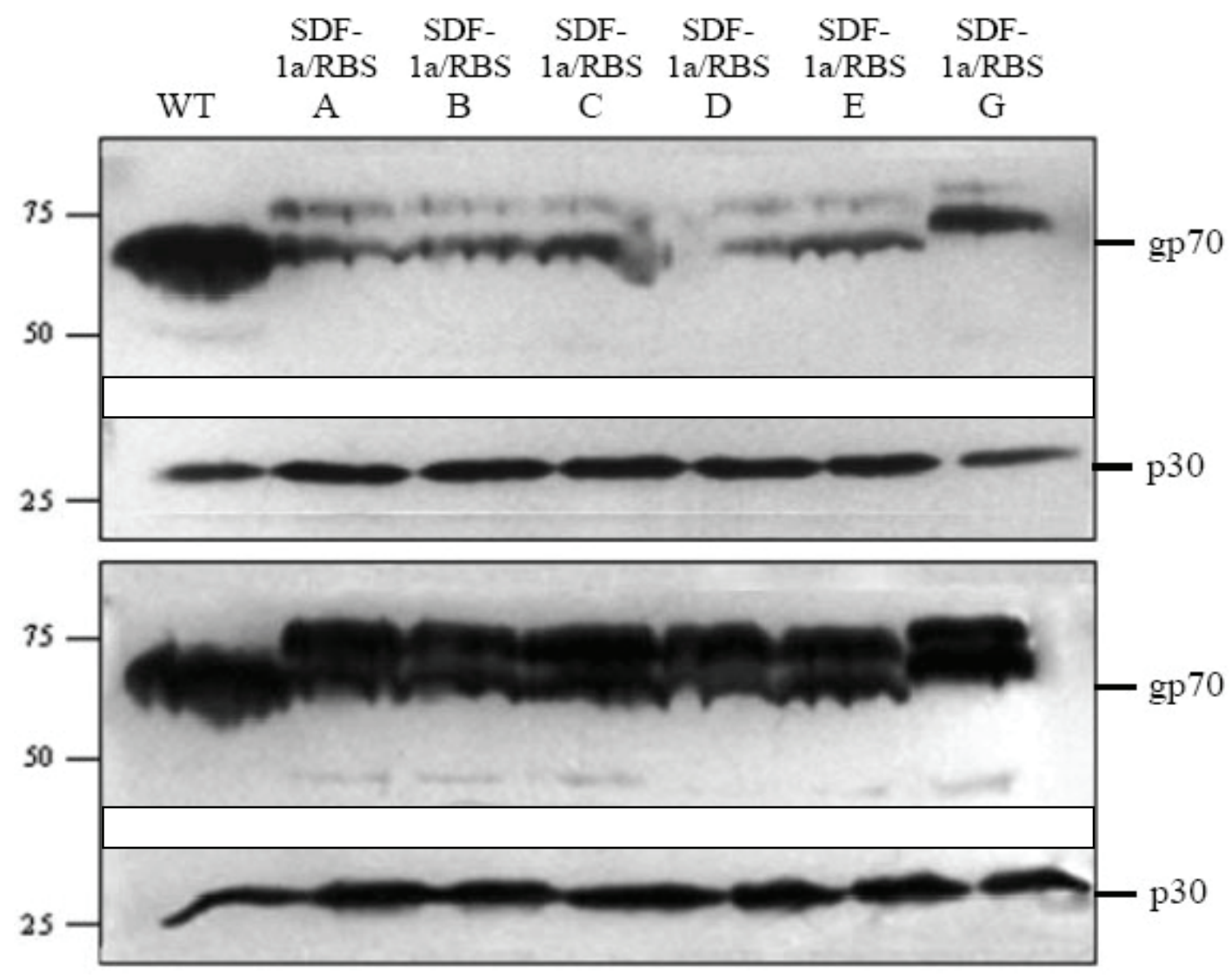

Figure 3-3. Western Blot Analysis of Viral Pellets Produced in DMEM and BESbuffered DMEM. SDF- $1 \alpha /$ RBS viruses A through $\mathrm{G}$ and WT MoMLV were produced in unaltered DMEM (top) or BES-buffered DMEM (bottom). The viral supernatant was pelleted and analyzed by SDS-PAGE and Western blot using antibody to the surface (gp70) protein of MoMLV envelope. Antibody to MoMLV capsid (p30) was used as a loading control. 
A.
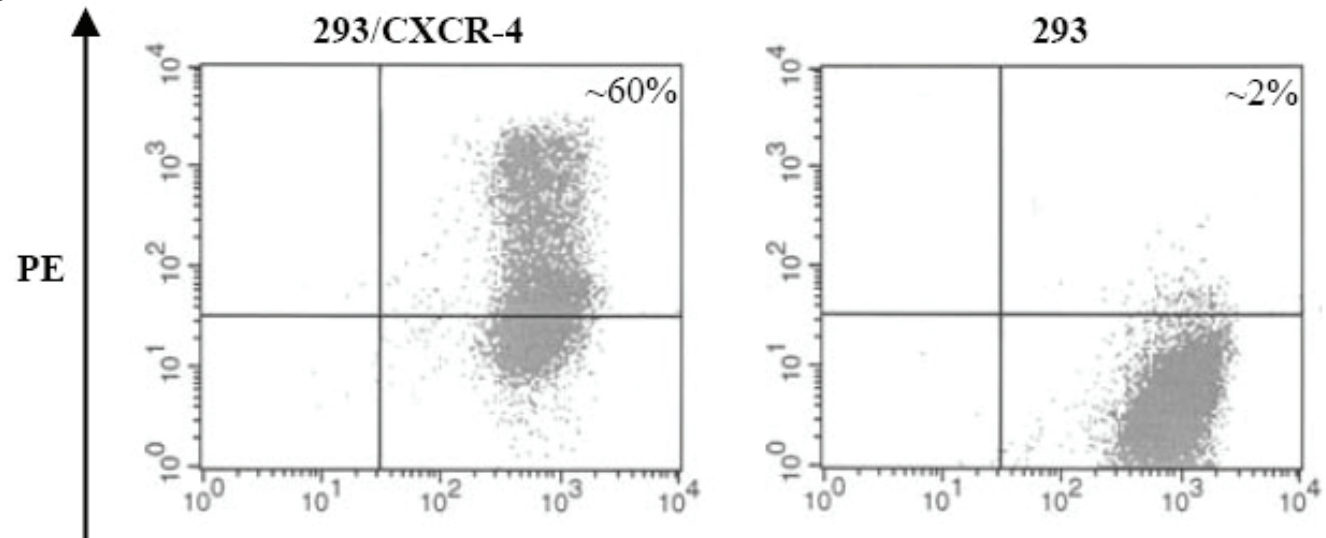

FITC

B.

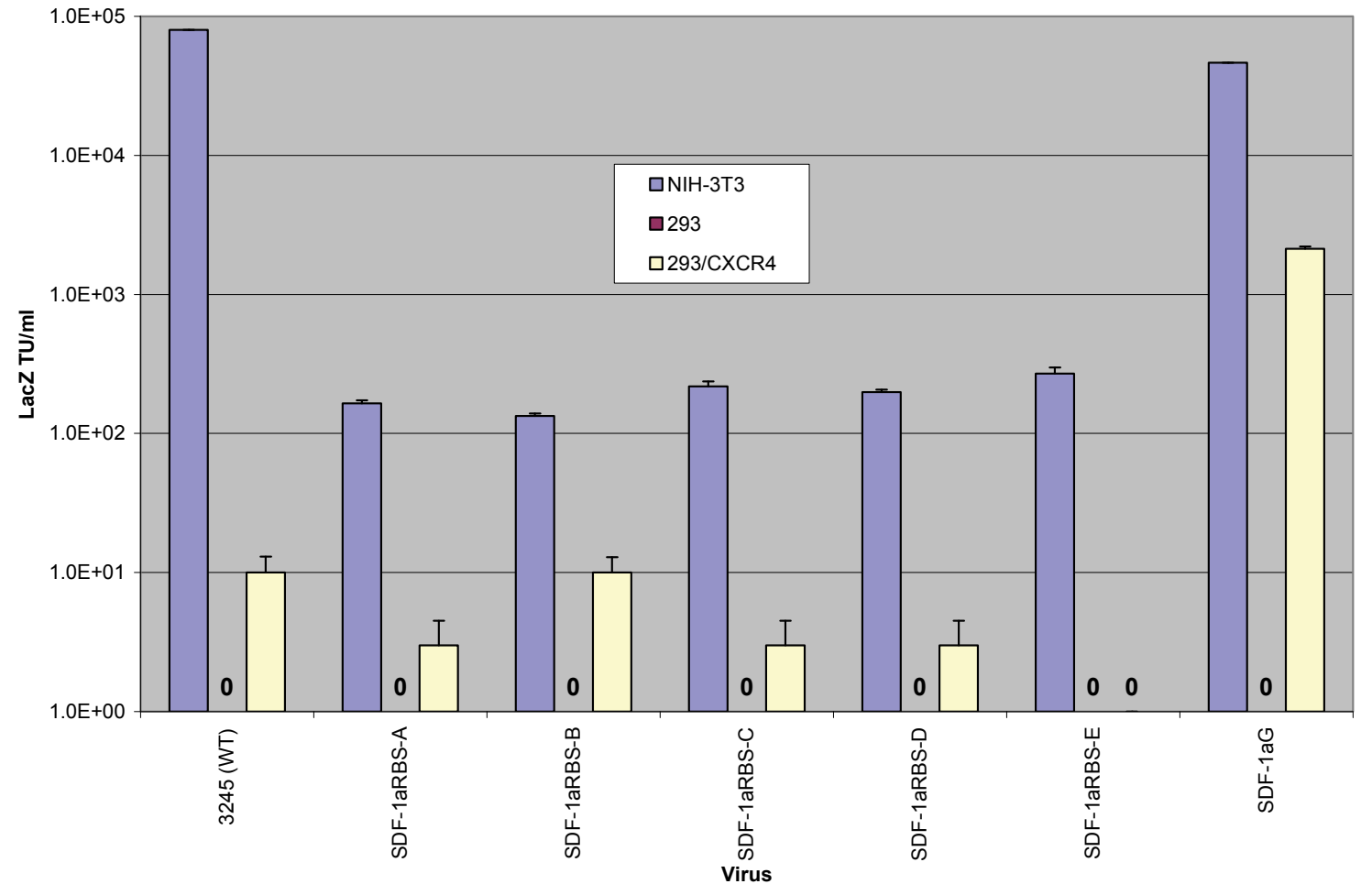

Figure 3-4. Double Envelope SDF-1a/RBS Infection in DMEM. (A) The level of CXCR-4 expressed on the surface of the 293 cells was quantified by flow cytometry the same day as the cells were exposed to the viral supernatants. (B) NIH 3 T3 cells, 293 cells, and 293 cells transiently expressing the CXCR-4 receptor were exposed to viral supernatant and the resulting infection was quantitated by end-point dilution (WT MoMLV and SDF-1 $\alpha /$ RBS G) or by counting individual cells (SDF- $1 \alpha /$ RBS B through E) transduced with the $l a c Z$ gene. 


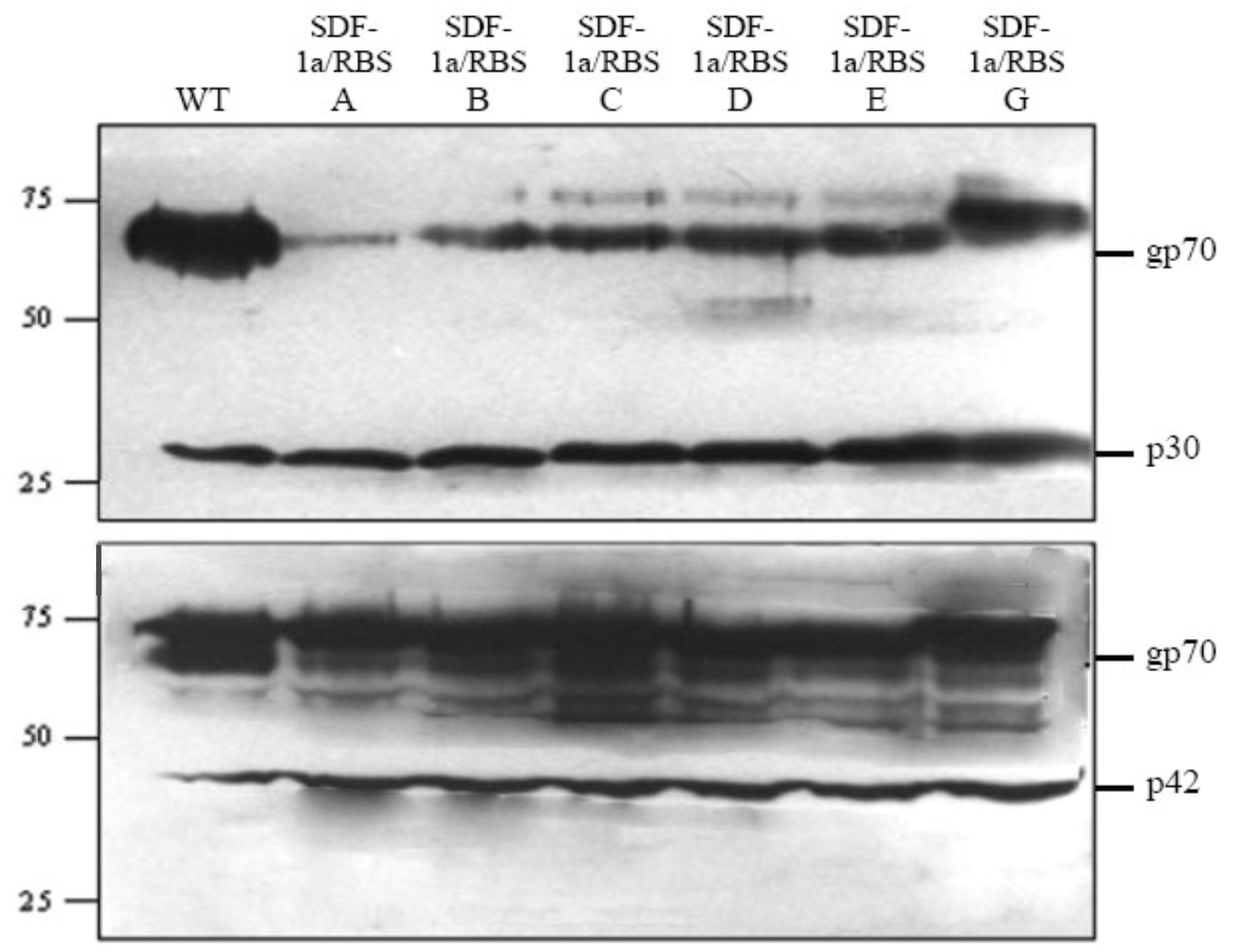

Figure 3-5. Effect of Doubling the SDF-1a/RBD Plasmid Mass during Virus

Production. 48 hour viral supernatant (top) was pelleted and analyzed by SDS-PAGE and Western blot using antibody to the surface (gp70) protein of MoMLV envelope. An antibody to MoMLV capsid (p30) was used as a loading control. Producer cell lysates (bottom) were harvested once virus production was complete and analyzed by SDSPAGE and Western blot using antibody to the surface (gp70) protein of MoMLV envelope. Antibody to actin (p42) was used as a loading control. 
the putative RBS may allow for better retention of the MoMLV envelope structure and promote higher levels of expression. The positive control SDF-1 $\alpha$ insertion construct, SDF-1 $\alpha /$ RBS G, gave a very low but consistent level of infection. Restrictions placed on the SDF-1 $\alpha$ conformation by the lack of flexibility inherent in its design may have forced the accessibility of a low affinity binding site within this portion of SDF-1 $\alpha$ that allowed entry via the CXCR-4 receptor.

As discussed in Appendix B, the configuration of the replacement peptide and the location of its binding site relative to the envelope protein may also be a limitation. If this is the case, these smaller SDF-1 $\alpha /$ RBS chimeras may express chimeric envelope proteins comparable to that of wild type virus while remaining unable to infect cells expressing CXCR-4. In this instance, perhaps the portion of CXCR-4 tropic HIV-1 SU protein, gp120, which is responsible for binding this receptor would be amenable to use in this design. Unfortunately, the exact sequence that binds the co-receptors including CXCR-4 remains unknown, although versions of the V3 loop within gp120 have demonstrated the ability to interfere with anti-CXCR-4 antibody binding suggesting that this loop may be involved in the interaction [73].

A lingering concern is the ability of these chimeras to infect NIH $3 \mathrm{~T} 3$ cells. The amino acids responsible for ecotropic receptor binding had been replaced by SDF-1 $\alpha$. Particles in which MoMLV residues 72-85 were deleted (del RBS) demonstrated no such ability. A very low level of infection by the Sst/RBS chimera was also observed on NIH 3T3 cells [46]. Perhaps these chimeras are able to infect via unidentified receptors on these cells able to bind the Sst and SDF-1 $\alpha$ ligands. Another possibility would be that these human ligands possess the ability to cross react with murine CXCR-4 and Sst receptors. However, NIH 3T3 cells are not known to express CXCR-4 [74] or SstR1-5 $[75,76]$. 


\section{Chapter 4. Mutational Analysis of the MoMLV Heparin Binding Site}

\section{Introduction}

Heparin and heparan sulfate are both members of the glycosaminoglycan (GAG) family differing in their pattern of sulfation which affects the ligands with which they interact. Heparan sulfate occurs naturally on mammalian cell plasma membranes as a post-translational modification of certain families of membrane proteins referred to as heparan sulfate proteoglycans (HSPG). Many proteins are known to bind HSPG through the use of common consensus heparan binding site (HBS) sequences defined as $\mathrm{XBBBXXBX}$ or XBBXBX where $\mathrm{X}$ is any amino acid and $\mathrm{B}$ is any basic amino acid (lysine, arginine, or histidine) [77, 78].

Several viruses have been shown to use varying degrees of HPSG binding as a means of initial attachment to their host cell. Examples include enveloped viruses, such as the herpesviruses (HSV, HHV, and CMV) [79-81], respiratory syncytial virus (RSV) [82], HIV-1 [83, 84], MMTV [85], and MLV (FrMLV and Amphotrophic MLV) [86, 87], as well as several nonenveloped viruses such as adenovirus type 2 and 5 (AdV-2 and -5) [88], adeno-associated virus type 2 (AAV-2) [89], and foot-and-mouth disease virus (FMDV) [90]. Although several methods were used to determine the ability of these viruses to bind heparan sulfate, the two most informative experiments remained to be exposure of the viral supernatant to soluble heparan sulfate or pretreatment of host cells with heparanase prior to infection. Additionally, the MMTV study incorporated a mutated envelope protein (del HBS) which confirmed the reduction in infection shown during the heparan sulfate precompetition assay. These studies collectively identified a wide range of viruses which rely on their capacity to bind cell surface HSPG to effectively infect their host cells.

A neuropathogenic variant of the Friend MLV (FrMLV), PVC-211, was recognized after passage of FrMLV in rats [91]. Further characterization of this virus demonstrated that the use of the ATRC-1 receptor was conserved, but the host cell preference of PVC211 had been shifted to brain capillary endothelial cells (BCEC) thus allowing the virus to penetrate the blood-brain barrier $[92,93]$. Comparison to wild type FrMLV revealed two point mutations within the RBD, glutamic acid 116 to glycine $\left(\mathrm{E}_{116} \mathrm{G}\right)$ and glutamic acid 127 to lysine $\left(\mathrm{E}_{127} \mathrm{~K}\right)$, which were shown to be responsible for this expanded tropism $[94,95]$. The $\mathrm{E}_{127} \mathrm{~K}$ mutation conferred an additional heparin binding motif overlapping the one naturally found in VRC [86]. It has been suggested that this acquisition increased the naturally low affinity of FrMLV for heparan thus enhancing attachment and allowing PVC-211 to infect ECC more efficiently than FrMLV [86]. Based on the sequence homology of MoMLV and FrMLV, we proposed that the addition of an overlapping HBS could also increase MoMLV infection. 


\section{Materials and Methods}

Construction of Heparin Binding Site Mutant Plasmids. Several different approaches were necessary to introduce all the desired mutations. Mutagenic oligonucleotides used to construct the HBS mutants and those specifically created for this project are listed in Table 4-1. Table 4-2 lists the PCR parameters used to create each construct.

Envelope Only Constructs. Since the gag-pol-env encoding plasmid 752 is too large for use as the template for in vitro mutagenesis using PCR methods, the env encoding plasmid TS45 (described in Chapter 2) was used as the template. Using the modified ExSite mutagenesis protocol described in Chapter 2, oligonucleotide primers were annealed to plasmid TS45 template DNA and individual products of the mutagenesis were recovered after introduction into $E$. coli DH5- $\alpha$. Sequence analysis of the purified plasmid DNAs indicated that the mutated sequence had not completely been introduced during this initial process. This partial transfer of the desired nucleotide changes from the mutagenic oligonucleotide primers resulted in missing nucleotides. We attempted to fill these gaps in sequence using Klenow ${ }^{\left(\mathrm{exo}^{+}\right)}$(New England Biolabs). This method was successful in obtaining only one of the desired mutants, TS45/HBS-4. Two approaches were taken to obtain the remaining mutants. First, QuikChange mutagenesis (described in Chapter 2) was used to introduce the missing nucleotides into those plasmids with one or two base pairs missing in the codon for histidine $110\left(\mathrm{H}_{110}\right)$ (numbering relative to MoMLV envelope N-terminus); TS45/HBS-1B, 2B, and 7B were obtained using this method. Next, QuikChange mutagenesis was used to mutate TS45/HBS-1B into TS45/HBS-3B. Finally, we employed the use of ExSite mutagenesis to introduce the TS45/HBS-5B, 6B, and 8 mutations to the TS45/HBS-4 plasmid.

Gag-pol-env Constructs. In light of the negative RCR assay results for virus produced using the two plasmid system and the nature of the DNA required for use of the three plasmid system (see Chapter 2), we opted to produce virus using the two plasmid system. To facilitate the use of this system, a PCR amplified portion of DNA containing each of the mutated HBS sequences was subcloned from the TS45 plasmid background using the PmlI and BspEI restriction sites into GV752 plasmid DNA (described in Appendix A).

Del RBS Gag-pol-env Constructs. The portion of the TS45 plasmid and each TS45/HBS plasmid spanning glutamic acid $86\left(\mathrm{E}_{86}\right)$ to the BspEI site was amplified. During this amplification, the bases encoding the RBS (amino acids 72 - 85) were replaced with a nine nucleotide sequence encoding the amino acid sequence YAS and containing a unique MluI restriction enzyme site. (see Table 4-1 for complete sequence of oligonucleotides). We then digested the product with $M l u I$ and BspEI and subcloned it into the GV752 plasmid. 
Table 4-1. Table of Oligonucleotides Used in the Production of HBS Mutation Constructs 1 through 8.

\begin{tabular}{|c|c|}
\hline Name & Sequence \\
\hline HBS Mut 1 Fwd & 5'- caagagtaacgaaggcttctacgtgtgtcctggtcctcatagaccgagaaagagtaagagctgcggtggaccggactccttctactgtgcctattg -3' \\
\hline HBS Mut 2 Fwd & 5' - caagagtaacgaaggcttctacgtgtgtcctggtcctcatagaccgagacgtagtaagagctgcggtggaccggactccttctactgtgcctattg -3' \\
\hline HBS Mut 3 Fwd & 5' - caagagtaacgaaggcttctacgtgtgtcctggtcctcatagaccgagacatagtaagagctgcggtggaccggactccttctactgtgcctattg -3' \\
\hline HBS Mut 4 Fwd & 5' - caagagtaacgaaggcttctacgtgtgtcctggtcctaagaagccgaagaagagtaagagctgcggtggaccggactccttctactgtgcctattg -3' \\
\hline HBS Mut 5 Fwd & 5'- caagagtaacgaaggcttctacgtgtgtcctggtcctagaagaccgagacgtagtagaagctgcggtggaccggactccttctactgtgcctattg -3 , \\
\hline HBS Mut 6 Fwd & 5' - caagagtaacgaaggcttctacgtgtgtcctggtcctcatagaccgagacatagtcgtagctgcggtggaccggactccttctactgtgcctattg -3, \\
\hline HBS Mut 7 Fwd & 5' - caagagtaacgaaggcttctacgtgtgtcctggtcctcataagccgaagcatagtaagagctgcggtggaccggactccttctactgtgcctattg -3 , \\
\hline HBS Mut Rev & 5 ' - tgagttgtctggtctagcttgag -3 , \\
\hline HBS Mut 1B Fwd & 5' - caagctagaccagacaactcacaagagtaacgaaggcttc -3 ' \\
\hline HBS Mut 1B Rev & 5' - gaagccttcgttactcttgtgagttgtctggtctagcttg -3 ' \\
\hline HBS Mut 2B Fwd & 5' - caagctagaccagacaactcacaagagtaacgaaggcttctac -3' (HPLC purified) \\
\hline HBS Mut 2B Rev & 5' - gtagaagccttcgttactcttgtgagttgtctggtctagcttg -3' \\
\hline HBS Mut 3B Fwd & 5' - ctggtcctcatagaccgagacatagtaagagctgcggtggac -3 ' \\
\hline HBS Mut 3B Rev & 5' - gtccaccgcagctcttactatgtctcggtctatgaggaccag -3 ' \\
\hline HBS Mut 5B Fwd & 5' - cgtcgtcctcgtcgttcgcgaagctgcggtggaccggactc -3 ' \\
\hline HBS Mut 6B Fwd & 5' - catcgtcctcgtcattcgcgaagctgcggtggaccggactc -3 ' \\
\hline HBS Mut 7B Fwd & 5'- ctcaagctagaccagacaactcacaagagtaacgaaggcttctac -3 , \\
\hline HBS Mut 7B Rev & 5' - gtagaagccttcgttactcttgtgagttgtctggtctagcttgag -3 ' \\
\hline HBS Mut 8 Fwd & 5'- gctgcacctgcagcaagcgctagctgcggtggaccggactc -3, \\
\hline HBS Mut B Rev & 5' - aggaccaggacacacgtagaag -3 ' \\
\hline del RBS Fwd & 5'- atataaacgcgtccgaagaacctttaacctccctcac -3 ' \\
\hline del RBS Rev & 5'- cctgatgtgttttgggaactgc -3 ' \\
\hline
\end{tabular}


Table 4-2. PCR Mutagenesis Parameters Used to Create SDF-1 $\alpha$ Vectors and Amplify the SDF-1 $\alpha$ Insert.

\begin{tabular}{|c|c|}
\hline Product Name & Parameters \\
\hline TS45/HBS-1 & $\begin{array}{l}1 \text { cycle: } 95^{\circ} \mathrm{C} \text { for } 2 \mathrm{~min} . ; 5 \text { cycles: } 95^{\circ} \mathrm{C} \text { for } 30 \mathrm{sec} ., 54{ }^{\circ} \mathrm{C} \text { for } 1 \mathrm{~min} ., 68^{\circ} \mathrm{C} \text { for } 10 \mathrm{~min} . ; \\
25 \text { cycles: } 95^{\circ} \mathrm{C} \text { for } 30 \mathrm{sec} ., 59^{\circ} \mathrm{C} \text { for } 1 \text { min., } 68^{\circ} \mathrm{C} \text { for } 10 \text { min.; } 4{ }^{\circ} \mathrm{C} \text { hold }\end{array}$ \\
\hline TS45/HBS-1B & 1 cycle: $95^{\circ} \mathrm{C}$ for $30 \mathrm{sec} . ; 25$ cycles: $95^{\circ} \mathrm{C}$ for $30 \mathrm{sec} ., 55^{\circ} \mathrm{C}$ for $1 \mathrm{~min} ., 68^{\circ} \mathrm{C}$ for $10 \mathrm{~min} . ;{ }^{\circ} \mathrm{C}$ hold \\
\hline TS45/HBS-2 & $\begin{array}{l}1 \text { cycle: } 95^{\circ} \mathrm{C} \text { for } 2 \min . ; 5 \text { cycles: } 95^{\circ} \mathrm{C} \text { for } 30 \mathrm{sec} ., 54^{\circ} \mathrm{C} \text { for } 1 \text { min., } 68^{\circ} \mathrm{C} \text { for } 10 \mathrm{~min} \text {.; } \\
25 \text { cycles: } 95^{\circ} \mathrm{C} \text { for } 30 \mathrm{sec} ., 59^{\circ} \mathrm{C} \text { for } 1 \text { min., } 68^{\circ} \mathrm{C} \text { for } 10 \text { min.; } 4^{\circ} \mathrm{C} \text { hold }\end{array}$ \\
\hline TS45/HBS-2B & 1 cycle: $95^{\circ} \mathrm{C}$ for $30 \mathrm{sec}$; 25 cycles: $95^{\circ} \mathrm{C}$ for $30 \mathrm{sec}$. $55^{\circ} \mathrm{C}$ for 1 min., $68^{\circ} \mathrm{C}$ for $10 \mathrm{~min} . ; 4^{\circ} \mathrm{C}$ hold \\
\hline TS45/HBS-3B & 1 cycle: $95^{\circ} \mathrm{C}$ for $30 \mathrm{sec} . ; 25$ cycles: $95^{\circ} \mathrm{C}$ for $30 \mathrm{sec} ., 55^{\circ} \mathrm{C}$ for 1 min., $68^{\circ} \mathrm{C}$ for $10 \mathrm{~min} . ;{ }^{\circ} \mathrm{C}$ hold \\
\hline TS45/HBS-4 & $\begin{array}{l}1 \text { cycle: } 95^{\circ} \mathrm{C} \text { for } 2 \min . ; 5 \text { cycles: } 95^{\circ} \mathrm{C} \text { for } 30 \mathrm{sec} ., 54^{\circ} \mathrm{C} \text { for } 1 \text { min., } 68^{\circ} \mathrm{C} \text { for } 10 \mathrm{~min} \text {; } \\
25 \text { cycles: } 95^{\circ} \mathrm{C} \text { for } 30 \mathrm{sec} ., 59^{\circ} \mathrm{C} \text { for } 1 \text { min., } 68^{\circ} \mathrm{C} \text { for } 10 \text { min.; } 4^{\circ} \mathrm{C} \text { hold }\end{array}$ \\
\hline TS45/HBS-5B & $\begin{array}{l}1 \text { cycle: } 95^{\circ} \mathrm{C} \text { for } 2 \mathrm{~min} . ; 5 \text { cycles: } 95^{\circ} \mathrm{C} \text { for } 30 \mathrm{sec} ., 54^{\circ} \mathrm{C} \text { for } 1 \text { min., } 68^{\circ} \mathrm{C} \text { for } 10 \mathrm{~min} \text {; } \\
25 \text { cycles: } 95^{\circ} \mathrm{C} \text { for } 30 \mathrm{sec} ., 59^{\circ} \mathrm{C} \text { for } 1 \mathrm{~min} ., 68^{\circ} \mathrm{C} \text { for } 10 \mathrm{~min} ; 4^{\circ} \mathrm{C} \text { hold }\end{array}$ \\
\hline TS45/HBS-6B & $\begin{array}{l}1 \text { cycle: } 95^{\circ} \mathrm{C} \text { for } 2 \mathrm{~min} . ; 5 \text { cycles: } 95^{\circ} \mathrm{C} \text { for } 30 \mathrm{sec} ., 54^{\circ} \mathrm{C} \text { for } 1 \mathrm{~min} ., 68^{\circ} \mathrm{C} \text { for } 10 \mathrm{~min} \text {; } \\
25 \text { cycles: } 95^{\circ} \mathrm{C} \text { for } 30 \mathrm{sec} ., 59^{\circ} \mathrm{C} \text { for } 1 \mathrm{~min} ., 68^{\circ} \mathrm{C} \text { for } 10 \mathrm{~min} ; 4^{\circ} \mathrm{C} \text { hold }\end{array}$ \\
\hline TS45/HBS-7 & $\begin{array}{l}1 \text { cycle: } 95^{\circ} \mathrm{C} \text { for } 2 \mathrm{~min} . ; 5 \text { cycles: } 95^{\circ} \mathrm{C} \text { for } 30 \mathrm{sec} ., 54^{\circ} \mathrm{C} \text { for } 1 \text { min., } 68^{\circ} \mathrm{C} \text { for } 10 \mathrm{~min} \text {.; } \\
25 \text { cycles: } 95^{\circ} \mathrm{C} \text { for } 30 \mathrm{sec} ., 59^{\circ} \mathrm{C} \text { for } 1 \text { min., } 68^{\circ} \mathrm{C} \text { for } 10 \mathrm{~min} . ; 4^{\circ} \mathrm{C} \text { hold }\end{array}$ \\
\hline TS45/HBS-7B & 1 cycle: $95^{\circ} \mathrm{C}$ for $30 \mathrm{sec} . ; 25$ cycles: $95^{\circ} \mathrm{C}$ for $30 \mathrm{sec} ., 55^{\circ} \mathrm{C}$ for $1 \mathrm{~min} ., 68^{\circ} \mathrm{C}$ for $10 \mathrm{~min} . ; 4^{\circ} \mathrm{C}$ hold \\
\hline TS45/HBS-8 & 1 cycle: $95^{\circ} \mathrm{C}$ for 2 min.; 25 cycles: $95^{\circ} \mathrm{C}$ for $30 \mathrm{sec} ., 63^{\circ} \mathrm{C}$ for $1 \mathrm{~min} ., 68^{\circ} \mathrm{C}$ for $10 \mathrm{~min} . ; 4^{\circ} \mathrm{C}$ hold \\
\hline
\end{tabular}


Cell Lines, Virus Production, Infection, and Titration. H1-BAG cells were used for virus production using the two plasmid system described in Chapter 2. NIH 3T3 cells were used to titer all virus as described in Chapter 2. In addition to the X-gal stain, one well of infected NIH 3 T3 cells in each set of 4 per virus was stained with basic fuchsin (Sigma), a positively charged dye that binds to negatively charged molecules, primarily the nucleic acid in the nucleus of cells.

SDS-PAGE and Western Blot Analysis. Viral pellets and producer cell lysates were collected as described in Chapter 2. Viral pellets were separated on a 10-20\% gradient SDS-PAGE gel and cell lysates were separated using an 8\% SDS-PAGE gel as described in Chapter 2. The separated proteins were transferred to nitrocellulose, detected, and developed as described in Chapter 2.

\section{Results}

Design of HBS Constructs. Table 4-3 shows an alignment of the protein sequences of the MLV heparin binding sites in MoMLV, FrMLV, and all HBS mutants. The FrMLV envelope has a shift of two amino acids in numbering when compared to that of MoMLV. HBS- 1 is a recapitulation of the PVC-211 $\mathrm{E}_{127} \mathrm{~K}$ mutation and HBS-2 and -3 are variations on that theme using the remaining two basic amino acids, arginine and histidine. The HBS mutations 4 and 5 change all the basic amino acids in the overlapping motifs to lysine and arginine respectively. Since a cluster of histidines may be incompatible with maintaining the alpha-helical structure of the HBS and might cause misfolding, the HBS- 6 and -7 mutations consist of histine-arginine and histidine-lysine combinations. The final mutation, HBS-8, incorporates the neutral amino acid alanine in place of all basic amino acids in both heparin binding motifs.

Fusion assay results (see Appendix B) indicated that virions expressing the del RBS envelope (see Chapter 3 for description) had the potential to infect at very low levels. In brief, a version of $\alpha$-complementation of the $E$. coli $\beta$-gal protein previously modified for use in mammalian cells [96-98] was employed to identify fusion occurring between cells expressing a particular receptor and cells expressing an envelope protein with the Rpeptide removed. Removal of the R-peptide enabled the envelope protein to initiate fusion and allowed mixing of cytoplasm. Once the cell contents were combined, proper folding of the $\beta$-gal protein required to process X-gal could be achieved by combination of the alpha and omega proteins expressed in each cell type [99, 100]. It was our thinking that any improvement of the heparin binding site should serve to increase this level of infection thus, we incorporated each of the afore mentioned HBS mutations into a del RBS background in addition to examining them in a wild type envelope background.. 
Table 4-3. Alignment of the Amino Acid Sequence of the Putative Heparin Binding Sites in Wild Type and Mutant Envelope Proteins.

\begin{tabular}{|c|c|}
\hline Name & Sequence \\
\hline MoMLV HBS & $\mathrm{C}_{119} \mathrm{PGP}^{1}$ HRPRESKSCGGP ${ }_{134}$ \\
\hline FrMLV HBS & $\mathrm{C}_{121}$ PGSHRPREAKSCGGP ${ }_{136}$ \\
\hline PVC-211 HBS & $\mathrm{C}_{121}$ PGSHRPRKAKSCGGP $_{136}$ \\
\hline HBS Motif 1 & XBBXBX \\
\hline HBS Motif 2 & XBBXBX \\
\hline Mutant HBS Motif & ХВВХВВХВХ \\
\hline HBS $1\left(\mathrm{E}_{127} \mathrm{~K}\right)$ & 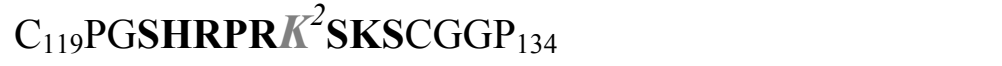 \\
\hline HBS $2\left(E_{127} R\right)$ & $\mathrm{C}_{119} \mathrm{PGSHRPR}$ RSKSCGGP ${ }_{134}$ \\
\hline HBS $3\left(\mathrm{E}_{127} \mathrm{H}\right)$ & $\mathrm{C}_{119} \mathrm{PGSHRPRHSKSCGGP}{ }_{134}$ \\
\hline HBS $4($ all $B=K)$ & $\mathrm{C}_{119} \mathrm{PGP} K K \mathbf{P} K K \mathbf{S K S C G G P}{ }_{134}$ \\
\hline HBS 5 (all B=R) & $\mathrm{C}_{119} \mathrm{PGP} \boldsymbol{R} \mathbf{R P R} \boldsymbol{R} \mathbf{S} \boldsymbol{R} \mathbf{S C G G P}{ }_{134}$ \\
\hline HBS 6 (all B=RorH) & $\mathrm{C}_{119}$ PGPHRPR HSRSCGGP ${ }_{134}$ \\
\hline HBS 7 (all B=KorH) & $\mathrm{C}_{119} \mathrm{PGPH} / \mathbf{P} K H \mathbf{S K S C G G P}{ }_{134}$ \\
\hline HBS $8($ all $B=A)$ & $\mathrm{C}_{119} \mathrm{PGP} A A \mathbf{P} A \mathbf{E S} A \mathbf{S C G G P}{ }_{134}$ \\
\hline
\end{tabular}

${ }^{1}$ Heparin binding motifs are indicated in boldface type. ${ }^{2}$ Amino acids altered as a result of nucleotide mutagenesis are enlarged, italicized, and shaded gray. 
HBS Mutations 4, 5, 7, and 8 Impede MoMLV Envelope Cleavage. HBS mutants 1, 2, 3 , and 6 expressed levels of SU (Figure 4-1) and gave infection (Figure 4-2) comparable to that of wild type MoMLV. These same variations when coupled with the del RBS mutation, retained their ability to express and process SU but could no longer infect NIH $3 \mathrm{~T} 3$ cells (Figure 4-2). HBS mutations 4, 5, 7, and 8 did not assemble their SU onto virions (Figure 4-1) which would be an evident reason for their failure to give infection (Figure 4-2). Analysis of producer cell lysates (Figure 4-1) indicated that, while the SU/TM precursor was expressed, it was not able to be cleaved. The data did not determine if the processing failure was due to a block in transiting the Golgi or sequestration of the cleavage site due to misfolding.

HBS Mutant Envelope Proteins 1, 2, 3, and 6 Influence Syncytia Phenotype. While the overall number of syncytia was not increased, the phenotype of syncytia formed by cells infected with wild type RBS/HBS mutants 1, 2, 3, and 6 differed from those formed during a wild type infection (Figure 4-3). Upon gross examination of micrographs, there appeared to be fewer cells involved in syncytia formed during wild type MoMLV infection when compared to those formed by cells infected with HBS-1, -2, -3, or -6. Additionally, there was an apparent decrease in the level of $\beta$-gal activity within those syncytia formed by the HBS mutant viruses. These results were not observed on cells infected with the del RBS/HBS-1, $-2,-3$, or -6 mutants.

\section{Discussion}

Wild type RBS and del RBS HBS mutants 4, 5, 7, and 8 were unable to cleave the precursor SU into its mature form. These mutants share mutations with accumulations of a basic amino acid, each of which differ in their level of steric hindrance. The net level of positive charge would have remained similar throughout all the HBS mutants, suggesting that other considerations caused the defect in precursor processing. Since this unexpected outcome occurred regardless of which basic residue was repeated in the motif, it appeared that the length and flexibility of the side chains in the repetitive motifs was not responsible for the defect. Alanine, although neutral, is a hydrophobic amino acid which, when asked to be present in a run, may have been prone to bury itself within the envelope structure rather than achieving the proper conformation. An exception to this correlation between the runs of the same amino acid and cleavage defect is HBS-7. This mutant contained a combination of charges within its HBS. The less bulky and more flexible side chain of lysine replaced arginine at positions 124 and $126\left(\mathrm{R}_{124} \mathrm{~K}\right.$ and $\left.\mathrm{R}_{126} \mathrm{~K}\right)$ and the aromatic histidine replaced glutamic acid at position $127\left(\mathrm{E}_{127} \mathrm{H}\right)$. The $\mathrm{E}_{127} \mathrm{H}$ mutation was tolerated in $\mathrm{HBS}-3$, but its combination with the $\mathrm{R}$ to $\mathrm{K}$ mutations appears unfavorable. Previous studies have shown that neither histidine nor long stretches of one basic amino acid are commonly incorporated in heparan binding motifs and that histidine in general poorly binds HSPG [101, 102].

The altered syncytia phenotype observed on cells infected with virions expressing wild type RBS and mutant HBS 1, 2, 3, or 6 may indicate that, once these virions bound 
A.

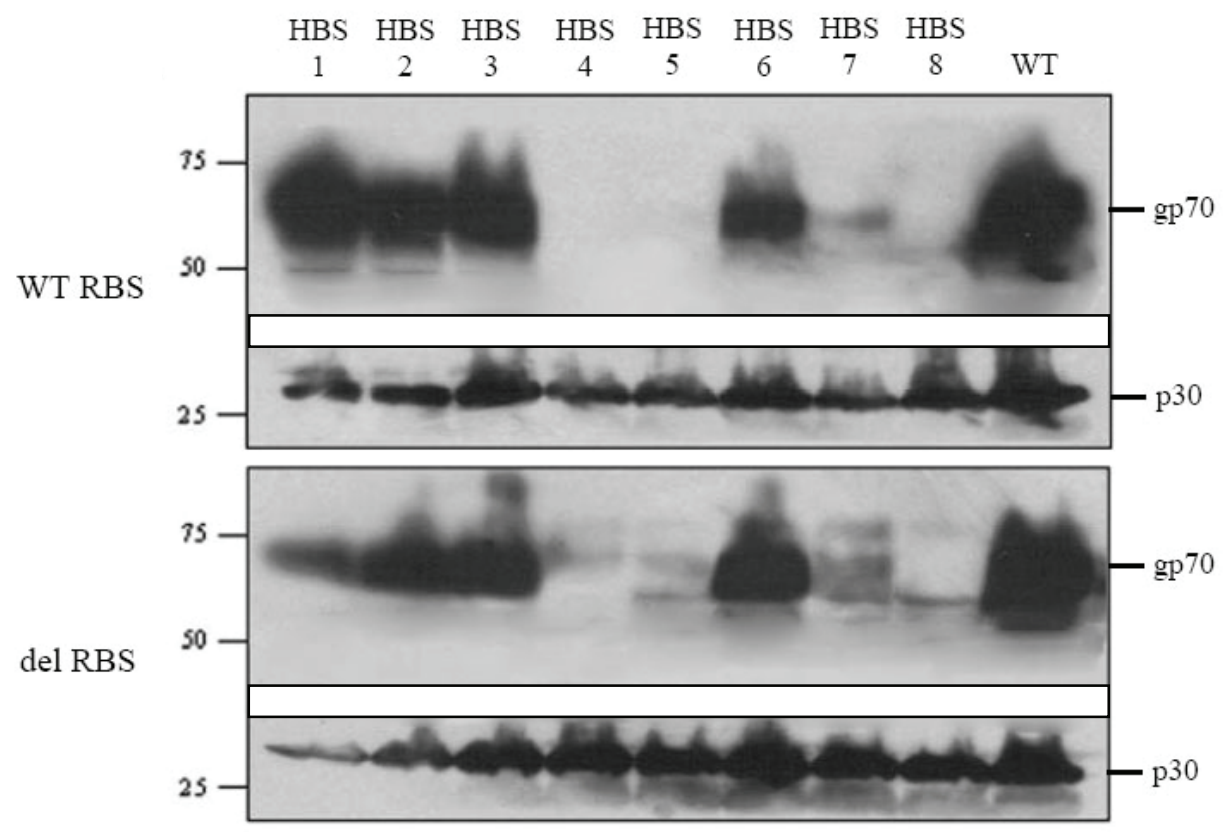

B.

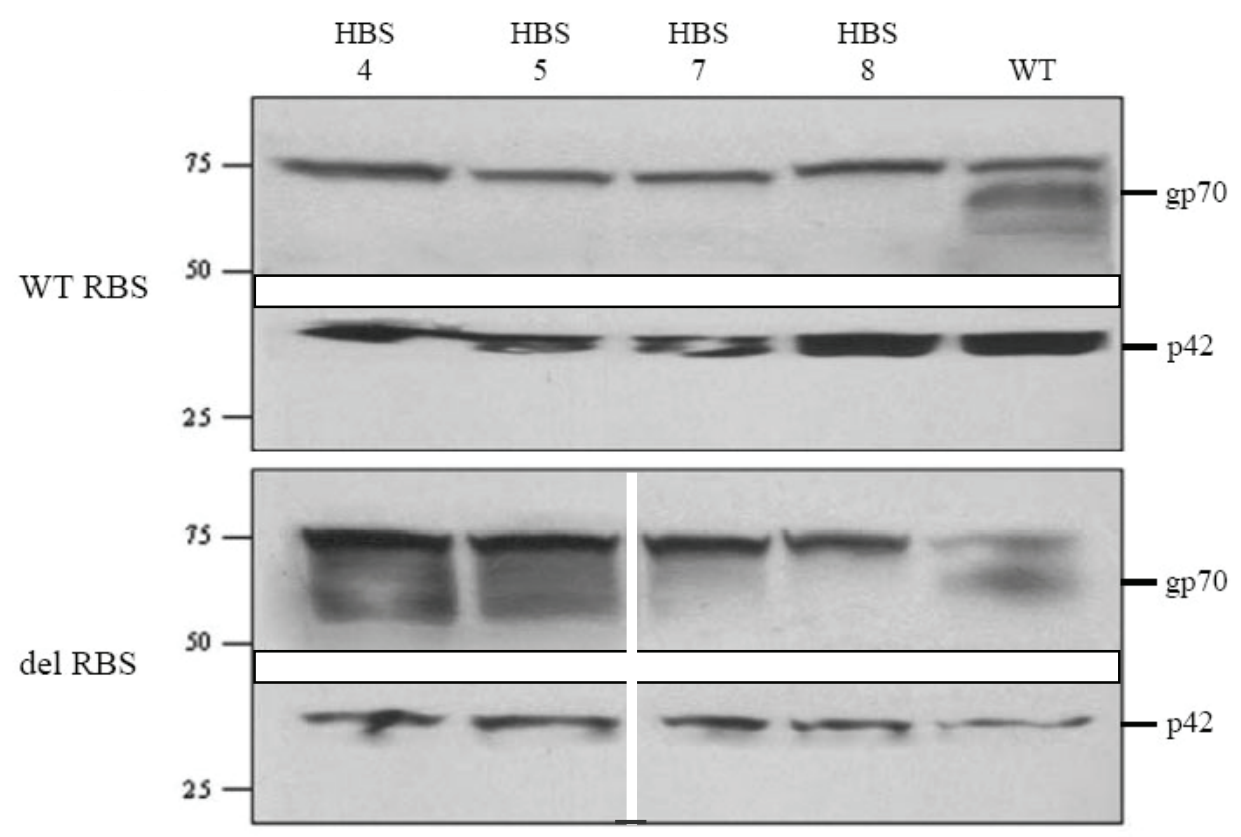

Figure 4-1. Western Blot Analysis of HBS Mutant Proteins. (A) Viral supernatant was pelleted and analyzed by SDS-PAGE and Western blot using antibody to the surface (gp70) protein of MoMLV envelope. Antibody to MoMLV capsid (p30) was used as a loading control. (B) Producer cell lysates were harvested once virus production was complete and analyzed by SDS-PAGE and Western blot using antibody to the surface (gp70) protein of MoMLV envelope. Antibody to actin (p42) was used as a loading control. 


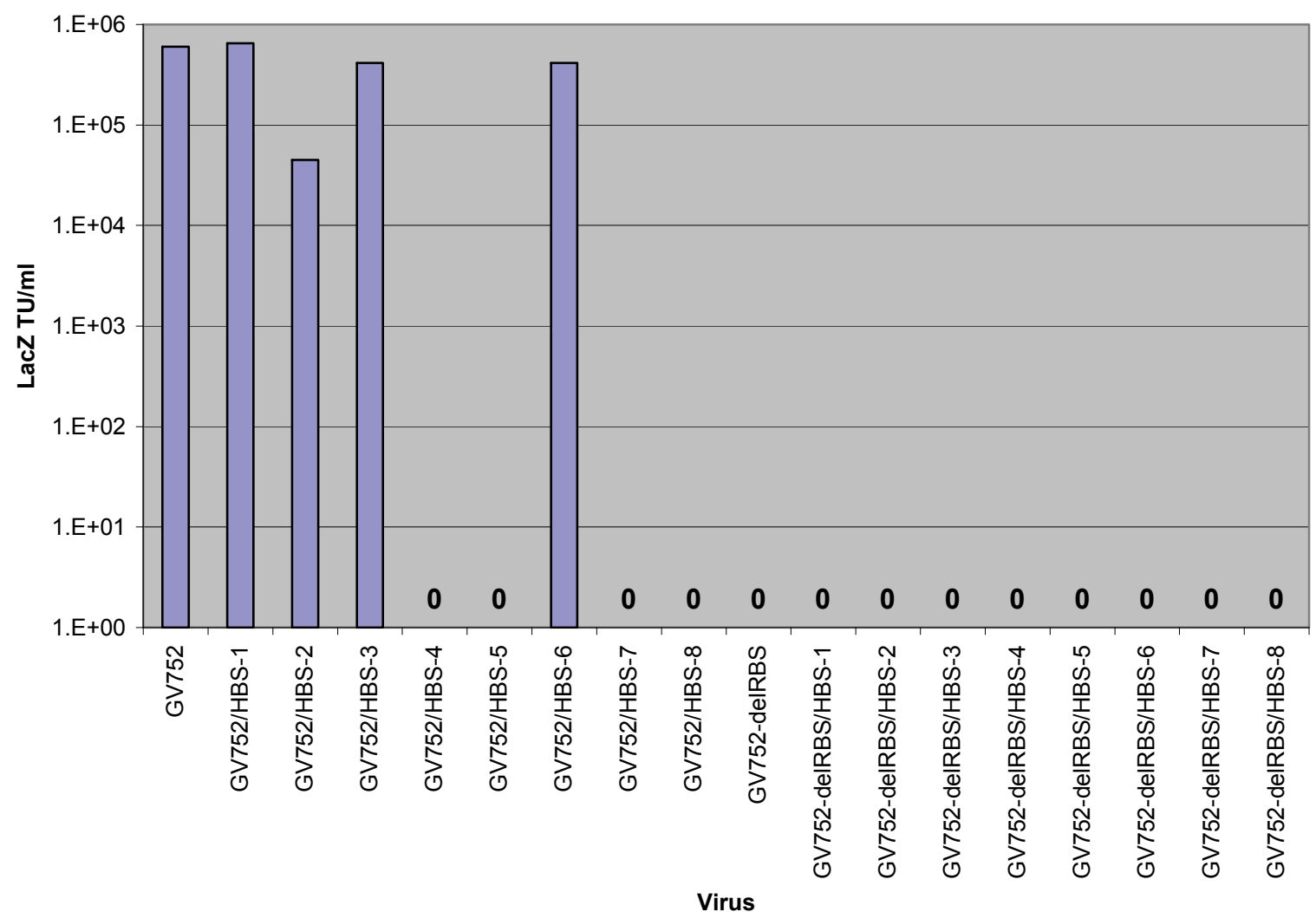

Figure 4-2. HBS Mutant Infection. NIH 3T3 cells were exposed to viral supernatant and infection was quantified by end-point dilution. The values of GV752, HBS-1, HBS-2, HBS-3, and HBS-6 are the average of results from 2 independent experiments normalized by their positive control (GV752) values. Experiment 1 values were: $6 \times 10^{5}, 4 \times 10^{5}, 6 \times 10^{4}, 8 \times 10^{5}$, and 8x10 . Experiment 2 values were: $6 \times 10^{5}, 9 \times 10^{5}, 3 \times 10^{4}, 3 \times 10^{4}$, and $1 \times 10^{5}$. 
A.

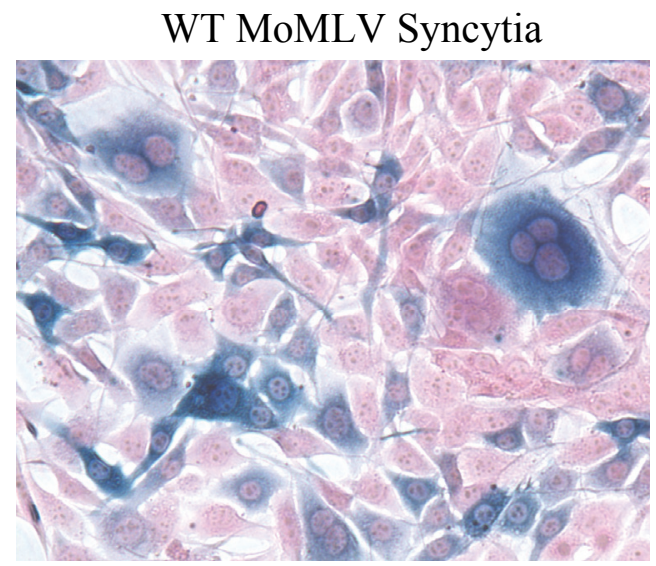

HBS Mutant Syncytia

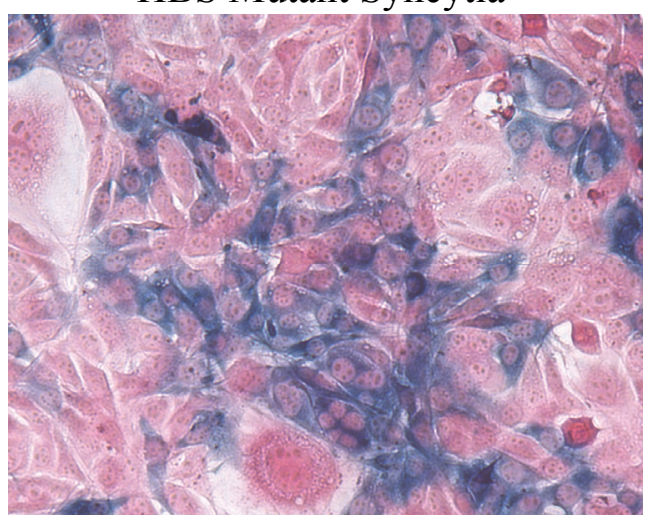

B.

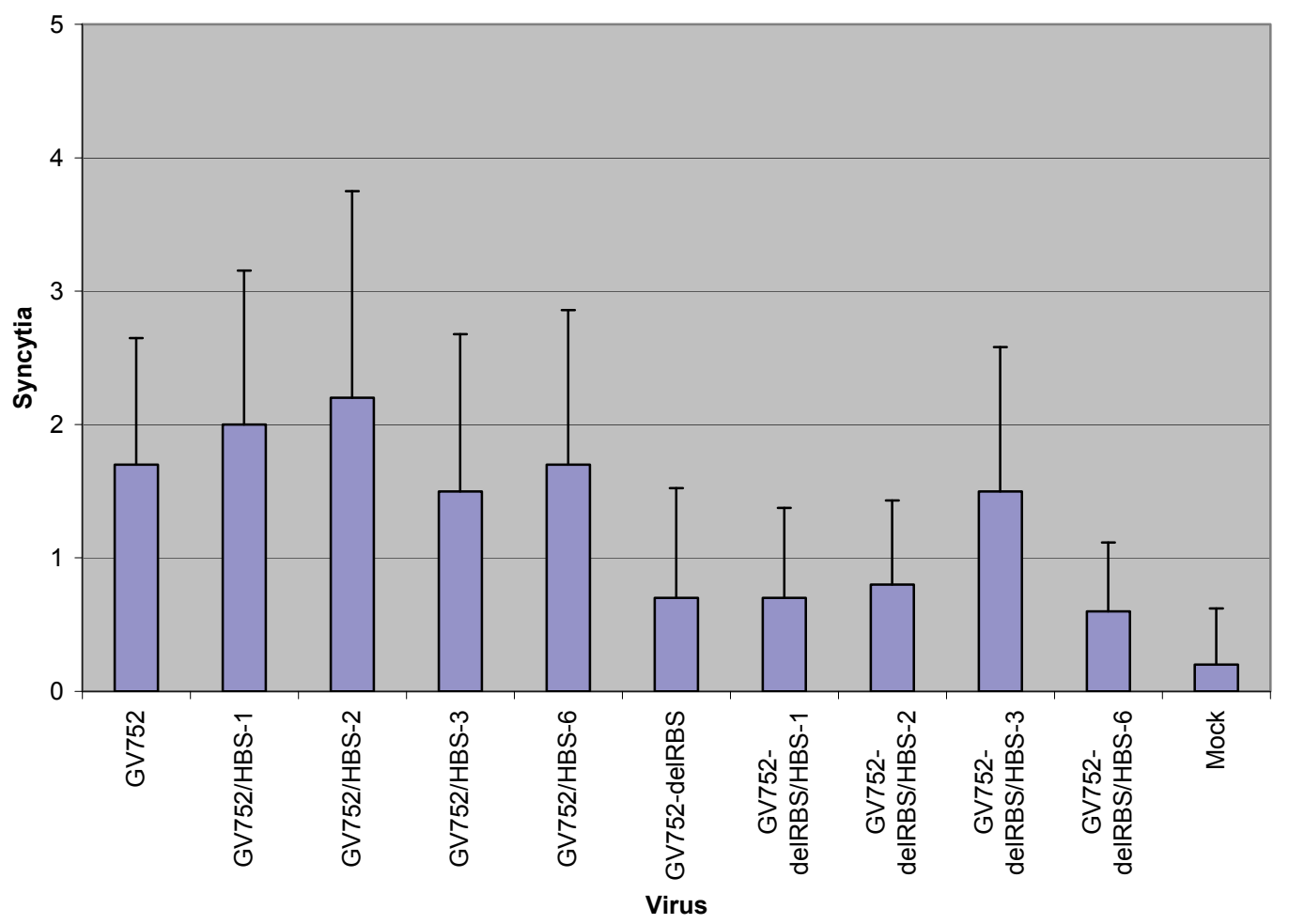

Figure 4-3. HBS Mutant Syncytia. (A) Infected NIH 3 T3 cells described in Figure 4-2, after having been fixed and stained for $\beta$-gal activity, were stained with basic fuchsin to further define cell nuclei. (B) Syncytia within ten contiguous fields captured using a Zeiss Axioplan2 epifluorescent microscope were counted and reported as individual units. One syncytia was defined as any cell with three or more nuclei within its plasma membrane. 
their receptor, they were able to induce fusion more swiftly and efficiently than those expressing the wild type protein. It is also possible that these HBS mutations increased heparan binding affinity to such an extent that a fusion "bridge" was permitted to form between several cells. A combination of these two possibilities may be the most likely explanation for this phenomenon. The available $\beta$-gal in the syncytia formed by these mutant virions may simply have been too dilute to be observed.

Human breast cancer cells have been shown to overexpress HSPG [103-106]. Based on this observation, an oncolytic, conditionally replicating adenoviral (CRAd) vector was recently developed and has been shown to be effective when delivered either intratumorally or intravenously [107]. HBS mutant viruses 1, 2, 3, and 6 may offer an increased preference for breast cancer cell and one or more of these mutated heparan binding sites may favor one cell type over another based on interactions between heparin versus heparan sulfates or other subtle differences within the heparan sulfates expressed on breast cancer cells. Breast cancer cell lines should be transiently transfected with DNA encoding for the ATRC-1 receptor and then exposed to wild type and HBS mutant virus. If heparin binding is indeed a useful indirect targeting method, the HBS mutant virus should infect at higher titers than wild type MoMLV.

In addition to infection data, virus binding assays should be performed on wild type and del RBS HBS mutants as well as wild type MoMLV to quantitate the level of virus binding to NIH $3 \mathrm{~T} 3$ cells and those breast cancer cell types that were infected by the wild type RBS HBS mutants both expressing and not expressing the ecotropic receptor. Briefly, cells would be exposed to virus and fixed in suspension. Then goat antiRauscher-gp70 (Quality Biotech, Inc.) antibody would be incubated with the fixed cell/virion complexes followed by donkey anti-goat antibody conjugated to Phycoerythrin (PE) (Jackson Laboratories, Inc.) and analyzed by flow cytometry. This assay would confirm infection data as well as demonstrate (through the del RBS HBS mutants and interactions with breast cancer cells not expressing ATRC-1) a receptor independent reaction and indicate small differences between each mutant.

The variations within these mutants may have $\mathrm{pH}$ advantages over each other. For example, the HBS-3 and -6 mutations may impart a low $\mathrm{pH}$ preference based on the lower $\mathrm{pKa}$ of the histidine ( $\mathrm{pKa}$ of 6.1) at position 127 as compared to lysine (pKa of 10.5 ) or arginine ( $\mathrm{pKa}$ of 12.5). This could be examined by lowering the $\mathrm{pH}$ during infection of breast cancer cell lines or NIH 3T3. These results would be best visualized by using the virus binding assay described above as the differences are likely to be minute. Since the tumor microenvironment tends to be one of acidic $\mathrm{pH}$ [108], HBS mutants 3 and 6 may more effectively infect within the tumor than HBS mutants 1 or 2 .

Prior to performance of these future studies, the NIH 3T3 cell line and a panel of breast cancer cell lines will need their levels of heparan sulfate expression quantified. The most straightforward way to accomplish this is by flow cytometry using an antibody to HSPG. In addition, the most effective method of transfection for each breast cancer cell line will need to be determined as was done for the MDA-MB-231 cell line in Appendix B. Finally, the wild type RBS and del RBS HBS mutants 1, 2, 3, and 6 will 
need to be analyzed to determine their ability to bind soluble heparan sulfate as described by Zhang, et. al. [85] since the del RBS constructs were unable to indicate any improvement in infection.

Finally, these mutant viruses should be examined in vivo. Recall that these HBS mutants contain the natural MoMLV RBS and that the PVC-211 FrMLV variant had extended its tropism to include BCEC [92]. This ability allowed the virus to cross the blood-brain barrier, but did not confer the ability to infect neurons or astroglia despite the presence of lesions in the central nervous system and subsequent neurodegenerative disease [91, 92]. A comparison of wild type MoMLV with HBS mutants 1, 2, 3, and 6 in neonatal rats as was done for PVC-211 and FrMLV would be an effective way to determine if these HBS mutants also have the ability to cross the blood-brain barrier and cause neurodegenerative disease. Mutants that lack the ability to cross the blood-brain barrier yet exhibited an enhanced affinity for HSPGs would be likely candidates for breast cancer cell targeted vectors. Those able to enter the brain might be uniquely qualified to target cancer cells in that area. 


\section{Chapter 5. Discussion}

Targeting one specific cell type within the context of the human body is a daunting task. Many attempts have been made to accomplish this important goal, all with limited or no success. The Sst/RBS chimera showed specificity for cells expressing Sst receptors in vitro, but will face a wider range of target cells in vivo. Humans have five genes encoding receptors with similar Sst binding affinity but different cell-signaling properties which are upregulated on certain cancer cells. These receptors are also expressed on pancreatic $\beta$-islet cells [109] as well as in the brain and numerous other tissues [110]. Similarly, CXCR-4, the receptor for SDF-1 $\alpha$, is overexpressed on some breast cancer cell types as well being naturally expressed on immune cells and in the brain [111]. These superfluous targets would be encountered by suicide gene therapy vectors, infected, and eliminated just as innocent bystander cells are during chemotherapy and radiation treatment.

Since a receptor candidate that is expressed exclusively on tumor cells will be a rare find, it is likely that multiple layers of targeting will be necessary to reduce the ability of these vectors to deliver their cargo to normal cells. In addition to the concepts of replacing the MoMLV RBS with a short ligand and manipulating the HBS, the PRR has demonstrated the ability to accept large insertions without interfering with envelope expression and assembly onto virions [21, 23, 31]. Ligands inserted into the PRR retain their ability to bind their receptor but are unable to induce all of the conformational changes necessary to mediate fusion of the viral envelope and the target cell membrane [31]. The combination of all three of these concepts into a single modified envelope protein might allow for a more cancer cell specific vector.

The epidermal growth factor (EGF) receptors (ErbB1 through 4) and SstR1 through 5 colocalize on several breast cancer cell lines [112]. Expanding on the Sst/RBS design by inserting the fifty-three amino acid EGF sequence into the PRR may increase the probability that cells expressing both these receptors would be infected rather than cells expressing SstR only. It should be noted, however, that Sst analogs have undergone clinical trials and demonstrated antiproliferative effects in breast cancer with limited side effects [113]. Additionally, clinical trials using cytotoxic analogs of Sst, bombesin, and luteinizing hormone-releasing hormone (LH-RH) were pending as of 2004 [114].

Another intriguing target for these retroviral vectors may prove to be cancer stem cells. It has been shown that certain brain, blood, and breast tumors are initiated and maintained by mutated progenitor cells [115-119] which are resistant to chemotherapeutic treatment [120]. These cells, in mice, have been associated with and identified by the expression of CD $44^{(+)}, \mathrm{CD} 24^{(-/ \text {low })}$, and ESA ${ }^{(+)}$(epithelial-specific antigen) on their surface [116]. Unfortunately, these particular antigens would make poor targets in vivo. For example, CD44 is expressed on most nucleated murine cells [121125] while CD24 is a common marker for the identification of immature cells of hematopoietic lineage and developing neurons [126-128] among other types of cells. The concept of repairing these defective cells ex vivo and returning them to their original 
location, however, is not outside the realm of possibility. The ligand for CD24 is Pselectin [129], the mature form of which is made up of 119 amino acids [130]. This ligand would be best suited to insertion in the MoMLV PRR. As for the RBS-replacing ligand, further characterization of these cells would need to be performed since the ligand for ESA is unknown and the expression of CD44 would likely be common to stem cells and their daughter cells.

Selection of the ligand used to replace the RBS remains an extremely difficult task. The identification of an effective high-throughput tool to screen potential ligands for tumor-specific binding capability would be extremely useful toward further development of this method of entry targeting. For example, the soluble GFP-tagged RBD developed in the Sitbon lab [131] could be utilized to ascertain ligands which allow proper envelope conformation and binding. Detection of GFP using flow cytometry and the gp-70 antibody would indicate which ligand-modified RBDs bound a particular target cell providing a method to screen many different RBDs and cell types efficiently. This process would be best orchestrated in two steps whereby ligand-modified RBDs would first be screened against a cell type known to express the target receptor (either transiently or stably) and those chimeric envelope proteins showing promise in this area would be screened against cancer cell lines and primary tumor cells. Virus production would ultimately be required to determine the ability of these envelope chimeras to induce fusion and infect their target cell, but many possibilities and combinations could be eliminated prior to that step through the use of this type of assay.

One issue to consider while teasing out the useful chimeric RBDs is the possibility of cancer cells having one or more downstream blocks to retroviral infection. This research group has seen evidence of this type of impediment when working with neuroblastoma cell lines (F. Li and L. Albritton, unpublished results). Amphotrophic MLV (A-MLV) enters cells using the PiT-2 receptor, a sodium-dependent potassium transporter [132] which is known to be expressed on a variety of human cell types. A-MLV produced using our $\beta$-gal reporter system could be used to screen cancer cell lines and primary tumor cells. Those tumor cells showing levels of infection comparable to human 293 cells by the A-MLV would be good candidates for target cells lacking downstream blocks to entry. Any cell lines unable to be infected by A-MLV would need their level of PiT-2 receptor expression evaluated by either flow cytometry or Western blot analysis before jumping to the downstream block conclusion. Another, more reliable, indicator of a downstream block to infection would be an infection using MLV particles pseudotyped with the vesicular stomatitus virus G protein (VSV-G). The VSV-G protein is known to mediate entry into an extremely broad range of cell types, therefore any lack of infection could more reasonably be contributed to a downstream block and no evaluation of receptor expression would be required.

It is incredibly time consuming to produce enough chimeric MoMLV-based retroviral vector to ensure infection of its target cells. For example, unconcentrated Sst/RBS virus infected only approximately $50 \%$ of cells expressing high levels of SstR2 [46]. This same virus was also rendered non-infectious after storage at $-80^{\circ} \mathrm{C}$. To increase infection, a method of concentrating these chimeras without damaging them must be 
developed. Here is an area where enhancing the HBS might impart an advantage beyond targeting. Past studies have shown that the heparin binding properties of recombinant adeno-associated virus (rAAV) [133] and MoMLV particles pseudotyped with the VSV$\mathrm{G}$ envelope protein are amenable to purification by affinity chromatography and infectious particles were recovered under mild elution conditions (neutral $\mathrm{pH}$ and $0.35 \mathrm{M}$ $\mathrm{NaCl})[134,135]$. This method would serve to decrease the number of purification steps required and increase yield thus reducing the amount of time and effort required to produce MoMLV-based vectors.

While retroviral vectors are unlikely to replace conventional cancer treatments, they could be useful as a means to ensure a more complete eradication of cancerous cells after treatment with chemotherapy or radiation. This might allow for a reduction in the amount of the conventional treatment necessary and improve the patient's quality of life by decreasing side effects. Incidentally, the immune suppression commonly resulting from treatment with chemotherapy or radiation therapy would serve to enhance infection with retroviral vectors. Retroviral vectors also have the potential to serve as effective diagnostic and prognostic tools. For example, better visualization of cancer cells might be accomplished through delivery of a luminescent expression gene for more exact removal and tumor load calculation.

In conclusion, the innovative design of Sst/RBS is a wonderful start down an arduous path of selecting ligands targeted to limited cell types and identifying those with the capacity to mediate virus attachment and entry. Combining this design with additional ligands inserted in the PRR and an enhanced HBS may improve the likelihood of delivery of a gene of interest to its intended target cells and the enhanced HBS may improve the amount of virus available for delivery. Both of these are steps in the right direction towards the development of an effective retroviral vector. 


\section{List of References}

1. Moreland, J.L., et al., The Molecular Biology Toolkit (MBT): A Modular Platform for Developing Molecular Visualization Applications. BMC Bioinformatics, 2005. 6: p. 21-28.

2. Cone, R.D. and R.C. Mulligan, High-Efficiency Gene Transfer into Mammalian Cells: Generation of Helper-Free Recombinant Retrovirus with Broad Mammalian Host Range. Proc Natl Acad Sci U S A, 1984. 81(20): p. 6349-6353.

3. Anderson, W.F., September 14, 1990: The Beginning. Hum Gene Ther, 1990. 1(4): p. 371-372.

4. $\quad$ Cavazzana-Calvo, M., et al., Gene Therapy of Human Severe Combined Immunodeficiency (SCID)-X1 Disease. Science, 2000. 288(5466): p. 669-672.

5. Pages, J.C. and T. Bru, Toolbox for Retrovectorologists. J Gene Med, 2004. 6 Suppl 1: p. S67-82.

6. Hunter, E. and R. Swanstrom, Retrovirus Envelope Glycoproteins. Curr Top Microbiol Immunol, 1990. 157: p. 187-253.

7. Barquinero, J., H. Eixarch, and M. Perez-Melgosa, Retroviral Vectors: New Applications for an Old Tool. Gene Ther, 2004. 11 Suppl 1: p. S3-9.

8. Kim, J.W., et al., Transport of Cationic Amino Acids by the Mouse Ecotropic Retrovirus Receptor. Nature, 1991. 352(6337): p. 725-728.

9. Albritton, L.M., et al., The Human Cationic Amino Acid Transporter (ATRC1): Physical and Genetic Mapping to 13q12-q14. Genomics, 1992. 12(3): p. 430-434.

10. Albritton, L.M., et al., Envelope-Binding Domain in the Cationic Amino Acid Transporter Determines the Host Range of Ecotropic Murine Retroviruses. J Virol, 1993. 67(4): p. 2091-2096.

11. Malhotra, S., et al., Analysis of the Murine Ecotropic Leukemia Virus Receptor Reveals a Common Biochemical Determinant on Diverse Cell Surface Receptors That Is Essential to Retrovirus Entry. J Virol, 1996. 70(1): p. 321-326.

12. Qian, Z., et al., Identification of a Critical Basic Residue on the Ecotropic Murine Leukemia Virus Receptor. J Virol, 2003. 77(15): p. 8596-8601.

13. Waehler, R., S.J. Russell, and D.T. Curiel, Engineering Targeted Viral Vectors for Gene Therapy. Nat Rev Genet, 2007. 8(8): p. 573-587.

14. Legrain, P., B. Goud, and G. Buttin, Increase of Retroviral Infection in Vitro by the Binding of Antiretroviral Antibodies. J Virol, 1986. 60(3): p. 1141-1144.

15. Goud, B., P. Legrain, and G. Buttin, Antibody-Mediated Binding of a Murine Ecotropic Moloney Retroviral Vector to Human Cells Allows Internalization but Not the Establishment of the Proviral State. Virology, 1988. 163(1): p. 251-254.

16. Roux, P., P. Jeanteur, and M. Piechaczyk, A Versatile and Potentially General Approach to the Targeting of Specific Cell Types by Retroviruses: Application to the Infection of Human Cells by Means of Major Histocompatibility Complex Class I and Class II Antigens by Mouse Ecotropic Murine Leukemia VirusDerived Viruses. Proc Natl Acad Sci U S A, 1989. 86(23): p. 9079-9083.

17. Neda, H., C.H. Wu, and G.Y. Wu, Chemical Modification of an Ecotropic Murine Leukemia Virus Results in Redirection of Its Target Cell Specificity. J Biol Chem, 1991. 266(22): p. 14143-14146. 
18. Kasahara, N., A.M. Dozy, and Y.W. Kan, Tissue-Specific Targeting of Retroviral Vectors through Ligand-Receptor Interactions. Science, 1994. 266(5189): p. 1373-1376.

19. Cosset, F.L., et al., Retroviral Retargeting by Envelopes Expressing an NTerminal Binding Domain. J Virol, 1995. 69(10): p. 6314-6322.

20. Lorimer, I.A. and S.J. Lavictoire, Targeting Retrovirus to Cancer Cells Expressing a Mutant EGF Receptor by Insertion of a Single Chain Antibody Variable Domain in the Envelope Glycoprotein Receptor Binding Lobe. J Immunol Methods, 2000. 237(1-2): p. 147-157.

21. Wu, B.W., et al., Identification of Regions in the Moloney Murine Leukemia Virus SU Protein That Tolerate the Insertion of an Integrin-Binding Peptide. Virology, 2000. 269(1): p. 7-17.

22. Bae, Y., S.M. Kingsman, and A.J. Kingsman, Functional Dissection of the Moloney Murine Leukemia Virus Envelope Protein gp70. J Virol, 1997. 71(3): p. 2092-2099.

23. Weimin Wu, B., et al., Characterization of the Proline-Rich Region of Murine Leukemia Virus Envelope Protein. J Virol, 1998. 72(7): p. 5383-5391.

24. Zavorotinskaya, T. and L.M. Albritton, Suppression of a Fusion Defect by Second Site Mutations in the Ecotropic Murine Leukemia Virus Surface Protein. J Virol, 1999. 73(6): p. 5034-5042.

25. Panda, B.R., S.M. Kingsman, and A.J. Kingsman, Mutational Analysis of the Putative Receptor-Binding Domain of Moloney Murine Leukemia Virus Glycoprotein gp70. Virology, 2000. 273(1): p. 90-100.

26. Lavillette, D., et al., Relationship between SU Subdomains That Regulate the Receptor-Mediated Transition from the Native (Fusion-Inhibited) to the FusionActive Conformation of the Murine Leukemia Virus Glycoprotein. J Virol, 2002. 76(19): p. 9673-9685.

27. Lu, C.W. and M.J. Roth, Functional Interaction between the $N$-and C-Terminal Domains of Murine Leukemia Virus Surface Envelope Protein. Virology, 2003. 310(1): p. 130-140.

28. Lu, C.W. and M.J. Roth, Role of the Mutation Q252R in Activating Membrane Fusion in the Murine Leukemia Virus Surface Envelope Protein. J Virol, 2003. 77(20): p. 10841-10849.

29. Zavorotinskaya, T., et al., A Point Mutation in the Binding Subunit of a Retroviral Envelope Protein Arrests Virus Entry at Hemifusion. J Virol, 2004. 78(1): p. 473481.

30. Qian, Z. and L.M. Albritton, An Aromatic Side Chain Is Required at Residue 8 of SU for Fusion of Ecotropic Murine Leukemia Virus. J Virol, 2004. 78(1): p. 508512.

31. Ryu, B.Y., et al., The Block to Membrane Fusion Differs with the Site of Ligand Insertion in Modified Retroviral Envelope Proteins. J Gen Virol, 2008. 89(Pt 4): p. 1049-1058.

32. Gliniak, B.C., et al., Disulfide Bonding Controls the Processing of Retroviral Envelope Glycoproteins. J Biol Chem, 1991. 266(34): p. 22991-22997. 
33. Zavorotinskaya, T. and L.M. Albritton, Failure to Cleave Murine Leukemia Virus Envelope Protein Does Not Preclude Its Incorporation in Virions and Productive Virus-Receptor Interaction. J Virol, 1999. 73(7): p. 5621-5629.

34. Green, N., et al., Sequence-Specific Antibodies Show That Maturation of Moloney Leukemia Virus Envelope Polyprotein Involves Removal of a COOH-Terminal Peptide. Proc Natl Acad Sci U S A, 1981. 78(10): p. 6023-6027.

35. Henderson, L.E., et al., Quantitative Separation of Murine Leukemia Virus Proteins by Reversed-Phase High-Pressure Liquid Chromatography Reveals Newly Described Gag and Env Cleavage Products. J Virol, 1984. 52(2): p. 492500.

36. Ragheb, J.A. and W.F. Anderson, $p H$-Independent Murine Leukemia Virus Ecotropic Envelope-Mediated Cell Fusion: Implications for the Role of the $R$ Peptide and P12e Tm in Viral Entry. J Virol, 1994. 68(5): p. 3220-3231.

37. Rein, A., et al., Function of the Cytoplasmic Domain of a Retroviral Transmembrane Protein: P15e-P2e Cleavage Activates the Membrane Fusion Capability of the Murine Leukemia Virus Env Protein. J Virol, 1994. 68(3): p. 1773-1781.

38. Heard, J.M. and O. Danos, An Amino-Terminal Fragment of the Friend Murine Leukemia Virus Envelope Glycoprotein Binds the Ecotropic Receptor. J Virol, 1991. 65(8): p. 4026-4032.

39. Battini, J.L., J.M. Heard, and O. Danos, Receptor Choice Determinants in the Envelope Glycoproteins of Amphotropic, Xenotropic, and Polytropic Murine Leukemia Viruses. J Virol, 1992. 66(3): p. 1468-1475.

40. Linder, M., et al., Localization of the Intrachain Disulfide Bonds of the Envelope Glycoprotein 71 from Friend Murine Leukemia Virus. Eur J Biochem, 1992. 203(1-2): p. 65-73.

41. Battini, J.L., O. Danos, and J.M. Heard, Receptor-Binding Domain of Murine Leukemia Virus Envelope Glycoproteins. J Virol, 1995. 69(2): p. 713-719.

42. MacKrell, A.J., et al., Identification of a Subdomain in the Moloney Murine Leukemia Virus Envelope Protein Involved in Receptor Binding. J Virol, 1996. 70(3): p. 1768-1774.

43. Fass, D., et al., Structure of a Murine Leukemia Virus Receptor-Binding Glycoprotein at 2.0 Angstrom Resolution. Science, 1997. 277(5332): p. 16621666.

44. Barnett, A.L. and J.M. Cunningham, Receptor Binding Transforms the Surface Subunit of the Mammalian C-Type Retrovirus Envelope Protein from an Inhibitor to an Activator of Fusion. J Virol, 2001. 75(19): p. 9096-9105.

45. Davey, R.A., Y. Zuo, and J.M. Cunningham, Identification of a Receptor-Binding Pocket on the Envelope Protein of Friend Murine Leukemia Virus. J Virol, 1999. 73(5): p. 3758-3763.

46. Li F., R.B.Y., Selders M. and Albritton L.M, A Rational Design for Chimeric Retroviral Envelope Protein That Gives Transduction of a Specific Cell Type. Unpublished Work, 2008.

47. Davey, R.A., et al., In Vitro Binding of Purified Murine Ecotropic Retrovirus Envelope Surface Protein to Its Receptor, MCAT-1. J Virol, 1997. 71(11): p. 8096-8102. 
48. Cunningham, S., et al., A Gene Therapy Approach to Enhance the Targeted Radiotherapy of Neuroblastoma. Med Pediatr Oncol, 2000. 35(6): p. 708-711.

49. Li, P.X., et al., Differential Chemosensitivity of Breast Cancer Cells to Ganciclovir Treatment Following Adenovirus-Mediated Herpes Simplex Virus Thymidine Kinase Gene Transfer. Cancer Gene Ther, 1999. 6(2): p. 179-190.

50. Su, Z.Z., et al., The Cancer Growth Suppressor Gene Mda-7 Selectively Induces Apoptosis in Human Breast Cancer Cells and Inhibits Tumor Growth in Nude Mice. Proc Natl Acad Sci U S A, 1998. 95(24): p. 14400-14405.

51. Muggia FM, A.D., Bader JL, et al. Breast Cancer Treatment-National Cancer Institute. [Web Page] 2008 April 4, 2008 [cited 2008 April 29, 2008]; Treatment Option Overview (Patient Information)].

52. Muggia FM, A.D., Bader JL, et al. Radiation Therapy Fact Sheets - National Cancer Institute. [Web Page] 2008 June 29, 2007 [cited 2008 April 29, 2008]; Radiation Therapy Fact Sheets].

53. Muggia FM, A.D., Bader JL, et al. Chemotherapy and You: Support for People with Cancer - National Cancer Institute. 2008 June 29, 2007 [cited 2008 April 29, 2008]; Chemotherapy Side Effects].

54. Katane, M., et al., Factors Affecting the Direct Targeting of Murine Leukemia Virus Vectors Containing Peptide Ligands in the Envelope Protein. EMBO Rep, 2002. 3(9): p. 899-904.

55. Shirozu, M., et al., Structure and Chromosomal Localization of the Human Stromal Cell-Derived Factor 1 (SDF1) Gene. Genomics, 1995. 28(3): p. 495-500.

56. Bleul, C.C., et al., A Highly Efficacious Lymphocyte Chemoattractant, Stromal Cell-Derived Factor 1 (SDF-1). J Exp Med, 1996. 184(3): p. 1101-1109.

57. Nagasawa, T., et al., Defects of B-Cell Lymphopoiesis and Bone-Marrow Myelopoiesis in Mice Lacking the CXC Chemokine PBSF/SDF-1. Nature, 1996. 382(6592): p. 635-638.

58. Baggiolini, M., B. Dewald, and B. Moser, Human Chemokines: An Update. Annu Rev Immunol, 1997. 15: p. 675-705.

59. Federsppiel, B., et al., Molecular Cloning of the cDNA and Chromosomal Localization of the Gene for a Putative Seven-Transmembrane Segment (7-TMS) Receptor Isolated from Human Spleen. Genomics, 1993. 16(3): p. 707-712.

60. Loetscher, M., et al., Cloning of a Human Seven-Transmembrane Domain Receptor, LESTR, That Is Highly Expressed in Leukocytes. J Biol Chem, 1994. 269(1): p. 232-237.

61. Bleul, C.C., et al., The Lymphocyte Chemoattractant SDF-1 Is a Ligand for LESTR/Fusin and Blocks HIV-1 Entry. Nature, 1996. 382(6594): p. 829-833.

62. Muller, A., et al., Involvement of Chemokine Receptors in Breast Cancer Metastasis. Nature, 2001. 410(6824): p. 50-56.

63. Liang, Z., et al., Inhibition of Breast Cancer Metastasis by Selective Synthetic Polypeptide against CXCR4. Cancer Res, 2004. 64(12): p. 4302-4308.

64. Liang, Z., et al., CXCR4/CXCL12 Axis Promotes VEGF-Mediated Tumor Angiogenesis through Akt Signaling Pathway. Biochem Biophys Res Commun, 2007. 359(3): p. 716-722. 
65. Lee, B.C., et al., Involvement of the Chemokine Receptor CXCR4 and Its Ligand Stromal Cell-Derived Factor 1 Alpha in Breast Cancer Cell Migration through Human Brain Microvascular Endothelial Cells. Mol Cancer Res, 2004. 2(6): p. 327-338.

66. Strausberg, R.L., et al., Generation and Initial Analysis of More Than 15,000 Full-Length Human and Mouse cDNA Sequences. Proc Natl Acad Sci U S A, 2002. 99(26): p. 16899-16903.

67. Morgenstern, J.P. and H. Land, Advanced Mammalian Gene Transfer: High Titre Retroviral Vectors with Multiple Drug Selection Markers and a Complementary Helper-Free Packaging Cell Line. Nucleic Acids Research, 1990. 18(12): p. 3587-3596.

68. Crump, M.P., et al., Solution Structure and Basis for Functional Activity of Stromal Cell-Derived Factor-1; Dissociation of CXCR4 Activation from Binding and Inhibition of HIV-1. Embo J, 1997. 16(23): p. 6996-7007.

69. Guex, N. and M.C. Peitsch, Swiss-Model and the Swiss-PDB viewer: An Environment for Comparative Protein Modeling. Electrophoresis, 1997. 18(15): p. 2714-2723.

70. Sayle, R.A. and E.J. Milner-White, Rasmol: Biomolecular Graphics for All. Trends Biochem Sci, 1995. 20(9): p. 374.

71. Bernstein, H.J., Recent Changes to Rasmol, Recombining the Variants. Trends Biochem Sci, 2000. 25(9): p. 453-455.

72. Loetscher, P., et al., N-Terminal Peptides of Stromal Cell-Derived Factor-1 with CXC Chemokine Receptor 4 Agonist and Antagonist Activities. J Biol Chem, 1998. 273(35): p. 22279-22283.

73. Sakaida, H., et al., T-Tropic Human Immunodeficiency Virus Type 1 (HIV-1)Derived V3 Loop Peptides Directly Bind to CXCR-4 and Inhibit T-Tropic HIV-1 Infection. J Virol, 1998. 72(12): p. 9763-9770.

74. Tachibana, K., et al., CXCR4/Fusin Is Not a Species-Specific Barrier in Murine Cells for HIV-1 Entry. J Exp Med, 1997. 185(10): p. 1865-1870.

75. Rauly, I., et al., Induction of a Negative Autocrine Loop by Expression of Sst 2 Somatostatin Receptor in NIH 3 T3 Cells. J Clin Invest, 1996. 97(8): p. 18741883.

76. Reardon, D.B., et al., Activation of a Protein Tyrosine Phosphatase and Inactivation of RAF-1 by Somatostatin. Biochem J, 1996. 314 ( Pt 2): p. 401-404.

77. Cardin, A.D. and H.J. Weintraub, Molecular Modeling of ProteinGlycosaminoglycan Interactions. Arteriosclerosis, 1989. 9(1): p. 21-32.

78. Hileman, R.E., et al., Glycosaminoglycan-Protein Interactions: Definition of Consensus Sites in Glycosaminoglycan Binding Proteins. Bioessays, 1998. 20(2): p. 156-167.

79. WuDunn, D. and P.G. Spear, Initial Interaction of Herpes Simplex Virus with Cells Is Binding to Heparan Sulfate. J Virol, 1989. 63(1): p. 52-58.

80. Neyts, J., et al., Sulfated Polymers Inhibit the Interaction of Human Cytomegalovirus with Cell Surface Heparan Sulfate. Virology, 1992. 189(1): p. 48-58. 
81. Secchiero, P., et al., Role of the Extracellular Domain of Human Herpesvirus 7 Glycoprotein B in Virus Binding to Cell Surface Heparan Sulfate Proteoglycans. J Virol, 1997. 71(6): p. 4571-4580.

82. Krusat, T. and H.J. Streckert, Heparin-Dependent Attachment of Respiratory Syncytial Virus (RSV) to Host Cells. Arch Virol, 1997. 142(6): p. 1247-1254.

83. Patel, M., et al., Cell-Surface Heparan Sulfate Proteoglycan Mediates HIV-1 Infection of T-Cell Lines. AIDS Res Hum Retroviruses, 1993. 9(2): p. 167-174.

84. Mondor, I., S. Ugolini, and Q.J. Sattentau, Human Immunodeficiency Virus Type 1 Attachment to HeLa CD4 Cells Is CD4 Independent and gp120 Dependent and Requires Cell Surface Heparans. J Virol, 1998. 72(5): p. 3623-3634.

85. Zhang, Y., et al., Identification of the Receptor Binding Domain of the Mouse Mammary Tumor Virus Envelope Protein. J Virol, 2003. 77(19): p. 10468-10478.

86. Jinno-Oue, A., M. Oue, and S.K. Ruscetti, A Unique Heparin-Binding Domain in the Envelope Protein of the Neuropathogenic PVC-211 Murine Leukemia Virus May Contribute to Its Brain Capillary Endothelial Cell Tropism. J Virol, 2001. 75(24): p. 12439-12445.

87. Walker, S.J., et al., Heparin Binds to Murine Leukemia Virus and Inhibits EnvIndependent Attachment and Infection. J Virol, 2002. 76(14): p. 6909-6918.

88. Dechecchi, M.C., et al., Heparan Sulfate Glycosaminoglycans Are Involved in Adenovirus Type 5 and 2-Host Cell Interactions. Virology, 2000. 268(2): p. 382390.

89. Summerford, C. and R.J. Samulski, Membrane-Associated Heparan Sulfate Proteoglycan Is a Receptor for Adeno-Associated Virus Type 2 Virions. J Virol, 1998. 72(2): p. 1438-1445.

90. Jackson, T., et al., Efficient Infection of Cells in Culture by Type O Foot-andMouth Disease Virus Requires Binding to Cell Surface Heparan Sulfate. J Virol, 1996. 70(8): p. 5282-5287.

91. Kai, K. and T. Furuta, Isolation of Paralysis-Inducing Murine Leukemia Viruses from Friend Virus Passaged in Rats. J Virol, 1984. 50(3): p. 970-973.

92. Hoffman, P.M., et al., Cellular Tropism and Localization in the Rodent Nervous System of a Neuropathogenic Variant of Friend Murine Leukemia Virus. Lab Invest, 1992. 67(3): p. 314-321.

93. Masuda, M., et al., Effects of Subtle Changes in the SU Protein of Ecotropic Murine Leukemia Virus on Its Brain Capillary Endothelial Cell Tropism and Interference Properties. Virology, 1996. 215(2): p. 142-151.

94. Masuda, M., et al., Capillary Endothelial Cell Tropism of PVC-211 Murine Leukemia Virus and Its Application for Gene Transduction. J Virol, 1997. 71(8): p. 6168-6173.

95. Masuda, M., et al., Molecular Mechanism for Retroviral Neuropathogenesis: Possible Involvement of Capillary Endothelial Cells. Leukemia, 1997. 11 Suppl 3: p. 233-235.

96. Moosmann, P. and S. Rusconi, Alpha Complementation of LacZ in Mammalian Cells. Nucleic Acids Res, 1996. 24(6): p. 1171-1172.

97. Holland, A.U., et al., Alpha-Complementation Assay for HIV Envelope Glycoprotein-Mediated Fusion. Virology, 2004. 319(2): p. 343-352. 
98. Rossi, F.M., et al., Monitoring Protein-Protein Interactions in Live Mammalian Cells by Beta-Galactosidase Complementation. Methods Enzymol, 2000. 328: p. 231-251.

99. Gallagher, C.N., N.J. Roth, and R.E. Huber, A Rapid Method for the Purification of Large Amounts of an Alpha-Complementing Peptide Derived from BetaGalactosidase (E. Coli). Prep Biochem, 1994. 24(3-4): p. 297-304.

100. Jacobson, R.H., et al., Three-Dimensional Structure of Beta-Galactosidase from E. Coli. Nature, 1994. 369(6483): p. 761-766.

101. Caldwell, E.E., et al., Importance of Specific Amino Acids in Protein Binding Sites for Heparin and Heparan Sulfate. Int J Biochem Cell Biol, 1996. 28(2): p. 203216.

102. Fromm, J.R., et al., Pattern and Spacing of Basic Amino Acids in Heparin Binding Sites. Arch Biochem Biophys, 1997. 343(1): p. 92-100.

103. Matsuda, K., et al., Glypican-1 Is Overexpressed in Human Breast Cancer and Modulates the Mitogenic Effects of Multiple Heparin-Binding Growth Factors in Breast Cancer Cells. Cancer Res, 2001. 61(14): p. 5562-5569.

104. Barbareschi, M., et al., High Syndecan-1 Expression in Breast Carcinoma Is Related to an Aggressive Phenotype and to Poorer Prognosis. Cancer, 2003. 98(3): p. 474-483.

105. Burbach, B.J., et al., Syndecan-1 Accumulates in Lysosomes of Poorly Differentiated Breast Carcinoma Cells. Matrix Biol, 2003. 22(2): p. 163-177.

106. Burbach, B.J., Y. Ji, and A.C. Rapraeger, Syndecan-1 Ectodomain Regulates Matrix-Dependent Signaling in Human Breast Carcinoma Cells. Exp Cell Res, 2004. 300(1): p. 234-247.

107. Ranki, T., et al., A Heparan Sulfate-Targeted Conditionally Replicative Adenovirus, Ad5.Pk7-Delta24, for the Treatment of Advanced Breast Cancer. Gene Ther, 2007. 14(1): p. 58-67.

108. Wike-Hooley, J.L., J. Haveman, and H.S. Reinhold, The Relevance of Tumour pH to the Treatment of Malignant Disease. Radiother Oncol, 1984. 2(4): p. 343-366.

109. Kumar, U., et al., Subtype-Selective Expression of the Five Somatostatin Receptors (hSstR-5) in Human Pancreatic Islet Cells: A Quantitative DoubleLabel Immunohistochemical Analysis. Diabetes, 1999. 48(1): p. 77-85.

110. Taniyama, Y., et al., Systemic Distribution of Somatostatin Receptor Subtypes in Human: An Immunohistochemical Study. Endocr J, 2005. 52(5): p. 605-611.

111. Lavi, E., et al., CXCR-4 (Fusin), a Co-Receptor for the Type 1 Human Immunodeficiency Virus (HIV-1), Is Expressed in the Human Brain in a Variety of Cell Types, Including Microglia and Neurons. Am J Pathol, 1997. 151(4): p. 1035-1042.

112. Watt, H.L. and U. Kumar, Colocalization of Somatostatin Receptors and Epidermal Growth Factor Receptors in Breast Cancer Cells. Cancer Cell Int, 2006. 6: p. 5.

113. Dolan, J.T., et al., Treatment of Metastatic Breast Cancer with Somatostatin Analogues--a Meta-Analysis. Ann Surg Oncol, 2001. 8(3): p. 227-233.

114. Schally, A.V. and A. Nagy, Chemotherapy Targeted to Cancers through Tumoral Hormone Receptors. Trends in Endocrinology and Metabolism, 2004. 15(7): p. 300-310. 
115. Bonnet, D. and J.E. Dick, Human Acute Myeloid Leukemia Is Organized as a Hierarchy That Originates from a Primitive Hematopoietic Cell. Nat Med, 1997. 3(7): p. 730-737.

116. Al-Hajj, M., et al., Prospective Identification of Tumorigenic Breast Cancer Cells. Proc Natl Acad Sci U S A, 2003. 100(7): p. 3983-3988.

117. Singh, S.K., et al., Identification of a Cancer Stem Cell in Human Brain Tumors. Cancer Res, 2003. 63(18): p. 5821-5828.

118. Galli, R., et al., Isolation and Characterization of Tumorigenic, Stem-Like Neural Precursors from Human Glioblastoma. Cancer Res, 2004. 64(19): p. 7011-7021.

119. Singh, S.K., et al., Identification of Human Brain Tumour Initiating Cells. Nature, 2004. 432(7015): p. 396-401.

120. Fillmore, C.M. and C. Kuperwasser, Human Breast Cancer Cell Lines Contain Stem-Like Cells That Self-Renew, Give Rise to Phenotypically Diverse Progeny and Survive Chemotherapy. Breast Cancer Res, 2008. 10(2): p. R25.

121. Hibbs, M.L., et al., The Cell Surface Phenotype of Mouse Neutrophils. J Immunogenet, 1985. 12(4-5): p. 247-257.

122. Gause, W.C., J.D. Mountz, and A.D. Steinberg, Subpopulations of CD4-, CD8Thymocytes. Eur J Immunol, 1987. 17(9): p. 1387-1390.

123. Ceredig, R., F. Lynch, and J. Medveczky, Phenotypic Analysis of Mouse Thymus Development. Immunol Res, 1988. 7(4): p. 265-278.

124. Lynch, F. and R. Ceredig, Ly-24 (PGP-1) Expression by Thymocytes and Peripheral T Cells. Immunol Today, 1988. 9(1): p. 7-10.

125. Murphy, T.P., D.L. Kolber, and T.L. Rothstein, Elevated Expression of PGP-1 (Ly-24) by Murine Peritoneal B Lymphocytes. Eur J Immunol, 1990. 20(5): p. 1137-1142.

126. Rougon, G., et al., The Murine Heat-Stable Antigen: A Differentiation Antigen Expressed in Both the Hematolymphoid and Neural Cell Lineages. Eur J Immunol, 1991. 21(6): p. 1397-1402.

127. Nedelec, J., et al., Isolation and Characterization of a Novel GlycosylPhosphatidylinositol-Anchored Glycoconjugate Expressed by Developing Neurons. Eur J Biochem, 1992. 203(3): p. 433-442.

128. Shirasawa, T., et al., Gene Expression of CD24 Core Peptide Molecule in Developing Brain and Developing Non-Neural Tissues. Dev Dyn, 1993. 198(1): p. 1-13.

129. Sammar, M., et al., Heat-Stable Antigen (CD24) as Ligand for Mouse P-Selectin. Int Immunol, 1994. 6(7): p. 1027-1036.

130. Johnston, G.I., et al., Structure of the Human Gene Encoding Granule Membrane Protein-140, a Member of the Selectin Family of Adhesion Receptors for Leukocytes. J Biol Chem, 1990. 265(34): p. 21381-21385.

131. Kim, F.J., et al., HTLV-1 and-2 Envelope SU Subdomains and Critical Determinants in Receptor Binding. Retrovirology, 2004. 1: p. 41.

132. Kavanaugh, M.P., et al., Cell-Surface Receptors for Gibbon Ape Leukemia Virus and Amphotropic Murine Retrovirus Are Inducible Sodium-Dependent Phosphate Symporters. Proc Natl Acad Sci U S A, 1994. 91(15): p. 7071-7075. 
133. Zolotukhin, S., et al., Recombinant Adeno-Associated Virus Purification Using Novel Methods Improves Infectious Titer and Yield. Gene Ther, 1999. 6(6): p. 973-985.

134. Segura MM, K.A., Trudel P, Garnier A., A Novel Purification Strategy for Retrovirus Gene Therapy Vectors Using Heparin Affinity Chromatography. Biotechnol Bioeng. , 2005. 90(4): p. 391-404.

135. de las Mercedes Segura, M., et al., Exploiting Heparin-Binding Properties of MoMLV-Based Retroviral Vectors for Affinity Chromatography. Journal of Chromatography B: Analytical Technologies in the Biomedical and Life Sciences, 2007. 846(1-2): p. 124-131.

136. Lavillette, D., et al., Activation of a Cell Entry Pathway Common to Type C Mammalian Retroviruses by Soluble Envelope Fragments. J Virol, 2000. 74(1): p. 295-304. 


\section{Appendix A. Supplemental Plasmids}

\section{GV-1 through 5. Sst/RBS Stabilization}

Rationale. These constructs are based on the Sst/RBS construct described in Chapter 1. Sst/RBS infected at levels only half as potent as wild type MoMLV. Possible explanations for this are a defect in either fusion or envelope stability. Previous studies in the Albritton lab have shown that the point mutations Q227R and D243Y can rescue mutants defective in fusion and stability. Additionally, an R95D has been shown to improve upon stability. The mechanism by which these point mutations restore fusion and stability is unknown.

Method. In order to keep with the lab's preference of producing the MoMLV using the three-plasmid system (packaging sequence and lac $Z$ gene within the H1-BAG cell genome, gag and pol genes on one plasmid, env gene on another plasmid) to reduce the probability of a recombination event which would produce replication competent virions, all constructs were made using plasmid 3245 as their backbone with each insert bringing in not only the point mutations, but the Sst/RBS envelope sequence as well.

To create the GV-1 and 2 plasmids, plasmid 3245 was digested with PmlI and BspEI as were plasmids FL-28 (Sst/RBS) and MS-10 (Sst/RBS + R95D). The $\sim 800$ bp bands from FL-28 and MS-10 and the $\sim 6600 \mathrm{bp}$ band from the 3245 plasmid were purified and ligated together.

To create the GV-3, 4, and 5 plasmids, the GV-2, 838 (H8R + Q225R + D243Y), 2027 (H8R + Q227R), and 2059 (D243Y) plasmids were digested with BspEI and EcoRI. The $\sim 1300$ bp bands from plasmids 838, 2027, and 2059 and the $\sim 6100$ bp band from plasmid GV-2 were purified and ligated together. All plasmids were verified by DNA sequencing. Construction notes and plasmid maps may be found in Appendix C.

\section{GV-6. Plasmid 3240 Envelope Gene Reduction.}

Rationale. While verifying the sequence of every available tube labeled plasmid 3420 in an effort to identify mislabeled DNA, we determined that the current 3240 plasmid contained $736 \mathrm{bp}$ ( 245 amino acids) of the envelope protein coding sequence. Since the RBD is contained in the first $688 \mathrm{bp}$ (229 amino acids), there exists the potential for any virus produced using this plasmid to be contaminated with free RBD. Previous studies have shown that free RBD has the ability to enhance infection at low levels and interfere with infections at moderate to high levels and that it can also rescue virus rendered noninfectious due to fusion defects [136]. The removal of this contaminant in virus performance was absolutely necessary, especially where targeted studies were concerned. 
Another issue arose in the form of increased probability of a homologous recombination event between this structural plasmid and the provirus located within the pBAG plasmid in the H1-BAG cell genome.

Method. A 3240 plasmid (JF 3240) was digested with HpaI. The ends were filled using Klenow and the resulting blunt ends were ligated. Three correct clones were identified via the loss of the HpaI site and verified by DNA sequencing. Construction notes and a plasmid map may be found in Appendix C.

\section{GVTS45 and GV752. Removal of the MluI Site in the pcDNA3_delNeo Plasmid CMV Promoter Sequence}

Rationale. As the HBS mutants were being made and I was entering more data into the Vector NTI TM program, I realized that there was an MluI site in the pcDNA3 del Neo backbone of all of the viral expression plasmids. This became an issue when it was necessary to digest the 752_del RBS plasmid with MluI and insert the PCR amplified and mutated HBS sequences with the del RBS (and the MluI site contained therein) attached to their 5' end into it. Removal of this MluI site was also necessary for the del RBS design to truly be the "plug and play" vector it was designed to be.

Method. Plasmids TS45 and 752 were digested with MluI, the ends were Klenow filled and the resulting blunt ends were ligated. Upon screening, only the TS45 clones showed a loss of the MluI site. One clone was verified by DNA sequencing and named GVTS45. Irregular filling caused the loss of a " $g$ " at the ligation junction when compared to the expected sequence of "acgcgcgcgt". The verified sequence reads "acgccgcgt".

The SnaBI/EcoRI fragment of plasmid GVTS45 was PCR amplified using oligonucleotide primers pCMVas and M-17+2. This PCR product and the 752 plasmid were digested with SnaBI and EcoRI. Mini-prepped plasmids were screened for loss of the MluI site. Three correct clones were confirmed by DNA sequencing and purified from individual $E$. coli Top $10 \mathrm{~F}^{\prime}$ colonies. This prep of GV752 plasmid DNA was used to produce virus using the two-plasmid system. The titer of this GV752 MoMLV was compared to that of wild type MoMLV. Construction notes and plasmid maps may be found in Appendix C.

Results. GV752 MoMLV was more infectious than the wild type MoMLV as illustrated in Figure A-1. While it is possible and even probable that the removal of this MluI site created an enhancer sequence within the CMV promoter (the MluI site was located at the 5 ' end of the promoter), the reason for increased virus production using GV752 MoMLV was not determined. 
A.

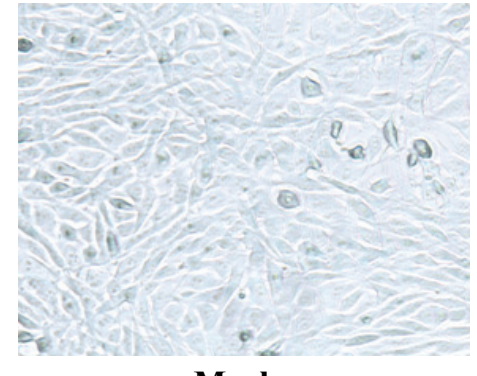

Mock

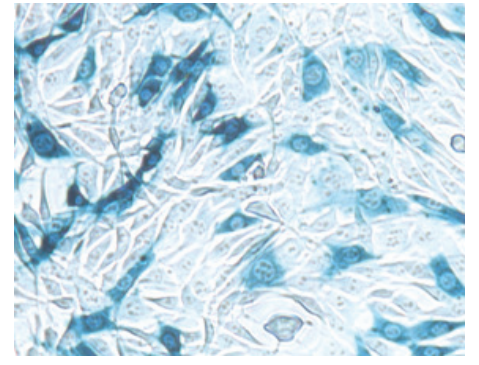

752

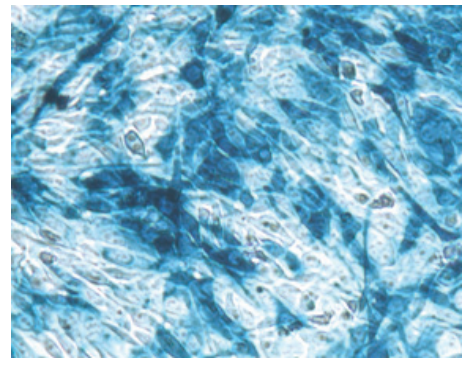

GV752

B.

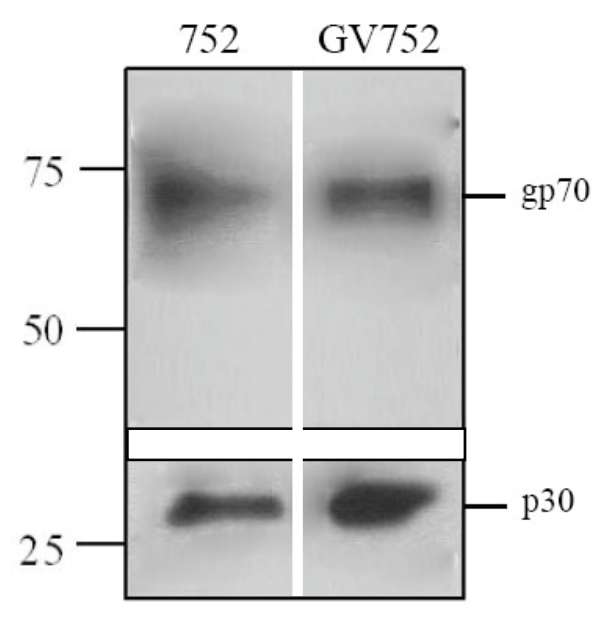

Figure A-1. 752 vs. GV752. (A) Micrograph image of Mock, 752, and GV752 virus transduction of NIH $3 \mathrm{~T} 3$ cells and (B) Western blot analysis of viral pellets. 


\section{Appendix B. Fusion Assay}

\section{Rationale}

Following up on the Sst/RBS design, F. Li and B. Ryu worked together to create plasmid 752-based constructs with other short ligands, similar in size and differing in disulfide bond configuration compared to the natural RBS replacing the WT MoMLV RBS sequence in an attempt to answer the following questions:

1. Is size the only restriction? MoMLV RBS $=14$ amino acids (aa), Sst $=14$ aa, SDF-1a $=61,63, \& 68$ aa.

2. Is structure the only restriction? MoMLV RBS $=$ two disulfide bonds, $\mathrm{Sst}=1$ disulfide bond, SDF-1a $=2$ disulfide bonds and a very different secondary structure from that of MoMLV RBS.

3. Is binding site location a restriction? MoMLV $=\mathrm{D} 84$ (on C-terminal side of RBS), Sst $=$ aa's looped out by disulfide bonds, SDF-1a $=\mathrm{N}$-terminal and underside of antiparallel $\beta$-sheets.

4. Are size, structure, and binding site location all restrictive?

5. Are only structure and binding site location restrictive?

6. Are only size and binding site location restrictive?

7. Are only structure and size restrictive?

Through their notebooks and miscellaneous planning sheets, I ascertained that plasmids with gastrin, galanin, oxytocin, substance $P$, endothelin, neurotensin, bombesin (GRP), two versions of bombesin flanked with cystines, RGD-14, and RGD-14 flanked by cystines replacing the RBS were constructed using PCR mutagenesis on the pUC-Env plasmid and subcloned into plasmid 752 by F. Li and B. Ryu. Virus production and analysis was inconclusive based on the data we could locate.

In an effort to create a high throughput screening assay for chimeric envelope/receptor interactions, we employed an alpha complementation assay that had been modified for use in a eukaryotic system. Briefly, the N-terminal portion of the $\beta$-gal enzyme (alpha) is expressed in one cell while a version with deletions in the alpha region (omega) is expressed in another. When the cells fuse, the alpha protein rescues the ability of the omega protein to form the tetrameric structure necessary for $\beta$-gal activity. Moosman \& Rusconi developed a mammalian version which was adapted by N. Landau for use in protein/protein interactions and further expanded as a fusion analysis tool to study the interaction between a CXCR-4 specific HIV-1 glycoprotein and its receptor [97]. This assay would allow for screening of chimeric RBS envelopes at a lower biosafety level than would be necessary when the potential for producing replication competent human-directed virus exists. RCR assays have since been performed on virus produced using the two-plasmid system and the probability of replication competent virus production has been shown to be of negligible concern. An additional benefit to this assay is the ability to use smaller amounts of lower purity DNA than is required for virus production. 
To modify this assay for use in screening chimeric envelope proteins, we needed an envelope protein that would be active in the context of a cell membrane. The R-peptide is responsible for maintaining a non-fusogenic envelope conformation until budding has occurred at which time the R-peptide is cleaved to allow fusion of the virion with the cell membrane. R-less envelope proteins are truncated at the R-peptide cleavage point $\left(\mathrm{V}_{616}\right)$ thus allowing fusion as soon as the envelope protein is expressed on the host cell surface.

\section{Method}

After determining which of these ligands had receptors that were expressed on the MDA-MB-231 breast cancer cell line, I amplified the BstEII/BamHI fragments from the oxytocin, substance $P$, endothelin, neurotensin, bombesin (GRP), 2 versions of bombesin flanked with cystines, RGD-14 flanked by cystines, and RGD-14 RBS chimeras using PCR and the env-10 and M-6 oligonucleotides, digested the $\sim 1300$ bp products with $B s t E I I$ and BamHI, and purified the $\sim 600$ bp band. I then digested the TS45-R-less plasmids with BstEII and BamHI and purified the $\sim 6000 \mathrm{bp}$ band and ligated the two fragments together to form Ligand X/RBS-R-less plasmids.

The fusion assay was performed as follows: Transfect 293 cells with the alpha and Rless envelope constructs. Transfect MDA-MB-231 cells with the omega plasmid. Combine the two cell lines as desired at a 1:1 ratio and seed 24-well plates. Forty-eight hours later, fix and stain the 24-well plates with X-gal and count the number of syncytia expressing $\beta$-gal activity.

Breast cancer cell lines are notoriously difficult to transfect. To determine the best method, I tried three different reagents in many different combinations. Trans-IT (Mirus) in DMEM was the most effective. See Table B-1 for a complete list of conditions and results.

\section{Results}

Unfortunately, low levels of fusion are nearly impossible to detect accurately using this assay (Figure B-1). Even Sst/RBS Env partnered with SstR5, which infects in the $10^{5}$ range, failed to form detectable syncytia. There was also a low level of individual cells expressing $\beta$-gal activity. Additionally, the potential for false positives was indicated in the del RBS/EcoR combination. Three syncytia were observed (in three wells with an average of one per well), but the del RBS virus did not infect NIH 3T3 cells at all (see Chapter 4). 
Table B-1. Transfection Optimization.

\begin{tabular}{|c|c|c|c|c|c|c|c|c|c|c|c|c|c|}
\hline \multirow[b]{2}{*}{$\begin{array}{c}\text { Date of } \\
\text { Analysis }\end{array}$} & \multirow[b]{2}{*}{ Cell Line } & \multirow[b]{2}{*}{$\begin{array}{c}\text { Ratio } \\
\text { (Lipid:DNA) }\end{array}$} & \multirow[b]{2}{*}{$\underset{\mathbf{p G L}}{\mathbf{u g}}$} & \multirow[b]{2}{*}{ Reagent } & \multirow[b]{2}{*}{$\begin{array}{c}\text { \% Confluent at } \\
\text { Transfection }\end{array}$} & \multicolumn{3}{|c|}{ Field 1} & \multicolumn{3}{|c|}{ Field 2} & \multirow[b]{2}{*}{ Average $\%$} & \multirow[b]{2}{*}{ Notes: } \\
\hline & & & & & & $\begin{array}{l}\text { \# of } \\
\text { cells }\end{array}$ & $\begin{array}{c}\text { \# of cells } \\
\text { expressing } \\
\text { GFP }\end{array}$ & $\begin{array}{l}\text { Transfection } \\
\text { Efficiency } \\
\text { (\%) }\end{array}$ & $\begin{array}{l}\text { \# of } \\
\text { cells }\end{array}$ & $\begin{array}{c}\text { \# of cells } \\
\text { expressing } \\
\text { GFP }\end{array}$ & $\begin{array}{c}\text { Transfection } \\
\text { Efficiency } \\
(\%)\end{array}$ & & \\
\hline $2 / 15 / 2007$ & $\begin{array}{l}\text { MDA-MB- } \\
231\end{array}$ & $3: 1$ & 5 & FuGene6 & $60 \%$ & 40 & 3 & $7.5 \%$ & 30 & 4 & $13.3 \%$ & $10.4 \%$ & $\begin{array}{l}24 \text { hours } \\
\text { post-TF }\end{array}$ \\
\hline $2 / 15 / 2007$ & $\begin{array}{l}\text { MDA-MB- } \\
231\end{array}$ & $3: 1$ & 10 & FuGene6 & $60 \%$ & 43 & 5 & $11.6 \%$ & 32 & 1 & $3.1 \%$ & $7.4 \%$ & $\begin{array}{l}24 \text { hours } \\
\text { post-TF }\end{array}$ \\
\hline $2 / 15 / 2007$ & 293 & $3: 1$ & 5 & FuGene6 & $60 \%$ & 103 & 23 & $22.3 \%$ & 109 & 26 & $23.9 \%$ & $23.1 \%$ & $\begin{array}{l}24 \text { hours } \\
\text { post-TF }\end{array}$ \\
\hline $2 / 15 / 2007$ & 293 & $3: 1$ & 10 & FuGene6 & $60 \%$ & 102 & 45 & $44.1 \%$ & 78 & 29 & $37.2 \%$ & $40.6 \%$ & $\begin{array}{l}24 \text { hours } \\
\text { post-TF }\end{array}$ \\
\hline $2 / 15 / 2007$ & 293 & $6: 1$ & 5 & Lipofectamine & $60 \%$ & 45 & 28 & $62.2 \%$ & 58 & 35 & $60.3 \%$ & $61.3 \%$ & $\begin{array}{l}24 \text { hours } \\
\text { post-TF }\end{array}$ \\
\hline $2 / 18 / 2007$ & $\begin{array}{l}\text { MDA-MB- } \\
231\end{array}$ & $6: 1$ & 5 & Lipofectamine & $60 \%$ & 20 & 7 & $35.0 \%$ & 18 & 5 & $27.8 \%$ & $31.4 \%$ & $\begin{array}{l}24 \text { hours } \\
\text { post-TF, no } \\
\text { rinse before } \\
\text { adding } \\
\text { complex, } \\
\text { fresh media } \\
\text { after } 4 \text { hours }\end{array}$ \\
\hline $2 / 19 / 2007$ & $\begin{array}{l}\text { MDA-MB- } \\
231\end{array}$ & $6: 1$ & 5 & Lipofectamine & $60 \%$ & 19 & 9 & $47.4 \%$ & 26 & 8 & $30.8 \%$ & $39.1 \%$ & $\begin{array}{l}48 \text { hours } \\
\text { post-TF, no } \\
\text { rinse before } \\
\text { adding } \\
\text { complex, } \\
\text { fresh media } \\
\text { after } 4 \text { hours }\end{array}$ \\
\hline $2 / 19 / 2007$ & $\begin{array}{l}\text { MDA-MB- } \\
231\end{array}$ & $6: 1$ & 5 & Lipofectamine & $60 \%$ & 28 & 8 & $28.6 \%$ & 17 & 9 & $52.9 \%$ & $40.8 \%$ & $\begin{array}{l}24 \text { hours } \\
\text { post-TF, split } \\
2 x \text { before TF, } \\
\text { no rinse } \\
\text { before adding } \\
\text { complex, } \\
\text { fresh media } \\
\text { after } 4 \text { hours }\end{array}$ \\
\hline
\end{tabular}


Table B-1 (continued).

\begin{tabular}{|c|c|c|c|c|c|c|c|c|c|c|c|c|c|}
\hline \multirow[b]{2}{*}{$\begin{array}{c}\text { Date of } \\
\text { Analysis }\end{array}$} & \multirow[b]{2}{*}{ Cell Line } & \multirow[b]{2}{*}{$\begin{array}{c}\text { Ratio } \\
\text { (Lipid:DNA) }\end{array}$} & \multirow[b]{2}{*}{$\underset{\mathbf{p G L}}{\mathbf{u g}}$} & \multirow[b]{2}{*}{ Reagent } & \multirow[b]{2}{*}{$\begin{array}{l}\text { \% Confluent at } \\
\text { Transfection }\end{array}$} & \multicolumn{3}{|c|}{ Field 1} & \multicolumn{3}{|c|}{ Field 2} & \multirow[b]{2}{*}{ Average \% } & \multirow[b]{2}{*}{ Notes: } \\
\hline & & & & & & $\begin{array}{l}\# \text { of } \\
\text { cells }\end{array}$ & $\begin{array}{l}\text { \# of cells } \\
\text { expressing } \\
\text { GFP }\end{array}$ & $\begin{array}{c}\text { Transfection } \\
\text { Efficiency } \\
\text { (\%) }\end{array}$ & $\begin{array}{l}\text { \# of } \\
\text { cells }\end{array}$ & $\begin{array}{c}\text { \# of cells } \\
\text { expressing } \\
\text { GFP }\end{array}$ & $\begin{array}{c}\text { Transfection } \\
\text { Efficiency } \\
(\%)\end{array}$ & & \\
\hline 2/20/2007 & $\begin{array}{c}\text { MDA-MB- } \\
231\end{array}$ & $6: 1$ & 5 & Lipofectamine & $60 \%$ & 24 & 5 & $20.8 \%$ & 25 & 6 & $24.0 \%$ & $22.4 \%$ & $\begin{array}{c}48 \text { hours } \\
\text { post-TF, split } \\
2 \mathrm{x} \text { before TF, } \\
\text { no rinse } \\
\text { before adding } \\
\text { complex, } \\
\text { fresh media } \\
\text { after } 4 \text { hours }\end{array}$ \\
\hline 2/18/2007 & 293 & $6: 1$ & 5 & Lipofectamine & $60 \%$ & 65 & 47 & $72.3 \%$ & 37 & 30 & $81.1 \%$ & $76.7 \%$ & $\begin{array}{l}24 \text { hours } \\
\text { post-TF, no } \\
\text { rinse before } \\
\text { adding } \\
\text { complex, } \\
\text { fresh media } \\
\text { after } 4 \text { hours }\end{array}$ \\
\hline 2/19/2007 & 293 & $6: 1$ & 5 & Lipofectamine & $60 \%$ & 135 & 63 & $46.7 \%$ & 103 & 53 & $51.5 \%$ & $49.1 \%$ & $\begin{array}{l}48 \text { hours } \\
\text { post-TF, no } \\
\text { rinse before } \\
\text { adding } \\
\text { complex, } \\
\text { fresh media } \\
\text { after } 4 \text { hours }\end{array}$ \\
\hline 2/18/2007 & 293 & $6: 1$ & 5 & Lipofectamine & $60 \%$ & 95 & 50 & $52.6 \%$ & 88 & 47 & $53.4 \%$ & $53.0 \%$ & $\begin{array}{l}24 \text { hours } \\
\text { post-TF, no } \\
\text { rinse before } \\
\text { adding } \\
\text { complex, } 2 x \\
\text { media after } 4 \\
\text { hours }\end{array}$ \\
\hline 2/19/2007 & 293 & $6: 1$ & 5 & Lipofectamine & $60 \%$ & 151 & 65 & $43.0 \%$ & 94 & 42 & $44.7 \%$ & $43.9 \%$ & $\begin{array}{c}48 \text { hours } \\
\text { post-TF, no } \\
\text { rinse before } \\
\text { adding } \\
\text { complex, } 2 x \\
\text { media after } 4 \\
\text { hours }\end{array}$ \\
\hline
\end{tabular}


Tab le B-1 (continued).

\begin{tabular}{|c|c|c|c|c|c|c|c|c|c|c|c|c|c|}
\hline \multirow[b]{2}{*}{$\begin{array}{c}\text { Date of } \\
\text { Analysis }\end{array}$} & \multirow[b]{2}{*}{ Cell Line } & \multirow[b]{2}{*}{$\begin{array}{c}\text { Ratio } \\
\text { (Lipid:DNA) }\end{array}$} & \multirow[b]{2}{*}{$\begin{array}{l}\text { ug } \\
\text { pGL }\end{array}$} & \multirow[b]{2}{*}{ Reagent } & \multirow[b]{2}{*}{$\begin{array}{l}\text { \% Confluent at } \\
\text { Transfection }\end{array}$} & \multicolumn{3}{|c|}{ Field 1} & \multicolumn{3}{|c|}{ Field 2} & \multirow[b]{2}{*}{ Average $\%$} & \multirow[b]{2}{*}{ Notes: } \\
\hline & & & & & & $\begin{array}{l}\# \text { of } \\
\text { cells }\end{array}$ & $\begin{array}{l}\text { \# of cells } \\
\text { expressing } \\
\text { GFP }\end{array}$ & $\begin{array}{l}\text { Transfection } \\
\text { Efficiency } \\
\text { (\%) }\end{array}$ & $\begin{array}{l}\# \text { of } \\
\text { cells }\end{array}$ & $\begin{array}{l}\text { \# of cells } \\
\text { expressing } \\
\text { GFP }\end{array}$ & $\begin{array}{l}\text { Transfection } \\
\text { Efficiency } \\
\text { (\%) }\end{array}$ & & \\
\hline $2 / 19 / 2007$ & 293 & $6: 1$ & 5 & Lipofectamine & $60 \%$ & 102 & 62 & $60.8 \%$ & 89 & 51 & $57.3 \%$ & $59.0 \%$ & $\begin{array}{c}24 \text { hours } \\
\text { post-TF, split } \\
2 \mathrm{x} \text { before TF, } \\
\text { no rinse } \\
\text { before adding } \\
\text { complex, } \\
\text { fresh media } \\
\text { after } 4 \text { hours }\end{array}$ \\
\hline $2 / 20 / 2007$ & 293 & $6: 1$ & 5 & Lipofectamine & $60 \%$ & 109 & 67 & $61.5 \%$ & na & na & na & $61.5 \%$ & $\begin{array}{c}48 \text { hours } \\
\text { post-TF, split } \\
2 \mathrm{x} \text { before TF, } \\
\text { no rinse } \\
\text { before adding } \\
\text { complex, } \\
\text { fresh media } \\
\text { after } 4 \text { hours }\end{array}$ \\
\hline $2 / 25 / 2007$ & $\begin{array}{l}\text { MDA-MB- } \\
231\end{array}$ & $3: 1$ & 5 & FuGene6 & $60 \%$ & 33 & 7 & $21.2 \%$ & 41 & 18 & $43.9 \%$ & $32.6 \%$ & $\begin{array}{l}\text { Serum Free } \\
(2 \mathrm{x} \text { media } \\
\text { after } 4 \text { hours })\end{array}$ \\
\hline $2 / 25 / 2007$ & $\begin{array}{l}\text { MDA-MB- } \\
231\end{array}$ & $6: 1$ & 5 & FuGene6 & $60 \%$ & 51 & 9 & $17.6 \%$ & 36 & 6 & $16.7 \%$ & $17.2 \%$ & $\begin{array}{l}\text { Serum Free } \\
(2 \mathrm{x} \text { media } \\
\text { after } 4 \text { hours })\end{array}$ \\
\hline $2 / 25 / 2007$ & $\begin{array}{c}\text { MDA-MB- } \\
231\end{array}$ & $3: 1$ & 5 & FuGene6 & $60 \%$ & 40 & 7 & $17.5 \%$ & & & & $17.5 \%$ & $\begin{array}{l}\text { Regular } \\
\text { Media }\end{array}$ \\
\hline $2 / 25 / 2007$ & $\begin{array}{l}\text { MDA-MB- } \\
231\end{array}$ & $6: 1$ & 5 & FuGene6 & $60 \%$ & 29 & 5 & $17.2 \%$ & 39 & 6 & $15.4 \%$ & $16.3 \%$ & $\begin{array}{l}\text { Regular } \\
\text { Media }\end{array}$ \\
\hline $2 / 25 / 2007$ & $\begin{array}{l}\text { MDA-MB- } \\
231\end{array}$ & $6: 1$ & 5 & TransIT & $60 \%$ & 34 & 10 & $29.4 \%$ & 27 & 7 & $25.9 \%$ & $27.7 \%$ & $\begin{array}{l}\text { Serum Free } \\
(2 x \text { media } \\
\text { after } 4 \text { hours })\end{array}$ \\
\hline $2 / 25 / 2007$ & $\begin{array}{l}\text { MDA-MB- } \\
231\end{array}$ & $3: 1$ & 5 & TransIT & $60 \%$ & 29 & 6 & $20.7 \%$ & 28 & 6 & $21.4 \%$ & $21.1 \%$ & $\begin{array}{l}\text { Regular } \\
\text { Media }\end{array}$ \\
\hline $2 / 25 / 2007$ & $\begin{array}{c}\text { MDA-MB- } \\
231\end{array}$ & $6: 1$ & 5 & TransIT & $60 \%$ & 39 & 10 & $25.6 \%$ & 25 & 10 & $40.0 \%$ & $32.8 \%$ & $\begin{array}{l}\text { Regular } \\
\text { Media }\end{array}$ \\
\hline
\end{tabular}


Table B-1 (continued).

\begin{tabular}{|c|c|c|c|c|c|c|c|c|c|c|c|c|c|}
\hline \multirow[b]{2}{*}{$\begin{array}{c}\text { Date of } \\
\text { Analysis }\end{array}$} & \multirow[b]{2}{*}{ Cell Line } & \multirow[b]{2}{*}{$\begin{array}{c}\text { Ratio } \\
\text { (Lipid:DNA) }\end{array}$} & \multirow[b]{2}{*}{$\underset{\text { pGL }}{\text { ug }}$} & \multirow[b]{2}{*}{ Reagent } & \multirow[b]{2}{*}{$\begin{array}{l}\text { \% Confluent at } \\
\text { Transfection }\end{array}$} & \multicolumn{3}{|c|}{ Field 1} & \multicolumn{3}{|c|}{ Field 2} & \multirow[b]{2}{*}{ Average\% } & \multirow[b]{2}{*}{ Notes: } \\
\hline & & & & & & $\begin{array}{l}\# \text { of } \\
\text { cells }\end{array}$ & $\begin{array}{l}\text { \# of cells } \\
\text { expressing } \\
\text { GFP }\end{array}$ & $\begin{array}{l}\text { Transfection } \\
\text { Efficiency } \\
(\%)\end{array}$ & $\begin{array}{l}\# \text { of } \\
\text { cells }\end{array}$ & $\begin{array}{l}\text { \# of cells } \\
\text { expressing } \\
\text { GFP }\end{array}$ & $\begin{array}{l}\text { Transfection } \\
\text { Efficiency } \\
(\%)\end{array}$ & & \\
\hline $2 / 25 / 2007$ & $\begin{array}{l}\text { MDA-MB- } \\
231\end{array}$ & $6: 1$ & 5 & Lipofectamine & $60 \%$ & 21 & 7 & $33.3 \%$ & 18 & 4 & $22.2 \%$ & $27.8 \%$ & $\begin{array}{l}\text { Serum Free } \\
\text { (fresh media } \\
\text { after } 4 \text { hours) }\end{array}$ \\
\hline $2 / 25 / 2007$ & $\begin{array}{l}\text { MDA-MB- } \\
231\end{array}$ & $6: 1$ & 5 & Lipofectamine & $60 \%$ & 28 & 1 & $3.6 \%$ & 27 & 0 & $0.0 \%$ & $1.8 \%$ & $\begin{array}{l}\text { Regular } \\
\text { Media }\end{array}$ \\
\hline $2 / 28 / 2007$ & $\begin{array}{l}\text { MDA-MB- } \\
231\end{array}$ & $3: 1$ & 5 & Lipofectamine & $70 \%$ & 33 & 3 & $9.1 \%$ & 30 & 3 & $10.0 \%$ & $9.5 \%$ & $\begin{array}{l}\text { Fresh media } \\
\text { after } 4 \text { hours }\end{array}$ \\
\hline 2/28/2007 & $\begin{array}{l}\text { MDA-MB- } \\
231\end{array}$ & $3: 1$ & 5 & FuGene6 & $65 \%$ & 42 & 7 & $16.7 \%$ & 30 & 7 & $23.3 \%$ & $20.0 \%$ & $\begin{array}{l}\text { Regular } \\
\text { Media }\end{array}$ \\
\hline $2 / 28 / 2007$ & $\begin{array}{l}\text { MDA-MB- } \\
231\end{array}$ & $3: 1$ & 5 & FuGene6 & $55 \%$ & 19 & 4 & $21.1 \%$ & 28 & 4 & $14.3 \%$ & $17.7 \%$ & $\begin{array}{l}\text { Regular } \\
\text { Media }\end{array}$ \\
\hline $2 / 28 / 2007$ & 293 & $3: 1$ & 5 & FuGene6 & $80 \%$ & 121 & 48 & $39.7 \%$ & 135 & 53 & $39.3 \%$ & $39.5 \%$ & $\begin{array}{l}\text { Regular } \\
\text { Media }\end{array}$ \\
\hline $3 / 1 / 2007$ & $\begin{array}{l}\text { MDA-MB- } \\
231\end{array}$ & $3: 1$ & 5 & Lipofectamine & $55 \%$ & 24 & 2 & $8.3 \%$ & 20 & 3 & $15.0 \%$ & $11.7 \%$ & $\begin{array}{l}\text { Fresh media } \\
\text { after } 4 \text { hours }\end{array}$ \\
\hline $3 / 1 / 2007$ & 293 & $3: 1$ & 5 & Lipofectamine & $55 \%$ & 63 & 10 & $15.9 \%$ & 47 & 5 & $10.6 \%$ & $13.3 \%$ & $\begin{array}{l}\text { Fresh media } \\
\text { after } 4 \text { hours }\end{array}$ \\
\hline $3 / 1 / 2007$ & 293 & $3: 1$ & 5 & FuGene6 & $55 \%$ & 66 & 32 & $48.5 \%$ & 69 & 24 & $34.8 \%$ & $41.6 \%$ & $\begin{array}{l}\text { Regular } \\
\text { Media }\end{array}$ \\
\hline $3 / 8 / 2007^{1}$ & $\begin{array}{c}\text { MDA-MB- } \\
231\end{array}$ & $6: 1$ & 5 & TransIT & $65 \%$ & 28 & 11 & $39.3 \%$ & 27 & 8 & $29.6 \%$ & $34.5 \%$ & $\begin{array}{l}\text { Regular } \\
\text { Media }\end{array}$ \\
\hline $3 / 8 / 2007$ & $\begin{array}{l}\text { MDA-MB- } \\
231\end{array}$ & $6: 1$ & 5 & Lipofectamine & $65 \%$ & 9 & 1 & $11.1 \%$ & 5 & 1 & $20.0 \%$ & $15.6 \%$ & $\begin{array}{l}\text { Fresh media } \\
\text { after } 4 \text { hours }\end{array}$ \\
\hline $3 / 8 / 2007$ & $\begin{array}{l}\text { MDA-MB- } \\
231\end{array}$ & $3: 1$ & 5 & FuGene6 & $65 \%$ & 33 & 9 & $27.3 \%$ & 27 & 8 & $29.6 \%$ & $28.5 \%$ & $\begin{array}{l}\text { Fresh media } \\
\text { after } 4 \text { hours }\end{array}$ \\
\hline $3 / 8 / 2007$ & 293 & $6: 1$ & 5 & TransIT & $65 \%$ & 94 & 58 & $61.7 \%$ & 96 & 69 & $71.9 \%$ & $66.8 \%$ & $\begin{array}{l}\text { Regular } \\
\text { Media }\end{array}$ \\
\hline $3 / 8 / 2007$ & 293 & $6: 1$ & 5 & Lipofectamine & $65 \%$ & 95 & 49 & $51.6 \%$ & 94 & 63 & $67.0 \%$ & $59.3 \%$ & $\begin{array}{l}\text { Fresh media } \\
\text { after } 4 \text { hours }\end{array}$ \\
\hline $3 / 8 / 2007$ & 293 & $3: 1$ & 5 & FuGene6 & $65 \%$ & 134 & 56 & $41.8 \%$ & 133 & 55 & $41.4 \%$ & $41.6 \%$ & $\begin{array}{l}\text { Fresh media } \\
\text { after } 4 \text { hours }\end{array}$ \\
\hline $3 / 9 / 2007$ & $\begin{array}{l}\text { MDA-MB- } \\
231\end{array}$ & $6: 1$ & 5 & TransIT & $65 \%$ & 34 & 8 & $23.5 \%$ & 33 & 8 & $24.2 \%$ & $23.9 \%$ & $\begin{array}{c}\text { Split 2x } \\
\text { before TF, } \\
\text { Regular } \\
\text { media }\end{array}$ \\
\hline
\end{tabular}


Table B-1 (continued).

\begin{tabular}{|c|c|c|c|c|c|c|c|c|c|c|c|c|c|}
\hline \multirow[b]{2}{*}{$\begin{array}{l}\text { Date of } \\
\text { Analysis }\end{array}$} & \multirow[b]{2}{*}{ Cell Line } & \multirow[b]{2}{*}{$\begin{array}{c}\text { Ratio } \\
\text { (Lipid:DNA) }\end{array}$} & \multirow[b]{2}{*}{$\underset{\text { pGL }}{\text { ug }}$} & \multirow[b]{2}{*}{ Reagent } & \multirow[b]{2}{*}{$\begin{array}{l}\text { \% Confluent at } \\
\text { Transfection }\end{array}$} & \multicolumn{3}{|c|}{ Field 1} & \multicolumn{3}{|c|}{ Field 2} & \multirow[b]{2}{*}{ Average $\%$} & \multirow[b]{2}{*}{ Notes: } \\
\hline & & & & & & $\begin{array}{l}\text { \# of } \\
\text { cells }\end{array}$ & $\begin{array}{c}\text { \# of cells } \\
\text { expressing } \\
\text { GFP }\end{array}$ & $\begin{array}{c}\text { Transfection } \\
\text { Efficiency } \\
(\%)\end{array}$ & $\begin{array}{l}\text { \# of } \\
\text { cells }\end{array}$ & $\begin{array}{c}\text { \# of cells } \\
\text { expressing } \\
\text { GFP }\end{array}$ & $\begin{array}{l}\text { Transfection } \\
\text { Efficiency } \\
\text { (\%) }\end{array}$ & & \\
\hline $3 / 9 / 2007$ & $\begin{array}{c}\text { MDA-MB- } \\
231\end{array}$ & $6: 1$ & 5 & Lipofectamine & $65 \%$ & 12 & 2 & $16.7 \%$ & 14 & 2 & $14.3 \%$ & $15.5 \%$ & $\begin{array}{c}\text { Split } 2 \mathrm{x} \\
\text { before TF, } \\
\text { Fresh media } \\
\text { after } 4 \text { hours }\end{array}$ \\
\hline $3 / 9 / 2007$ & $\begin{array}{c}\text { MDA-MB- } \\
231\end{array}$ & $3: 1$ & 5 & FuGene6 & $65 \%$ & 40 & 9 & $22.5 \%$ & 28 & 9 & $32.1 \%$ & $27.3 \%$ & $\begin{array}{c}\text { Split } 2 \mathrm{x} \\
\text { before TF, } \\
\text { Fresh media } \\
\text { after } 4 \text { hours }\end{array}$ \\
\hline $3 / 9 / 2007$ & 293 & $6: 1$ & 5 & TransIT & $65 \%$ & 100 & 54 & $54.0 \%$ & 111 & 57 & $51.4 \%$ & $52.7 \%$ & $\begin{array}{c}\text { Split } 2 \mathrm{x} \\
\text { before TF, } \\
\text { Regular } \\
\text { media }\end{array}$ \\
\hline $3 / 9 / 2007$ & 293 & $6: 1$ & 5 & Lipofectamine & $65 \%$ & 64 & 35 & $54.7 \%$ & 79 & 46 & $58.2 \%$ & $56.5 \%$ & $\begin{array}{c}\text { Split } 2 \mathrm{x} \\
\text { before TF, } \\
\text { Fresh media } \\
\text { after } 4 \text { hours }\end{array}$ \\
\hline $3 / 9 / 2007$ & 293 & $3: 1$ & 5 & FuGene6 & $65 \%$ & 112 & 52 & $46.4 \%$ & 122 & 51 & $41.8 \%$ & $44.1 \%$ & $\begin{array}{c}\text { Split } 2 \mathrm{x} \\
\text { before } \mathrm{TF} \\
\text { Fresh media } \\
\text { after } 4 \text { hours }\end{array}$ \\
\hline
\end{tabular}

${ }^{1}$ The top performing conditions and reagent for each cell type are shaded gray. 
A.

Mock

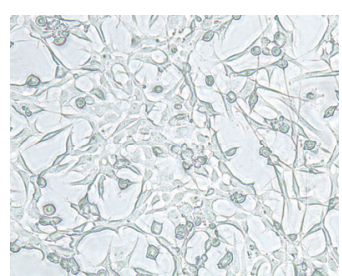

WT/EcoR

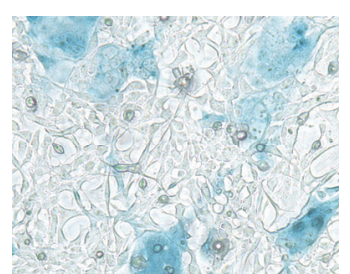

SstRBS/SstR5

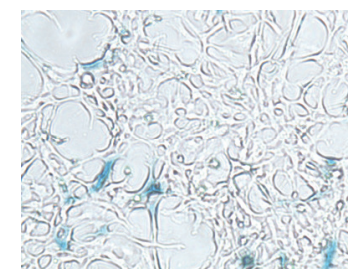

WT/SstR5
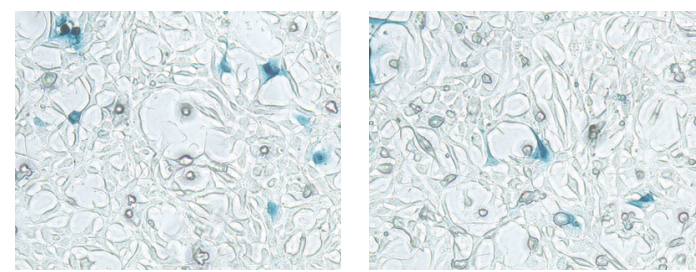

B.

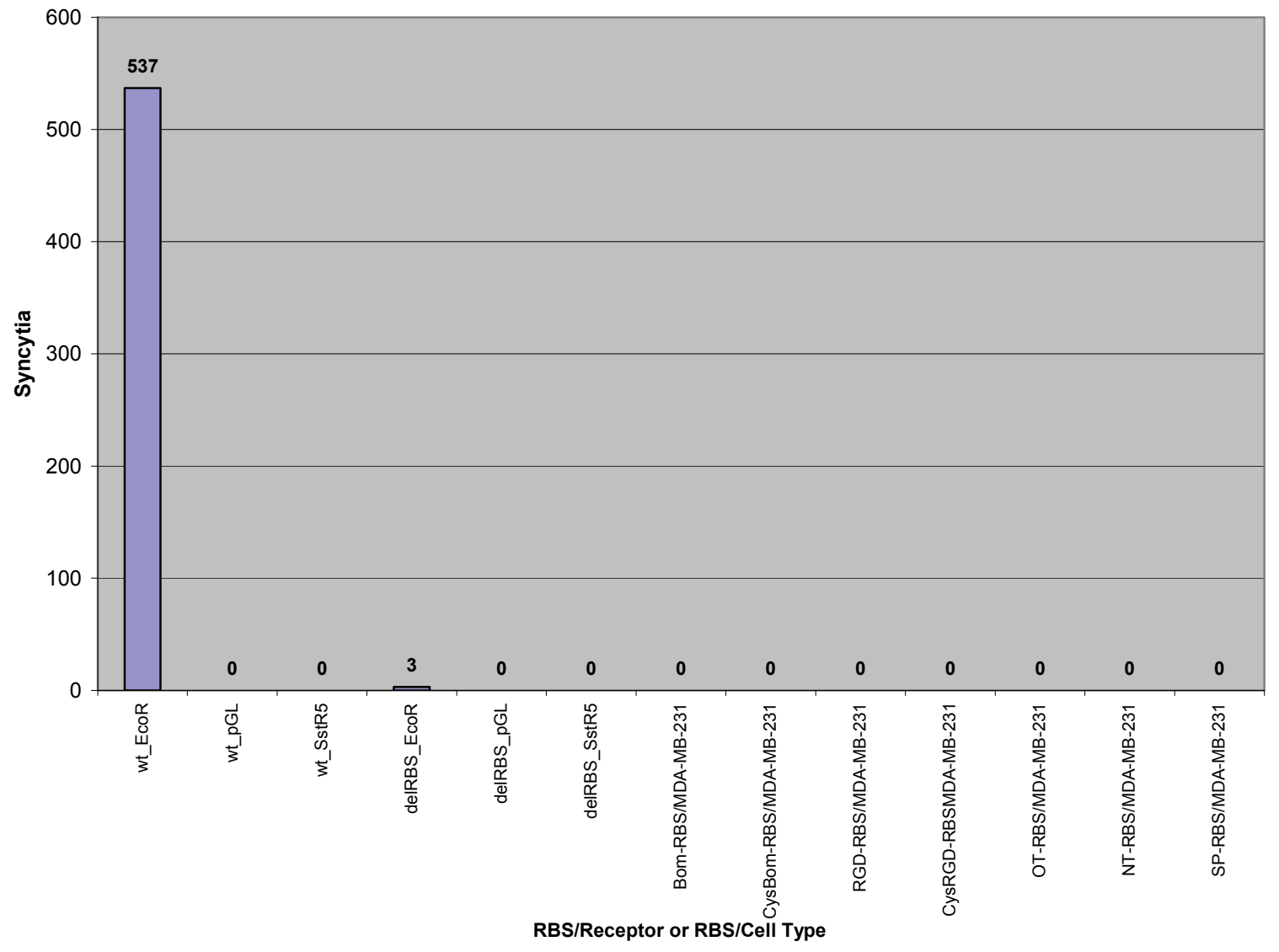

Figure B-1. Fusion Assay Results. (A) Micrographs of fusion assay controls. Mock is alpha/293 + omega/MDA-MB-231. (B) Graph depicting the number of syncytia formed during fusion assay. 


\section{Appendix C. Plasmids}

Table C-1. Plasmids Constructed and Used.

\begin{tabular}{|c|c|c|c|c|c|c|}
\hline Category & Construct Name & Backbone & Insert & $\begin{array}{c}\text { Constructed } \\
\text { By }\end{array}$ & Map & Notes \\
\hline \multicolumn{7}{|l|}{$\begin{array}{l}\text { General Use } \\
\text { Plasmids }\end{array}$} \\
\hline & pUC18 & na & na & purchaced & $\mathrm{C}-1$ & \\
\hline & pcDNA3 & na & na & purchaced & $\mathrm{C}-2$ & \\
\hline & pcDNA3_delNeo & na & na & na & $\mathrm{C}-3$ & del 2093-3199 \\
\hline & $\operatorname{EcoR}(1475)$ & pcDNA3 (BamHI, EcoRI) & $\begin{array}{l}\text { EcoR cDNA (BamHI, } \\
\text { EcoRI) }\end{array}$ & LA & NA & \\
\hline & alpha & na & na & $\begin{array}{l}\text { gift from N. } \\
\text { Landau }\end{array}$ & NA & \\
\hline & omega & na & na & $\begin{array}{l}\text { gift from } \mathrm{N} \\
\text { Landau }\end{array}$ & NA & \\
\hline & pBabeCXCR4puro & na & na & $\begin{array}{l}\text { gift from } \mathrm{N} \\
\text { Landau }\end{array}$ & NA & \\
\hline & pcCXCR4 & pcDNA3 (EcoRI) & $\begin{array}{c}\text { CXCR4 from } \\
\text { pBabeCXCR4puro (EcoRI) }\end{array}$ & GV & $\mathrm{C}-4$ & \\
\hline \multicolumn{7}{|c|}{ MoMLV Plasmids } \\
\hline & pUC-Env & pUC18 (PmlI, EcoRI) & $\begin{array}{l}\text { MoMLV env } \\
\text { (PmlI, EcoRI) }\end{array}$ & $\mathrm{BR}$ & NA & \\
\hline & FL-39-4b & pUC18 Env & ExSite Mutagenesis & FL & NA & pUC-Env del RBS \\
\hline \multicolumn{7}{|c|}{3 plasmid system } \\
\hline & 3240 & $\begin{array}{l}\text { pcDNA3_delNeo (filled } \\
\text { HindIII, filled EcoR1) }\end{array}$ & $\begin{array}{l}\text { MoMLV gag (del_psi) \& } \\
\text { pol (BssHII, BspEI filled) }\end{array}$ & $\mathrm{TZ}$ & $\mathrm{C}-5$ & $\begin{array}{c}\text { 893/8213-8264, 1-214, (+g)564-6513/939; } \\
\text { D135A, del psi }\end{array}$ \\
\hline & 3245 & $\begin{array}{l}\text { pcDNA3_delNeo (filled } \\
\text { HindIII, filled EcoR1) }\end{array}$ & MoMLV env (BssHII, ?) & $\mathrm{TZ}$ & $\mathrm{C}-6$ & $893 / 8213-8264,1-214(+\mathrm{gc}), 5403-7776 / 938$ \\
\hline & GV-1 & 3245 (PmlI, BspEI) & FL-28 (PmlI, BspEI) & GV & $\mathrm{C}-7$ & $\begin{array}{c}\text { Sst/RBS Env (Sst-14 replacing MoMLV } \\
\text { RBS) }\end{array}$ \\
\hline & GV-2 & 3245 (PmlI, BspEI) & MS-10 (PmlI, BspEI) & GV & $\mathrm{C}-8$ & Sst/RBS-R95D Env \\
\hline
\end{tabular}


Table C-1 (continued).

\begin{tabular}{|c|c|c|c|c|c|c|}
\hline Category & Construct Name & Backbone & Insert & $\begin{array}{c}\text { Constructed } \\
\text { By }\end{array}$ & Map & Notes \\
\hline \multicolumn{7}{|c|}{$\begin{array}{l}\text { MoMLV Plasmids } \\
\text { (continued) } \\
3 \text { plasmid system } \\
\text { (continued) }\end{array}$} \\
\hline & GV-31 & GV-2 (BspEI, EcoRI) & 838 (BspE1, EcoRI) & GV & C-9 & Sst/RBS-R95D-Q227R-D243Y Env \\
\hline & GV-41 & GV-2 (BspEI, EcoRI) & 2027 (BspEI, EcoRI) & GV & $\mathrm{C}-10$ & Sst/RBS-R95D-Q227R Env \\
\hline & GV-51 & GV-2 (BspEI, EcoRI) & 2059 (BspEI, EcoRI) & GV & $\mathrm{C}-11$ & Sst/RBS-R95D-D243Y Env \\
\hline & GV-6 & 3240 (HpaI, filled BspEI) & self ligation & GV & $\mathrm{C}-12$ & $\begin{array}{l}\text { reduced amount of env gene in original } \\
3240 \text { construct }\end{array}$ \\
\hline & TS45 & 3245 & Mutagenesis & TS & $\mathrm{C}-13$ & perfect splice donor, perfect splice acceptor \\
\hline & SDF-1a/RBS A & $\begin{array}{l}3245+\text { A flanking } \\
\text { sequence (HindIII) }\end{array}$ & $\begin{array}{l}\text { SDF-1a - flanking } \\
\text { sequence (HindIII) }\end{array}$ & GV & $\mathrm{C}-14$ & SDF-1a replacing MoMLV RBS \\
\hline & SDF-1a/RBS B & $\begin{array}{l}3245+\text { B flanking } \\
\text { sequence (HindIII) }\end{array}$ & $\begin{array}{l}\text { SDF-1a - flanking } \\
\text { sequence (HindIII) }\end{array}$ & GV & $\mathrm{C}-15$ & SDF-1a replacing MoMLV RBS \\
\hline & SDF-1a/RBS C & $\begin{array}{l}3245+\text { C flanking } \\
\text { sequence (HindIII) }\end{array}$ & $\begin{array}{l}\text { SDF-1a - flanking } \\
\text { sequence (HindIII) }\end{array}$ & GV & C-16 & SDF-1a replacing MoMLV RBS \\
\hline & SDF-1a/RBS D & $\begin{array}{l}3245+\text { D flanking } \\
\text { sequence (HindIII) }\end{array}$ & $\begin{array}{l}\text { SDF-1a - flanking } \\
\text { sequence (HindIII) }\end{array}$ & GV & $\mathrm{C}-17$ & SDF-1a replacing MoMLV RBS \\
\hline & SDF-1a/RBS E & $\begin{array}{l}3245+\text { E flanking sequence } \\
\text { (HindIII) }\end{array}$ & $\begin{array}{l}\text { SDF-1a - flanking } \\
\text { sequence (HindIII) }\end{array}$ & GV & $\mathrm{C}-18$ & SDF-1a replacing MoMLV RBS \\
\hline & SDF-1a/RBS G & $\begin{array}{l}3245+\mathrm{G} \text { flanking } \\
\text { sequence (HindIII) }\end{array}$ & $\begin{array}{l}\text { SDF-1a - flanking } \\
\text { sequence (HindIII) }\end{array}$ & GV & C-19 & SDF-1a inserted just before MoMLV RBS \\
\hline & (Q123) 3245_R-less & 3245 & R-less & ZQ & $\mathrm{C}-20$ & $\begin{array}{c}893 / 8213-8264,1-214(+\mathrm{gc}), 5403- \\
7859 / 938 ; \mathrm{V} 616^{*}\end{array}$ \\
\hline & TS45_R-less & TS45 (BamHI, EcoRI) & Q123 (BamH1, EcoRI) & LA & $\mathrm{C}-21$ & $\begin{array}{l}\text { perfect splice donor, perfect splice acceptor, } \\
\text { V616* }\end{array}$ \\
\hline & GV-1_R-less & GV-1 (BamHI, EcoRI) & TS45 (BamH1, EcoRI) & LA & $\mathrm{C}-22$ & Sst/RBS-V616* \\
\hline & $\begin{array}{l}\text { RGD-14/RBS R-less } \\
\quad(45 / 51 \text { A mp2) }\end{array}$ & $\begin{array}{l}\text { TS45_R-less } \\
\text { (BstEII, BamHI) }\end{array}$ & $\begin{array}{l}\text { PCR amplified LR51A } \\
\text { RBS (BstEII, BamHI) }\end{array}$ & GV & $\mathrm{C}-23$ & RGD-14 replacing MoMLV RBS \\
\hline & $\begin{array}{l}\text { Cys-Bombesin-1/RBS R-less } \\
\text { (45/67 mp2) }\end{array}$ & $\begin{array}{l}\text { TS45_R-less } \\
\text { (BstEII, BamHI) }\end{array}$ & $\begin{array}{l}\text { PCR amplified FL67 RBS } \\
\text { (BstEII, BamHI) }\end{array}$ & GV & $\mathrm{C}-24$ & $\begin{array}{c}\text { Bombesin-1 flanked by Cys replacing } \\
\text { MoMLV RBS }\end{array}$ \\
\hline & $\begin{array}{l}\text { Cys-Bombesin-2/RBS R-less } \\
\text { (45/68 mp2) }\end{array}$ & $\begin{array}{l}\text { TS45_R-less } \\
\text { (BstEII, BamHI) }\end{array}$ & $\begin{array}{l}\text { PCR amplified FL68 RBS } \\
\text { (BstEII, BamHI) }\end{array}$ & GV & $\mathrm{C}-25$ & $\begin{array}{c}\text { Bombesin-2 flanked by Cys replacing } \\
\text { MoMLV RBS }\end{array}$ \\
\hline
\end{tabular}


Table C-1 (continued).

\begin{tabular}{|c|c|c|c|c|c|c|}
\hline Category & Construct Name & Backbone & Insert & $\begin{array}{c}\text { Constructed } \\
\text { By }\end{array}$ & Map & Notes \\
\hline \multicolumn{7}{|c|}{$\begin{array}{l}\text { MoMLV Plasmids } \\
\text { (continued) } \\
3 \text { plasmid system } \\
\text { (continued) }\end{array}$} \\
\hline & $\begin{array}{l}\text { Cys-RGD-14/RBS R-less } \\
(45 / 59 \mathrm{mp} 2)\end{array}$ & $\begin{array}{c}\text { TS45_R-less } \\
\text { (BstEII, BamHI) }\end{array}$ & $\begin{array}{l}\text { PCR amplified FL59 RBS } \\
\text { (BstEII, BamHI) }\end{array}$ & GV & $\mathrm{C}-26$ & $\begin{array}{c}\text { RGD-14 flanked by Cys replacing MoMLV } \\
\text { RBS }\end{array}$ \\
\hline & $\begin{array}{l}\text { SP-11/RBS R-less } \\
\quad(45 / 53 \mathrm{mp} 3)\end{array}$ & $\begin{array}{l}\text { TS45_R-less } \\
\text { (BstEII, BamHI) }\end{array}$ & $\begin{array}{l}\text { PCR amplified LS53 RBS } \\
\text { (BstEII, BamHI) }\end{array}$ & $\mathrm{GV}$ & $\mathrm{C}-27$ & SP-11 replacing MoMLV RBS \\
\hline & $\begin{array}{l}\text { Neurotensin/RBS R-less } \\
\quad(45 / 54 \mathrm{mp} 3)\end{array}$ & $\begin{array}{c}\text { TS45_R-less } \\
\text { (BstEII, BamHI) }\end{array}$ & $\begin{array}{l}\text { PCR amplified LN54 RBS } \\
\text { (BstEII, BamHI) }\end{array}$ & GV & $\mathrm{C}-28$ & Neurotensin replacing MoMLV RBS \\
\hline & $\begin{array}{l}\text { Oxytocin/RBS R-less } \\
\quad(45 / 49 \mathrm{mp} 3)\end{array}$ & $\begin{array}{l}\text { TS45_R-less } \\
\text { (BstEII, BamHI) }\end{array}$ & $\begin{array}{l}\text { PCR amplified LO49 RBS } \\
\text { (BstEII, BamHI) }\end{array}$ & GV & C-29 & Oxytocin replacing MoMLV RBS \\
\hline & $\begin{array}{l}\text { Bombesin-14/RBS R-less } \\
(45 / 56-5 \mathrm{mp} 3)\end{array}$ & $\begin{array}{l}\text { TS45_R-less } \\
\text { (BstEII, BamHI) }\end{array}$ & $\begin{array}{l}\text { PCR amplified LB56-5 } \\
\text { RBS (BstEII, BamHI) }\end{array}$ & GV & $\mathrm{C}-30$ & Bombesin replacing MoMLV RBS \\
\hline & $\begin{array}{l}\text { Endothelin/RBS R-less } \\
\qquad(45 / 50 \mathrm{mp} 3)\end{array}$ & $\begin{array}{c}\text { TS45_R-less } \\
\text { (BstEII, BamHI) }\end{array}$ & $\begin{array}{l}\text { PCR amplified LE50 RBS } \\
\text { (BstEII, BamHI) }\end{array}$ & GV & $\mathrm{C}-31$ & Endothelin replacing MoMLV RBS \\
\hline & $\begin{array}{l}\text { TS45_delRBS_R-less } \\
\quad(45 / 39-4 \mathrm{~b} \mathrm{mp} 2)\end{array}$ & $\begin{array}{l}\text { TS45_R-less (BstEII, } \\
\text { BamHI) }\end{array}$ & $\begin{array}{l}\text { PCR amplified FL-39-4b } \\
\text { RBS (BstEII, BamHI) }\end{array}$ & GV & $\mathrm{C}-32$ & delRBS_R-less Env \\
\hline & TS45_delRBS & TS45 (BstEII, BamHI) & $\begin{array}{l}\text { PCR amplified FL-39-4b } \\
\text { RBS (BstEII, BamHI) }\end{array}$ & GV & $\mathrm{C}-33$ & delRBS Env \\
\hline & GVTS45 & TS45 & filled MluI site (acgccgcgt) & $\mathrm{GV}$ & $\mathrm{C}-34$ & $\begin{array}{l}\text { perfect splice donor, perfect splice acceptor, } \\
\text { enhanced promoter activity, }+\mathrm{c}\end{array}$ \\
\hline & GVTS45_delRBS & GVTS45 (PmlI, BspEI) & $\begin{array}{l}\text { PCR amplified TS45_del } \\
\text { RBS_R-less (PmlI, BspEI) }\end{array}$ & GV & $\mathrm{C}-35$ & $\begin{array}{l}\text { perfect splice donor, perfect splice acceptor, } \\
\text { enhanced promoter activity, delRBS }\end{array}$ \\
\hline & TS45/HBS-1 & TS45 & ExSite Mutagenesis & GV & $\mathrm{C}-36$ & E127K \\
\hline & TS45/HBS-2 & TS45 & ExSite Mutagenesis & $\mathrm{GV}$ & $\mathrm{C}-37$ & E127R \\
\hline & TS45/HBS-3 & TS45 & ExSite Mutagenesis & GV & $\mathrm{C}-38$ & $\mathrm{E} 127 \mathrm{H}$ \\
\hline & TS45/HBS-4 & TS45 & ExSite Mutagenesis & GV & C-39 & all $\mathrm{B}=\mathrm{K}$ \\
\hline & TS45/HBS-5 & TS45 & ExSite Mutagenesis & GV & $\mathrm{C}-40$ & all $\mathrm{B}=\mathrm{R}$ \\
\hline & TS45/HBS-6 & TS45 & ExSite Mutagenesis & GV & C-41 & all $\mathrm{B}=\mathrm{RorH}$ \\
\hline & TS45/HBS-7 & TS45 & ExSite Mutagenesis & GV & C-42 & all $\mathrm{B}=\mathrm{KorH}$ \\
\hline & TS45/HBS-8 & TS45 & ExSite Mutagenesis & $\mathrm{GV}$ & C-43 & all $\mathrm{B}=\mathrm{A}$ \\
\hline
\end{tabular}


Table C-1 (continued).

\begin{tabular}{|c|c|c|c|c|c|c|}
\hline Category & Construct Name & Backbone & Insert & $\begin{array}{c}\text { Constructed } \\
\text { By }\end{array}$ & Map & Notes \\
\hline \multirow{2}{*}{\multicolumn{7}{|c|}{$\begin{array}{l}\text { MoMLV Plasmids } \\
\text { (continued) } \\
\text { 2 plasmid system }\end{array}$}} \\
\hline & & & & & & \\
\hline & 752 & pcDNA3_delNeo & $\begin{array}{l}\text { MoMLV gag (del_psi), } \\
\text { pol, env }\end{array}$ & $\mathrm{TZ}$ & $\mathrm{Y}$ & $\begin{array}{l}\text { MoMLV gag, pol, env in pcDNA3_delNeo } \\
\text { (pcDNA_MoMLV) }\end{array}$ \\
\hline & FL-28 & 752 & Sst-14 & FL & $\mathrm{Y}$ & Sst/RBS \\
\hline & MS-10 & FL-28 & QuikChange Mutagenesis & MS & NA & Sst/RBS-R95D \\
\hline & H8R & 752 & QuikChange Mutagenesis & $\mathrm{JF}$ & NA & $\mathrm{H} 8 \mathrm{R}$ \\
\hline & 838 & 752 (PmlI, NsiI) & $\begin{array}{l}\text { Natural Env Mutant } \\
\quad \text { (PmlI, NsiI) }\end{array}$ & $\mathrm{TZ}$ & NA & H8R-Q227R-D243Y \\
\hline & 2027 & H8R & $\begin{array}{l}\text { Oligo Site-directed } \\
\text { Mutagenesis }\end{array}$ & $\mathrm{TZ}$ & NA & H8R-Q227R \\
\hline & 2059 & 752 & $\begin{array}{l}\text { Oligo Site-directed } \\
\text { Mutagenesis }\end{array}$ & $\mathrm{TZ}$ & NA & $\mathrm{D} 243 \mathrm{Y}$ \\
\hline & LB56-5 & 752 & Bombesin & FL & $\mathrm{Y}$ & Bombesin replacing MoMLV RBS \\
\hline & FL67 & 752 & Cys-Bombesin-1-Cys & FL & $\mathrm{Y}$ & $\begin{array}{c}\text { Bombesin-1 flanked by Cys replacing } \\
\text { MoMLV RBS }\end{array}$ \\
\hline & FL68 & 752 & Cys-Bombesin-2-Cys & FL & $\mathrm{Y}$ & $\begin{array}{c}\text { Bombesin-2 flanked by Cys replacing } \\
\text { MoMLV RBS }\end{array}$ \\
\hline & LR51A & 752 & RGD-14 & FL & $\mathrm{Y}$ & RGD-14 replacing MoMLV RBS \\
\hline & FL59 & 752 & Cys-RGD14-Cys & FL & $\mathrm{Y}$ & $\begin{array}{c}\text { RGD-14 flanked by Cys replacing MoMLV } \\
\text { RBS }\end{array}$ \\
\hline & LN54 & 752 & Neurotensin & FL & $\mathrm{Y}$ & Neurotensin replacing MoMLV RBS \\
\hline & LO49 & 752 & Oxytocin & FL & $\mathrm{Y}$ & Oxytocin replacing MoMLV RBS \\
\hline & LE50 & 752 & Endothelin & FL & $\mathrm{Y}$ & Endothelin replacing MoMLV RBS \\
\hline & LS53 & 752 & SP-11 & FL & $\mathrm{Y}$ & SP-11 replacing MoMLV RBS \\
\hline & GV752 & 752 (EcoRI, SnaBI) & $\begin{array}{l}\text { PCR Amplified GVTS45 } \\
\text { fragment (EcoRI, SnaBI) }\end{array}$ & GV & Y & enhanced promoter activity \\
\hline
\end{tabular}


Table C-1 (continued).

\begin{tabular}{|c|c|c|c|c|c|c|}
\hline Category & Construct Name & Backbone & Insert & $\begin{array}{c}\text { Constructed } \\
\text { By }\end{array}$ & Map & Notes \\
\hline \multicolumn{7}{|c|}{$\begin{array}{l}\text { MoMLV Plasmids } \\
\text { (continued) } \\
2 \text { plasmid system } \\
\text { (continued) }\end{array}$} \\
\hline & GV752_delRBS & GV752 (PmlI, BspEI) & $\begin{array}{c}\text { PCR amplified } \\
\text { TS45_delRBS_R-less } \\
\text { fragment (PmlI, BspEI) }\end{array}$ & GV & $\mathrm{Y}$ & delRBS, enhanced promoter activity \\
\hline & GV752/HBS-1 & GV752 & $\begin{array}{l}\text { PCR Amplified } \\
\text { TS45/HBS-1 fragment } \\
\text { (PmlI, BspEI) } \\
\text { PCR Amplified }\end{array}$ & GV & $\mathrm{Y}$ & $\mathrm{E} 127 \mathrm{~K}$ \\
\hline & GV752/HBS-2 & GV752 & $\begin{array}{l}\text { TS45/HBS-2 fragment } \\
\text { (PmlI, BspEI) } \\
\text { PCR Amplified }\end{array}$ & GV & $\mathrm{Y}$ & E127R \\
\hline & GV752/HBS-3 & GV752 & $\begin{array}{l}\text { TS45/HBS-3 fragment } \\
\text { (PmlI, BspEI) } \\
\text { PCR Amplified }\end{array}$ & GV & Y & $\mathrm{E} 127 \mathrm{H}$ \\
\hline & GV752/HBS-4 & GV752 & $\begin{array}{l}\text { TS45/HBS-4 fragment } \\
\text { (PmlI, BspEI) } \\
\text { PCR Amplified }\end{array}$ & GV & Y & all $\mathrm{B}=\mathrm{K}$ \\
\hline & GV752/HBS-5 & GV752 & $\begin{array}{l}\text { TS45/HBS-5 fragment } \\
\text { (PmII, BspEI) } \\
\text { PCR Amplified }\end{array}$ & GV & Y & all $B=R$ \\
\hline & GV752/HBS-6 & GV752 & $\begin{array}{l}\text { TS45/HBS-6 fragment } \\
\text { (PmlI, BspEI) } \\
\text { PCR Amplified }\end{array}$ & GV & $\mathrm{Y}$ & all $\mathrm{B}=$ RorH \\
\hline & GV752/HBS-7 & GV752 & $\begin{array}{l}\text { TS45/HBS-7 fragment } \\
\text { (PmII, BspEI) } \\
\text { PCR Amnlified }\end{array}$ & GV & $\mathrm{Y}$ & all $\mathrm{B}=\mathrm{KorH}$ \\
\hline & GV752/HBS-8 & GV752 & $\begin{array}{l}\text { PCR Amplified } \\
\text { TS45/HBS-8 fragment } \\
\text { (PmII, BspEI) }\end{array}$ & GV & Y & all $\mathrm{B}=\mathrm{A}$ \\
\hline & GV752_delRBS/HBS-1 & $\begin{array}{l}\text { GV752_delRBS } \\
\text { (MluI, BspEI) }\end{array}$ & $\begin{array}{l}\text { PCR Amplified } \\
\text { TS45/HBS-1 fragment } \\
\text { (+MluI, BspEI) }\end{array}$ & GV & Y & E127K, del RBS \\
\hline & GV752_delRBS/HBS-2 & $\begin{array}{l}\text { GV752_delRBS } \\
\text { (MluI, BspEI) }\end{array}$ & $\begin{array}{c}\text { PCR Amplified } \\
\text { TS45/HBS-2 fragment } \\
\text { (+MluI, BspEI) }\end{array}$ & GV & $\mathrm{Y}$ & E127R, del RBS \\
\hline & GV752_delRBS/HBS-3 & $\begin{array}{l}\text { GV752_delRBS } \\
\text { (MluI, BspEI) }\end{array}$ & $\begin{array}{l}\text { PCR Amplified } \\
\text { TS45/HBS-3 fragment } \\
\text { (+MluI, BspEI) }\end{array}$ & GV & $\mathrm{Y}$ & E127H, del RBS \\
\hline
\end{tabular}


Table C-1 (continued).

\begin{tabular}{|c|c|c|c|c|c|c|}
\hline Category & Construct Name & Backbone & Insert & $\begin{array}{c}\text { Constructed } \\
\text { By }\end{array}$ & Map & Notes \\
\hline \multicolumn{7}{|c|}{$\begin{array}{l}\text { MoMLV Plasmids } \\
\text { (continued) } \\
2 \text { plasmid system } \\
\text { (continued) }\end{array}$} \\
\hline & GV752_delRBS/HBS-4 & $\begin{array}{l}\text { GV752_delRBS } \\
\text { (MluI, BspEI) }\end{array}$ & $\begin{array}{l}\text { PCR Amplified } \\
\text { TS45/HBS-4 fragment } \\
\text { (+MluI, BspEI) }\end{array}$ & GV & Y & all $\mathrm{B}=\mathrm{K}$, del RBS \\
\hline & GV752_delRBS/HBS-5 & $\begin{array}{c}\text { GV752_delRBS (MluI, } \\
\text { BspEI) }\end{array}$ & $\begin{array}{l}\text { PCR Amplified } \\
\text { TS45/HBS-5 fragment } \\
\text { (+MluI, BspEI) }\end{array}$ & GV & Y & all B=R, del RBS \\
\hline & GV752_delRBS/HBS-6 & $\begin{array}{c}\text { GV752_delRBS (MluI, } \\
\text { BspEI) }\end{array}$ & $\begin{array}{l}\text { PCR Amplified } \\
\text { TS45/HBS-6 fragment } \\
\text { (+MluI, BspEI) }\end{array}$ & GV & Y & all B=RorH, del RBS \\
\hline & GV752_delRBS/HBS-7 & $\begin{array}{c}\text { GV752_delRBS (MluI, } \\
\text { BspEI) }\end{array}$ & $\begin{array}{l}\text { PCR Amplified } \\
\text { TS45/HBS-7 fragment } \\
\text { (+MluI, BspEI) }\end{array}$ & $\mathrm{GV}$ & $\mathrm{Y}$ & all $\mathrm{B}=\mathrm{KorH}$, del RBS \\
\hline & GV752_delRBS/HBS-8 & $\begin{array}{c}\text { GV752_delRBS (MluI, } \\
\text { BspEI) }\end{array}$ & $\begin{array}{l}\text { PCR Amplified } \\
\text { TS45/HBS-8 fragment } \\
\text { (+MluI, BspEI) }\end{array}$ & GV & $\mathrm{Y}$ & all $\mathrm{B}=\mathrm{A}$, del RBS \\
\hline
\end{tabular}




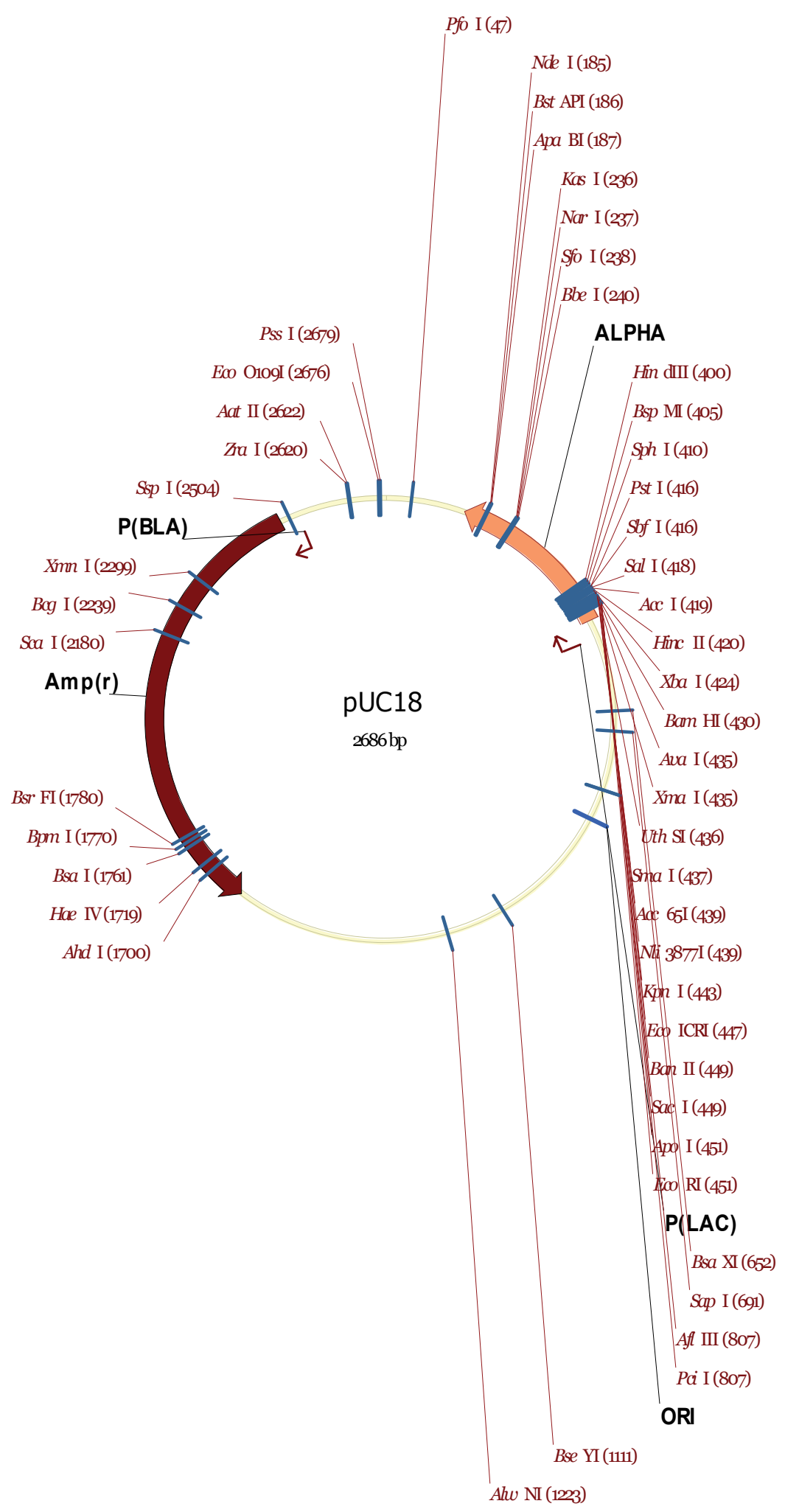

Figure C-1. pUC18. 


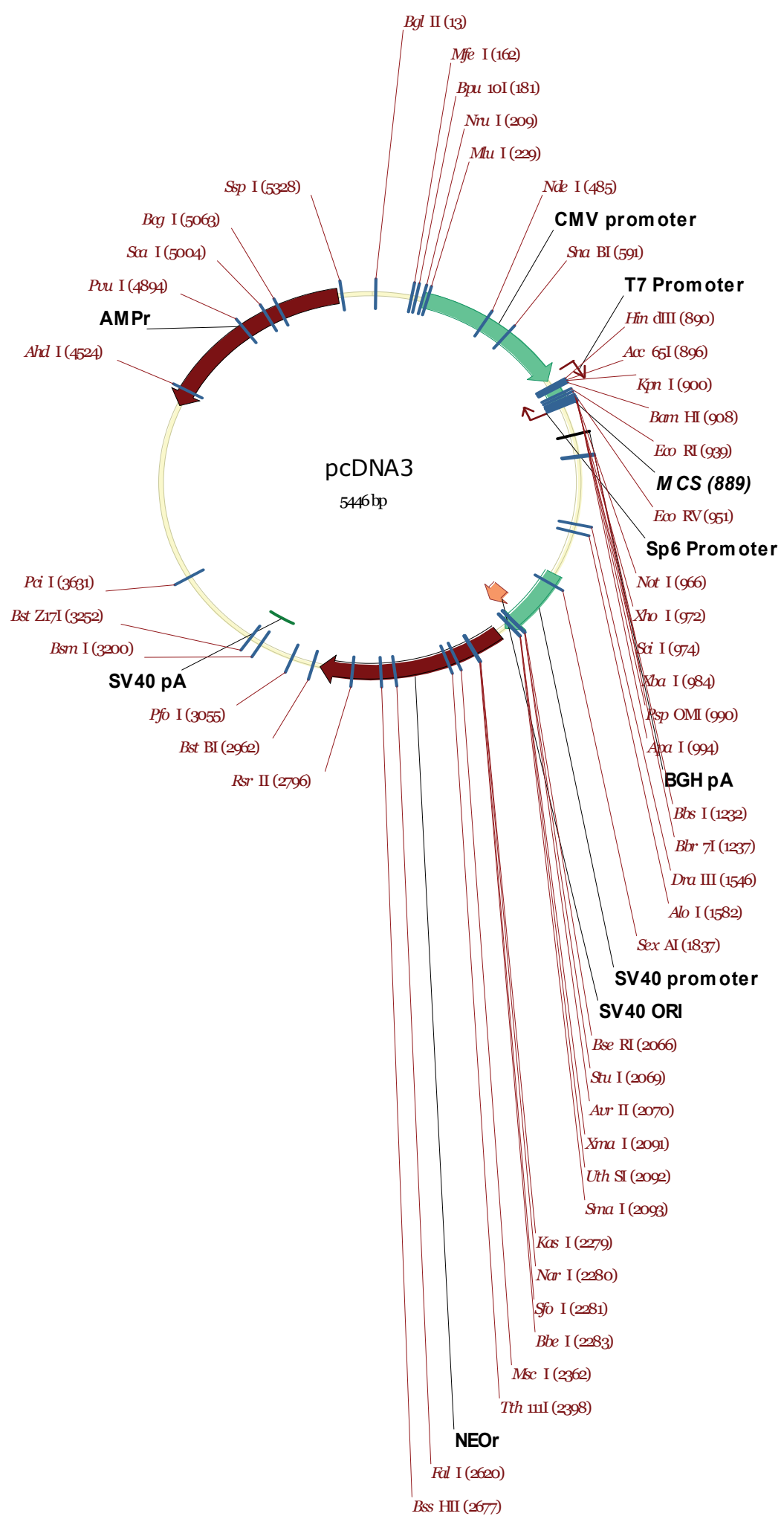

Figure C-2. pcDNA3. 


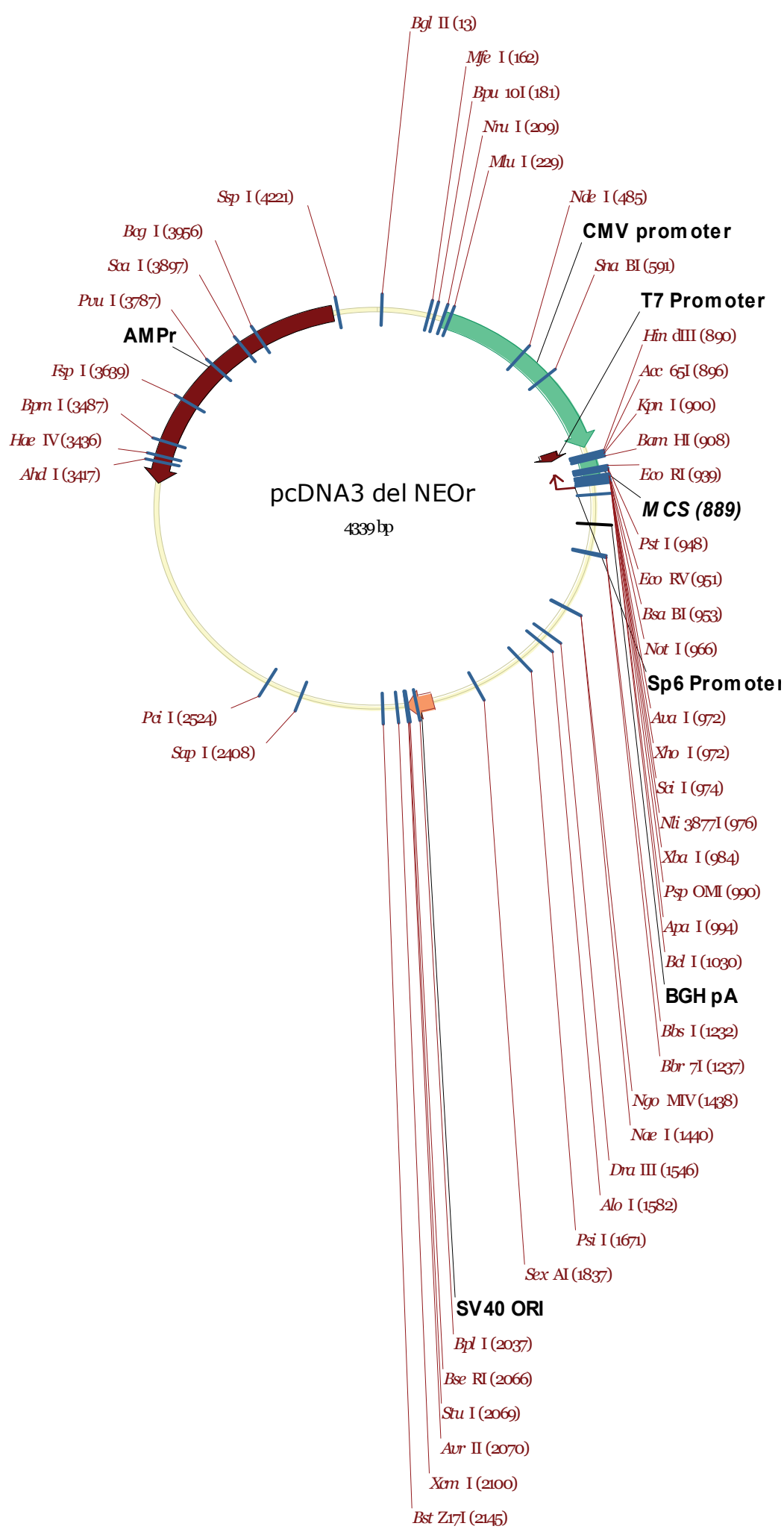

Figure C-3. pcDNA3_delNeo. 


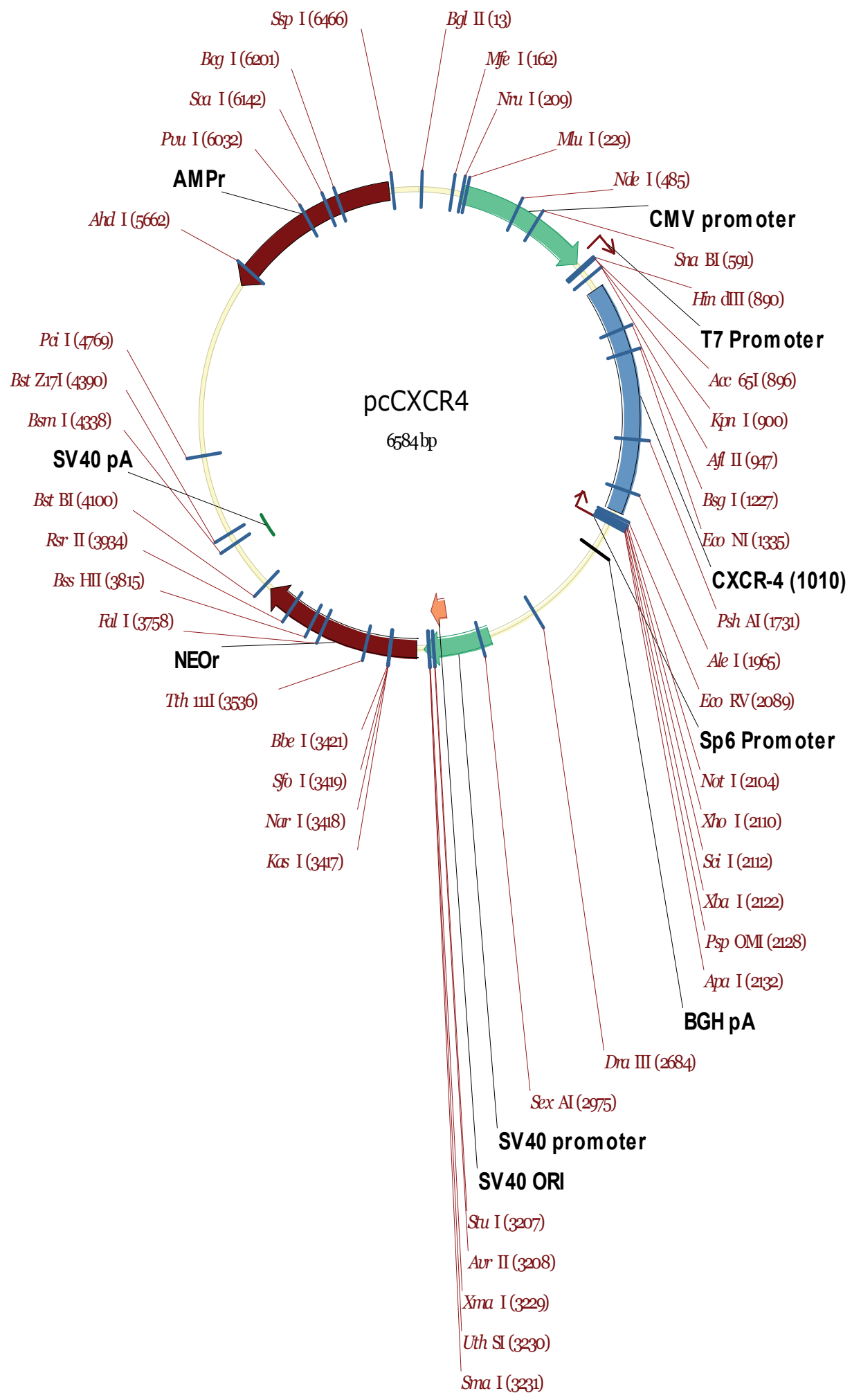

Figure C-4. pcCXCR4. 


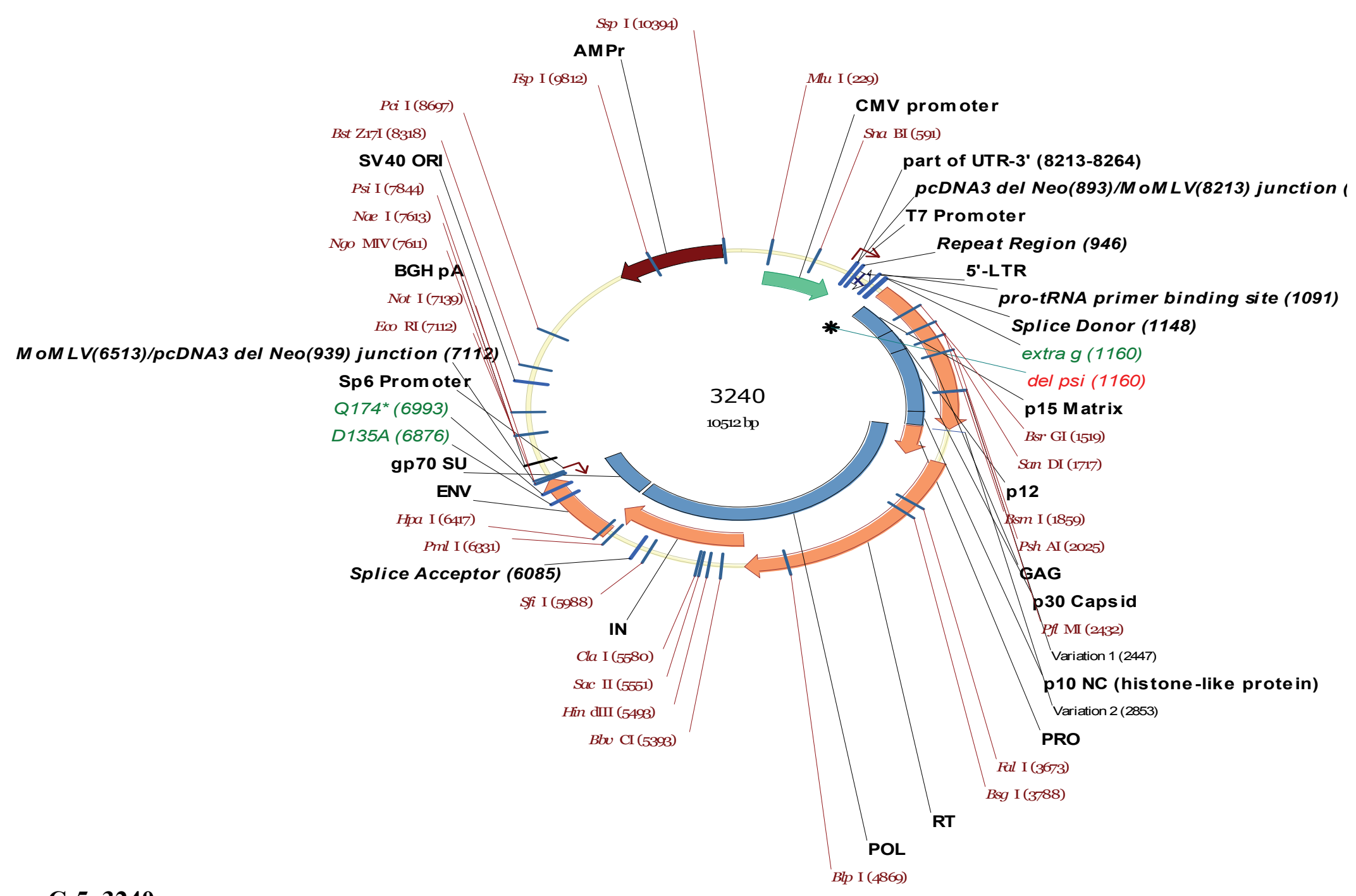

Figure C-5. 3240. 


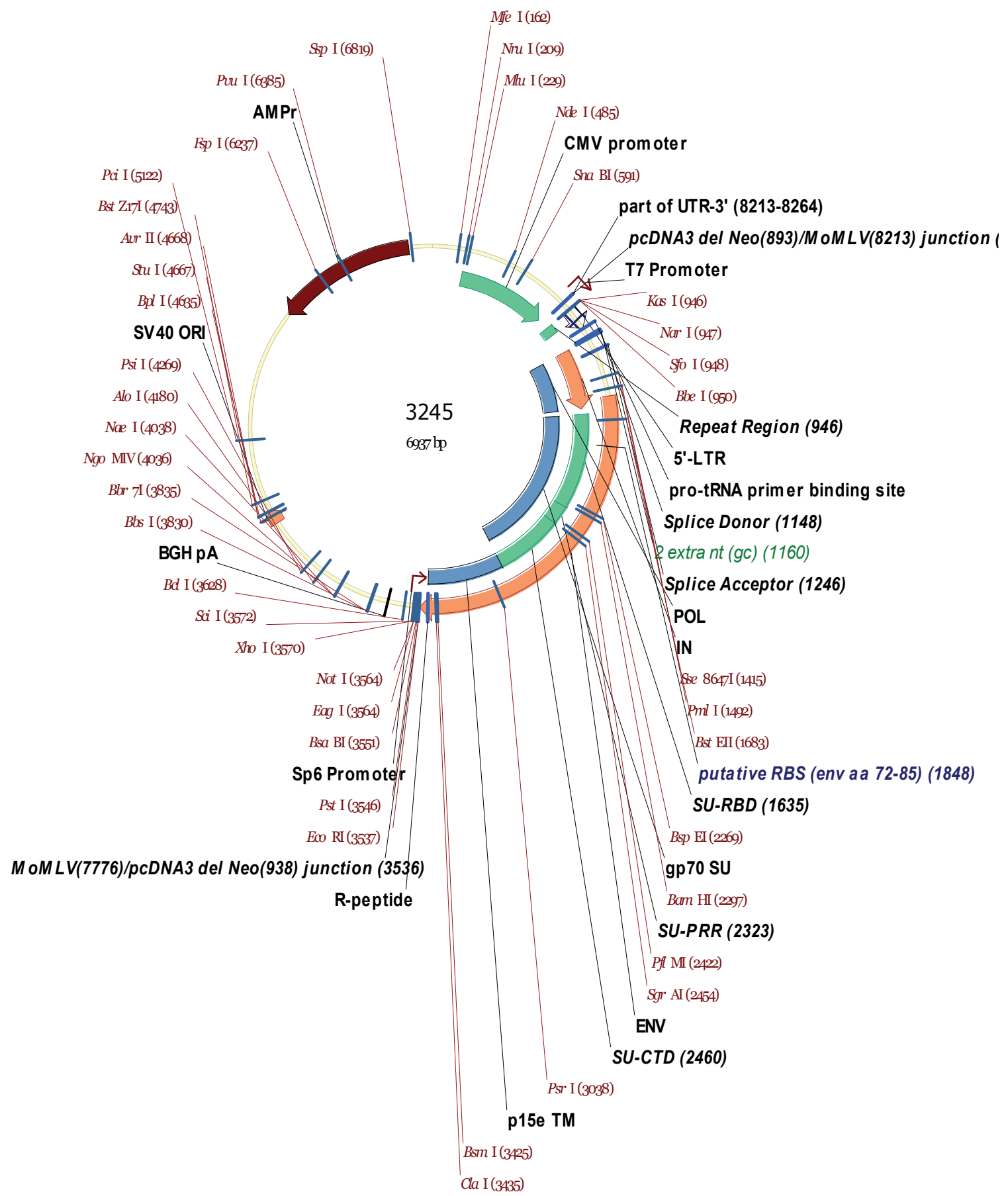

Figure C-6. 3245. 


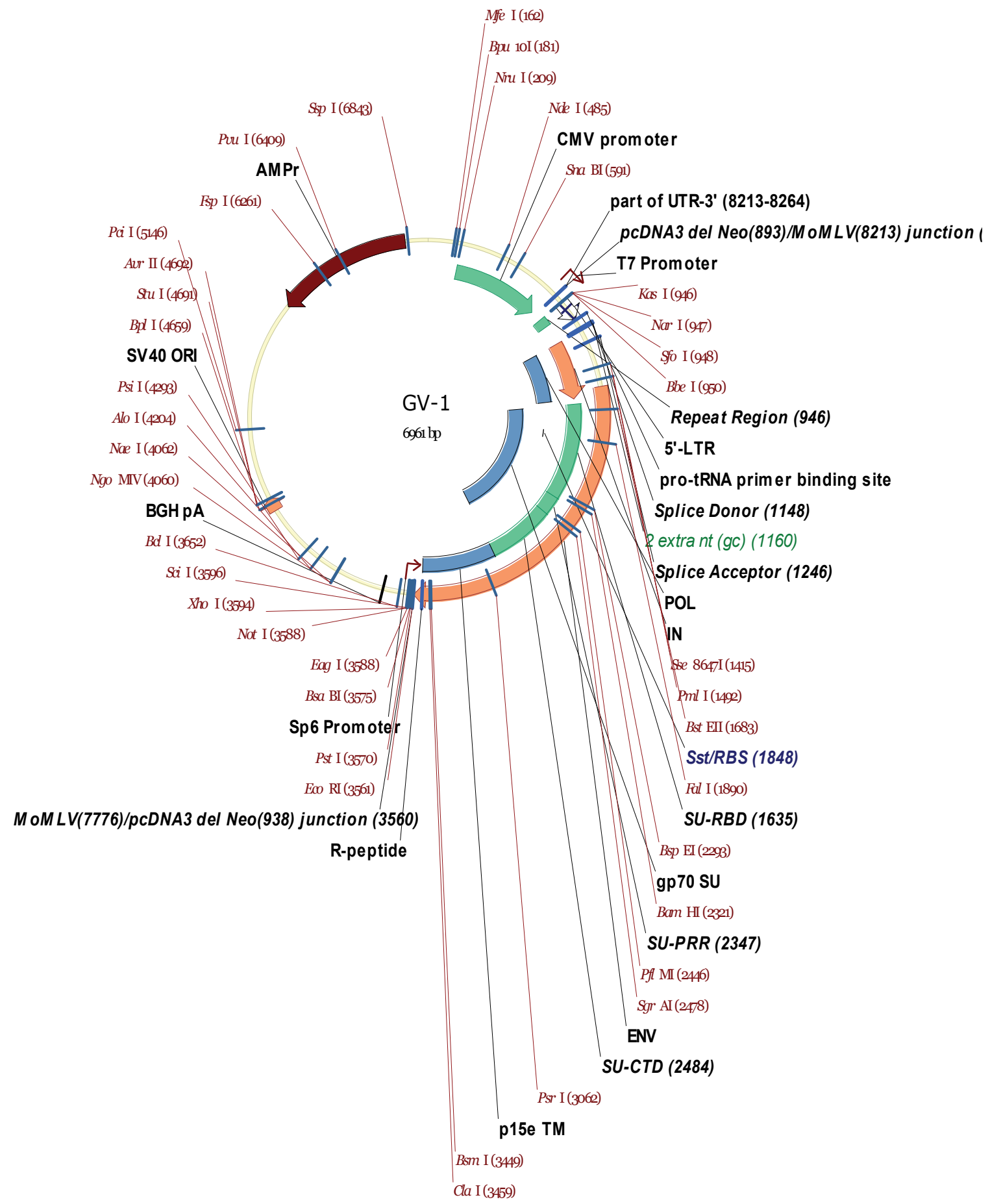

Figure C-7. GV-1. 


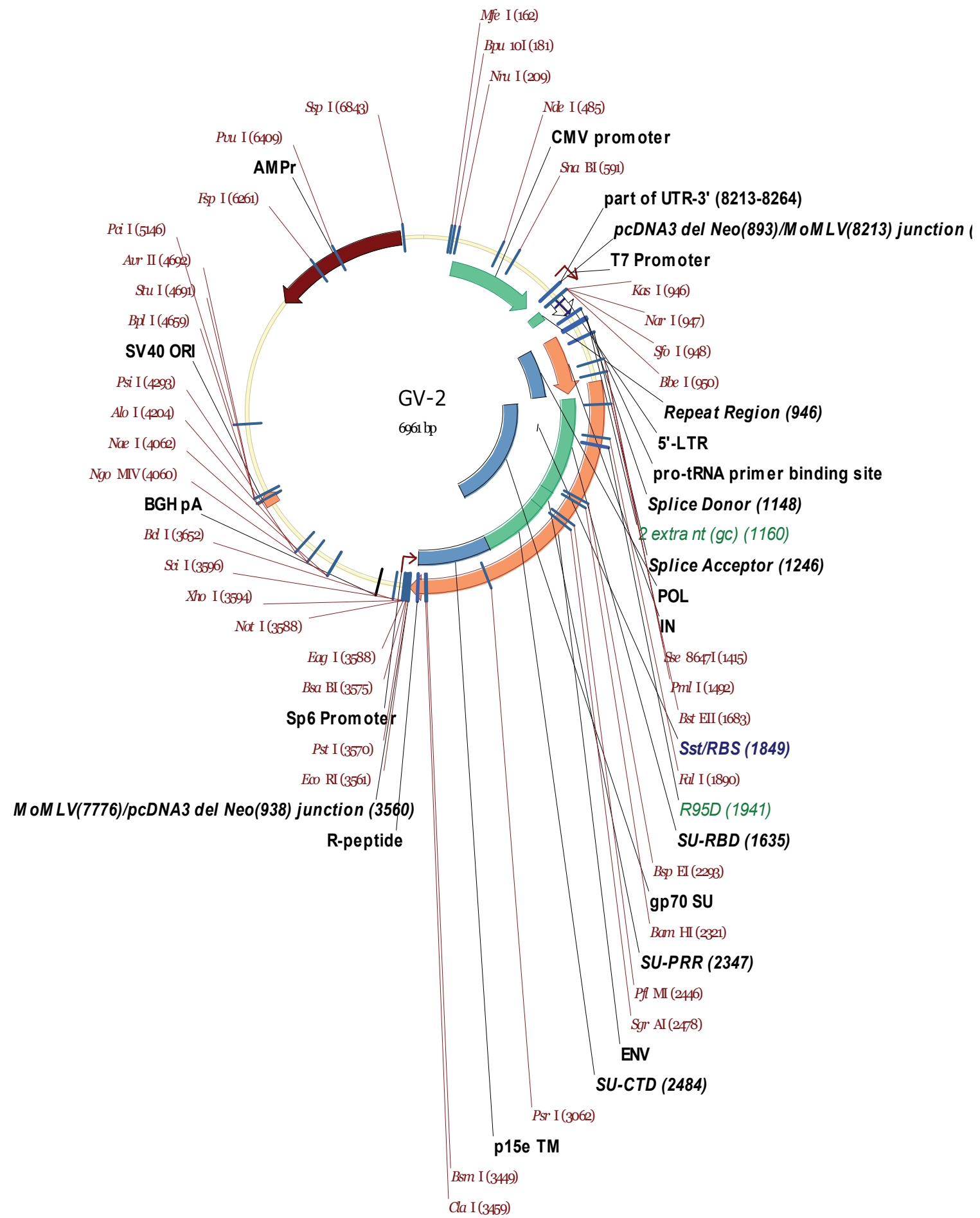

Figure C-8. GV-2. 


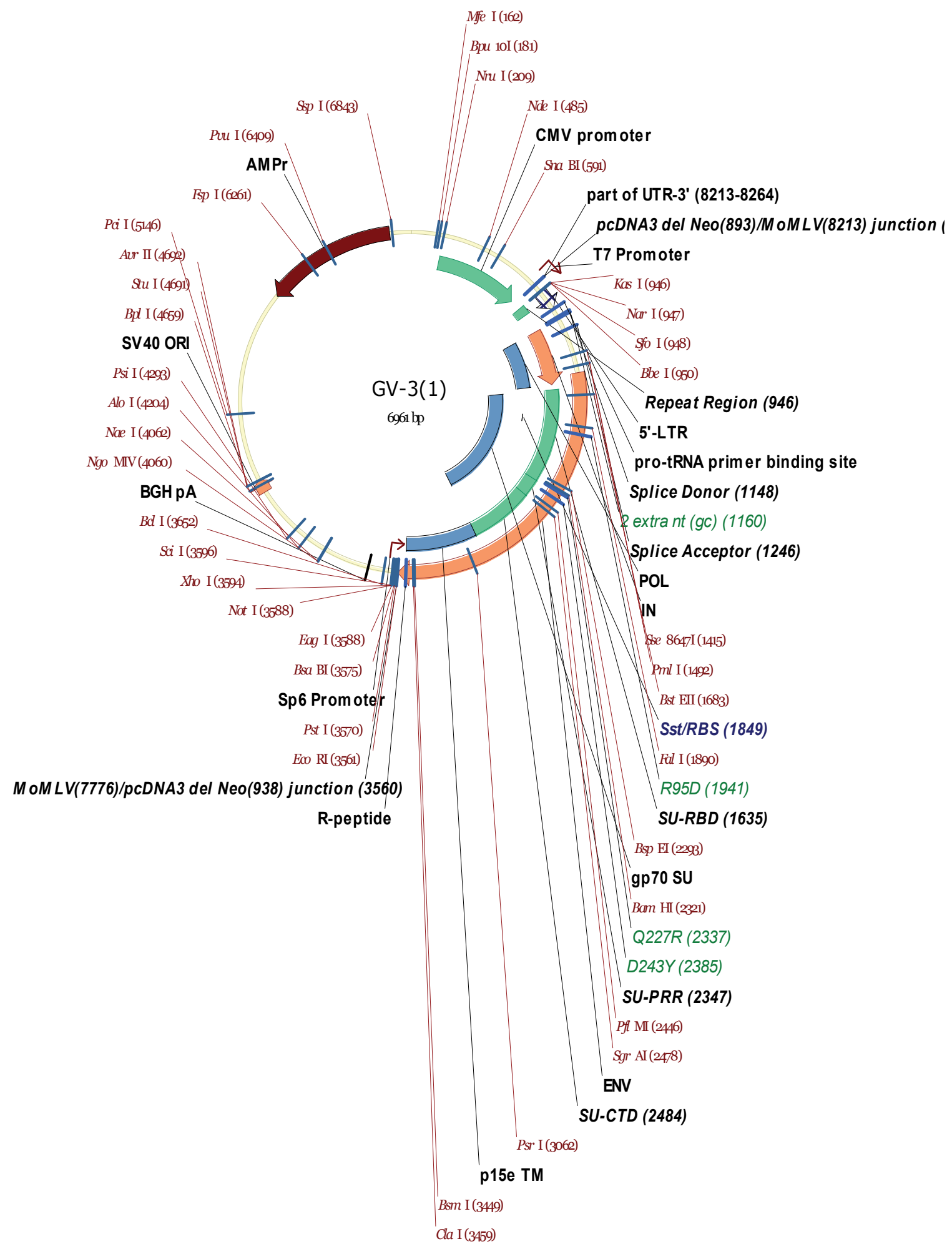

Figure C-9. GV-31. 


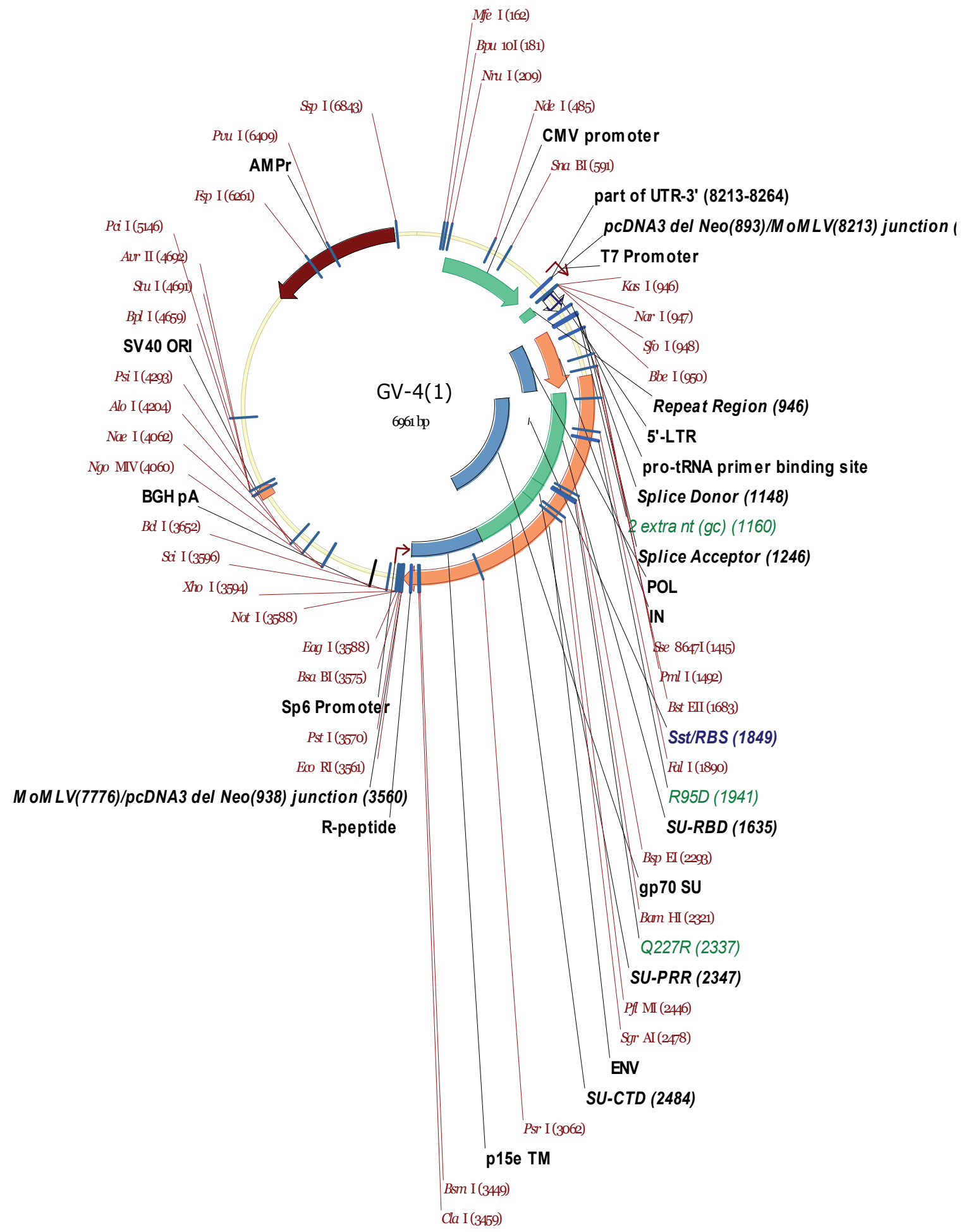

Figure C-10. GV-41. 


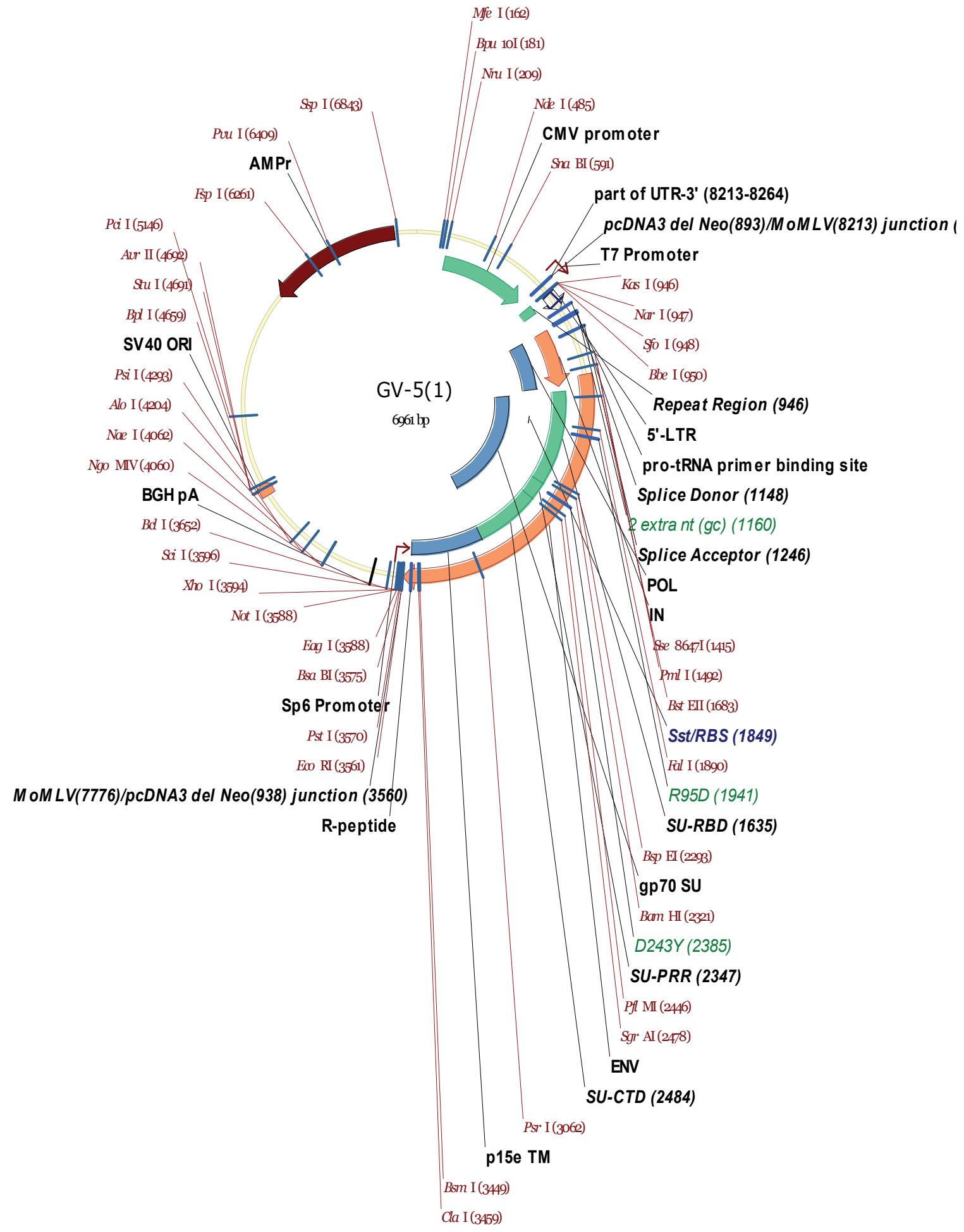

Figure C-11. GV-51. 


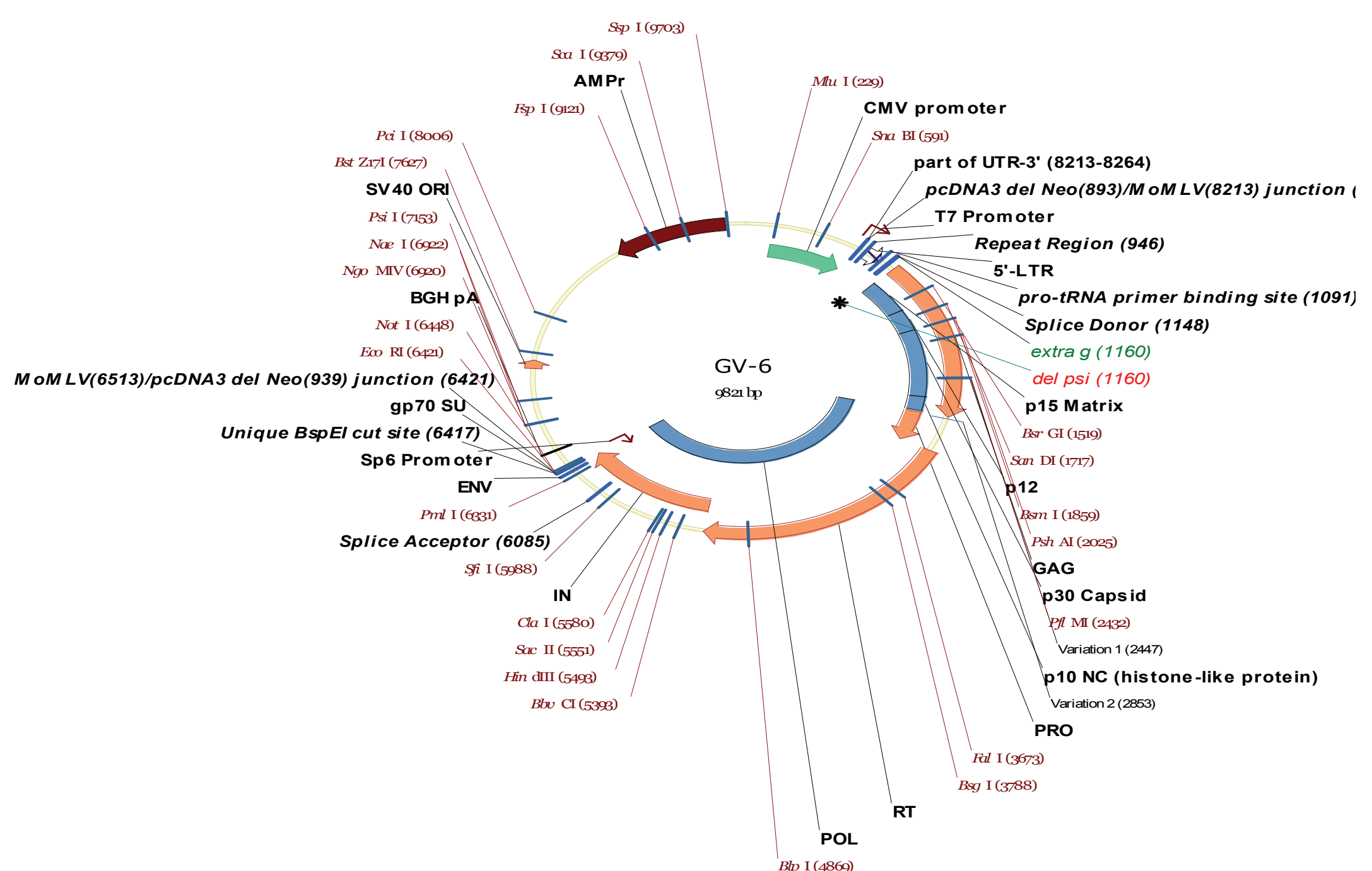

Figure C-12. GV-6. 


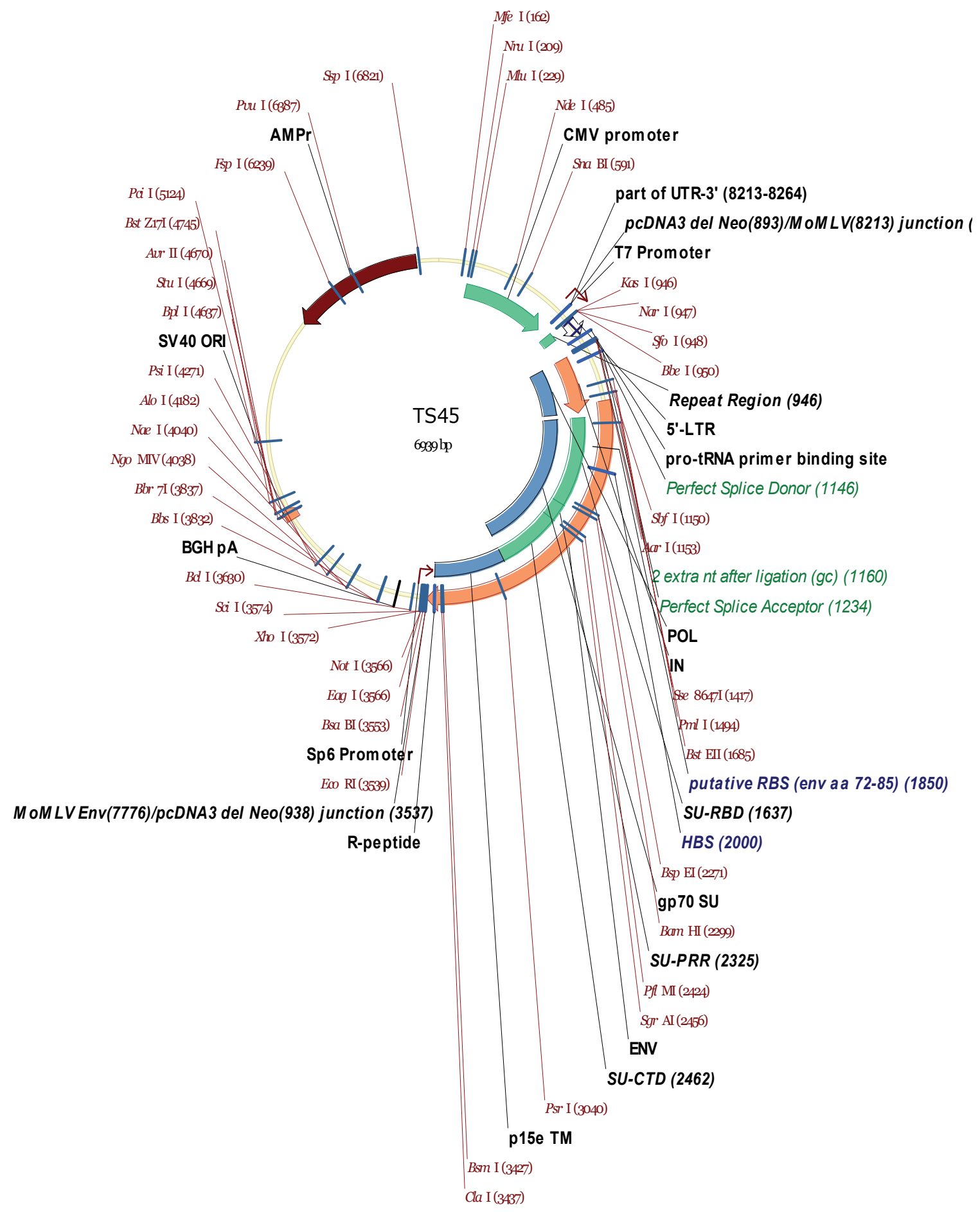

Figure C-13. TS45. 


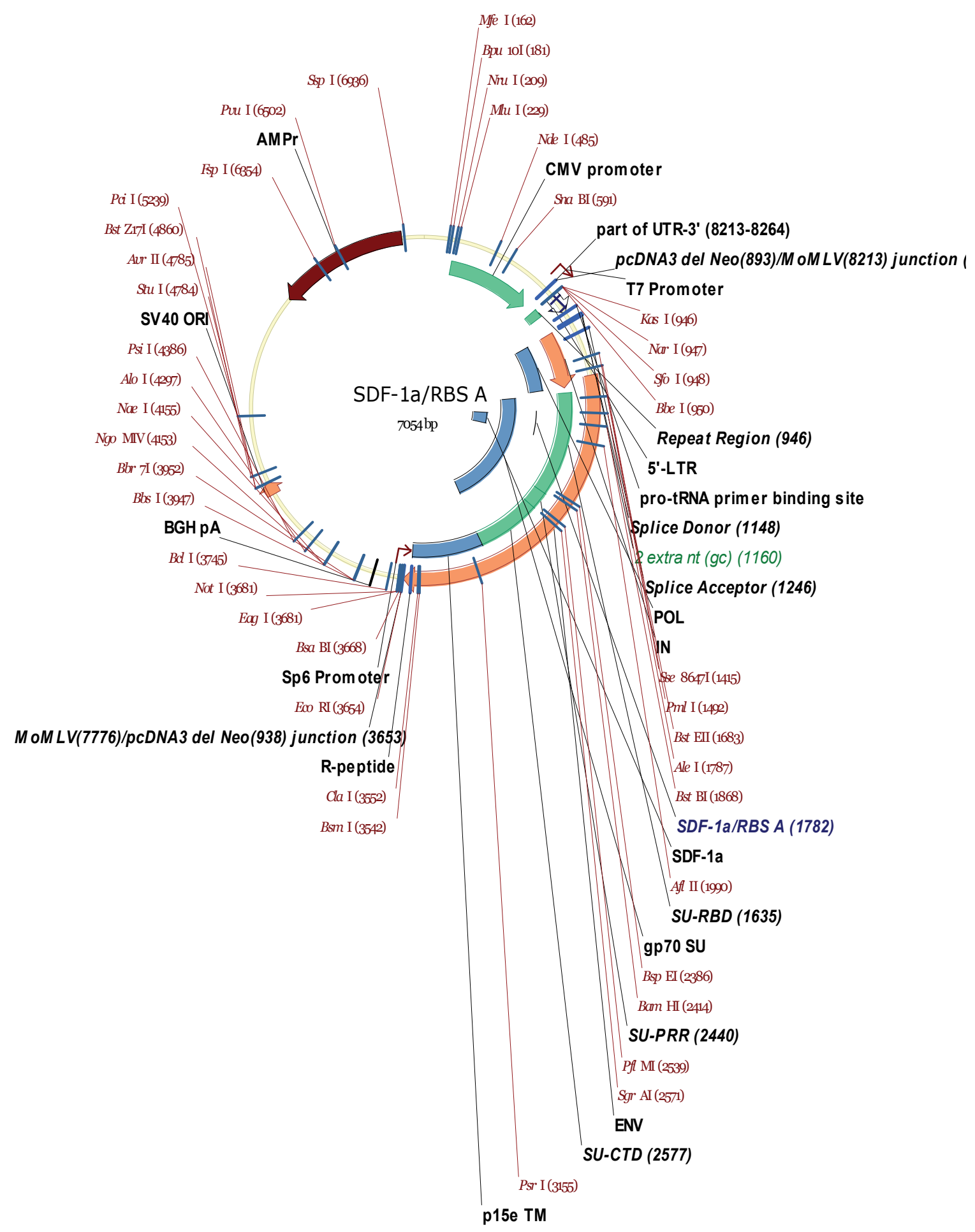

Figure C-14. SDF-1a/RBS A. 


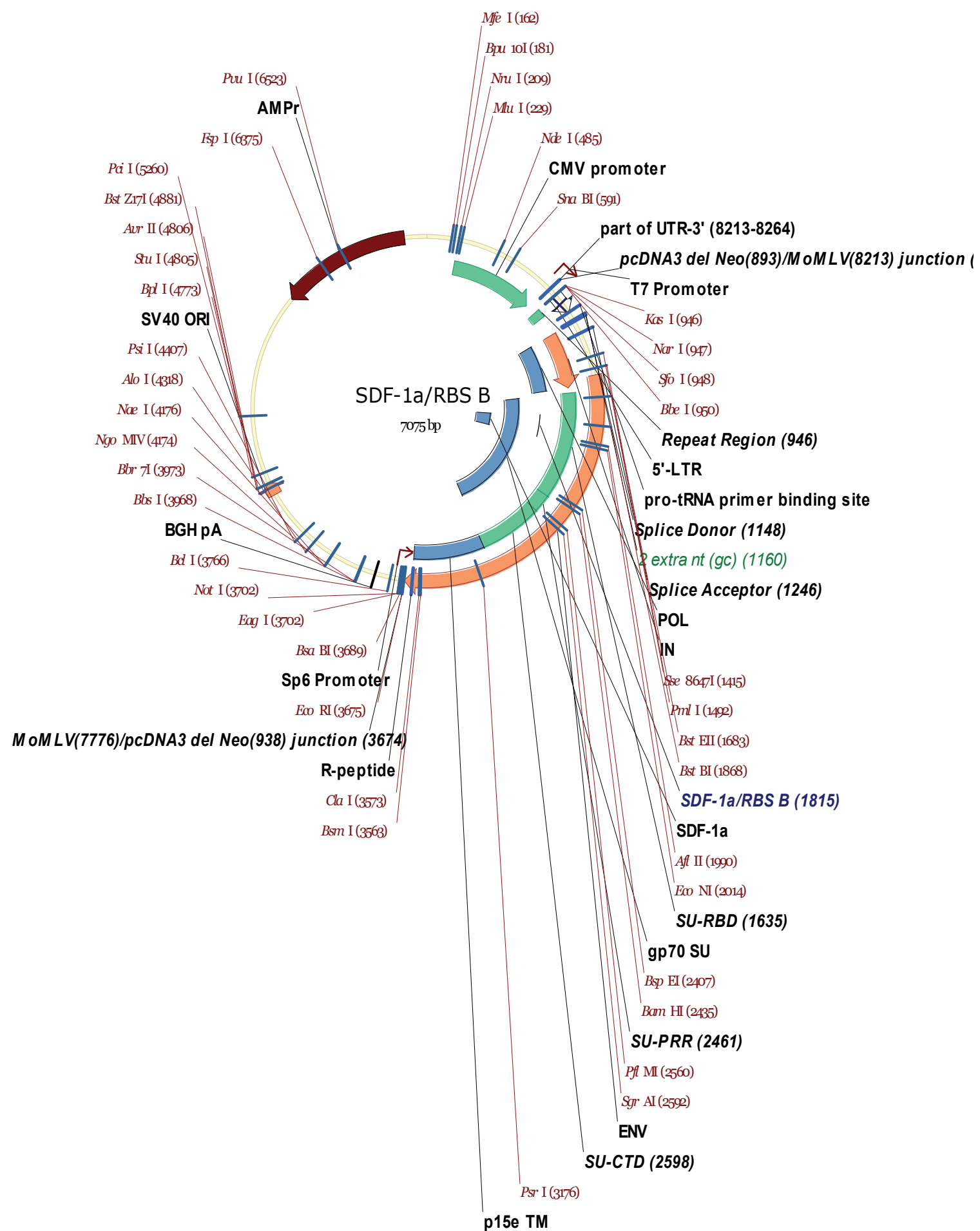

Figure C-15. SDF-1a/RBS B. 


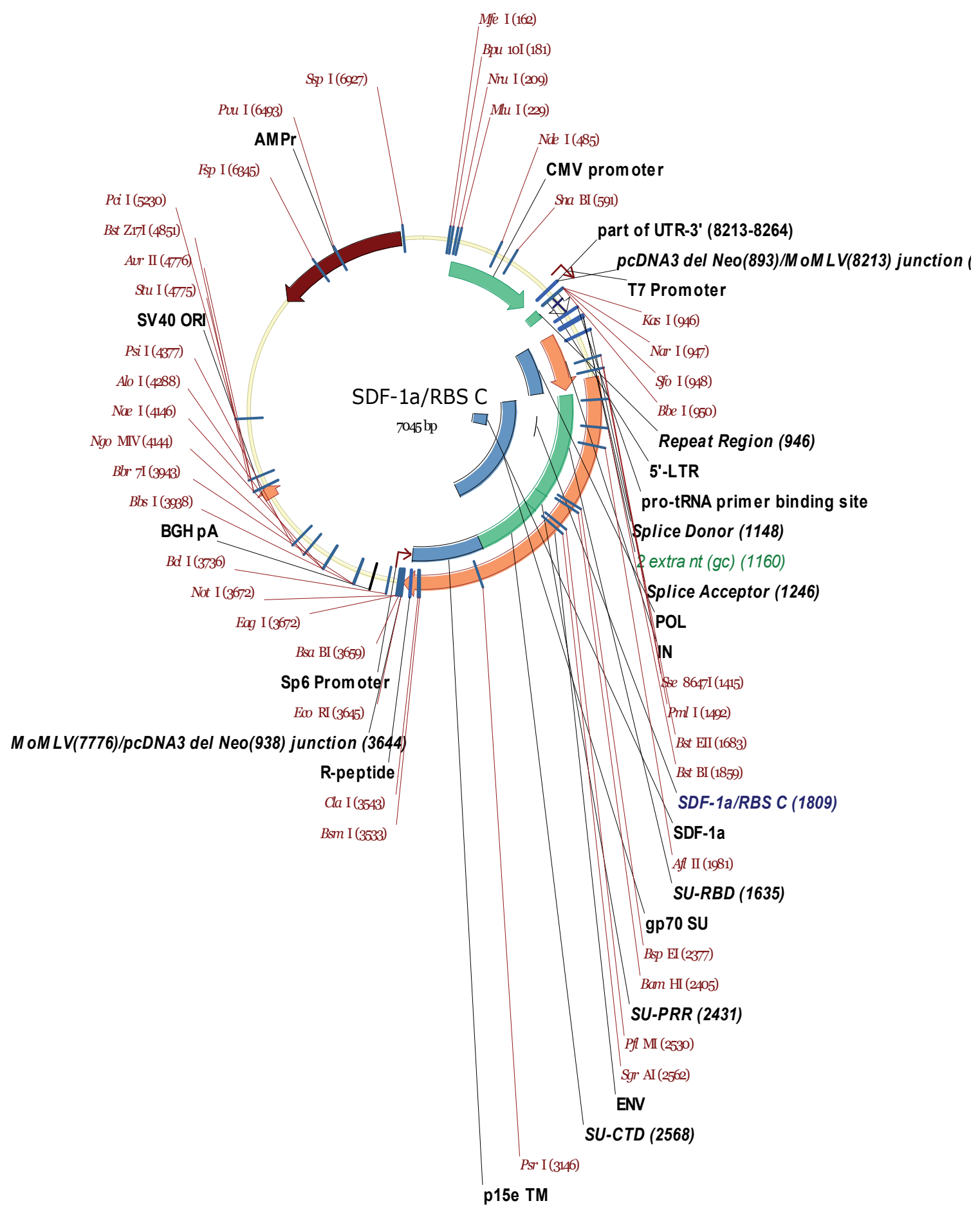

Figure C-16. SDF-1a/RBS C. 


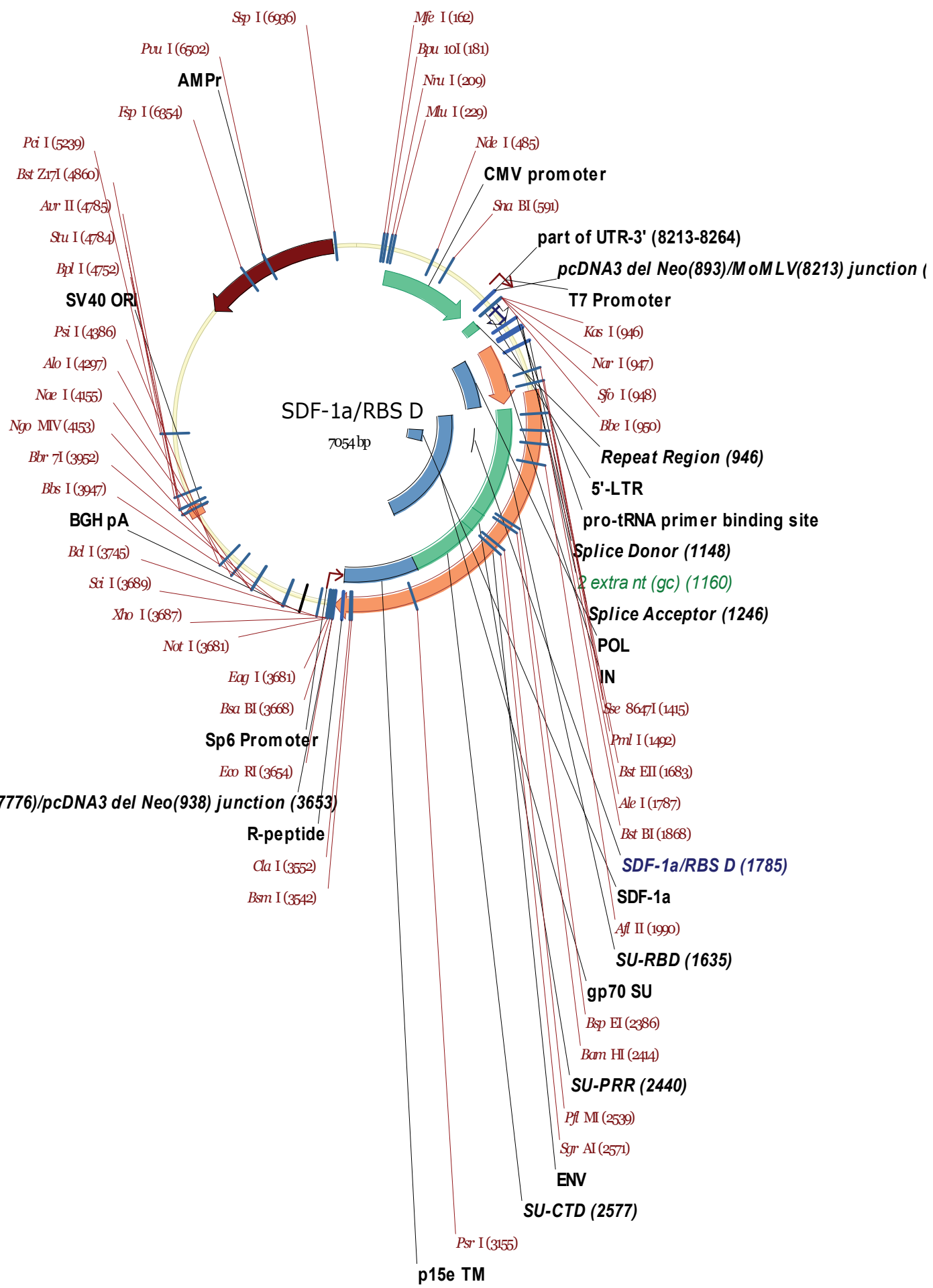

Figure C-17. SDF-1a/RBS D. 


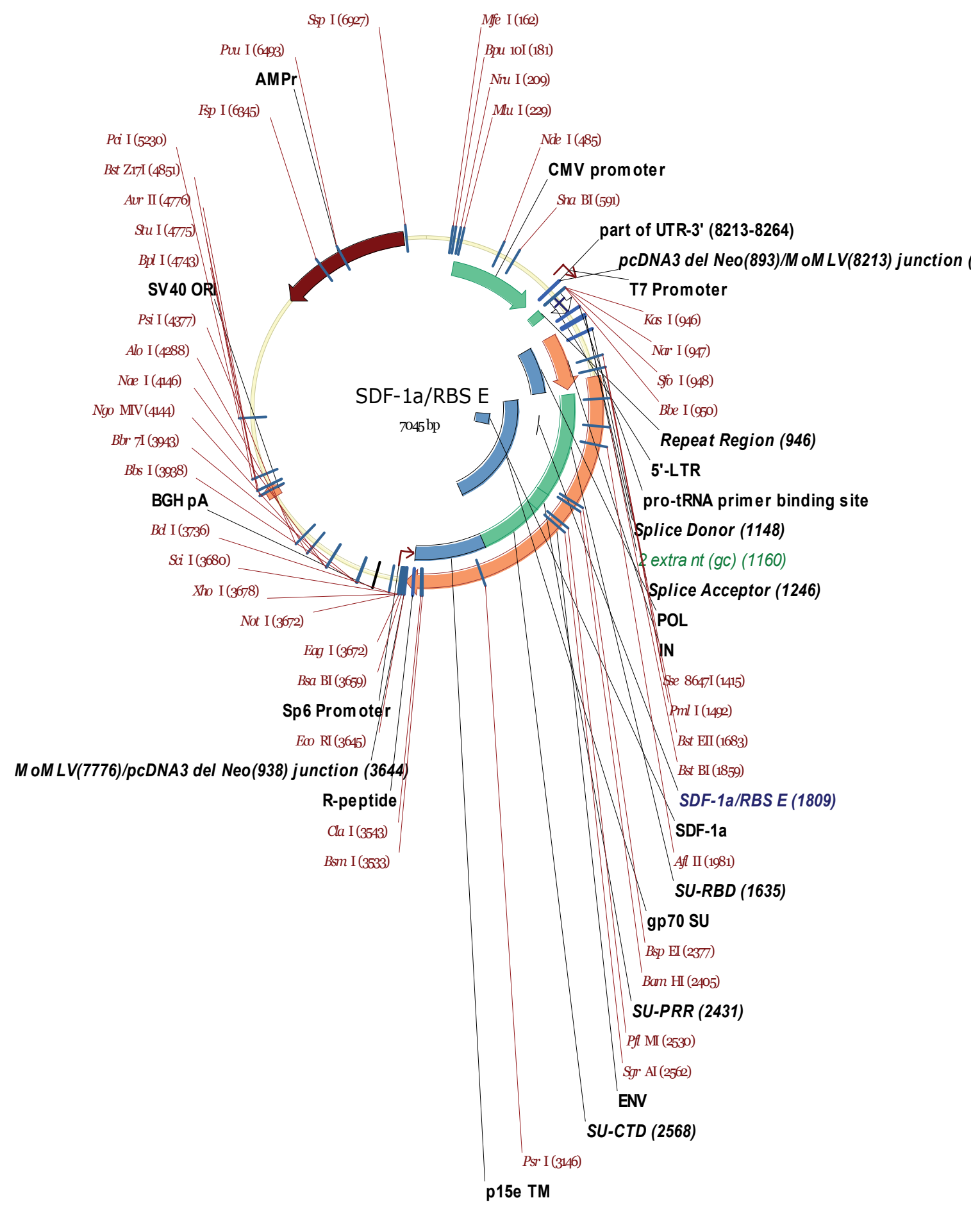

Figure C-18. SDF-1a/RBS E. 


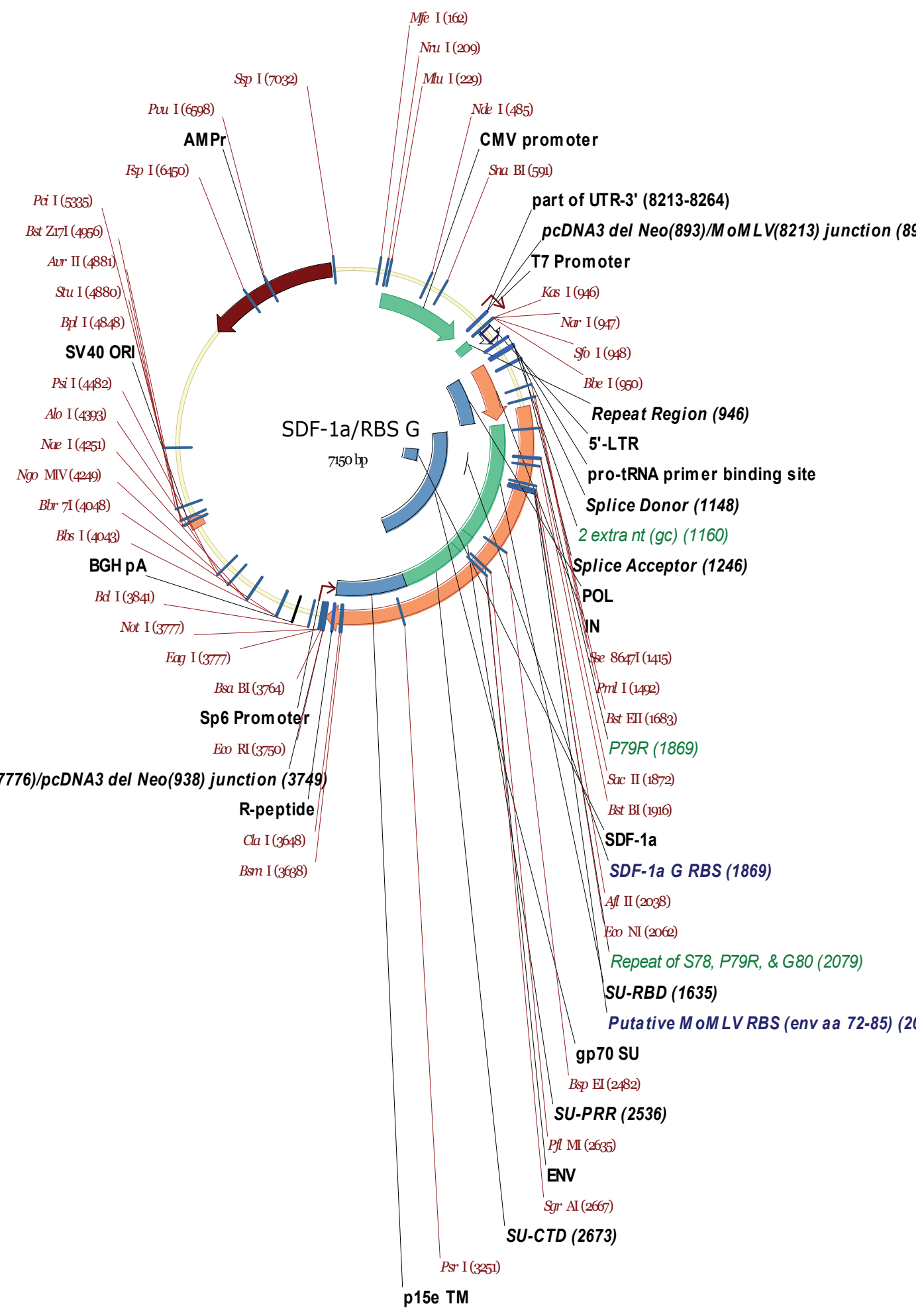

Figure C-19. SDF-1a/RBS G. 


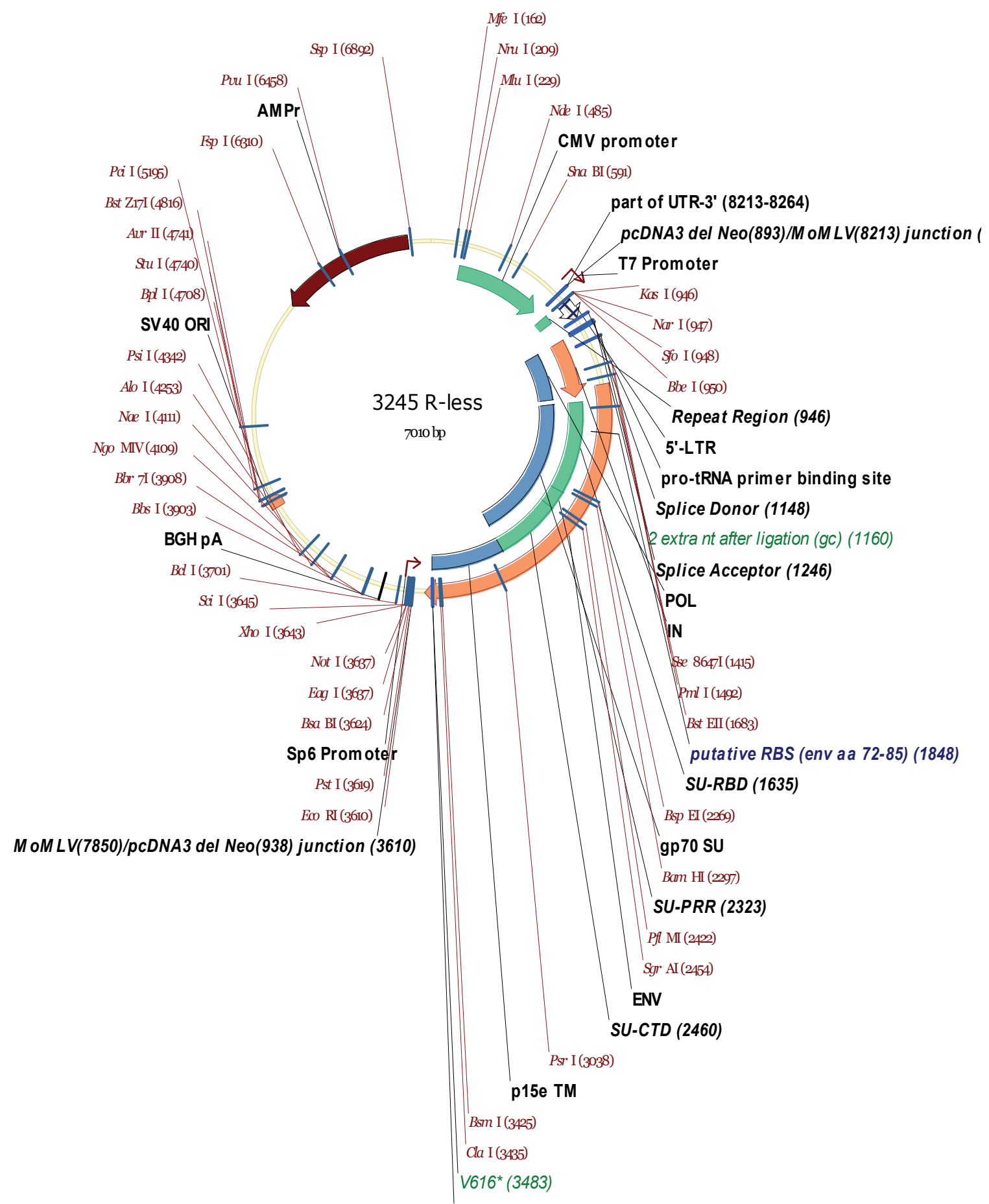

R-peptide

Figure C-20. 3245 R-less (Q123). 


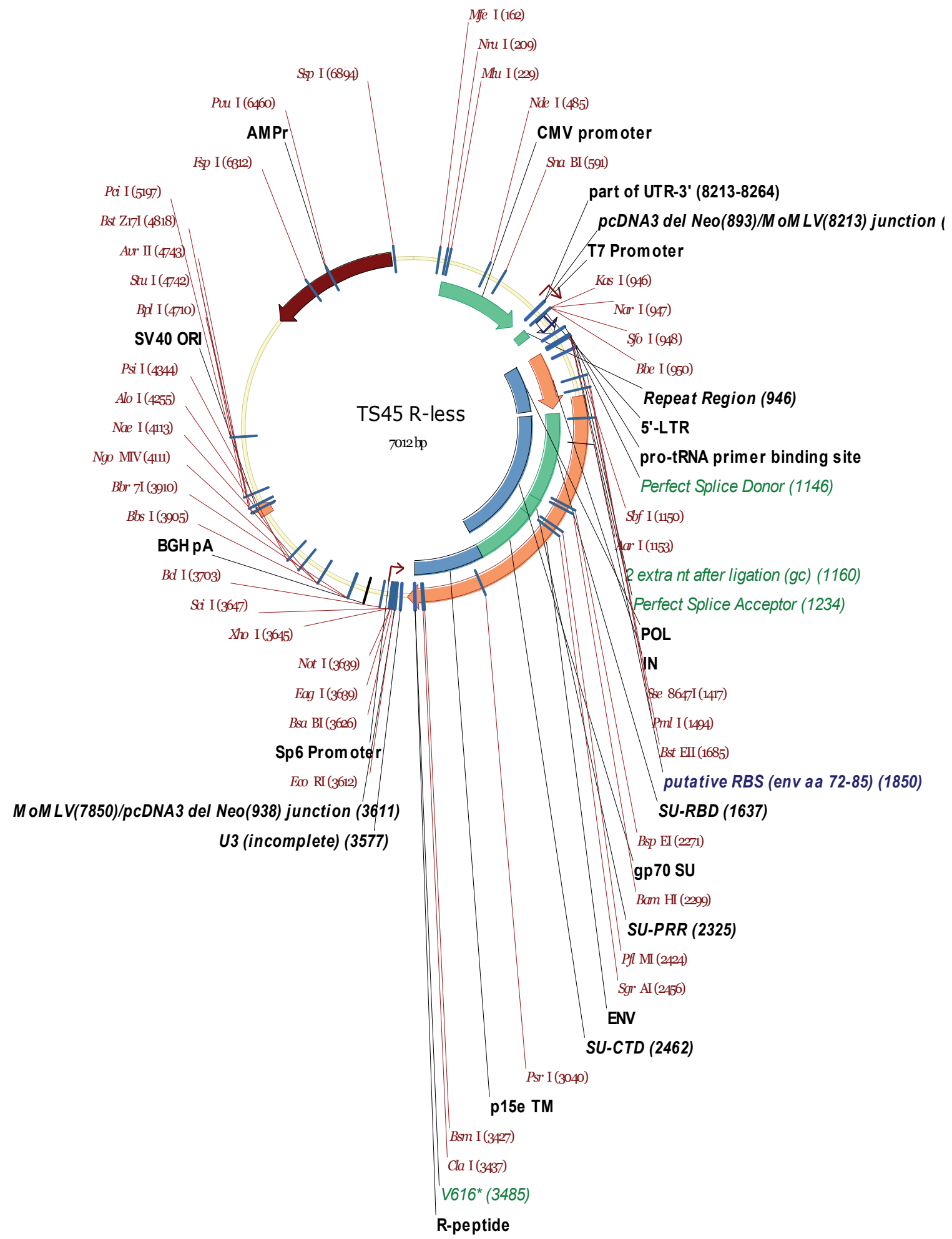

Figure C-21. TS45 R-less. 


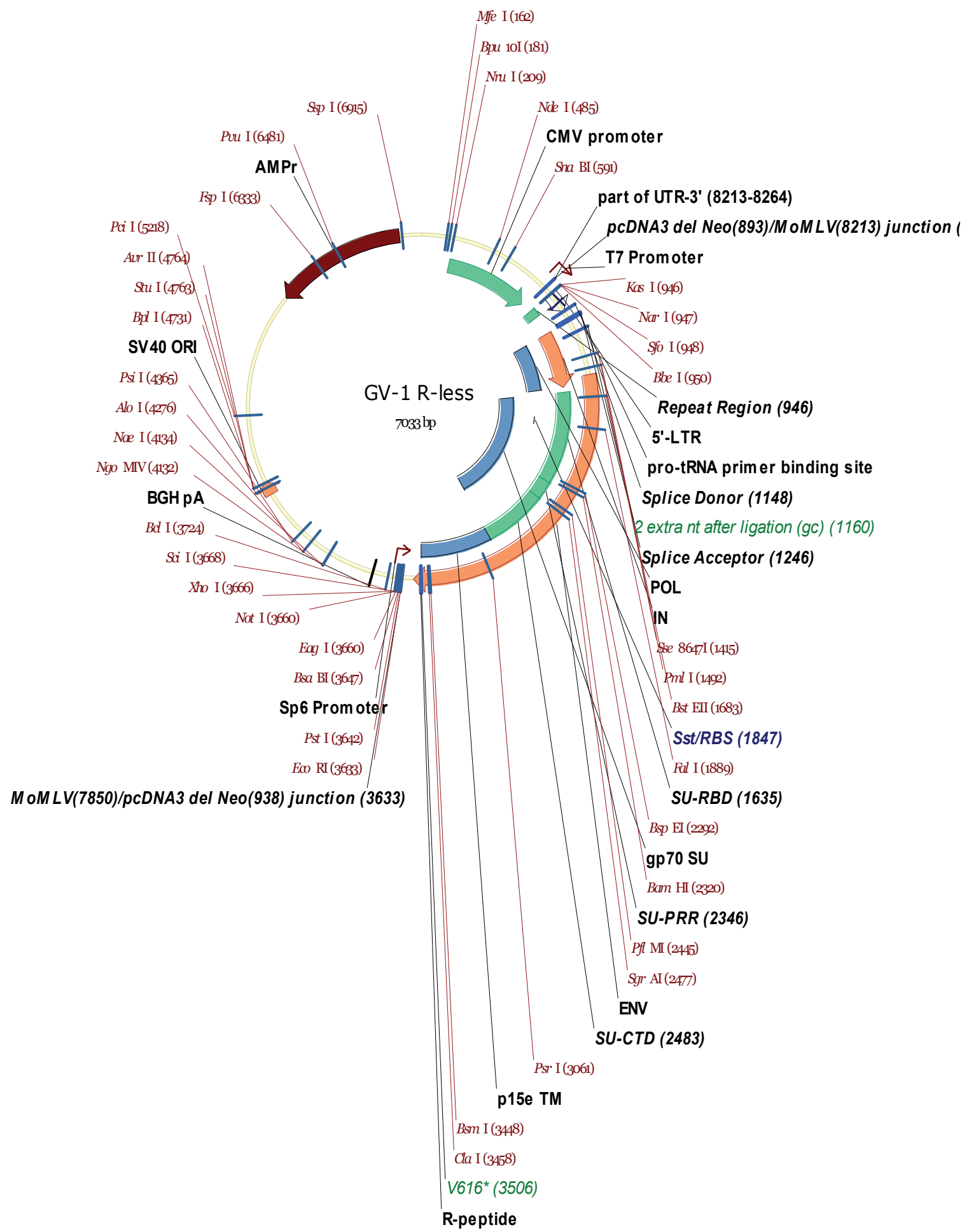

Figure C-22. GV-1 R-less. 


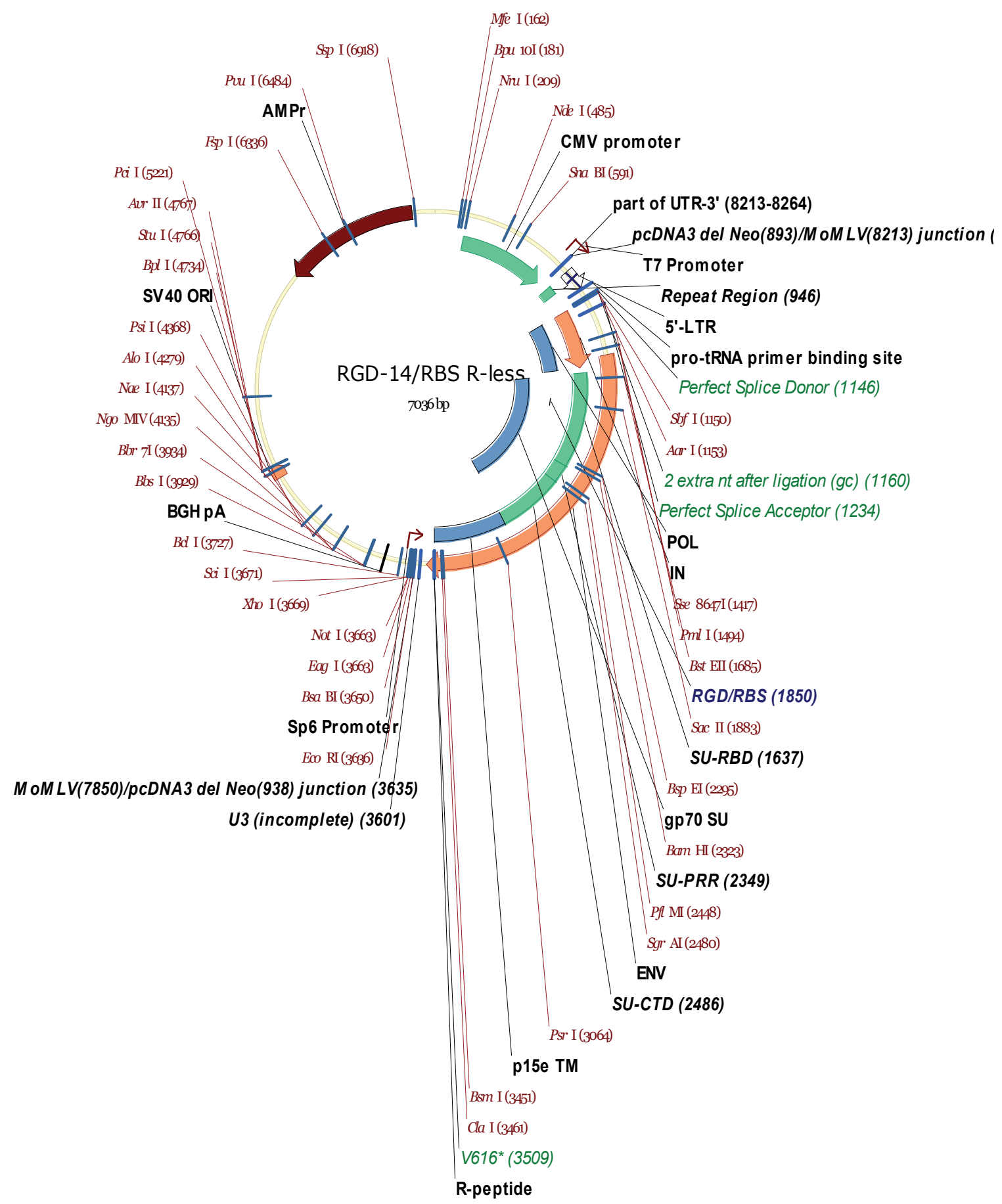

Figure C-23. RGD-14/RBS R-less (45/51A mp2). 


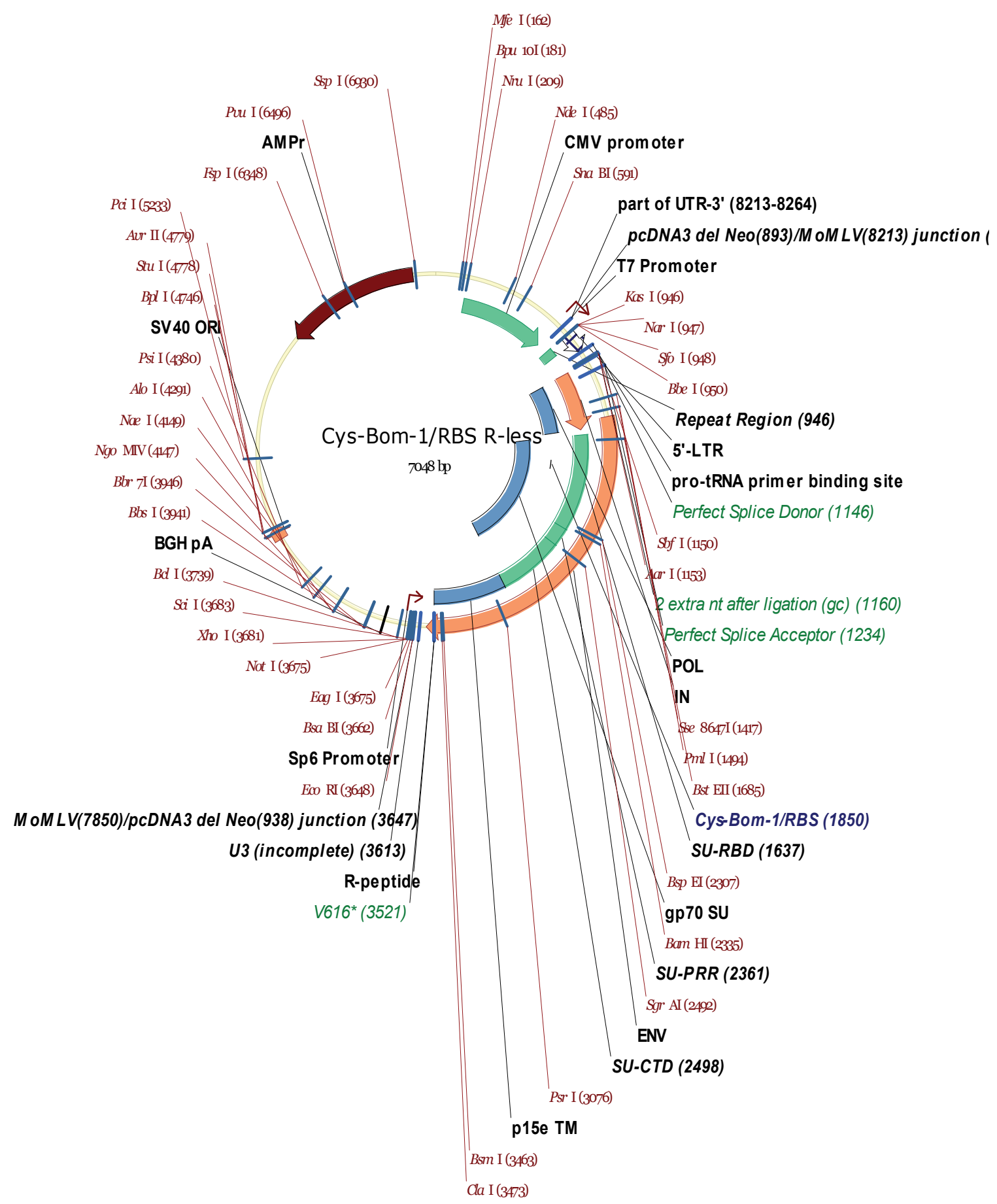

Figure C-24. Cys-Bombesin-1/RBS R-less (45/67 mp2). 


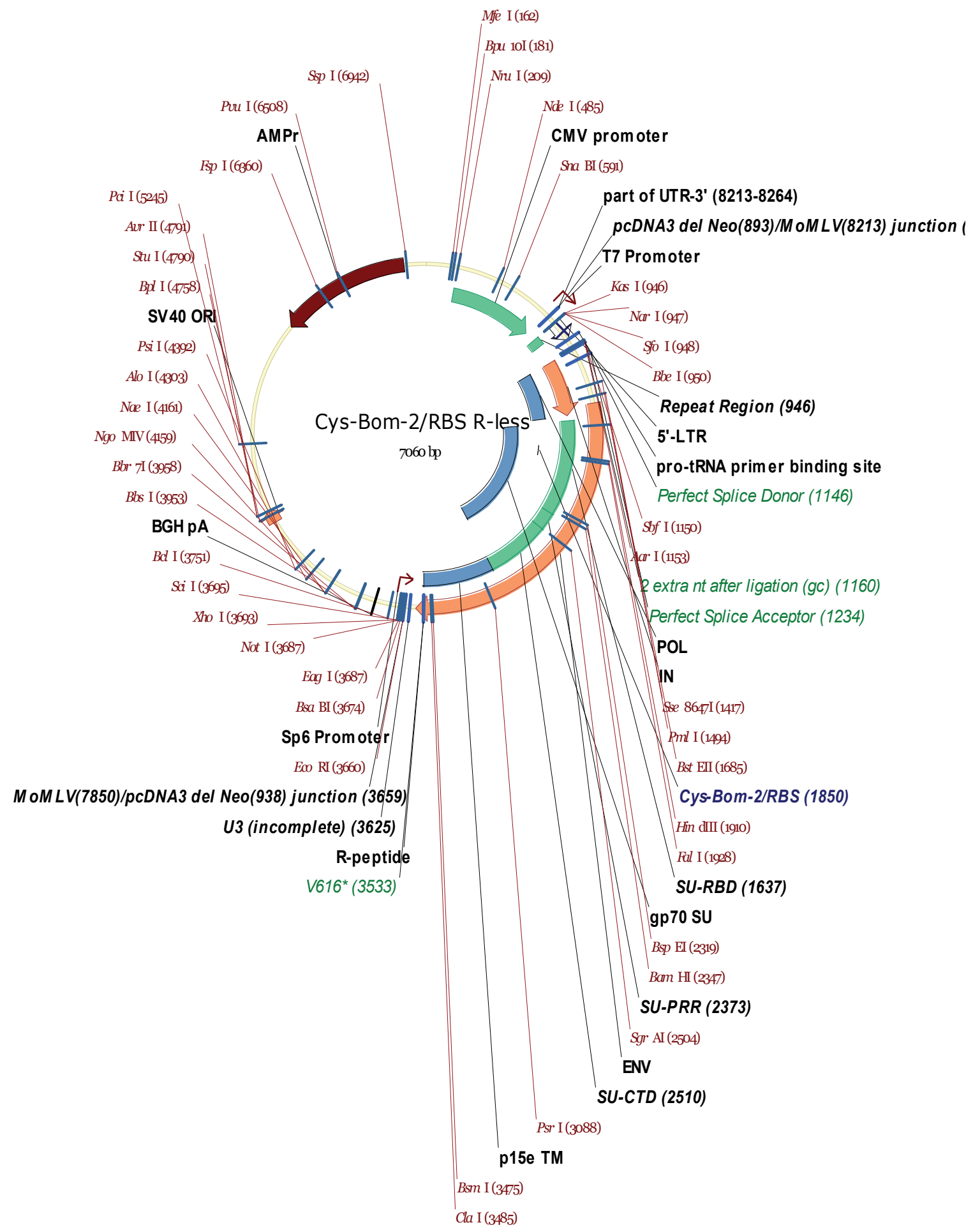

Figure C-25. Cys-Bombesin-2/RBS R-less (45/68 mp2). 


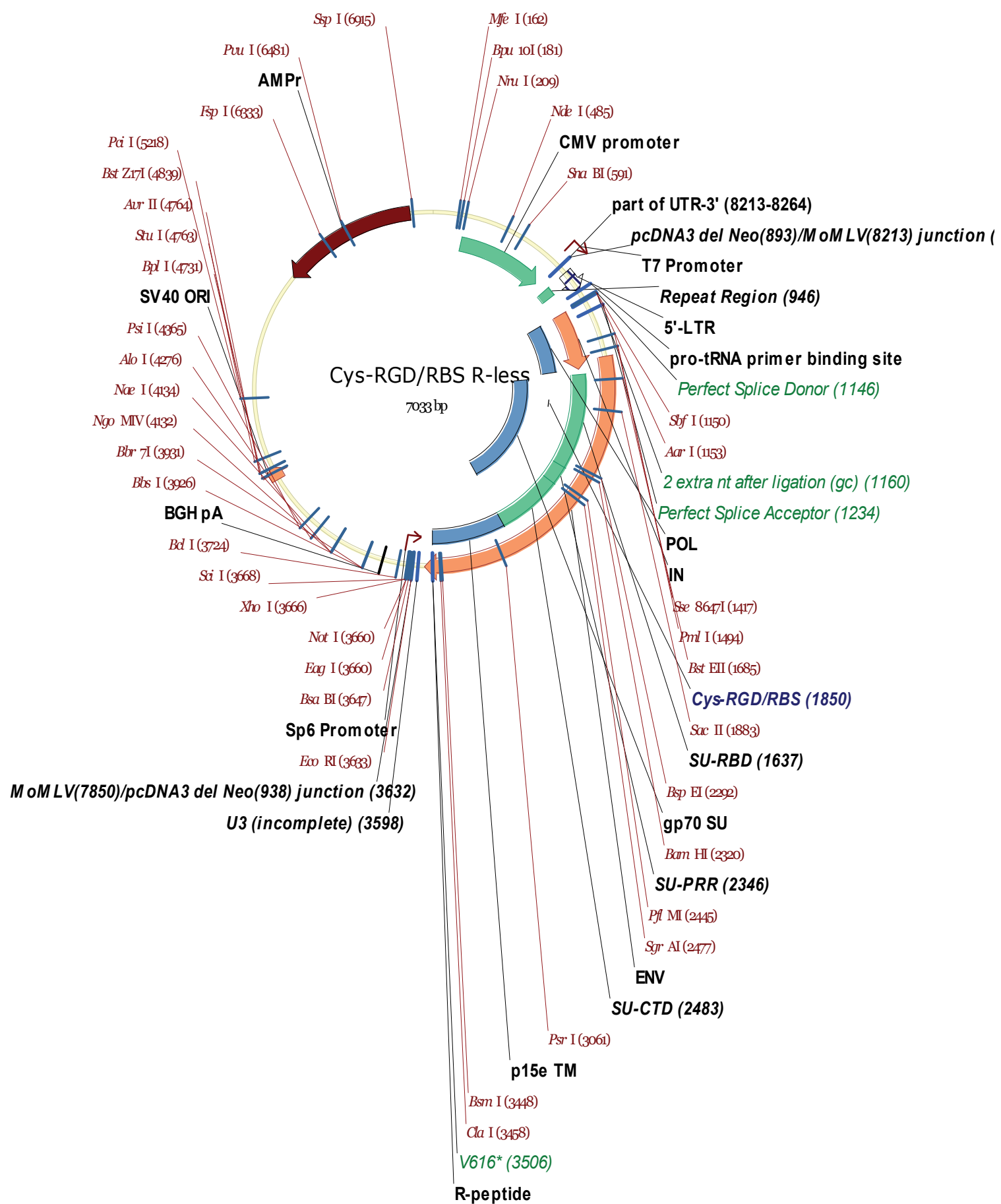

Figure C-26. Cys-RGD-14/RBS R-less (45/59 mp2). 


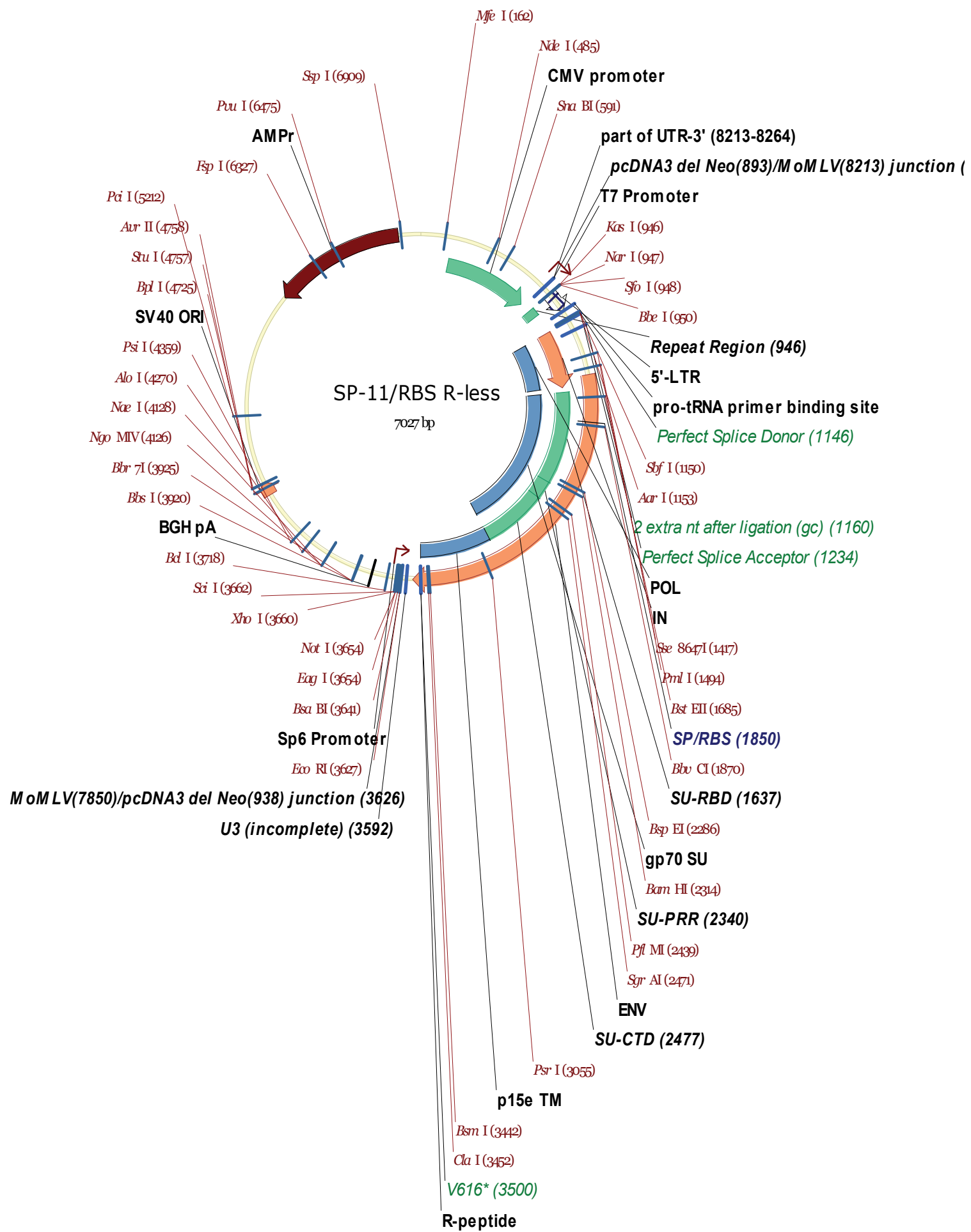

Figure C-27. SP-11/RBS R-less (45/53 mp3). 


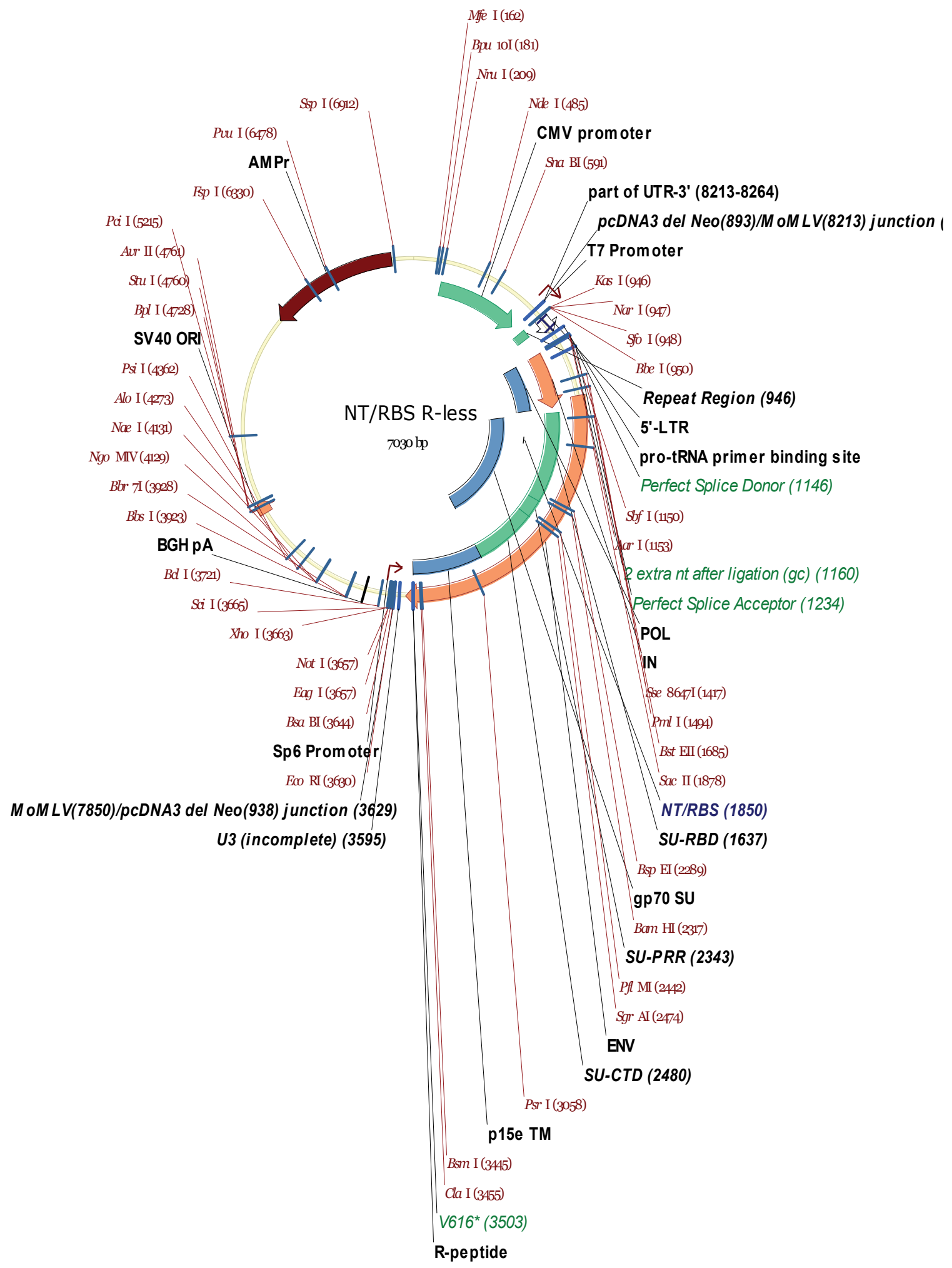

Figure C-28. Neurotensin/RBS R-less (45/54 mp3). 


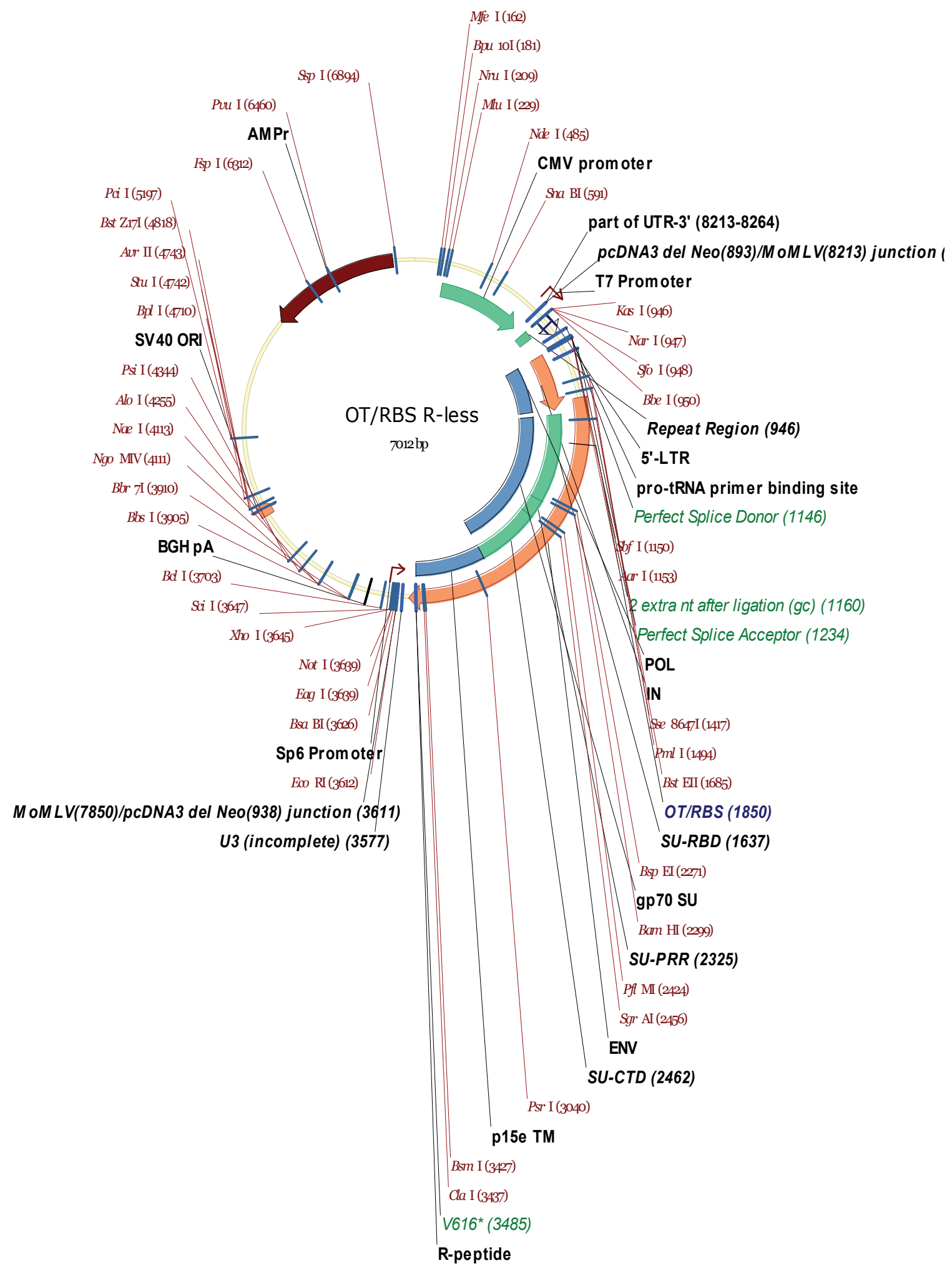

Figure C-29. Oxytocin/RBS R-less (45/49 mp3). 


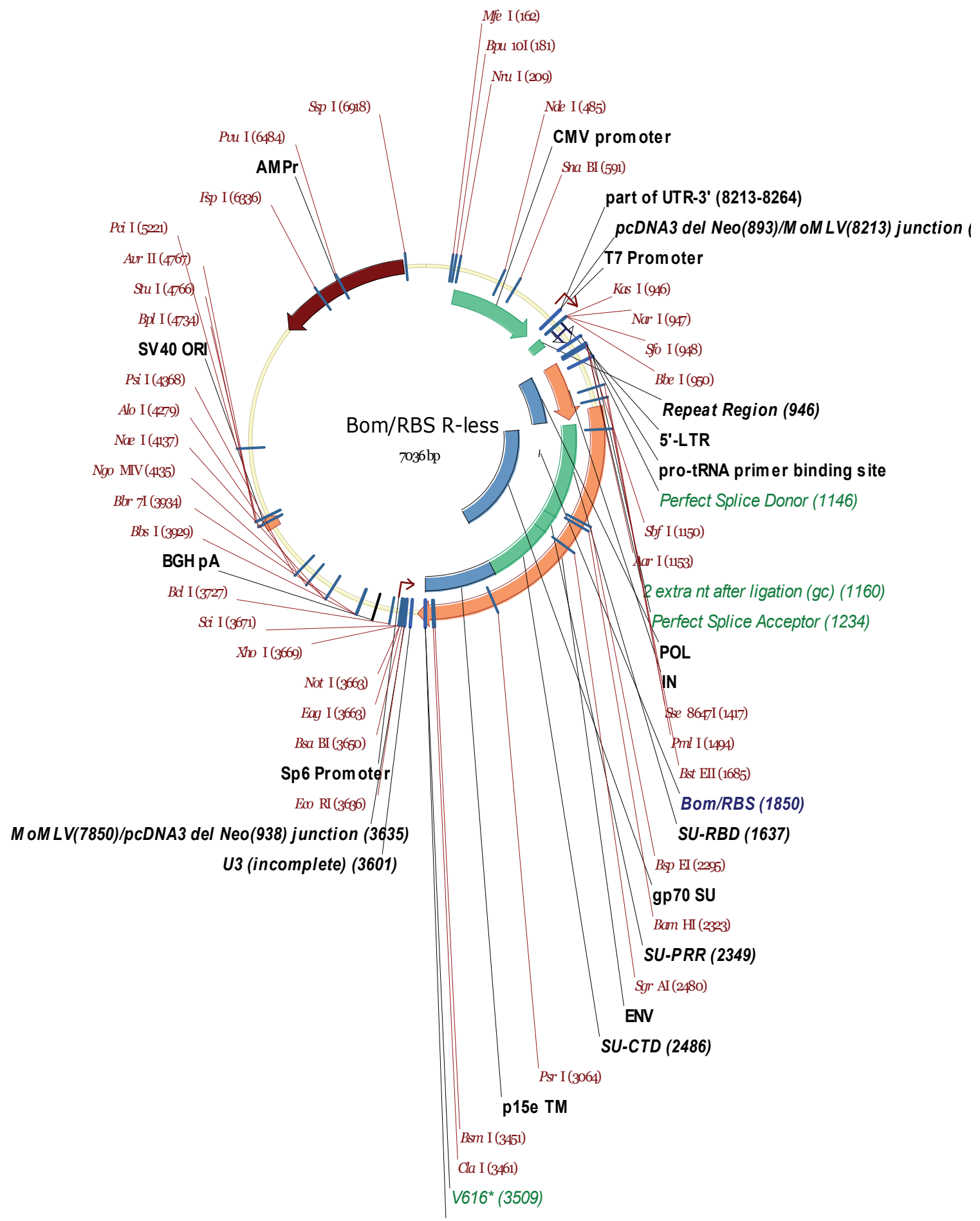

R-peptide

Figure C-30. Bombesin/RBS R-less (45/56-5 mp3). 


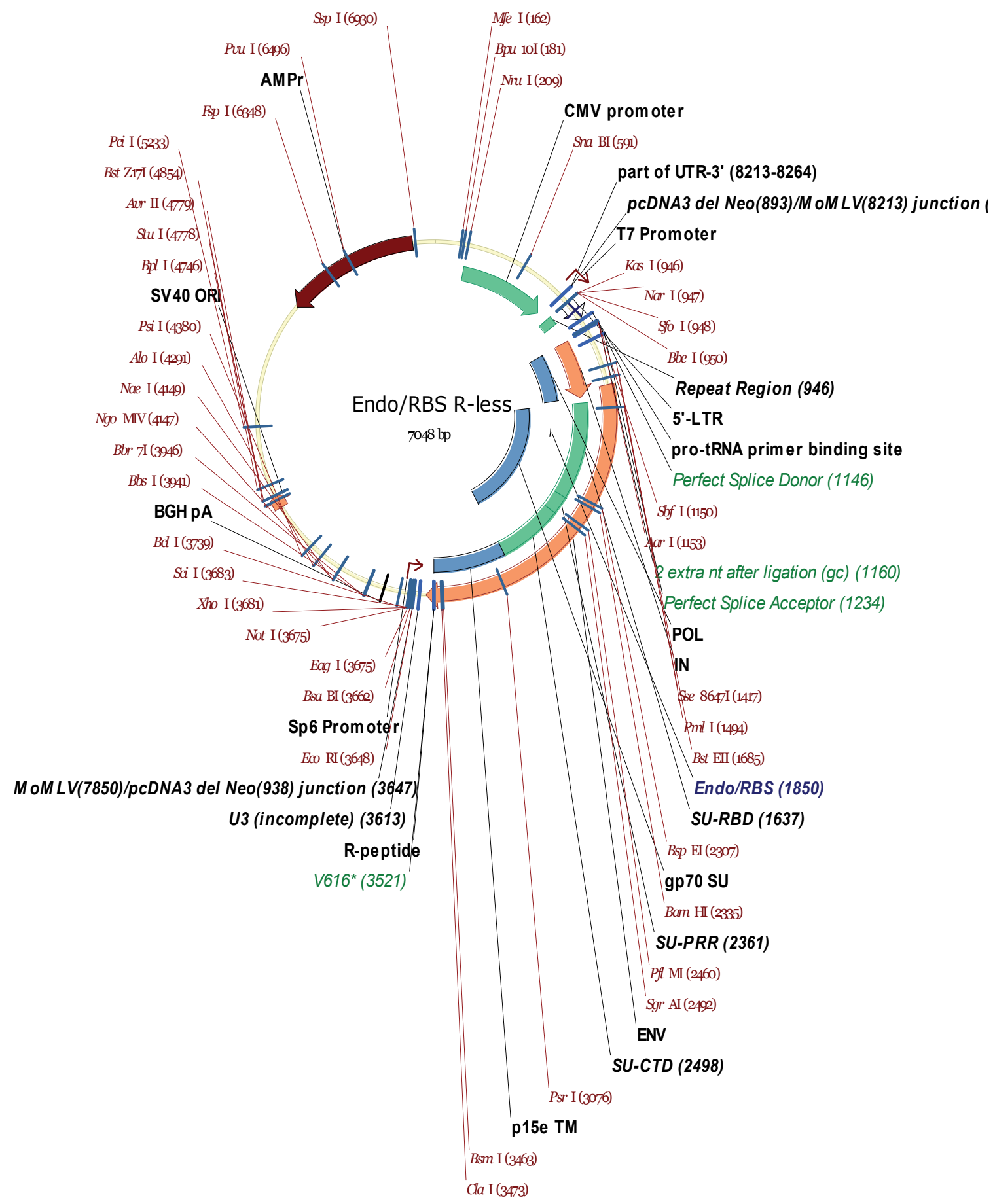

Figure C-31. Endothelin-1/RBS R-less (45/50 mp3). 


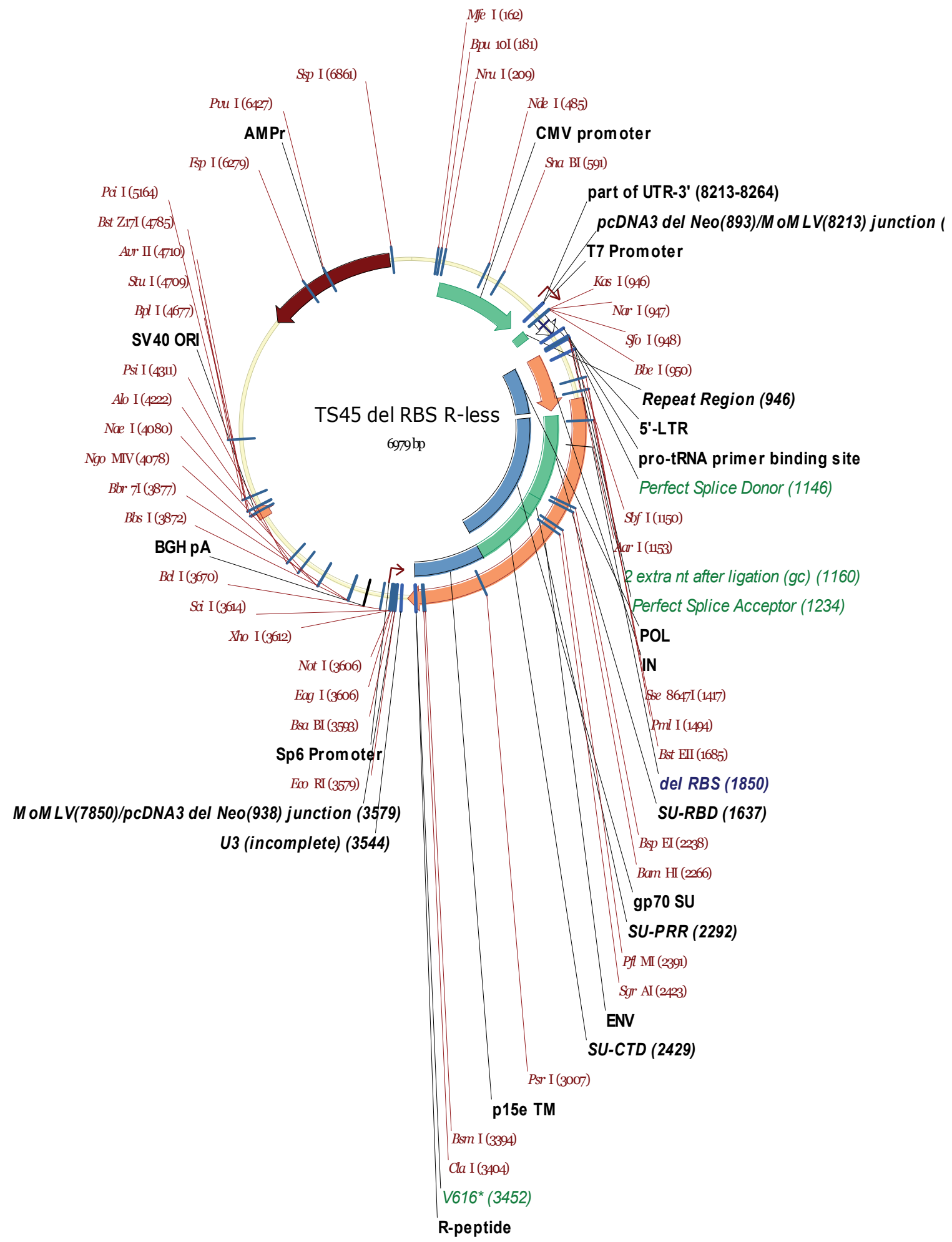

Figure C-32. TS45_delRBS R-less (45/39-4b mp2). 


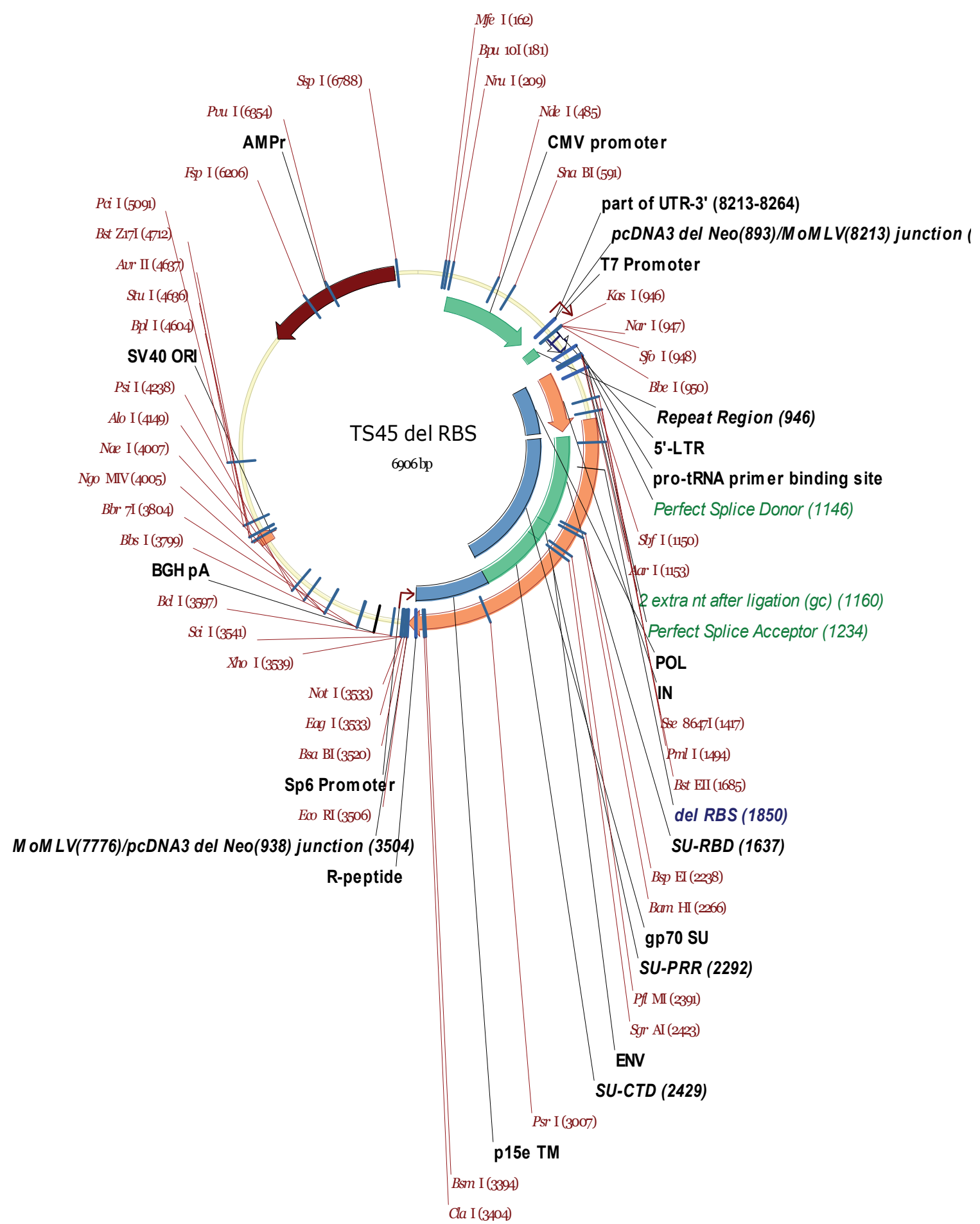

Figure C-33. TS45_delRBS. 


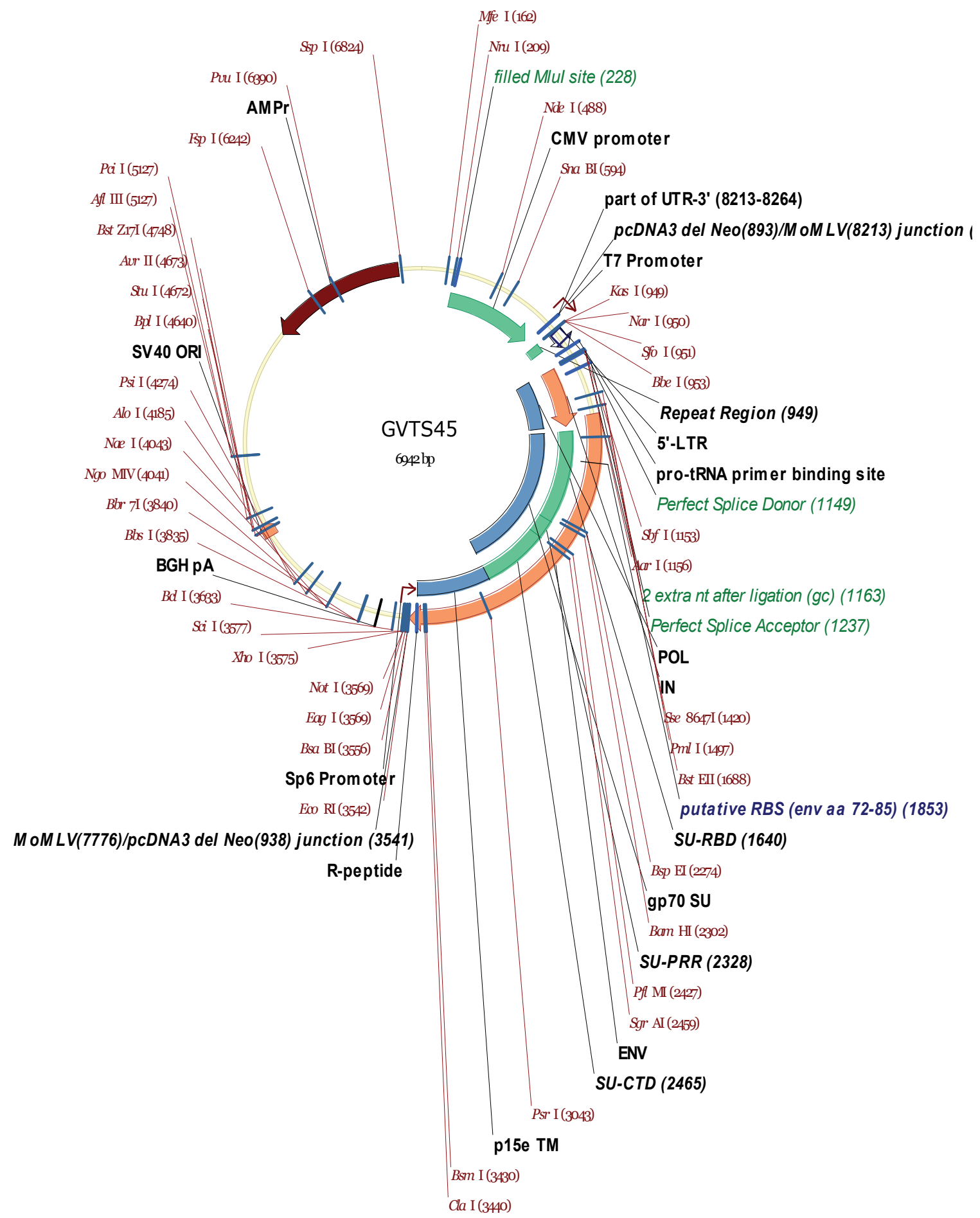

Figure C-34. GVTS45. 


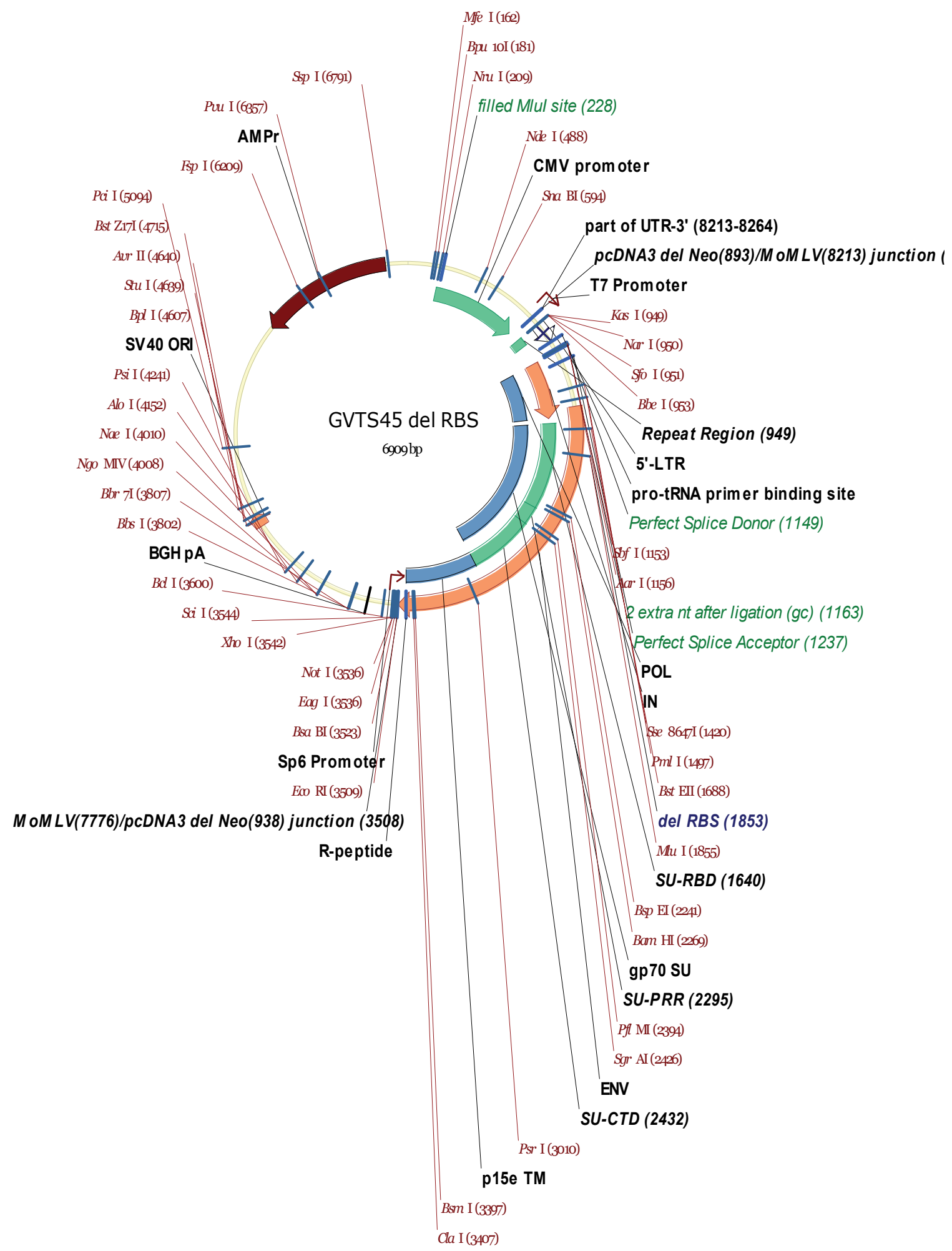

Figure C-35. GVTS45_deIRBS. 


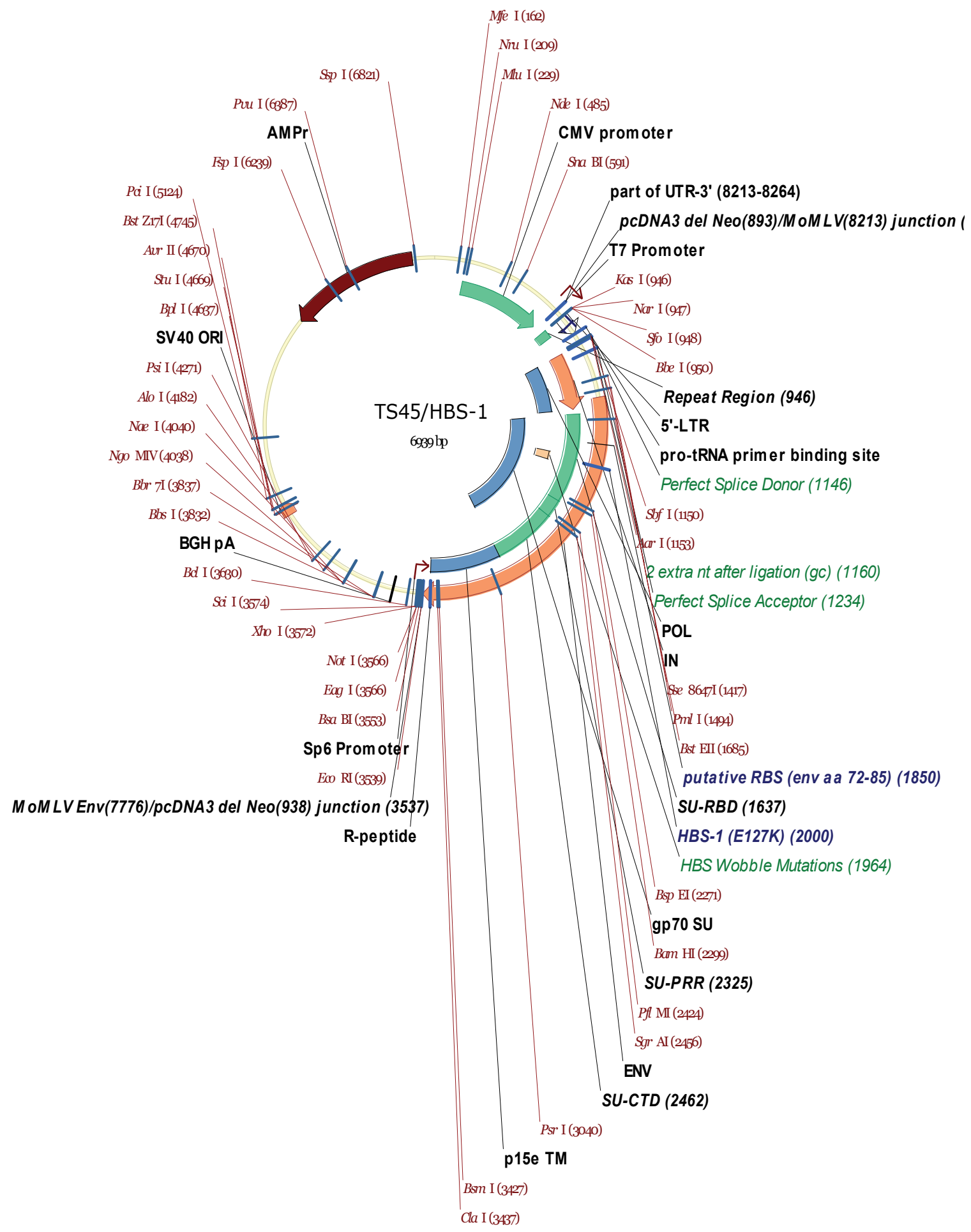

Figure C-36. TS45/HBS-1. 


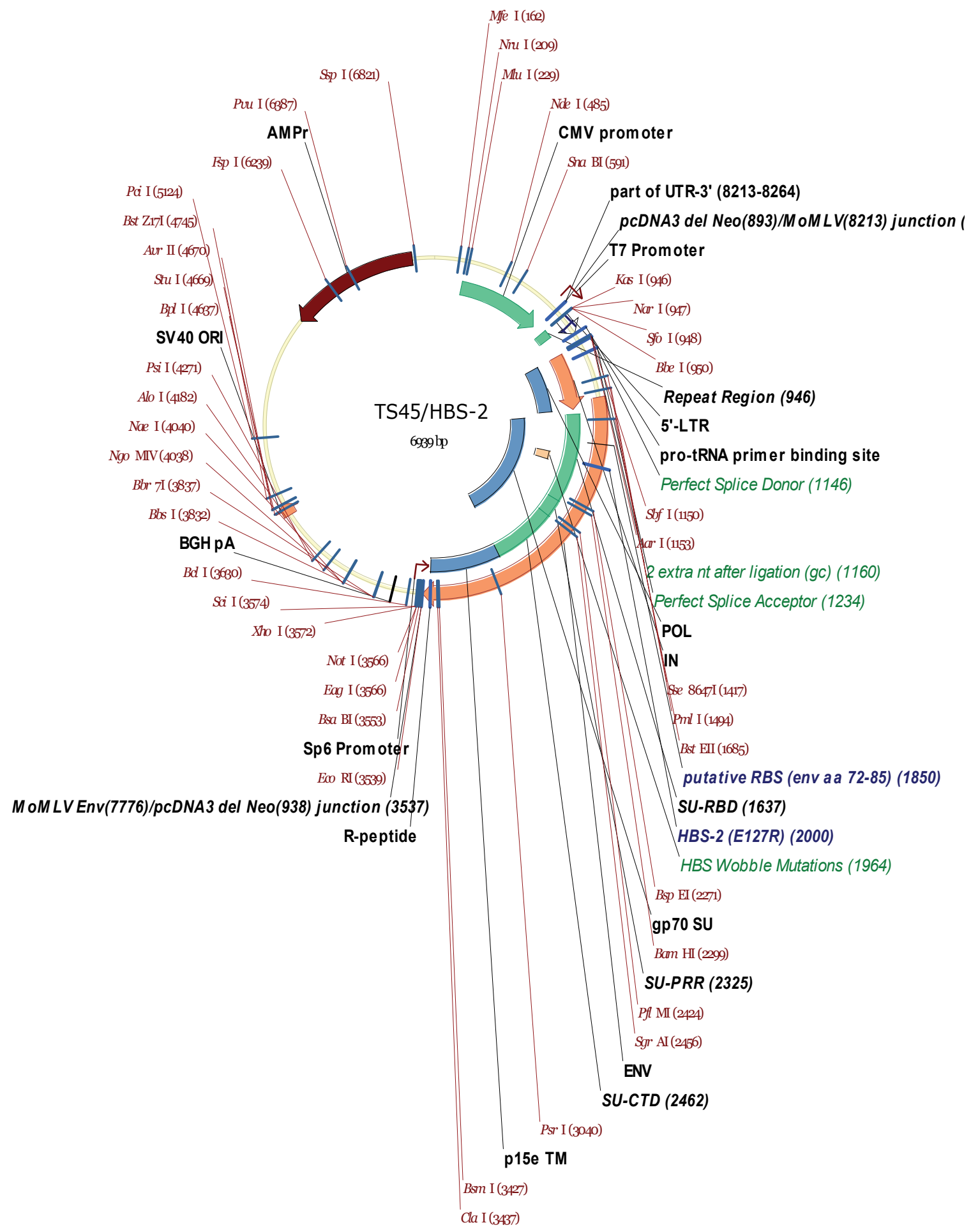

Figure C-37. TS45/HBS-2. 


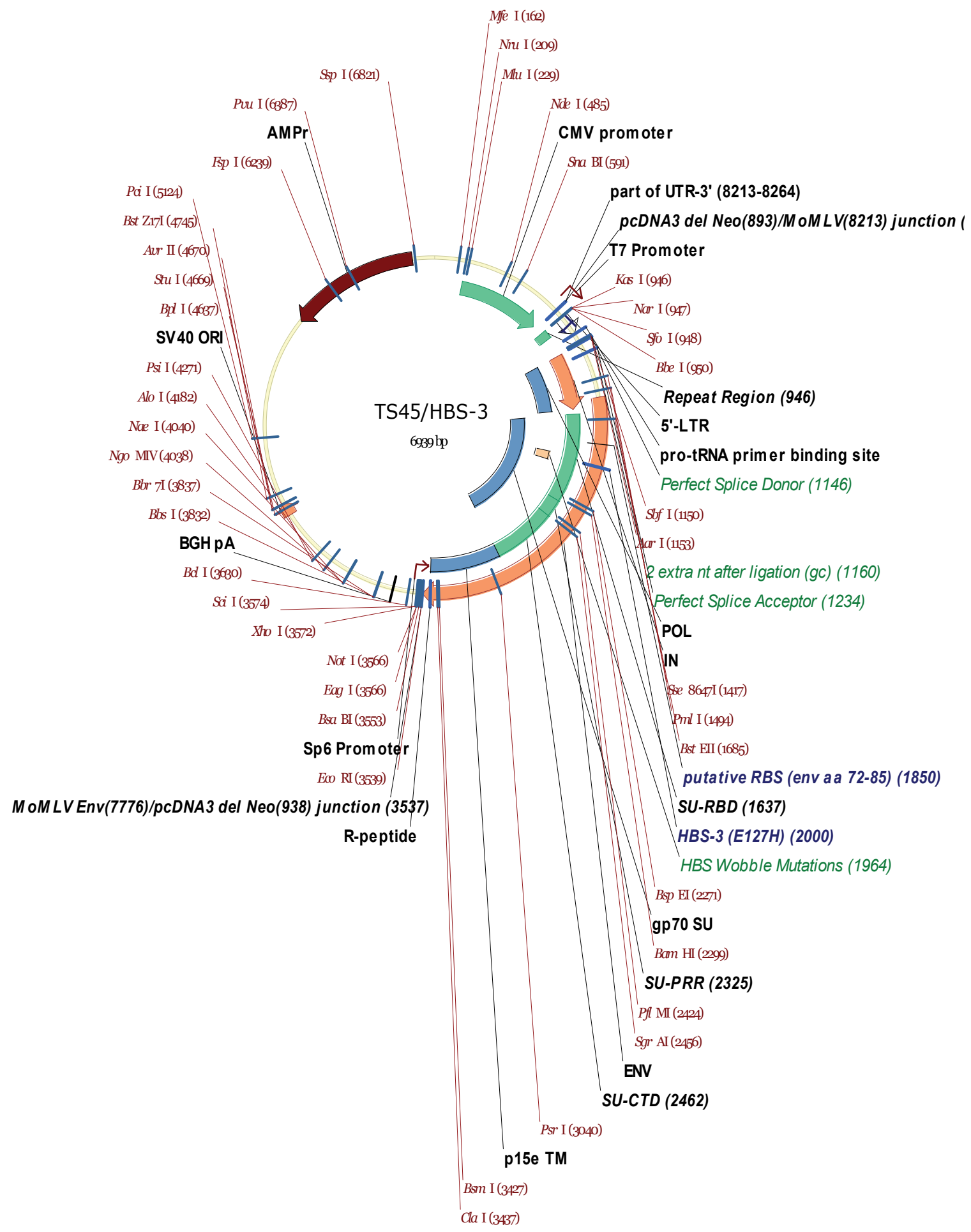

Figure C-38. TS45/HBS-3. 


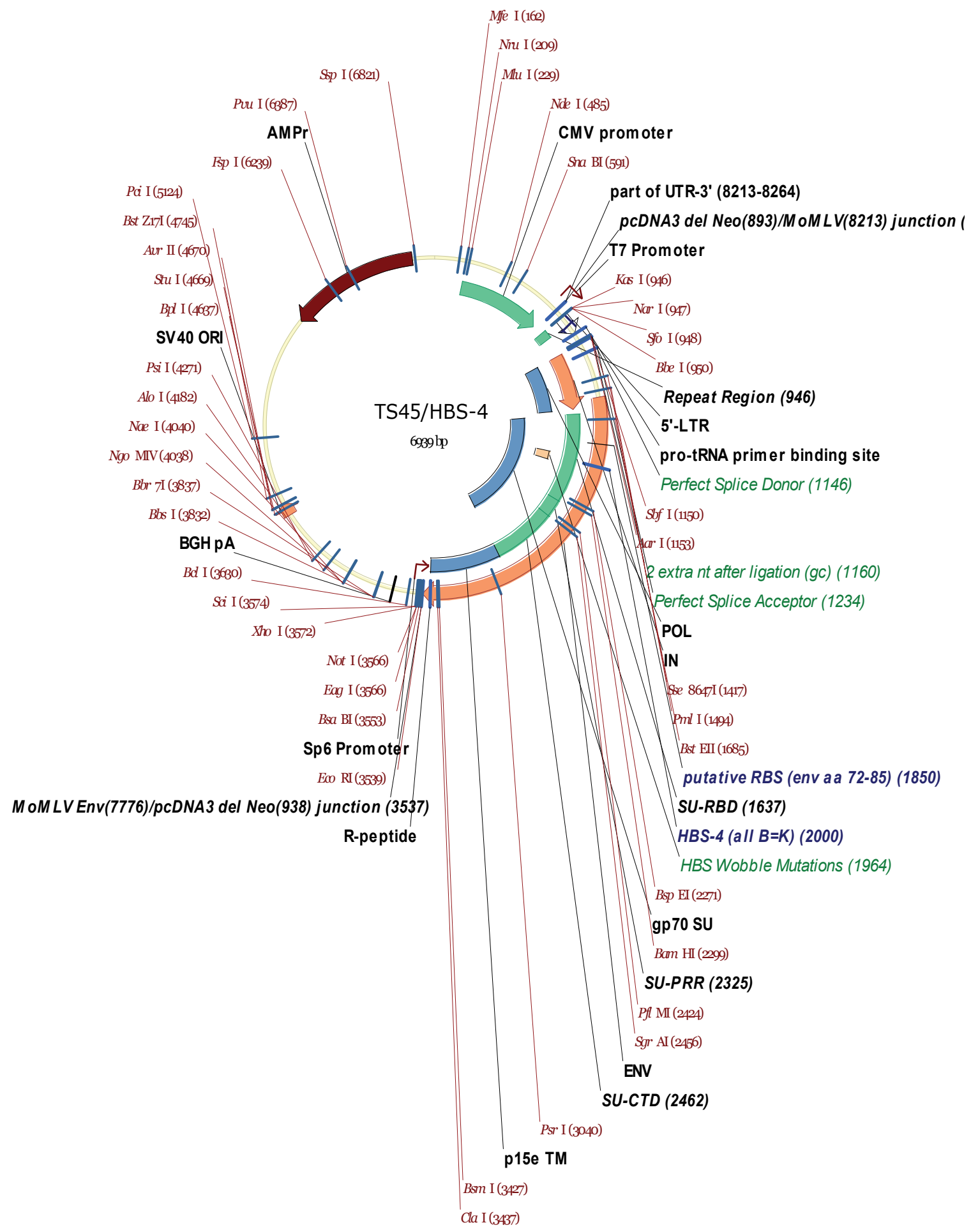

Figure C-39. TS45/HBS-4. 


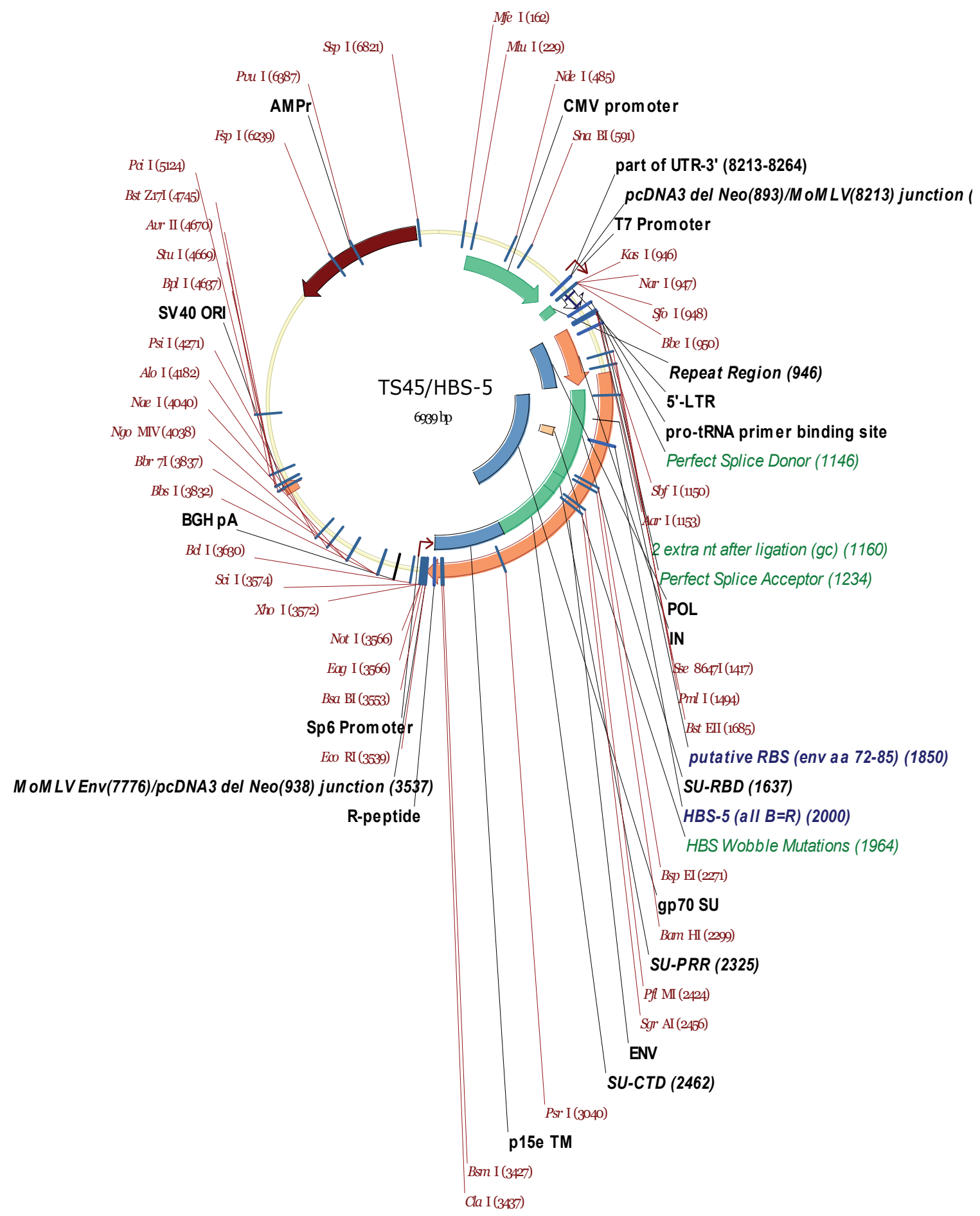

Figure C-40. TS45/HBS-5. 


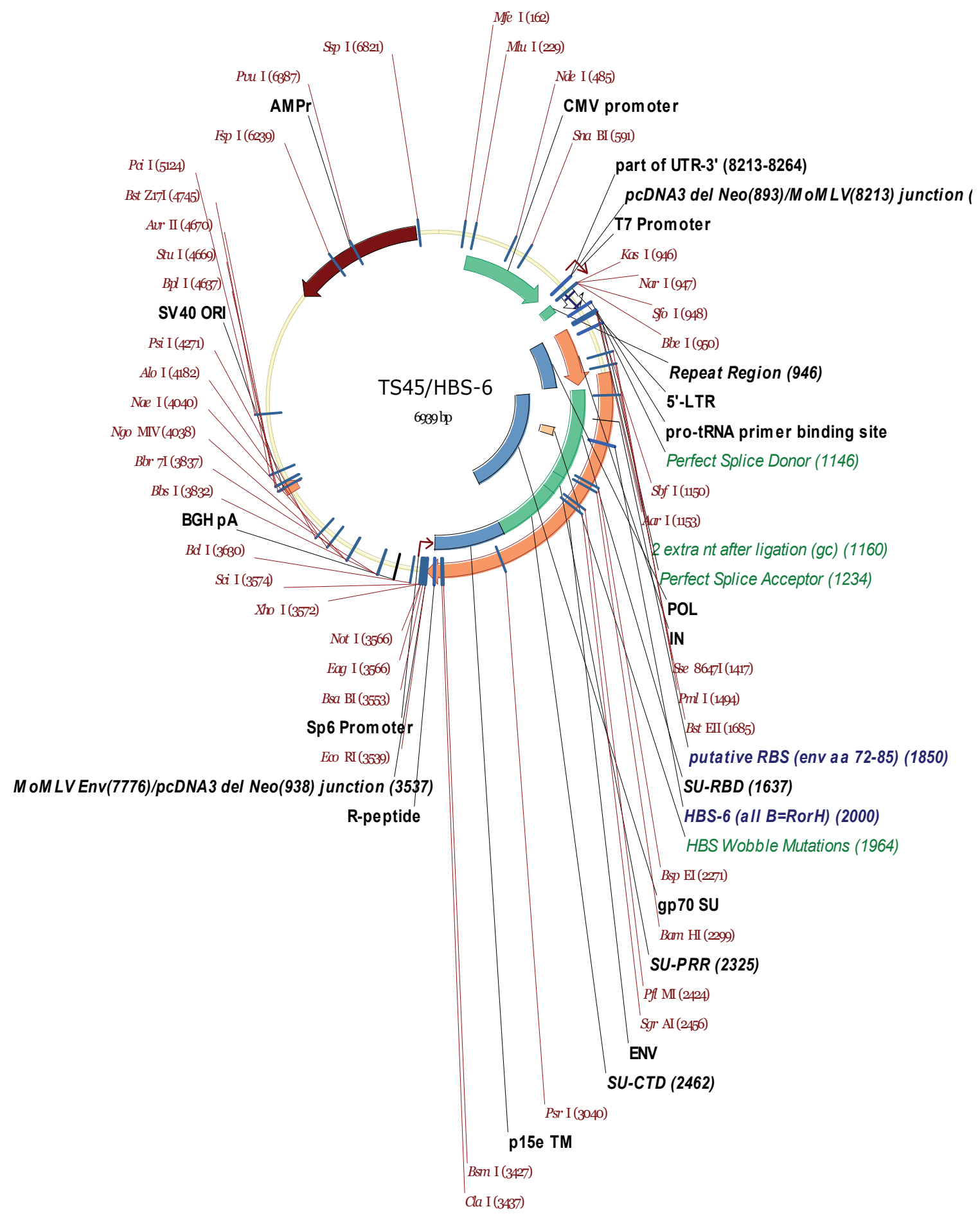

Figure C-41. TS45/HBS-6. 


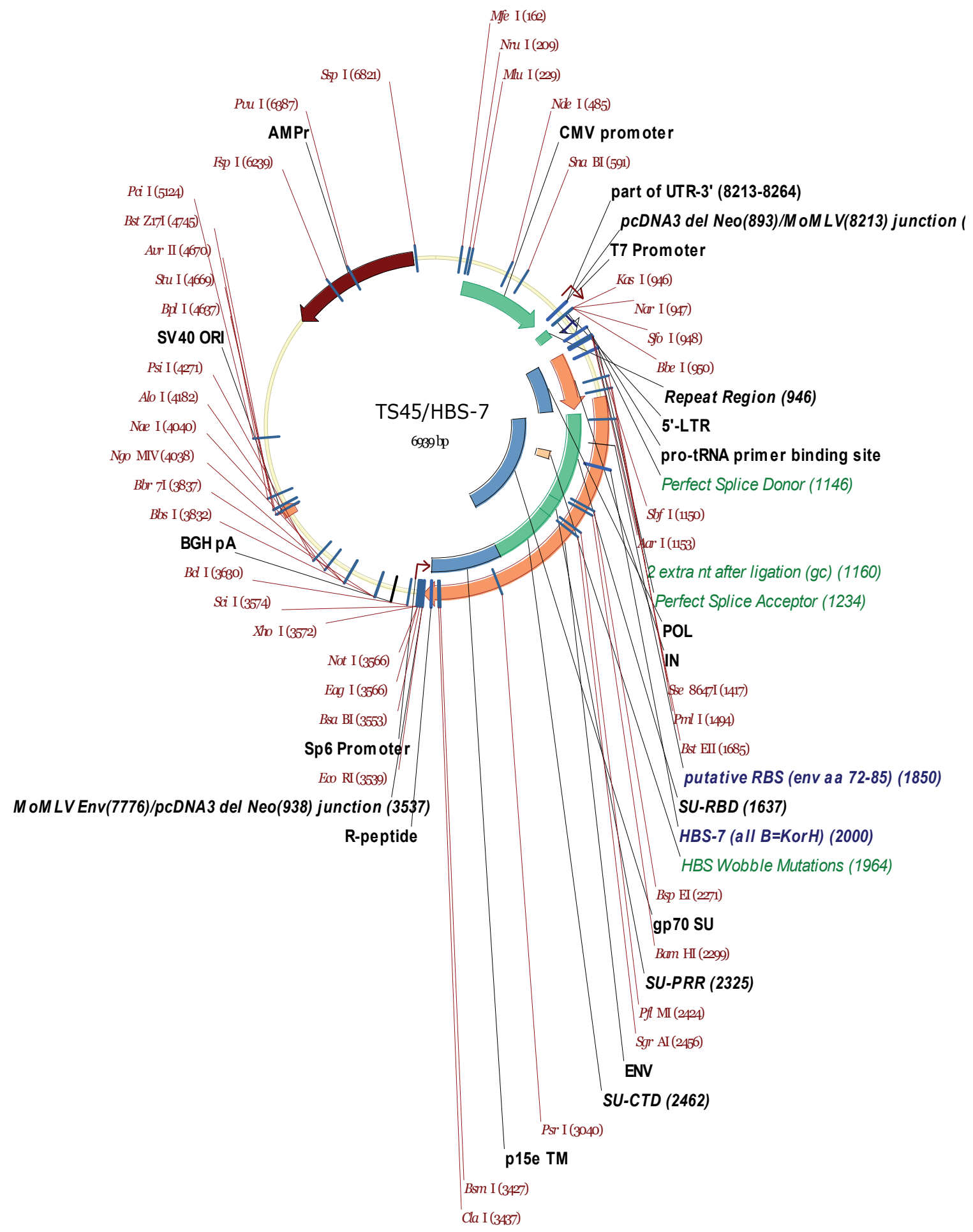

Figure C-42. TS45/HBS-7. 


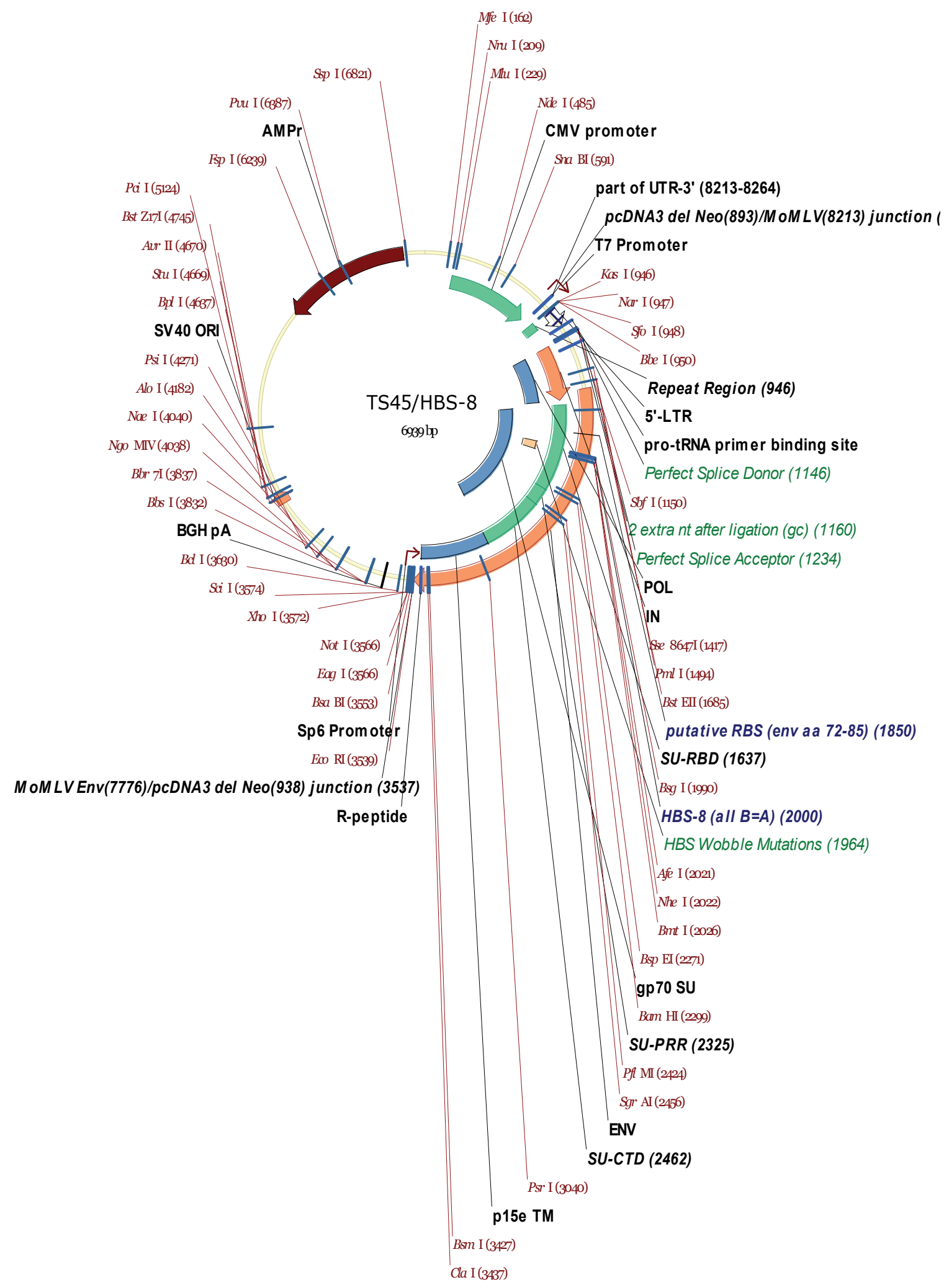

Figure C-43. TS45/HBS-8. 


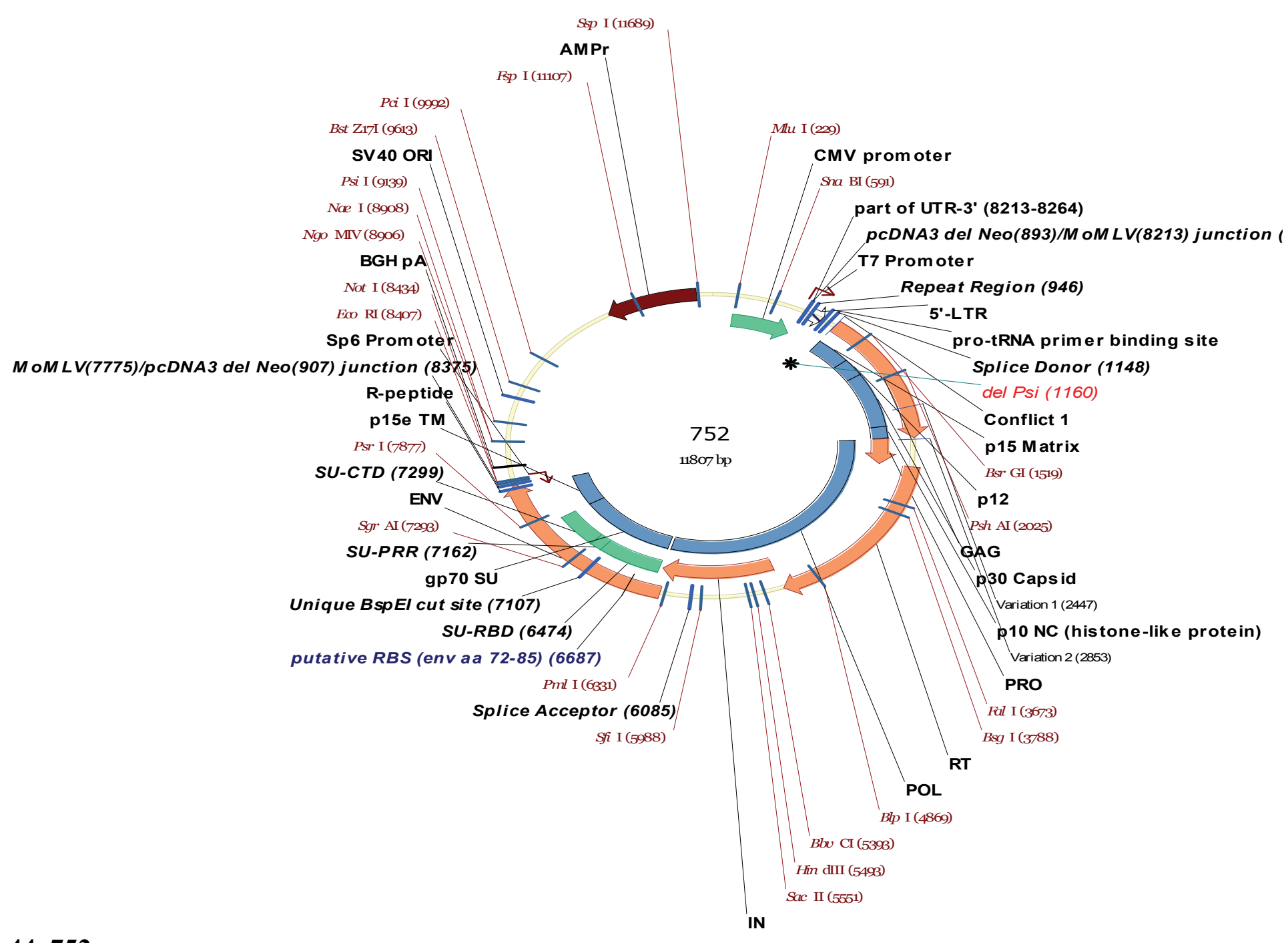

Figure C-44. 752. 


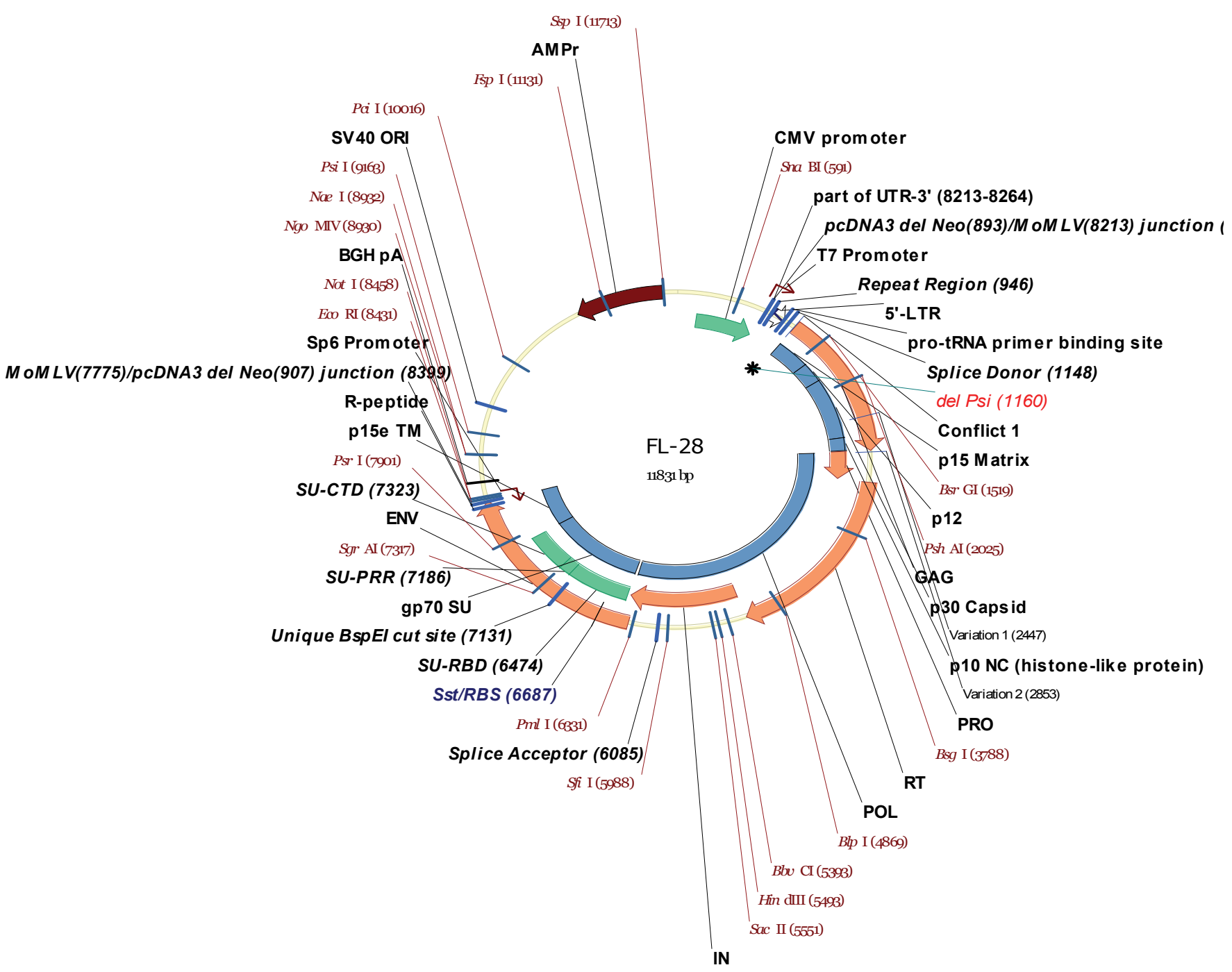

Figure C-45. FL-28. 


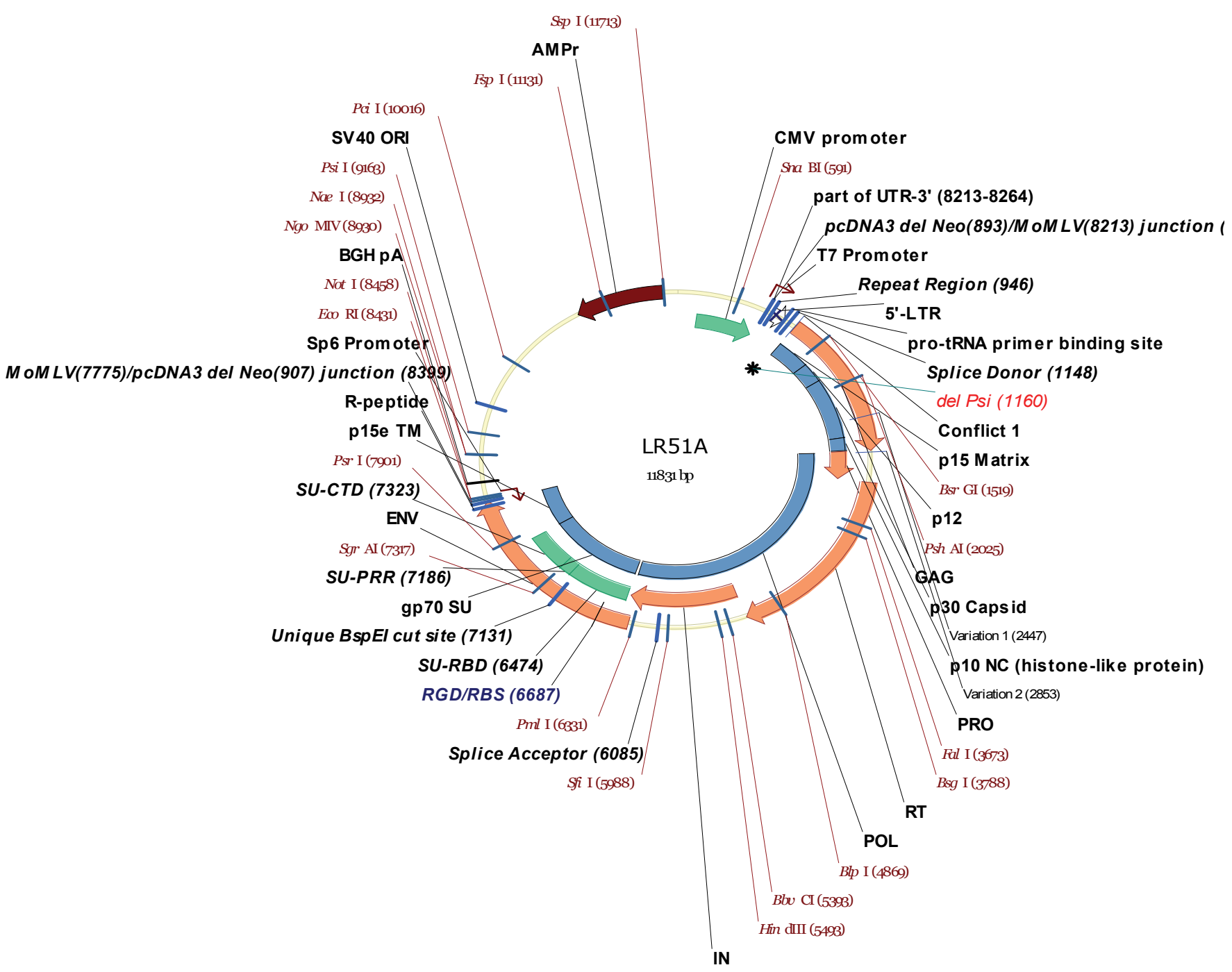

Figure C-46. LR51A. 


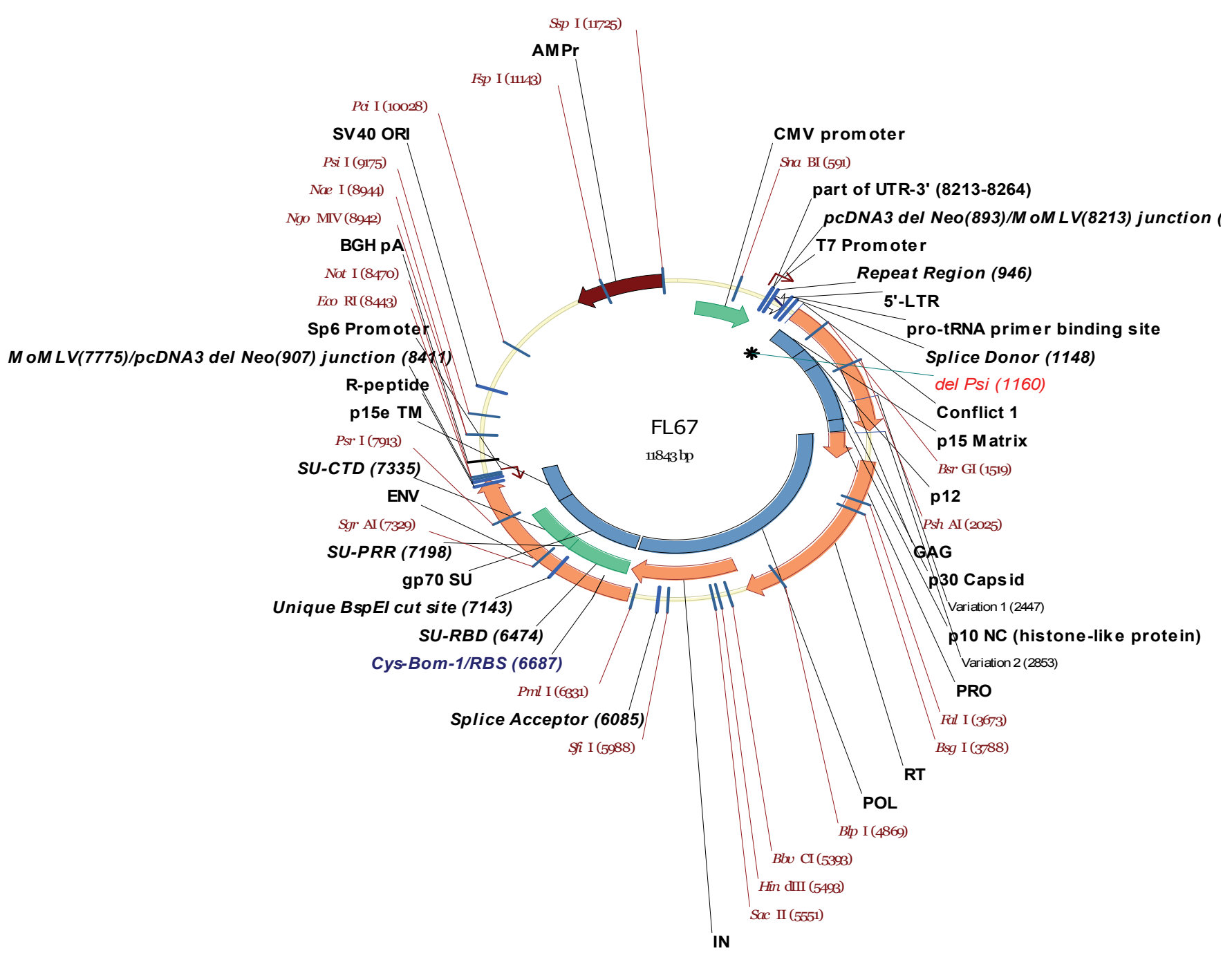

Figure C-47. FL67. 


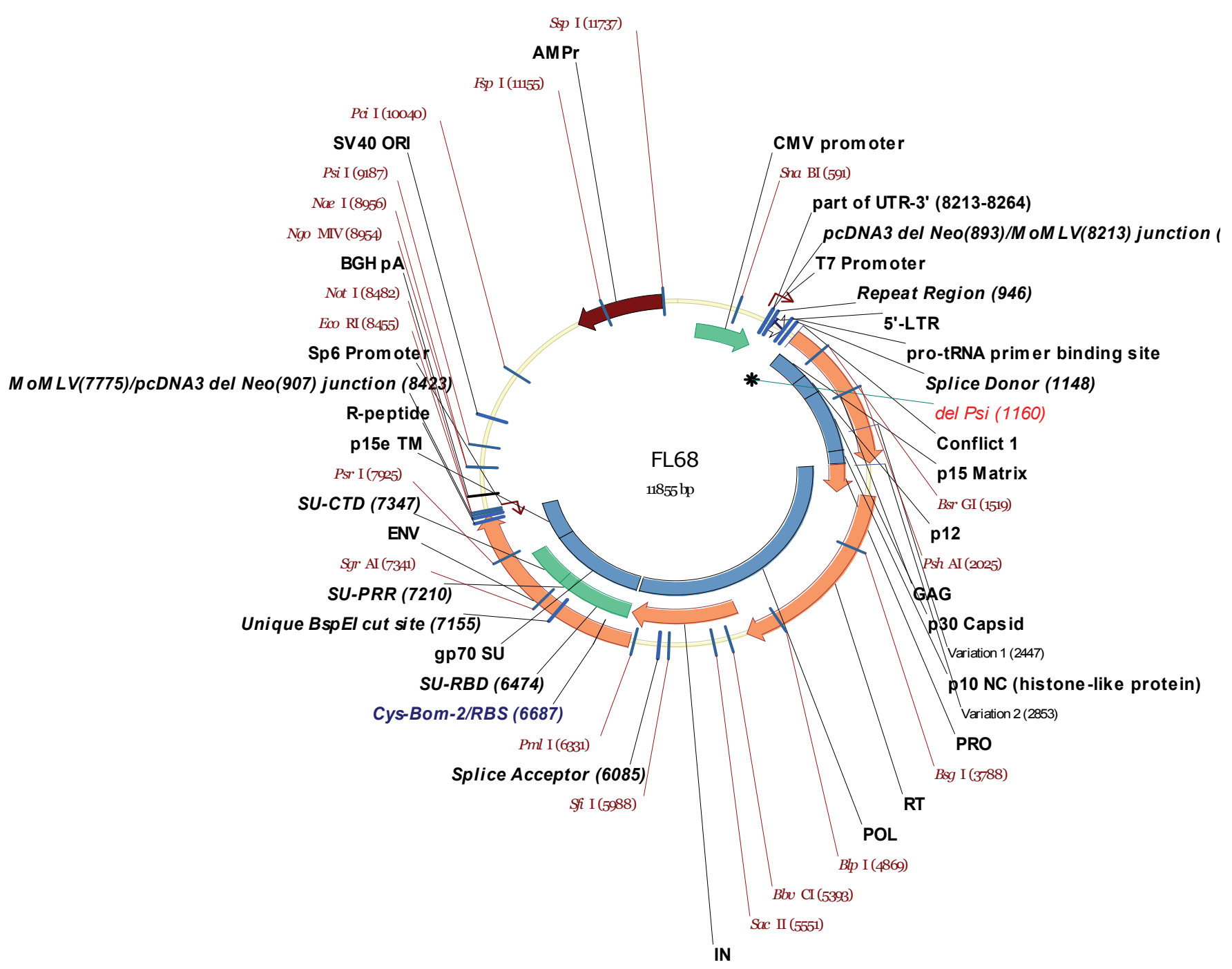

Figure C-48. FL68. 


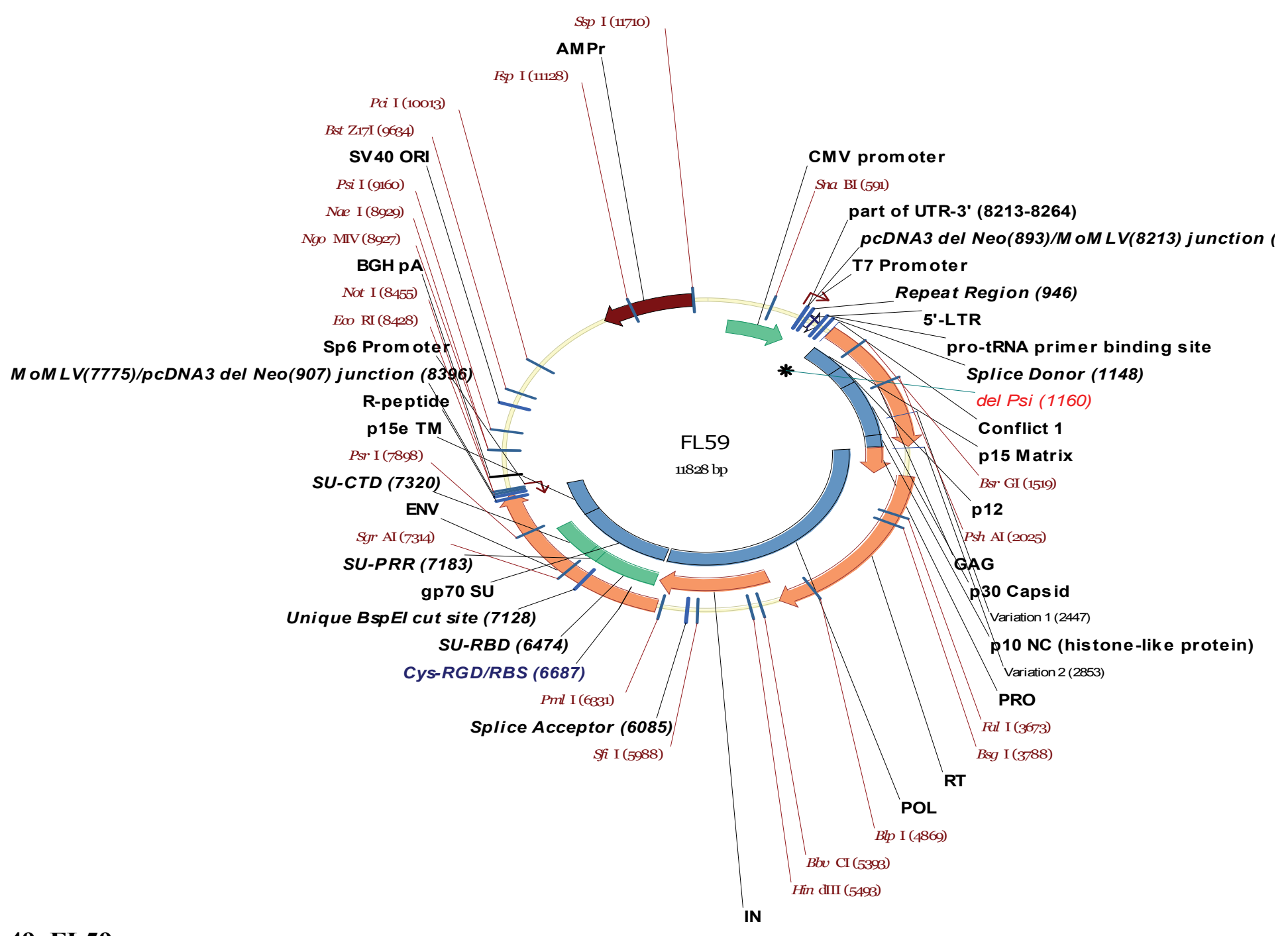

Figure C-49. FL59. 


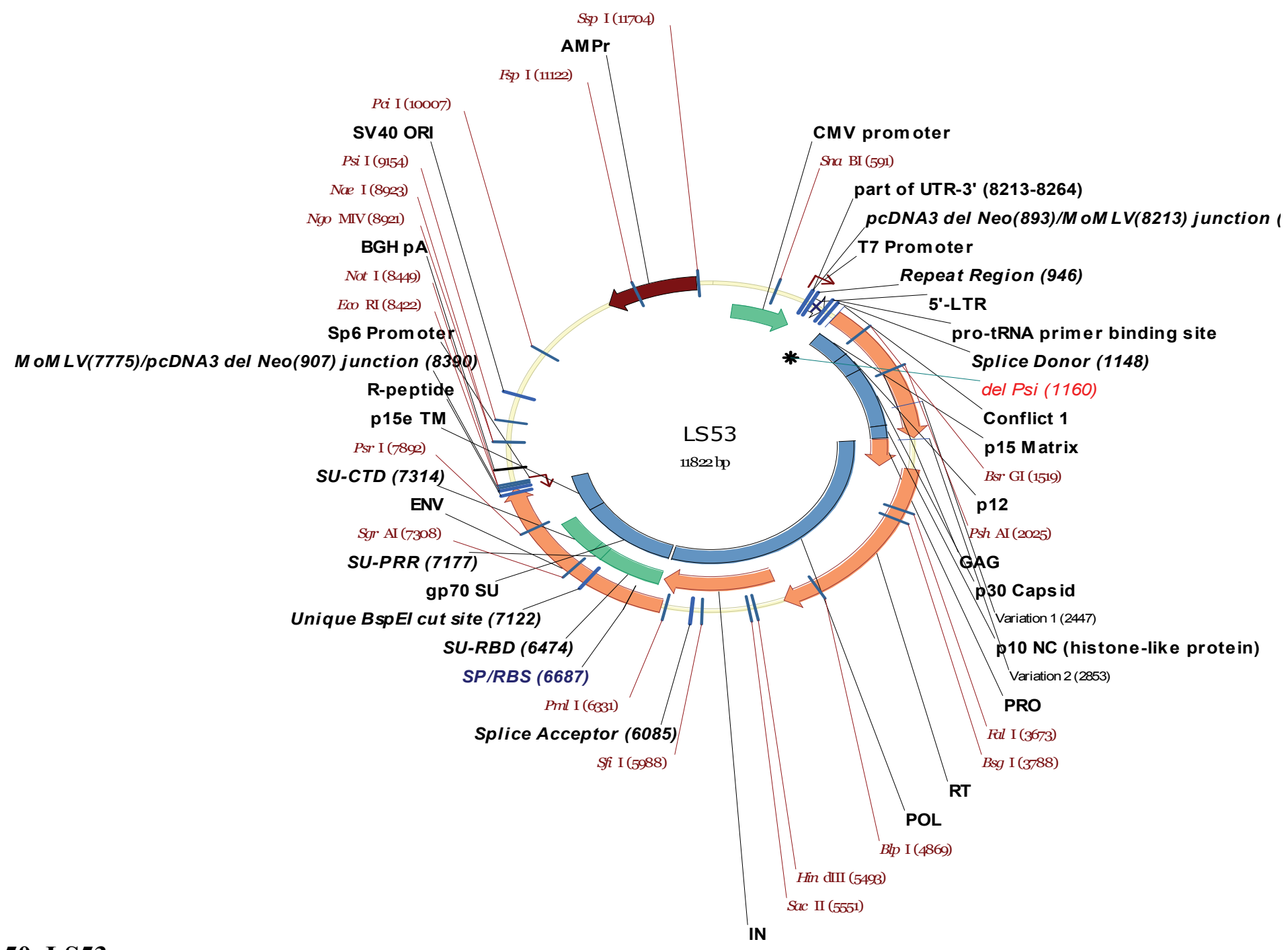

Figure C-50. LS53. 


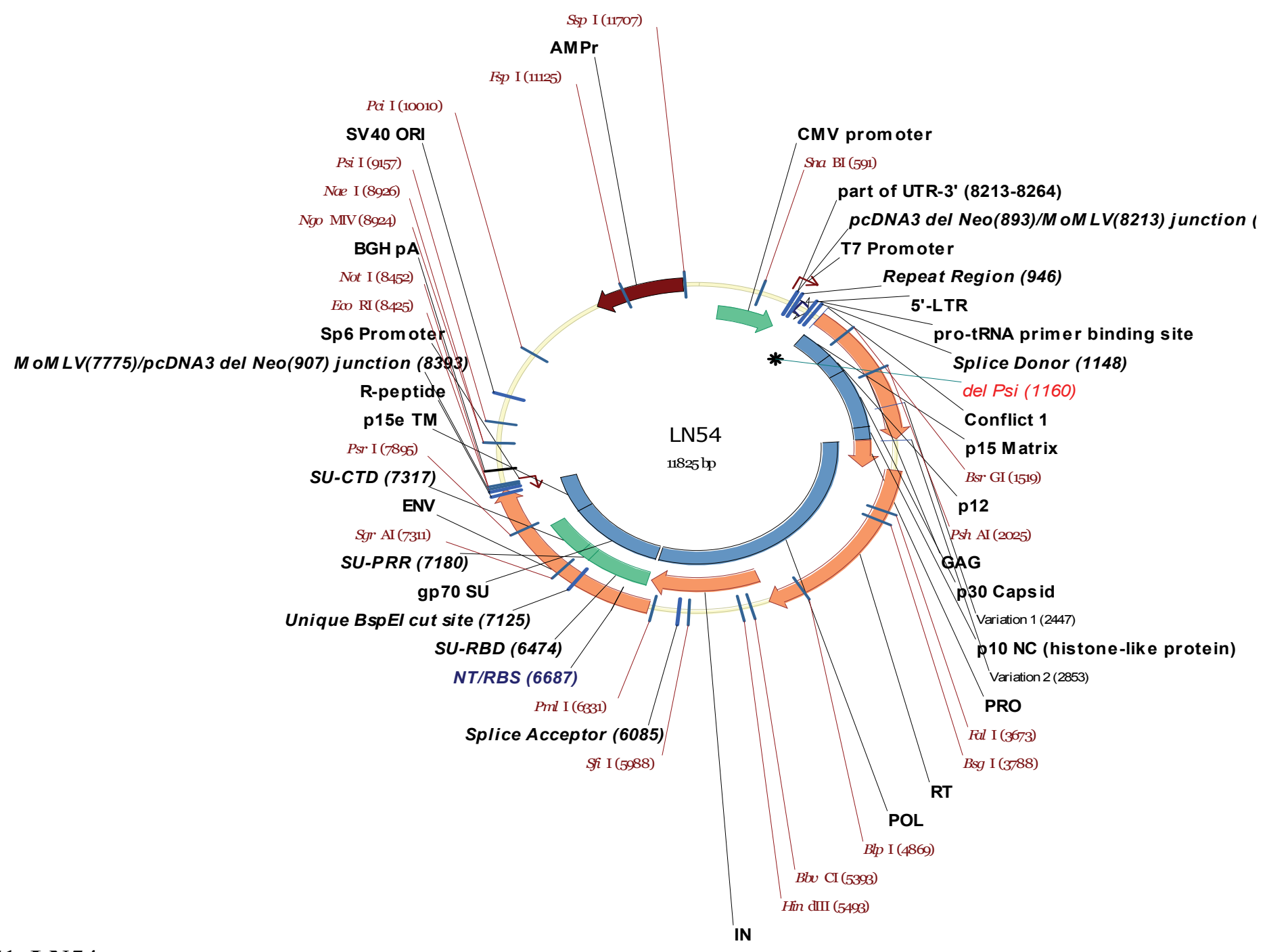

Figure C-51. LN54. 


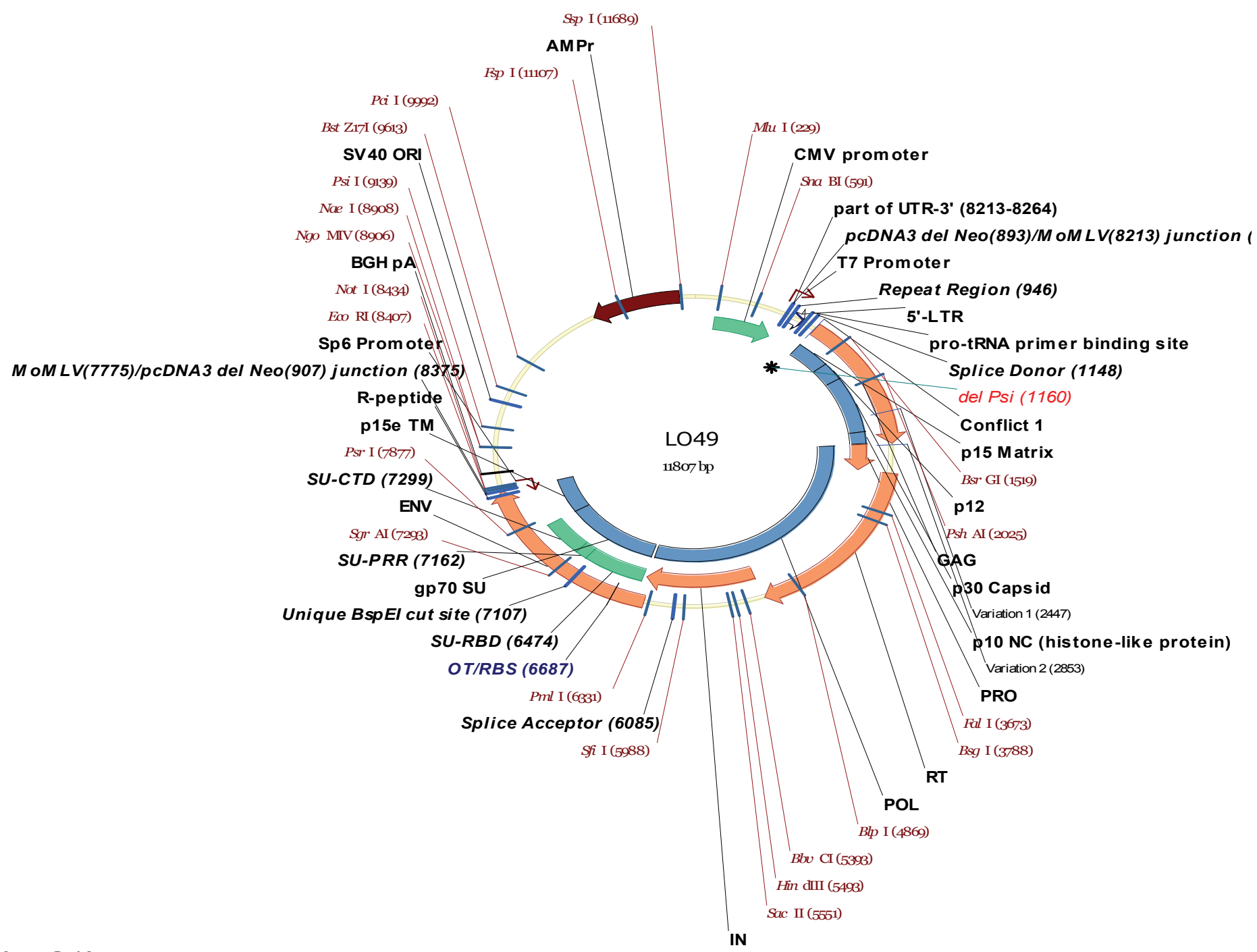

Figure C-52. LO49. 


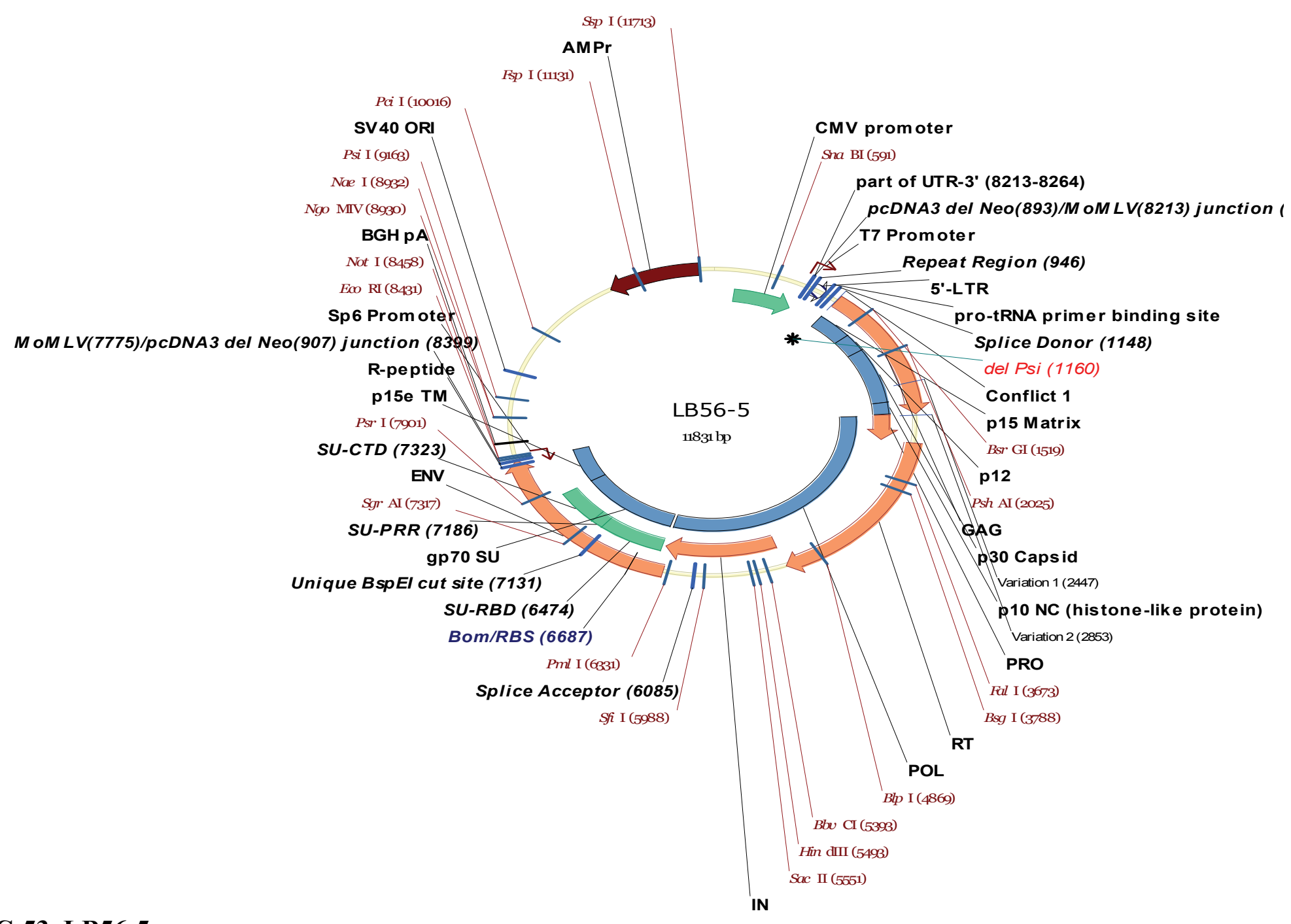

Figure C-53. LB56-5. 


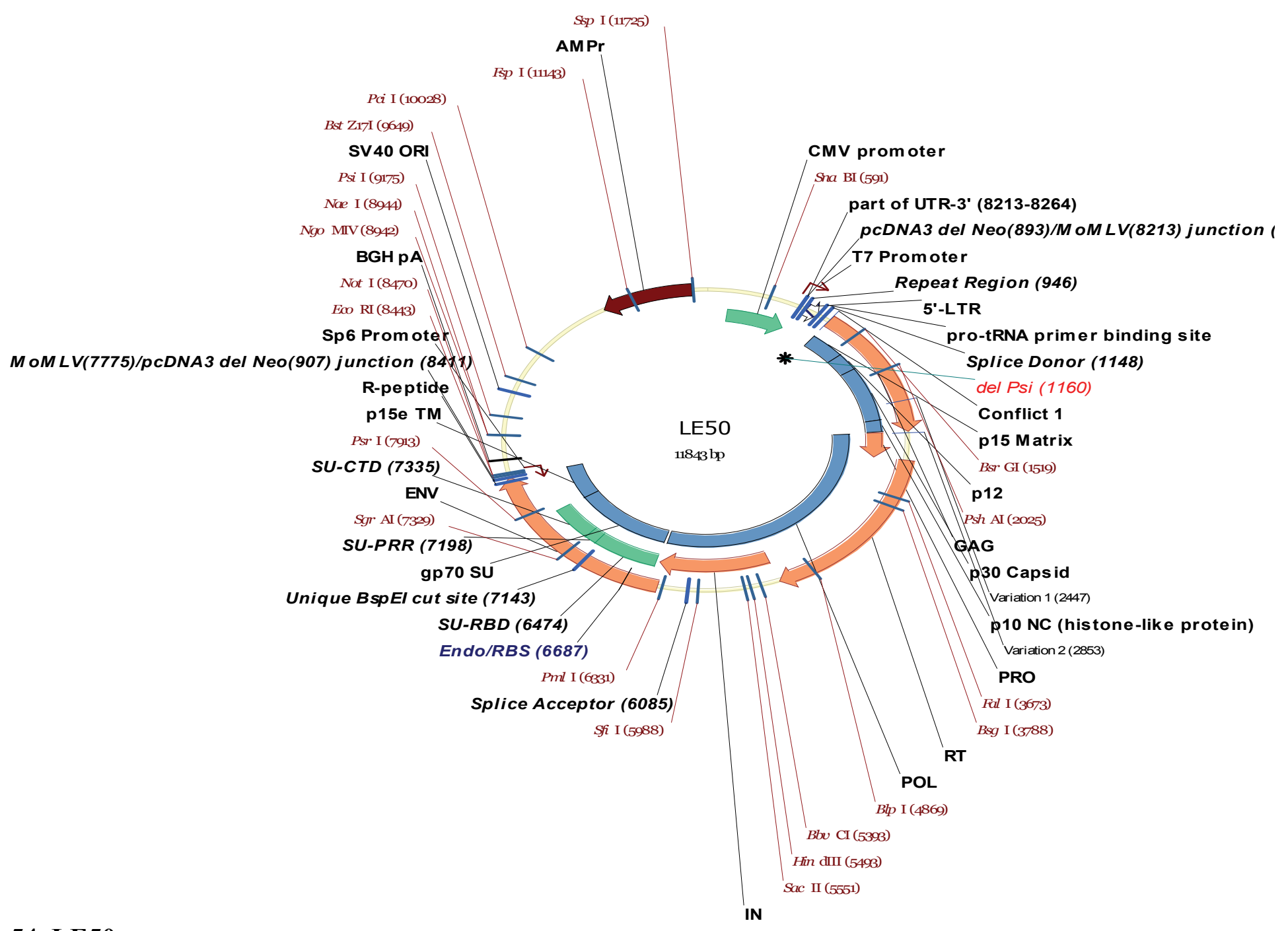

Figure C-54. LE50. 


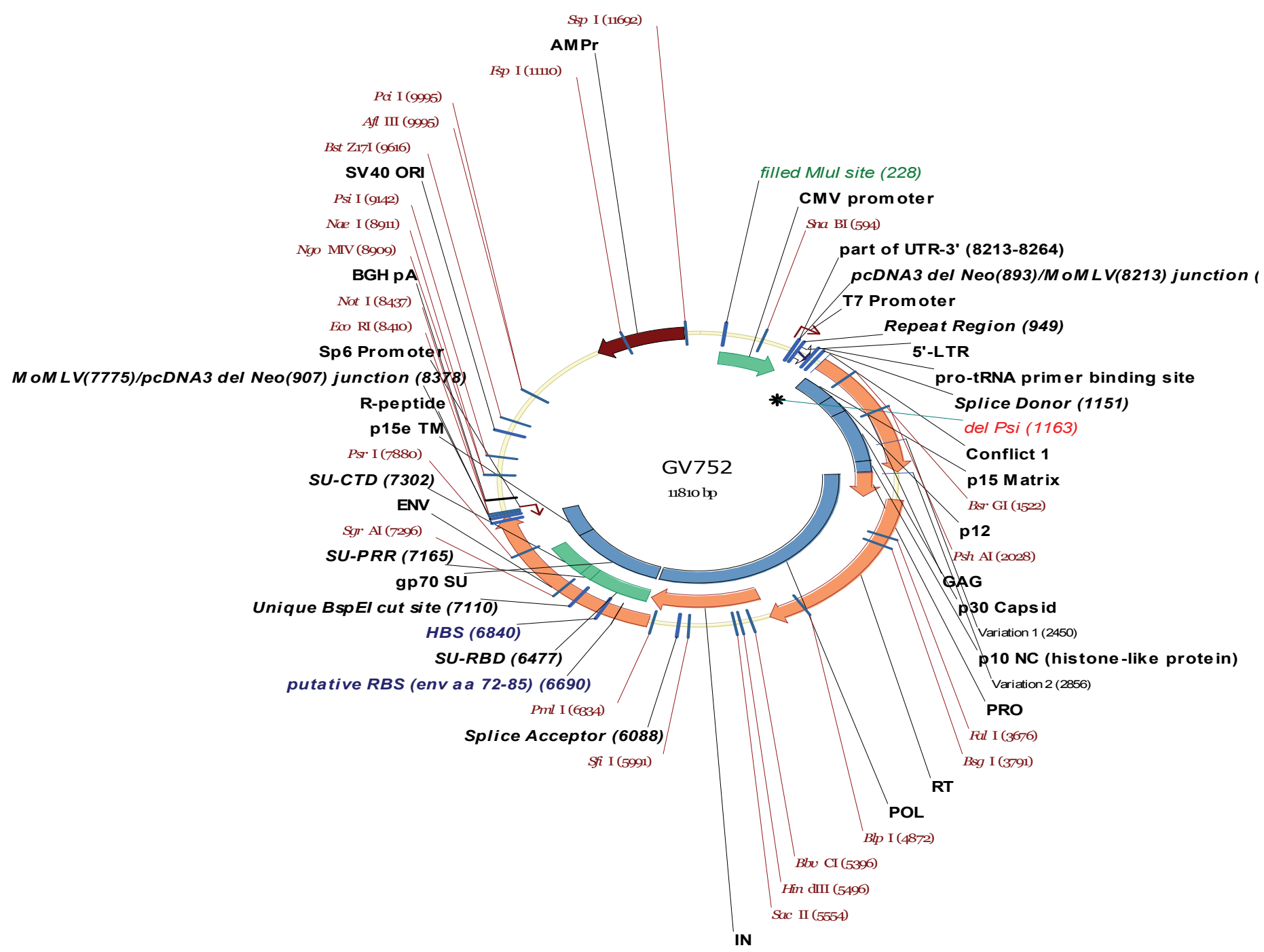

Figure C-55. GV752. 


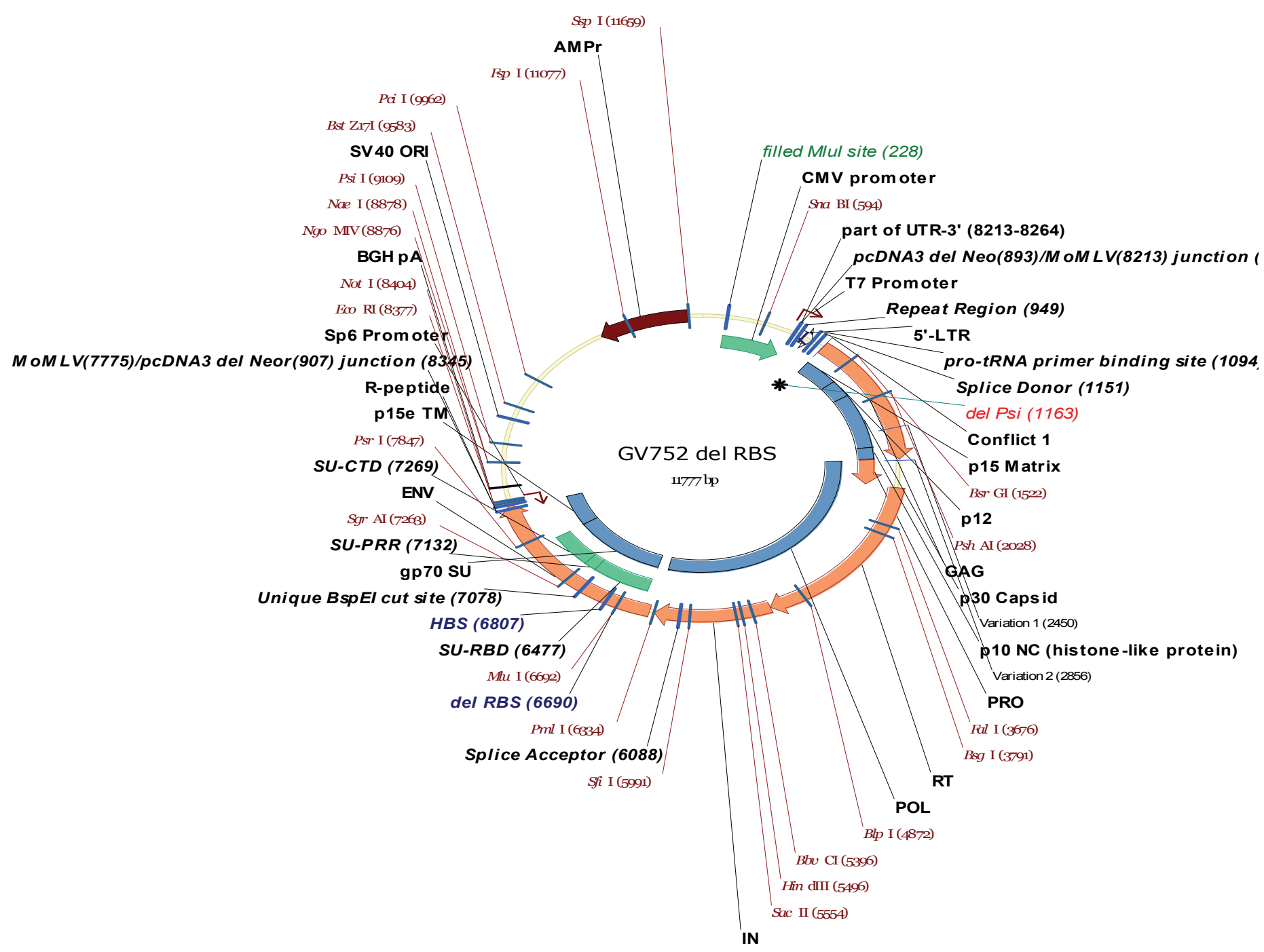

Figure C-56. GV752_delRBS. 


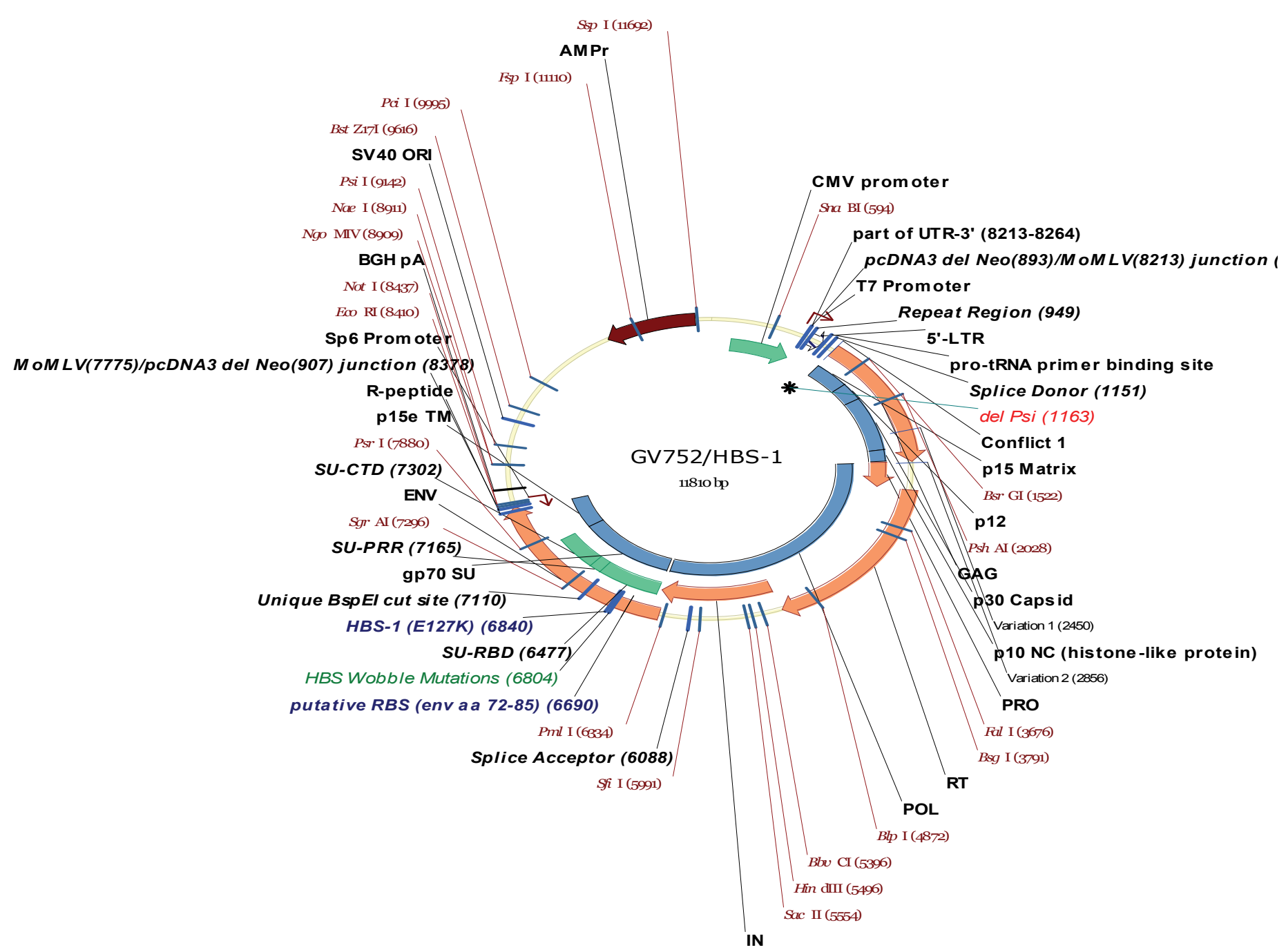

Figure C-57. GV752/HBS-1. 


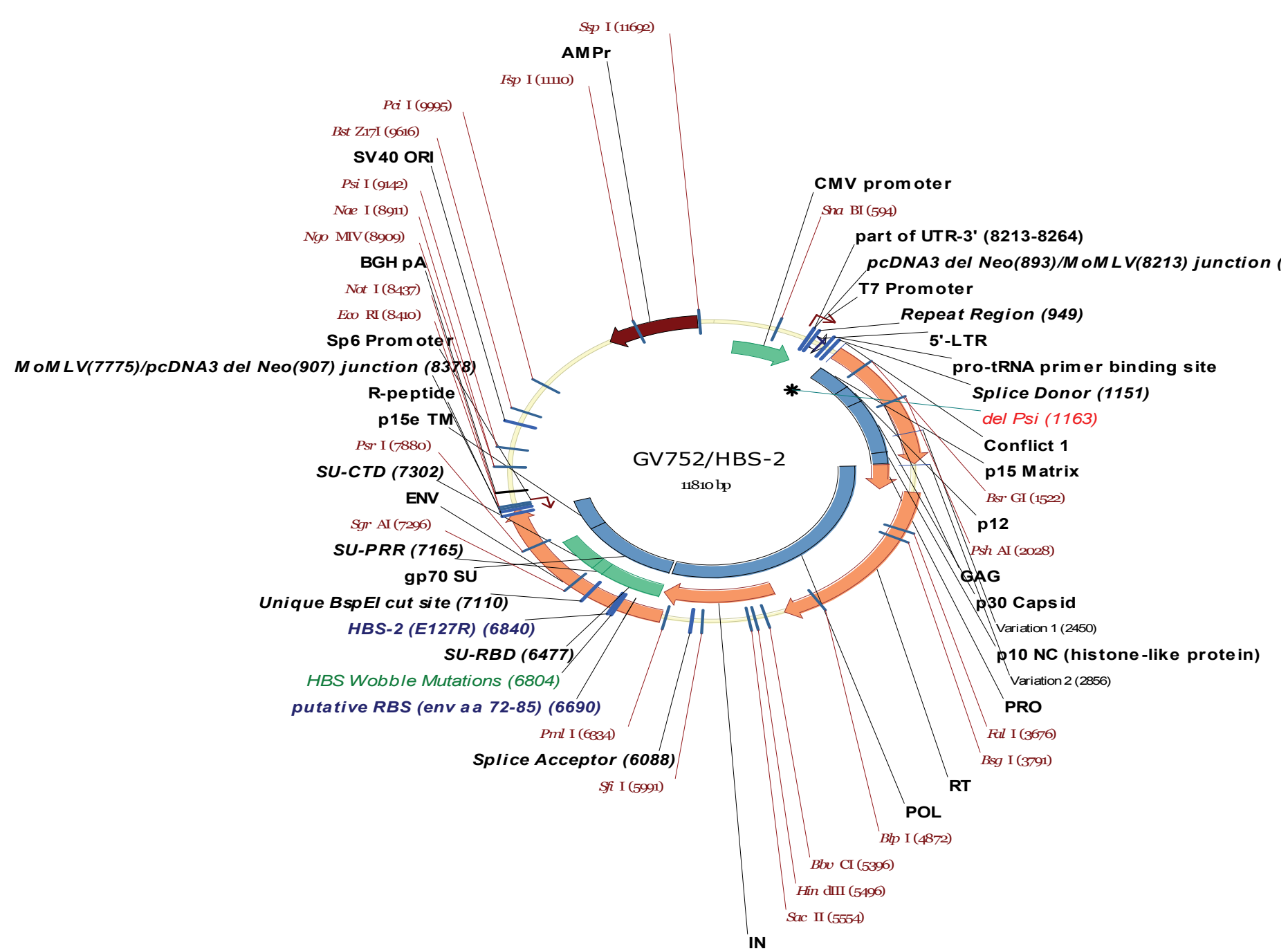

Figure C-58. GV752/HBS-2. 


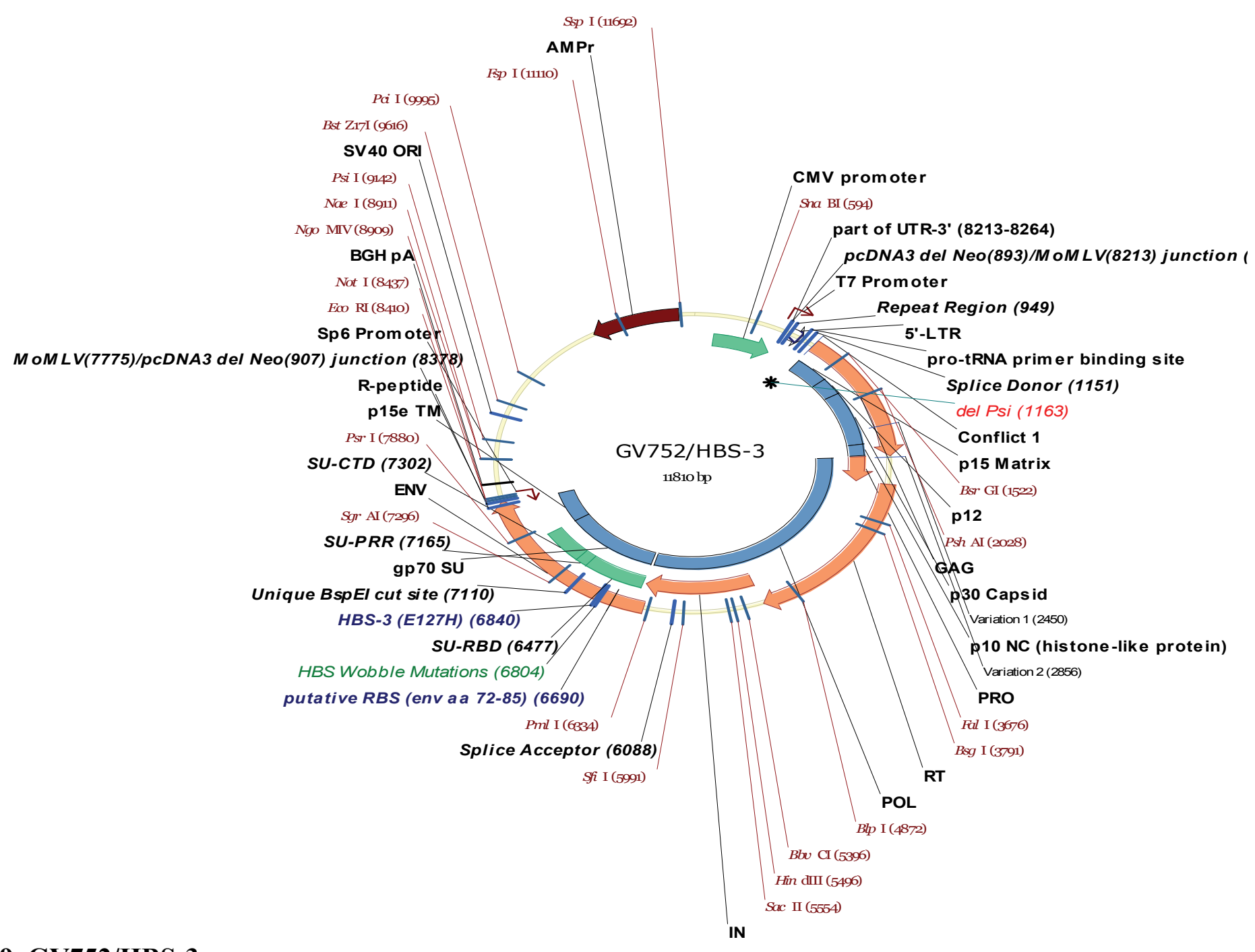

Figure C-59. GV752/HBS-3. 


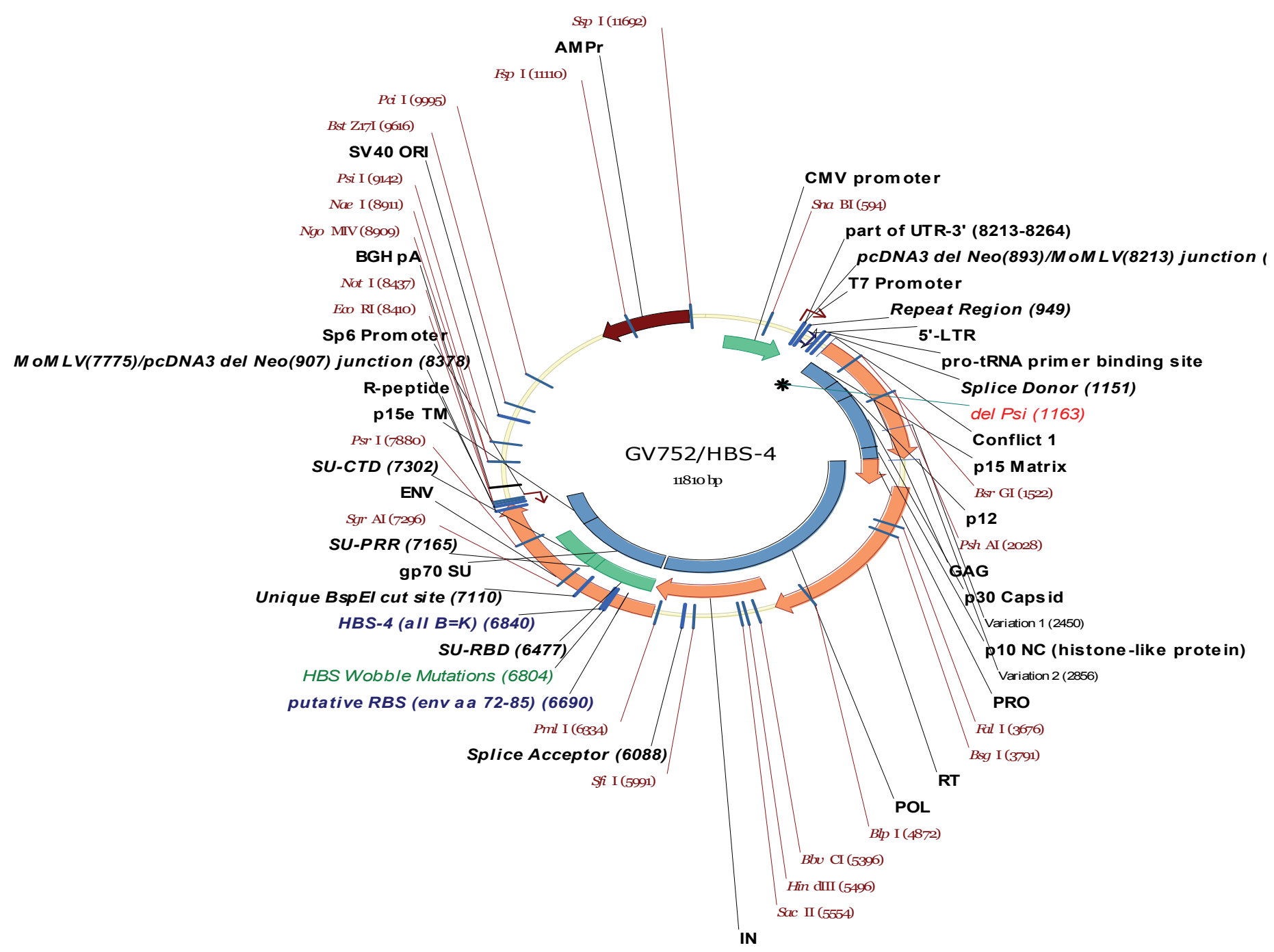

Figure C-60. GV752/HBS-4. 


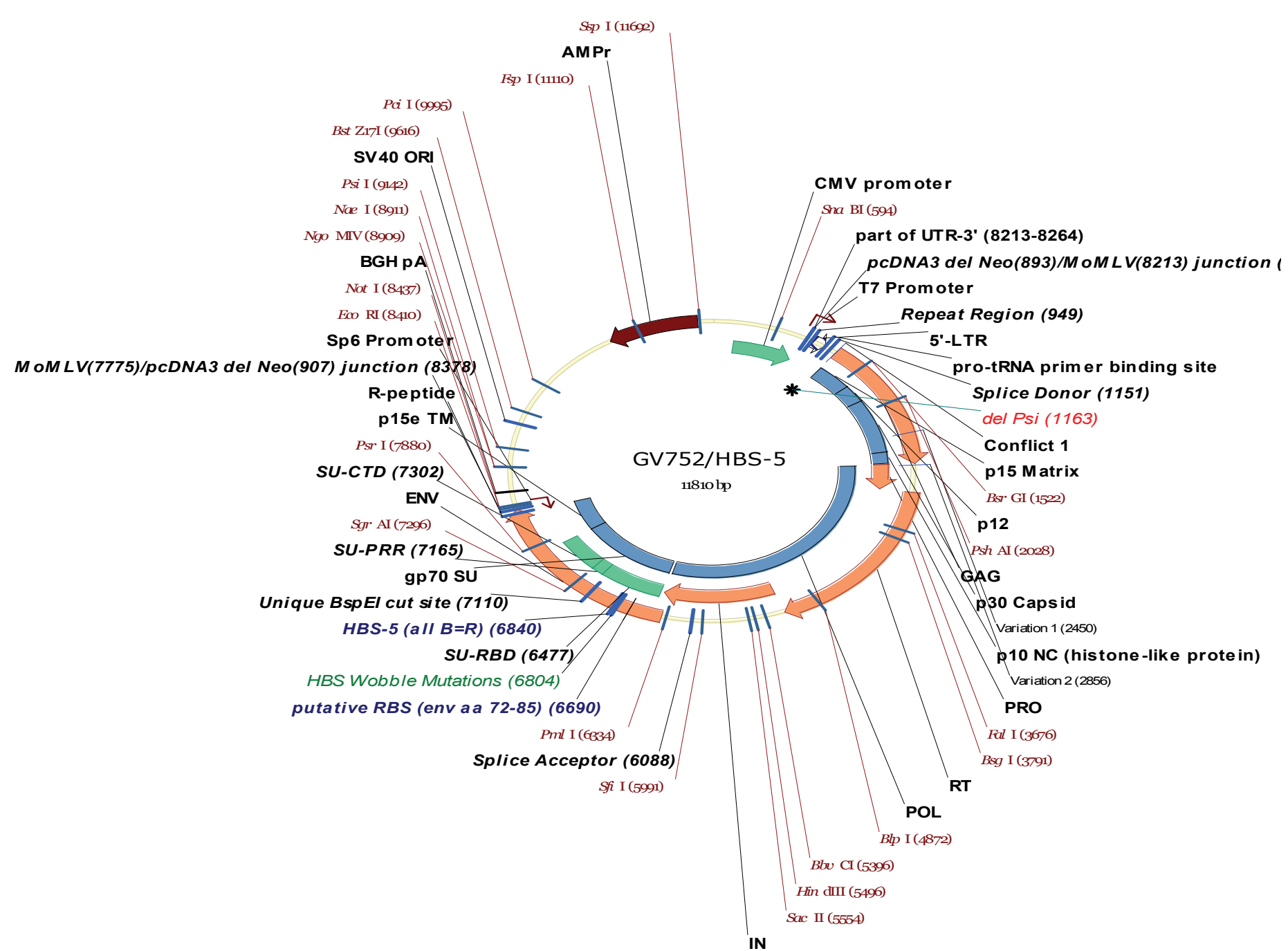

Figure C-61. GV752/HBS-5. 


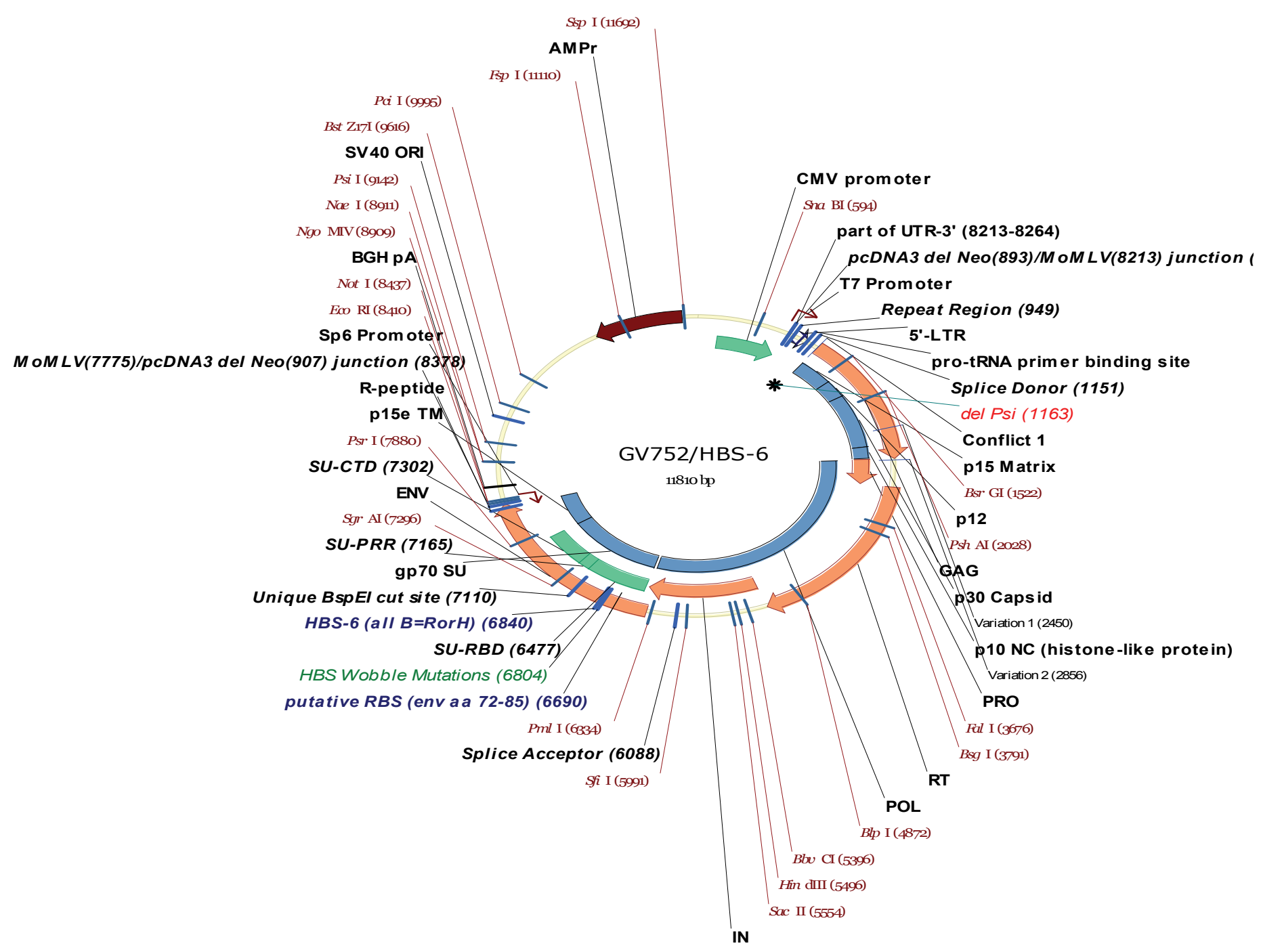

Figure C-62. GV752/HBS-6. 


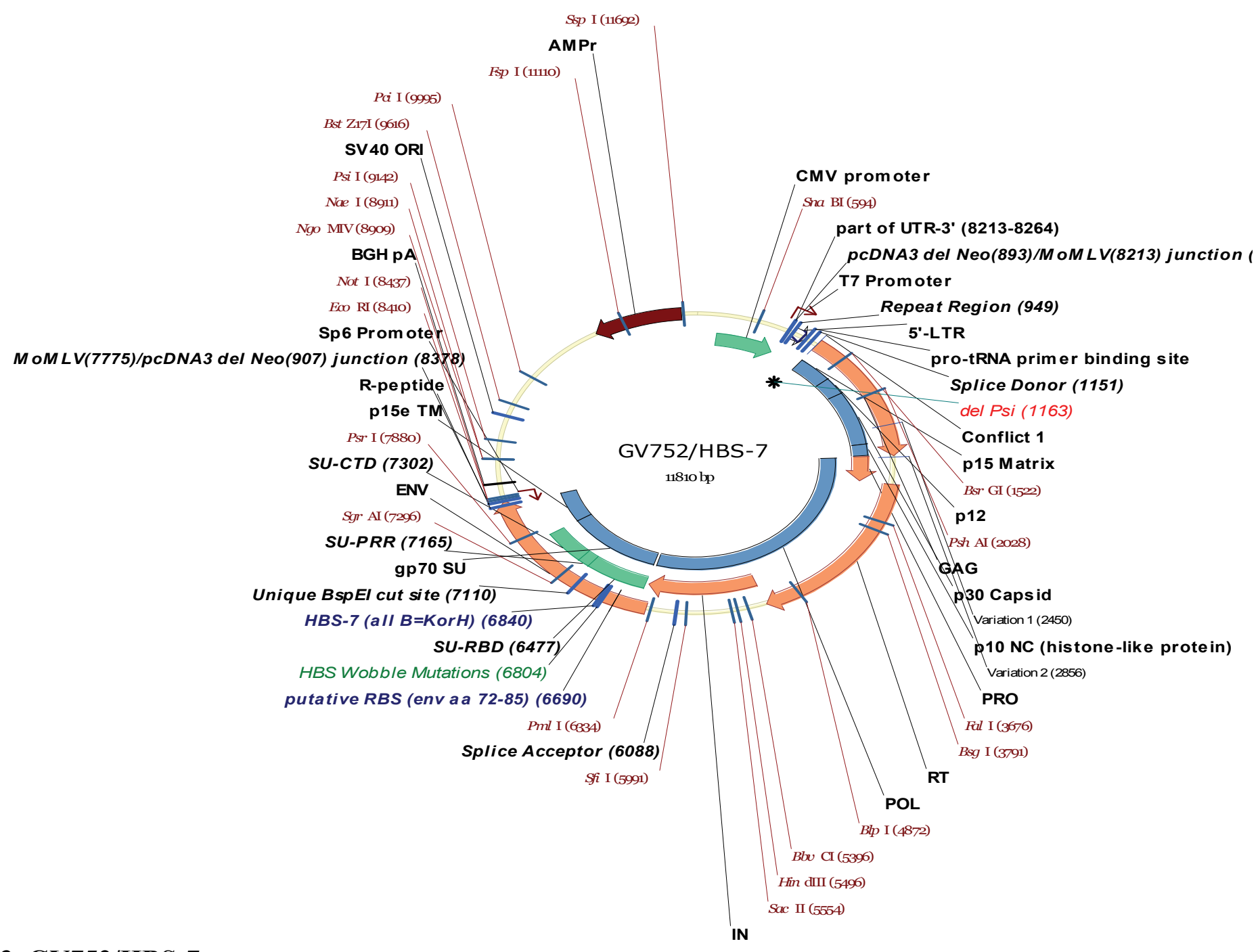

Figure C-63. GV752/HBS-7. 


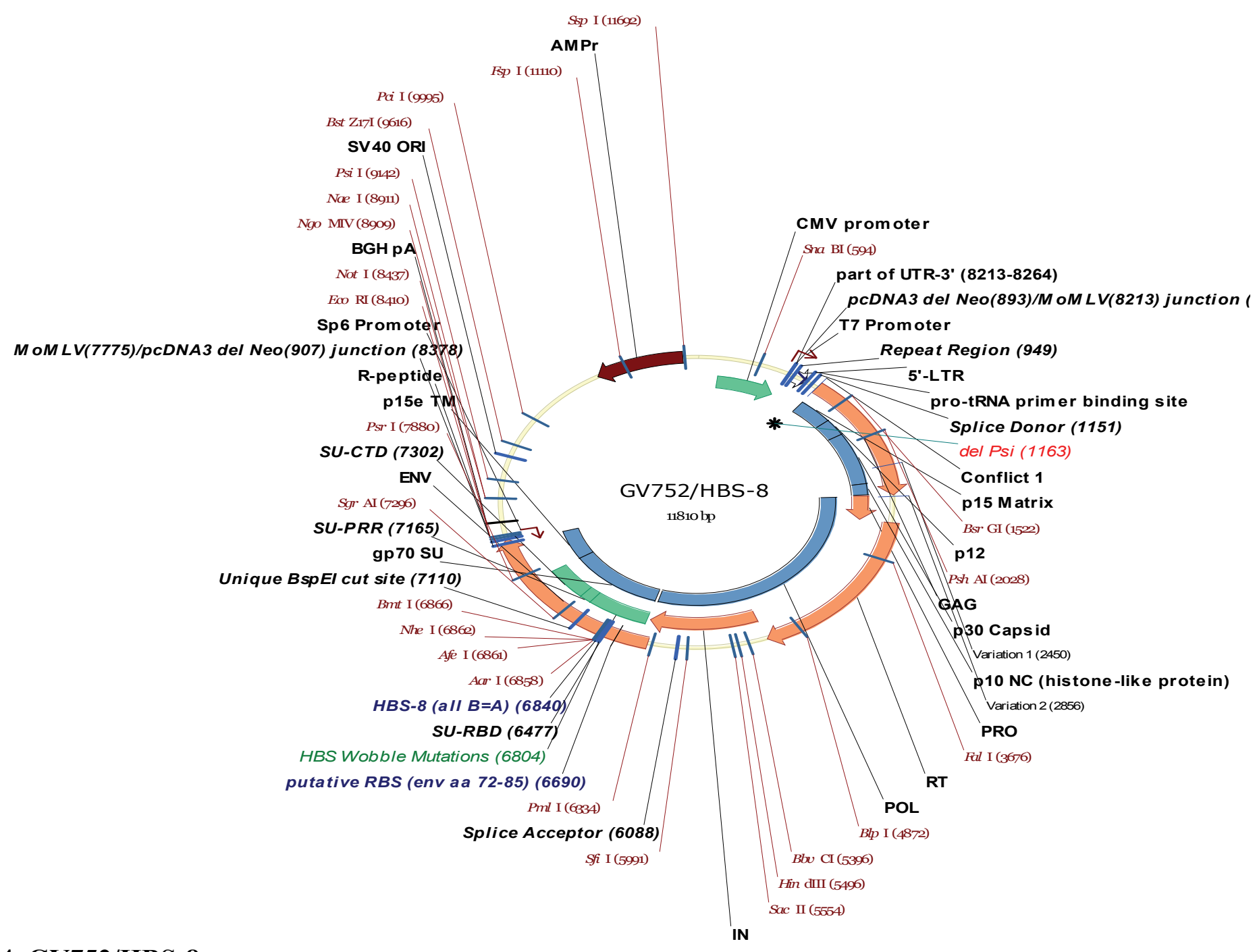

Figure C-64. GV752/HBS-8. 


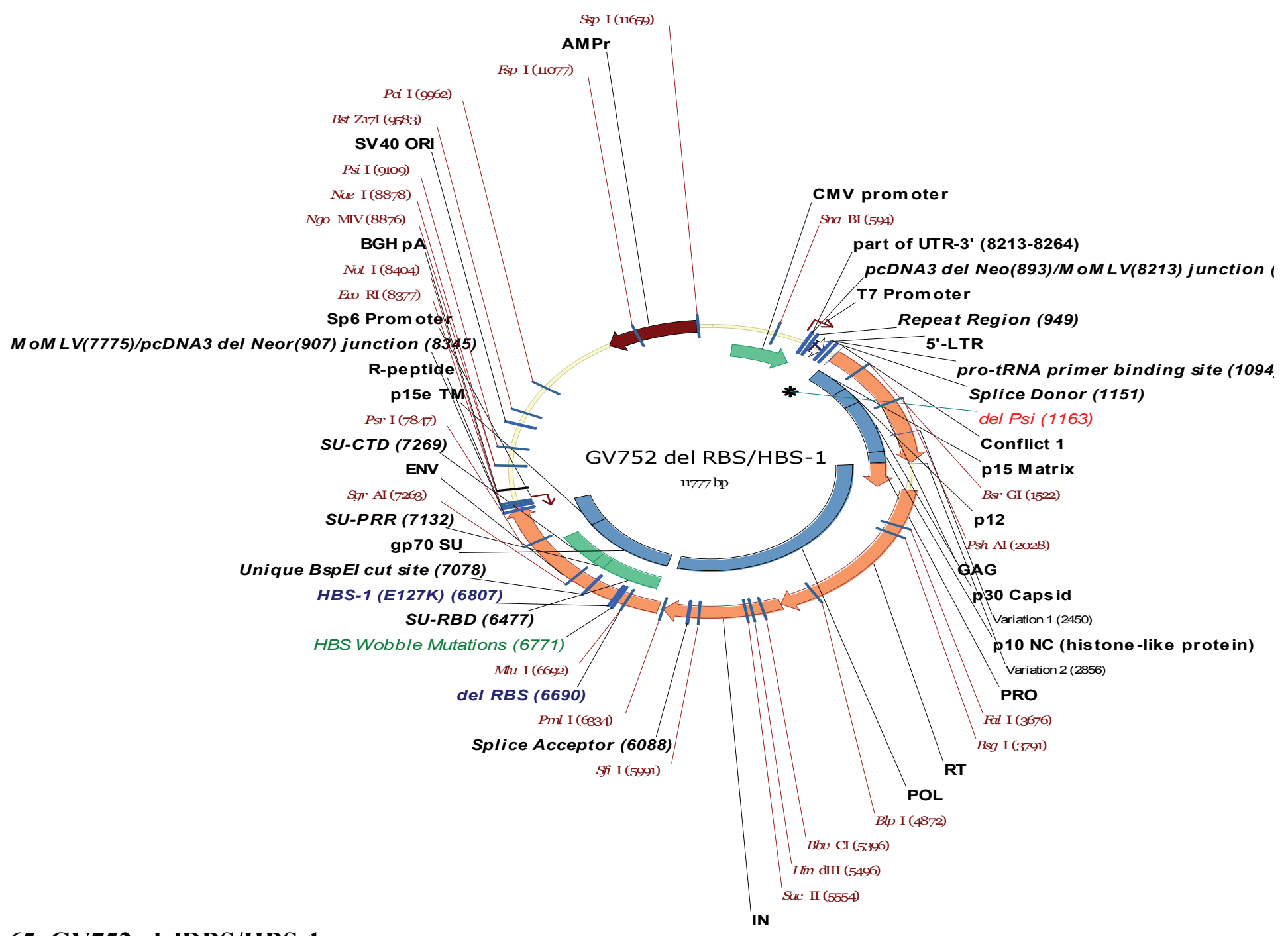

Figure C-65. GV752_delRBS/HBS-1. 


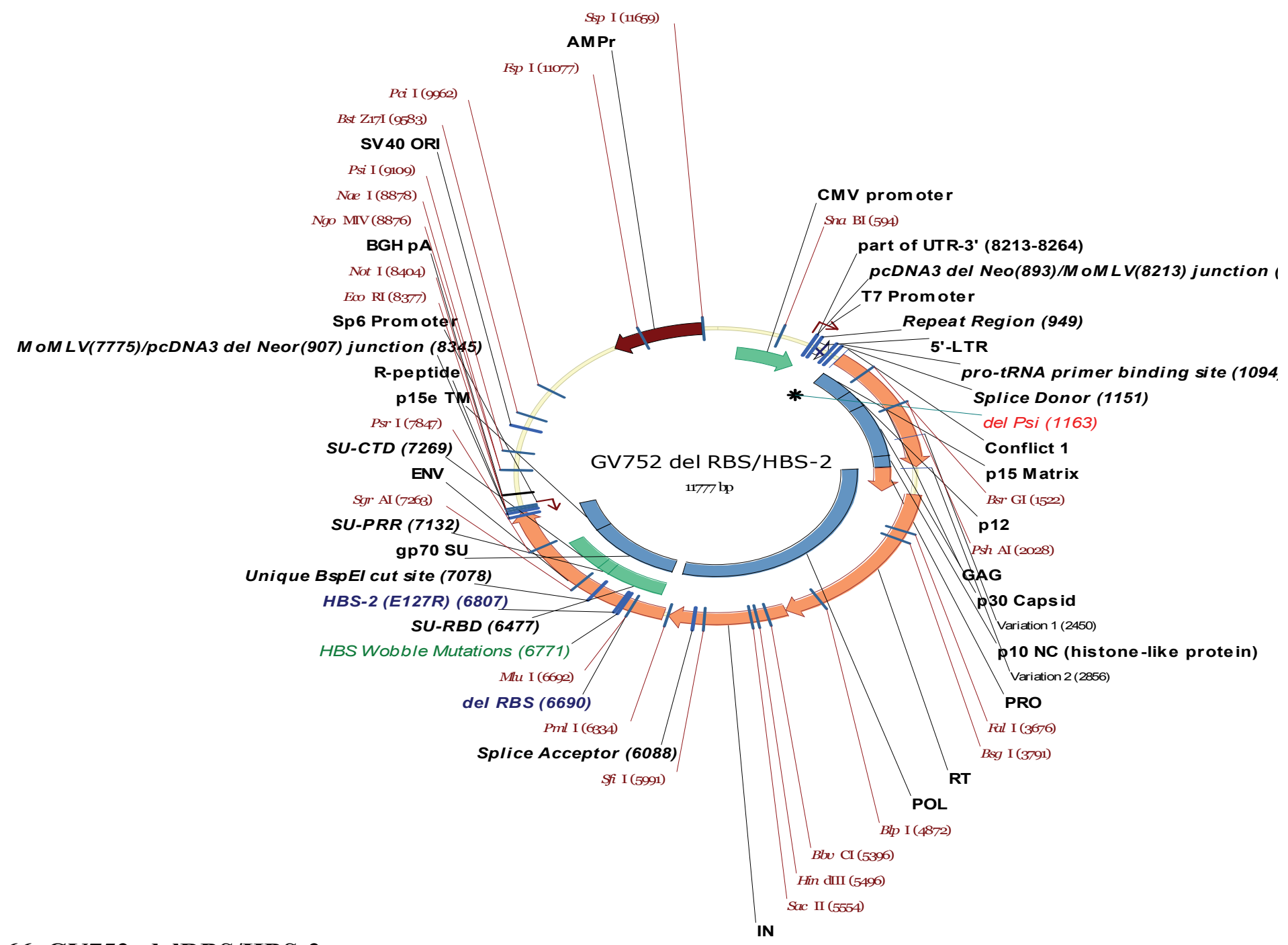

Figure C-66. GV752_delRBS/HBS-2. 


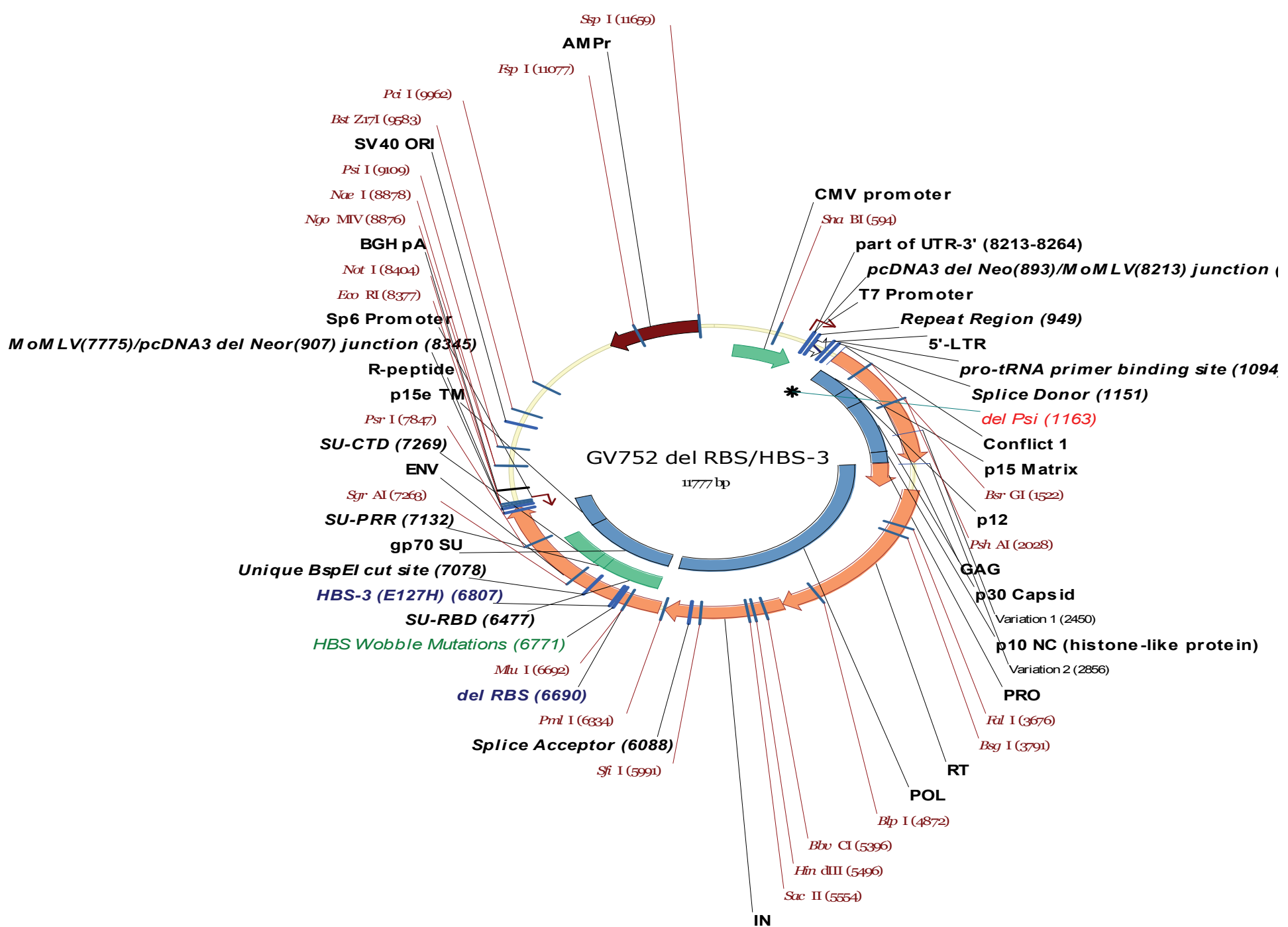

Figure C-67. GV752_delRBS/HBS-3. 


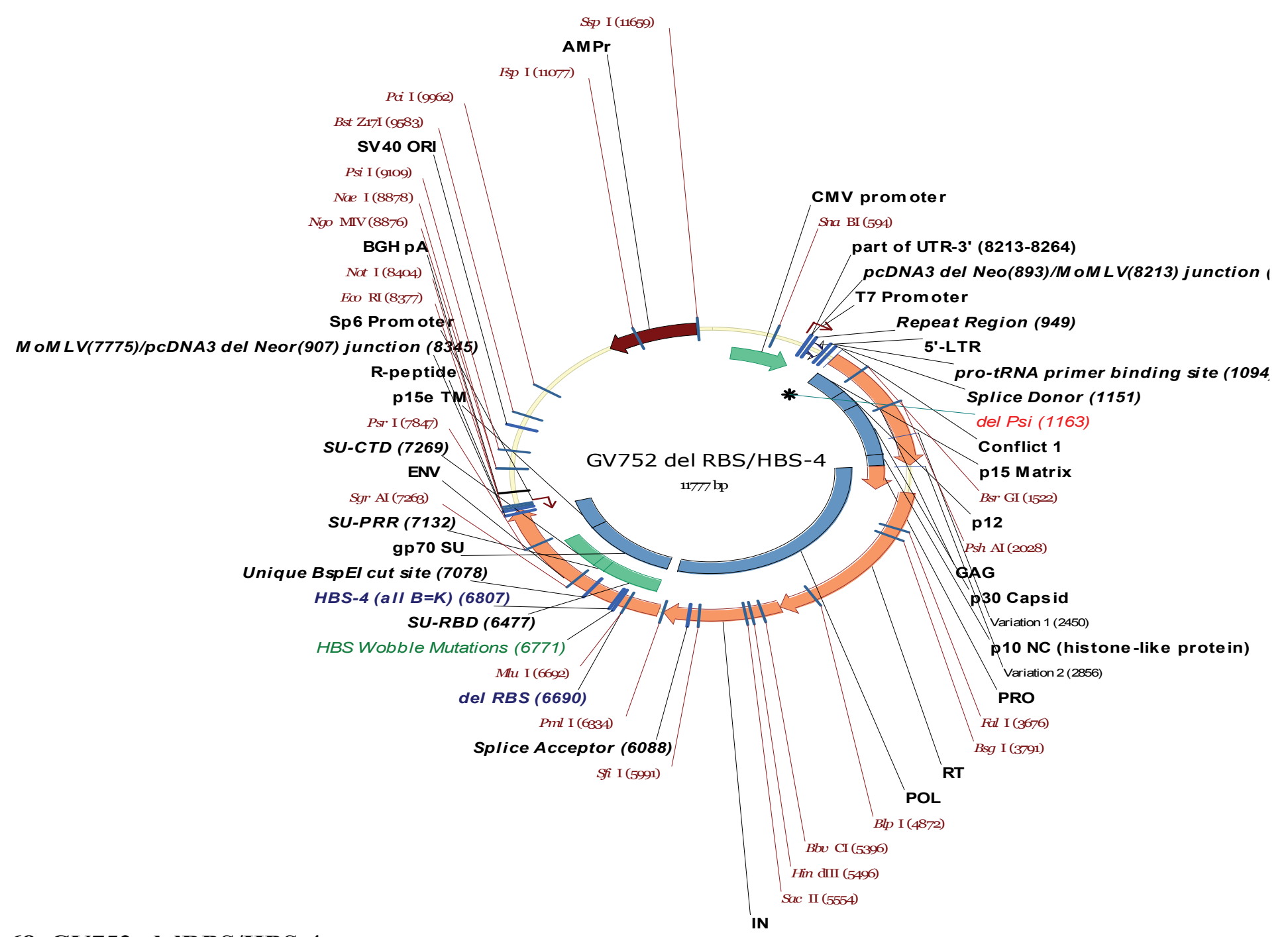

Figure C-68. GV752_delRBS/HBS-4. 


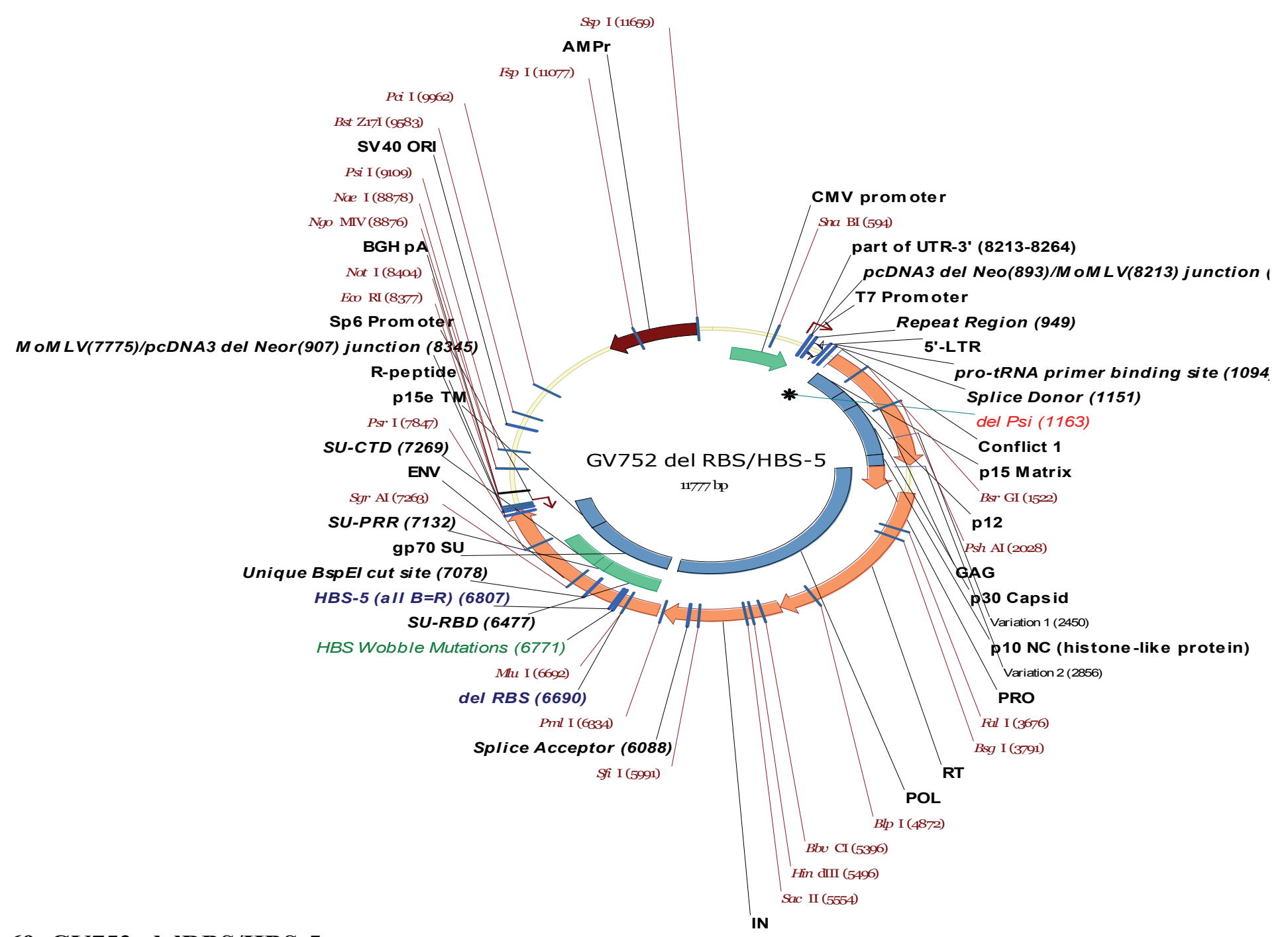

Figure C-69. GV752_delRBS/HBS-5. 


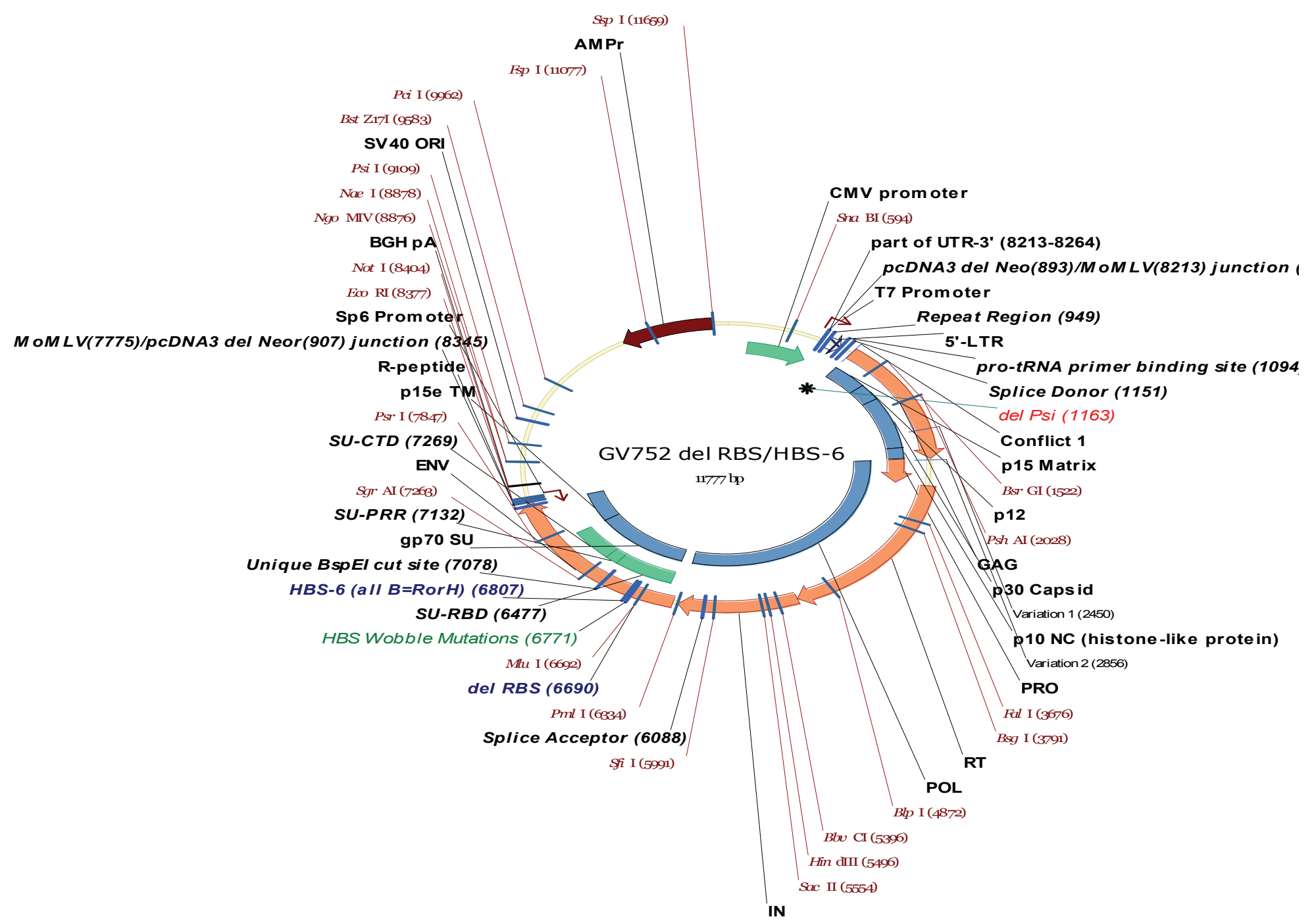

Figure C-70. GV752_delRBS/HBS-6. 


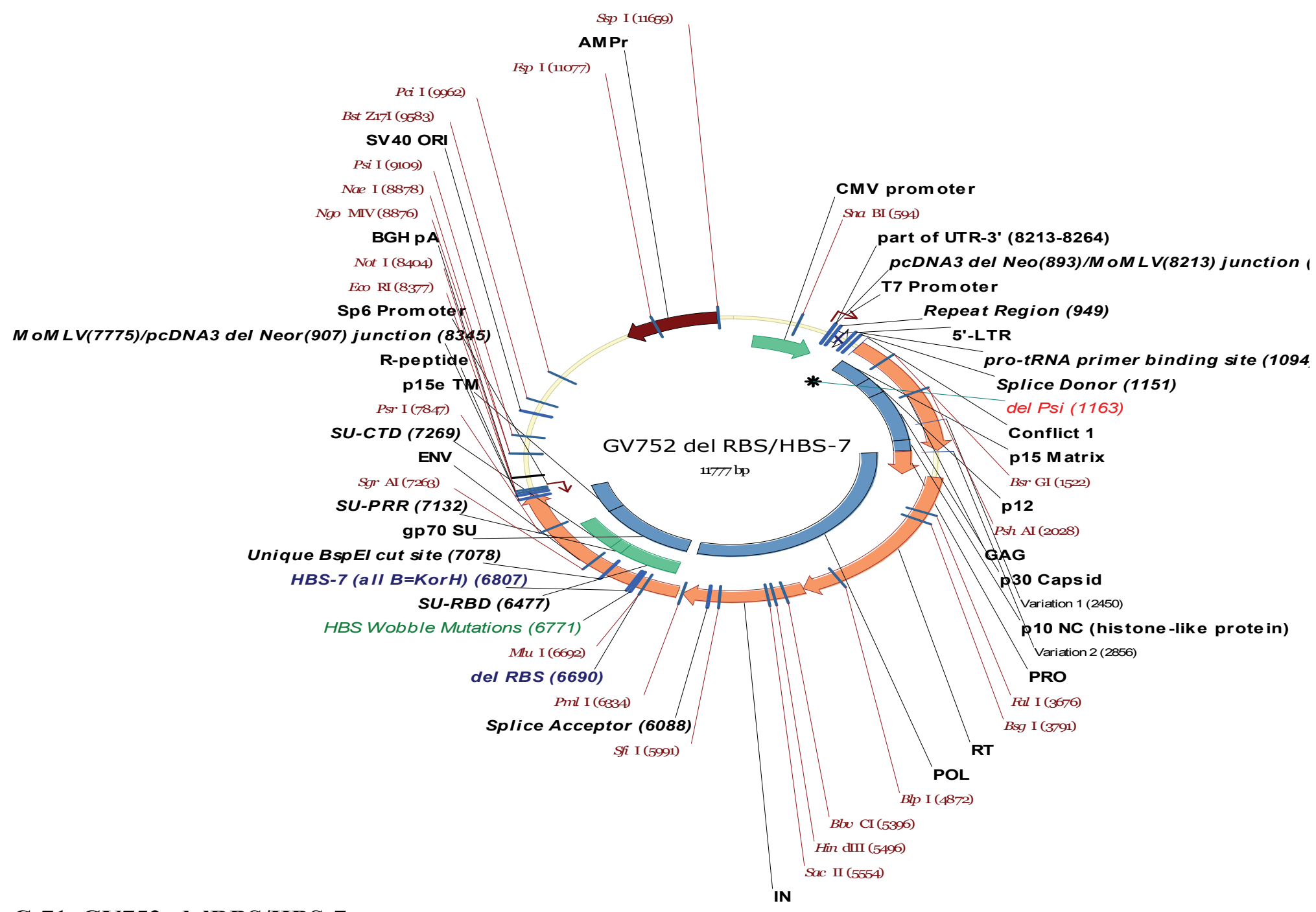

Figure C-71. GV752_delRBS/HBS-7. 


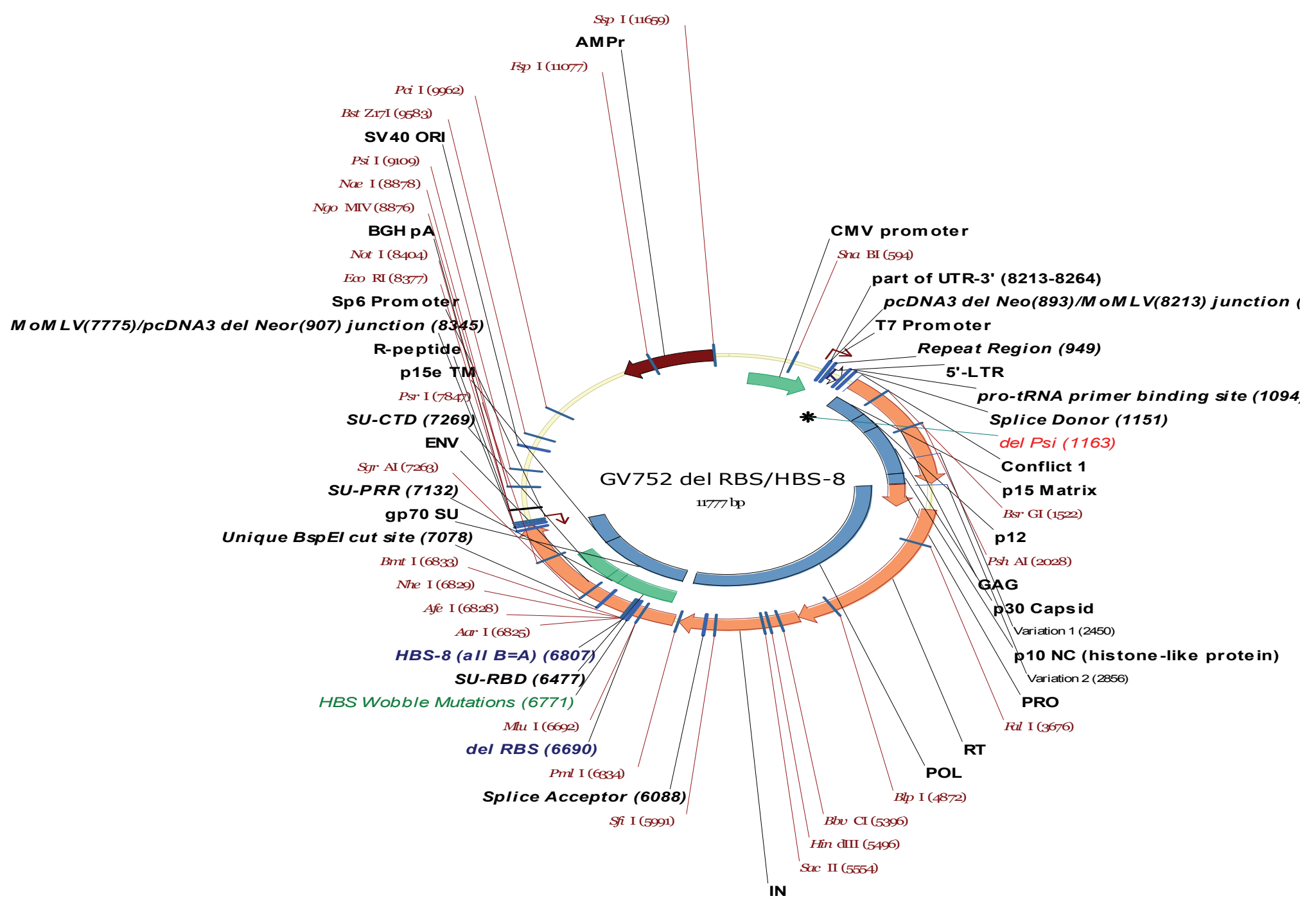

Figure C-72. GV752_delRBS/HBS-8. 
Geneva M. Vasser was born in 1973 in West Palm Beach, Florida. She graduated from Santaluces Community High School in 1991 and joined the U.S. Navy shortly after that time. After a successful seven year tour as an avionics technician, she left the military to pursue a career in science. She attended the University of Wyoming, earning her Bachelor of Science degree in Molecular Biology in 2004 and was accepted into the University of Tennessee College of Graduate Health Sciences Integrated Program in Biomedical Sciences the same year. She successfully defended her thesis and earned her Master of Science degree in April 2008. Geneva and her husband, Stephen, currently reside in Biloxi, MS. 